
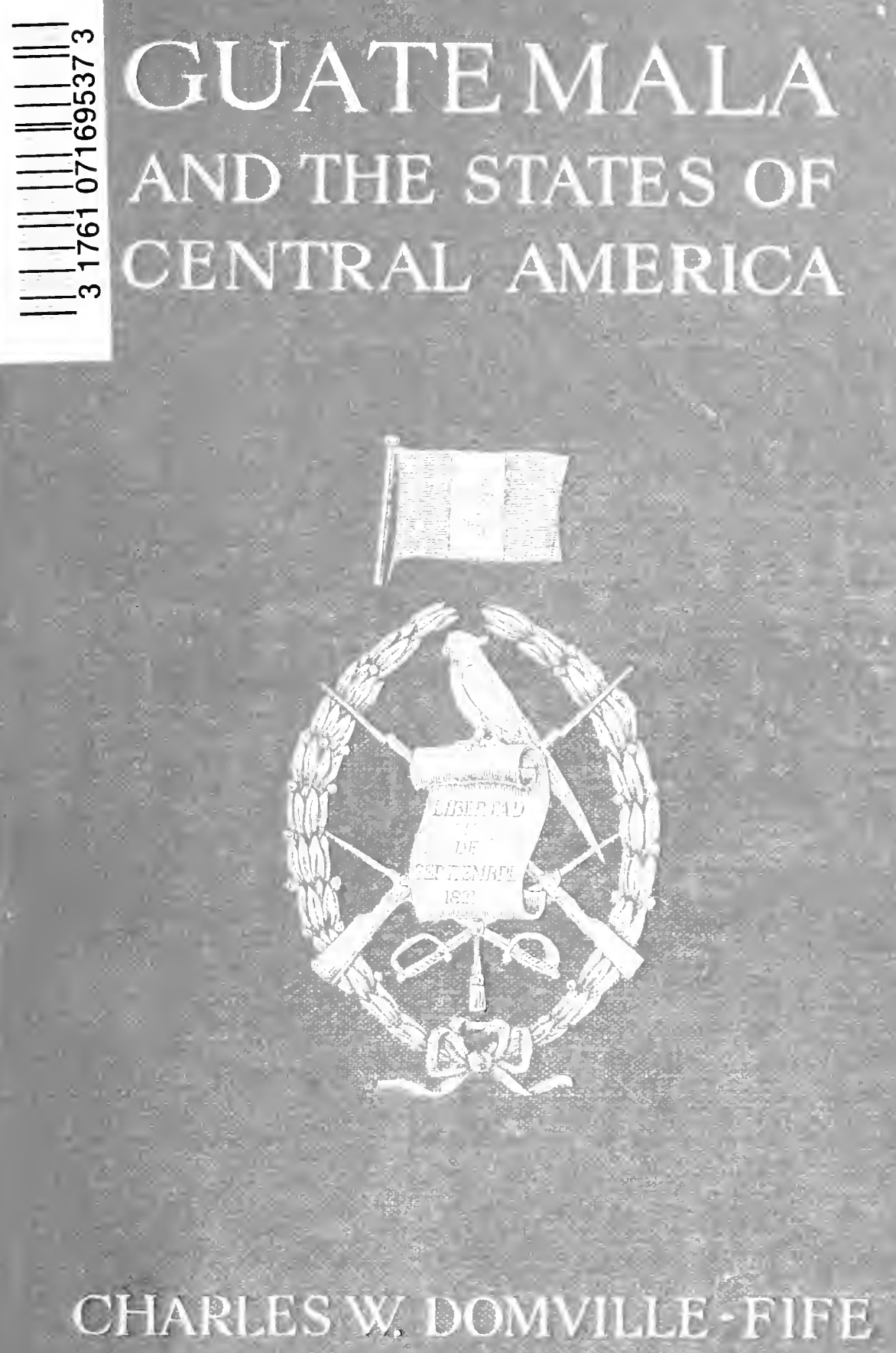


\section{Digitized by the Internet Archive in 2010 with funding from University of Toronto}


GUATEMALA 



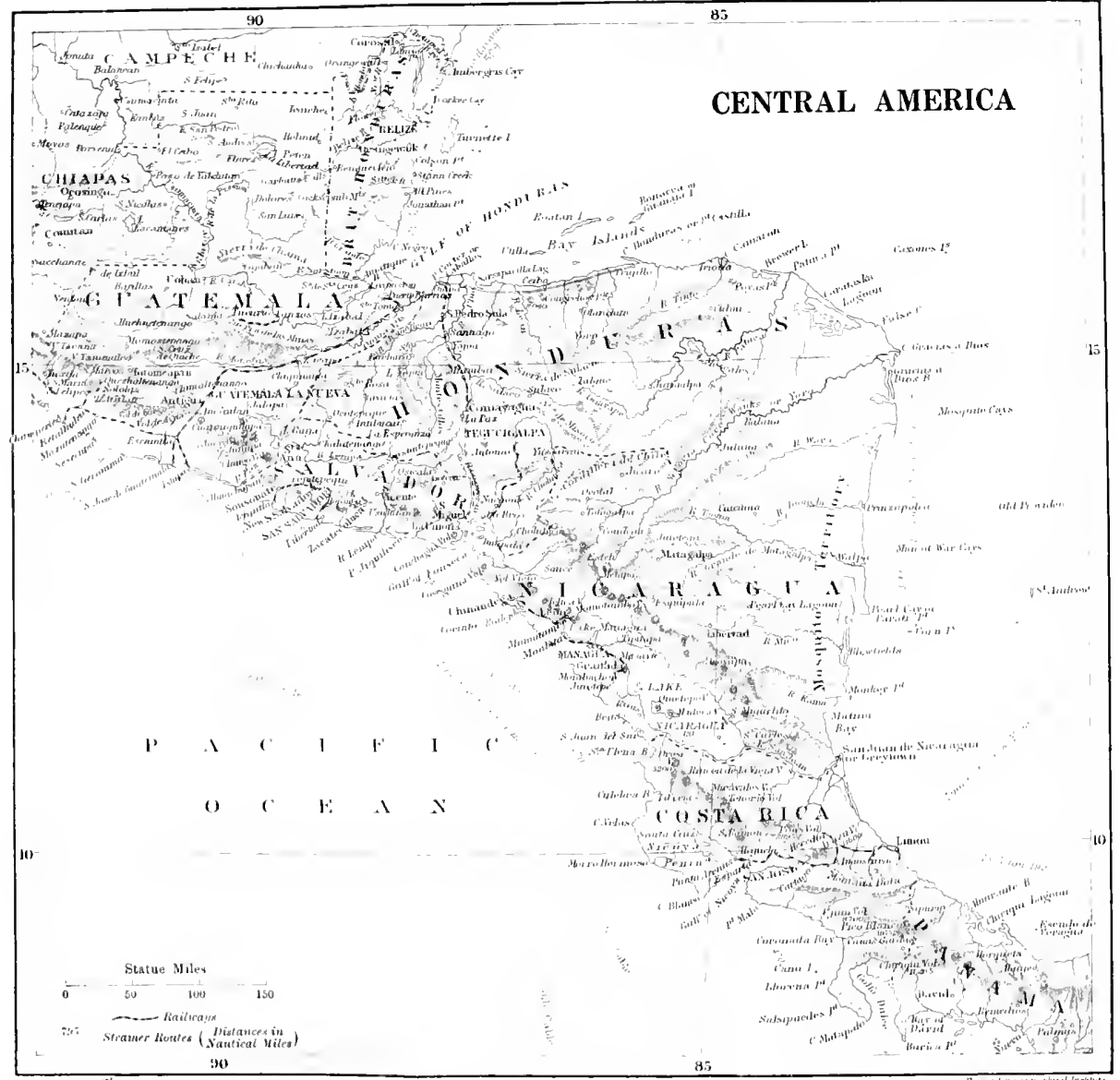


HSAm

DG7378

G U A T E M A L A

AND THE

\title{
STATES OF CENTRAL AMERICA
}

\author{
BY \\ CHARLES W. DOMVILLE-FIFE
}

AUTHOR OF

"The gReat states of South america," "SUbmakine engineERing of to.day" ETC. ETC.

ILLUSTRATED

LONDON :

FRANCIS GRIFFITHS
34 MAIDEN LANE, STRAND, W.C. $\frac{40905}{4.5 .43}$ 
"THE lands under the political dominion of the Latin American rations may be equalled in fertility, natural wealth and abundance of mineral deposits elsewhere on the surface of the globe; but they are nowhere surpassed. The coasts on the two oceans are generally provided with numerous safe and commodious ports; the mountains teem with all the mineral substances known to man ; gold, silver and platinum are found in the spurs of the Cordilleras and in the main ranges, and gold, especially, in the low valleys and in the beds of the rivers and streams."-_" Cambridge Modern History." 
1 


\title{
CONTENTS
}

PREFACE

FAGE

5

\author{
PART I \\ GUATEMALA
}

INTRODUCTION

CHAPTER

I. In the Beginning . . . . $\quad$ I 3

II. The Spanish Conquest . . . $2 \delta$

III. The Spanish Conquest $\quad$ • $\quad$ • 37

IV. Later History of Guatemala • • 45

V. The System of Government-Political

Division-The Army . . . $\quad 63$

VI. The Guatemala of To-day . 70

VII. The Atlantic Coast $\quad$ - $\quad$ • 77

Vili. From Atlantic to Pacific . $\quad 86$

IX. Guatemala City . $\quad$. $\quad$. 92

X. Guatemala City . . . . . 102

XI. The Fêtes of Minerva • • • + II5

XII. The Fanous Ruins of Antigua, Quirigua, AND UTATLAN . . . . I 20

XIII. The Pacific Coast . . . . I 30

XIV. COFFEE-GROWING . . . . . 136

XV. The North and West . . . I 40

XVI. Finance and Commerce • • • • 145

XVII. Minerals and Mining . • 152

XVIII. OfF the Beaten Track . . . 157

XIX. The Native Population . . . . $\quad$ i 169 


\section{PART II \\ NICARAGUA}

Chapter

I. "Nicaragua the Beautiful" . .

PAGE

II. Nichragua's Share in the History of Central America . • . . $\quad$ 185

III. The Country, the Cities, and the People 203

IV. Some Characteristic Features . , . 225

V. Railivays, Mining, and Agriculture • 239

VI. Finance and Conmerce. . . . . 247

\section{PART III}

\section{COSTA RICA}

I. The History and the Country . . 251

II. The People, the Cities, and Railways • 256

III. Agriculture, Mining, And Commerce 266

\section{PART IV}

SALVADOR AND HONDURAS

I. The Middle States in History . • 277

II. Salvador To-day . . . . 282

III. Through Salvador to Honduras. • 287

IV. HONdURAS . $\quad$. $\quad$. 293

Conclusion $\quad . \quad . \quad . \quad . \quad . \quad . \quad 308$ 


\section{LIST OF ILLUSTRATIONS}

\section{GUATEMALA}

\section{Map of Central America}

Frontispicce

FACING 1'AGE

In Fonseca Bay. The Traveller's first Glimpse of the Atlantic Coast of Guatemala $\quad$. $\quad$. $\quad$. $\quad$. $\quad$. $\quad$. 17

A Cloud Effect from the Crater of the Volcano "Agua," Guatemala $\quad 17$ Quezaltenango. Central America Square . . . . 32 Steamer on Lake Atitlan, Guatemala $\quad$ - . . $\quad$. 32

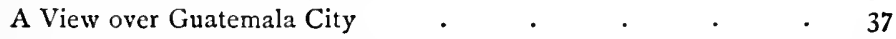

The Boulevard, Guatemala City . $\quad$ - $\quad$. $\quad$. 44

The Central Railway Station, Guatemala City . $\quad$. $\quad$. 49

The National Theatre, Guatemala City . . . . . $\quad 64$

The Market Place, Antigua, Guatemala . . . $\quad$. 69

The Plaza, Quezaltenango, Guatemala $\quad$ • $\quad$ • $\quad$ • 76

Ruins, Antigua, Guatemala . $\quad$ • $\quad$ • $\quad$. 76

Plaza de Centro-America, Quezaltenango, Guatemala . . $8 \mathbf{I}$

A Street Scene in Quezaltenango, Guatemala . . . $8 \mathbf{I}$

Helvetia, Guatemala $\quad$ • $\quad$ - . $\quad$. 96

A Coffee Estate, Helvetia, Guatemala . $\quad$ • $\quad$ - 96

A typical Plantation of Maize, Guatemalan Pacific Coast . . IOI

A typical Plantation Scene on the Guatemalan Pacific Coast - ror

The Slopes of "Santa Maria" from the "Valley of Fertility,"

Guatemala . . . . . . . 108

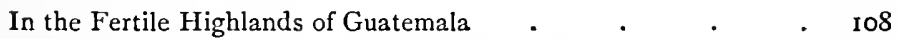

Cantel, from the surrounding Heights, Guatemala . $\quad$ - $\quad$ II3

A typical Roadside Scene in the Guatemalan Highlands . $\quad$ II3

Native Huts, Palmar, Guatemala . . . . . $\quad$ I28

A Domestic Scene (native) at Tzanhuji, Guatemala $\quad$ - $\quad$ I28

A Group of Distinguished Guatemalan Natives at Chichicastenango $\quad$ I 45

A Village Scene in the Interior of Guatemala . . $\quad$. 160

The old Spanish Church, Palmar, Guatemala . . . 160

\section{NICARAGUA}

The Central Park, Managua, Nicaragua . . . . 177

Entrance of the "Campo de Marte," Managua, Nicaragua I92

Cadets of the Military Academy, Managua, Nicaragua 197

Scene on Lake Nicaragua near Rivas, Republic of Nicaragua $\quad 204$

Washing and Drying Grounds on the "La Palmera" Coffee Estate,

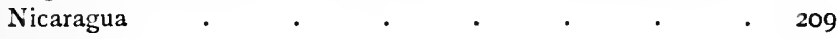




\section{COSTA RICA}

A Group of Indians, Central Costa Rica . . . . . 224

An Indian King and his Family, Costn Rica . • . 224

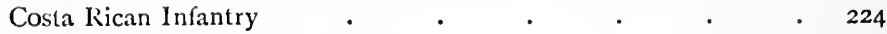

The Cathedral, San José, Costa Rica $\quad$. $\quad$. $\quad$. 229

The National Theatre, San Josć, Costa Rica . . . . $\quad 236$

A Public Cercmony in Costa Rica . . . . . $24 \mathrm{I}$

National Monument, San José, Costa Rica . . . . 24I

A Group of Costa Rican Pcasant Girls . . . . . . 24 I

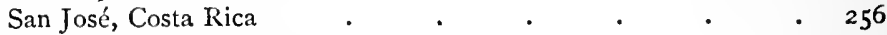

A Street in Port Limon, Costa Rica . . . . . 256

A Street in San José, Costa Rica . $\quad . \quad$. $\quad . \quad$. 256

Wharves, Port Limon, Costa Rica . . . . . 261

A typical Country Scene on the Costa Rican Railway . . 26r

Itotel Gardens, Port Limon, Costa Rica . . . . 26r

A typical Coast Scene on the Costa Rican Railway . . 268

Picking Coffee on a Costa Rican Estate . . . . 268

Reventazon River (showing Railway Embankment), Costa Rica . 268

Port Limon, Costa Rica . . . . . . $\quad . \quad 273$

The Turialba Volcano, Costa Rica . . . . . . 273

Park Scene, San José, Costa Rica . $\quad$ • $\quad$ • $\quad$ • 273

\section{SALVADOR}

The Theatre, San Miguel, Salvador . . . $\quad 288$

The Cathedral, San Salvador $\quad$. $\quad$. $\quad$. $\quad 288$

The Parish Church, Santa Ana, Salvador . . . . 293

A River Scene in "Sunny" Salvador . . . . 300

The Volcano of San Vicente y Pueblo de Guadalupe, Salvador . 300 


\section{PREFACE}

The kind reception by the Press and public, both in Europe and America, of my former works, "The Great States of South America," and "The United States of Brazil," is in part responsible for the production of the present volume, which continues the survey of Spanish America.

There was, however, one other factor which prompted the writing of this book-viz. the sincere admiration I have for the makers of these young nations and the many friends I have among them.

I wish specially to thank Señor Don D. Bowman, of the Guatemalan Legation in London; Señor Don Arturo R. Avila, Consul-General of Salvador; Señor Don Felipe E. Martinez, Consul-General of Nicaragua; Señor Don J. de Lacheur, Consul-General of Costa Rica, and Señor Don J. Kelly, Consul-General of Honduras, for the assistance they have so frequently rendered me.

I have also cordially to thank Dr Tempest Anderson for his kindness in permitting me to reproduce some of the photographs taken by himself; Mr Percy Allen, for his assistance with the early history of Guatemala ; Mr Davidson Boughey, Señor Don Carlos Morgan, and the many others, both at home and abroad, whose kindness will ever remain a pleasant memory. 
About the difficulties of the task of unravelling the tangled skein of Central American history, politics, finance and commerce, with but very complicated and contradictory data, I will say nothing, preferring to allow readers to judge for themselves from the events herein related.

Charles W. Domville-Fife.

Exeter, I9I3. 
PART I

GUATEMALA 


\section{GUATEMALA}

\section{INTRODUCTION}

THE Republic of Guatemala, following the same line of progress as the whole of Latin America, has, during the last ten years, greatly increased in prosperity, improved economically, and assumed a thoroughly settled political condition. The former statements are proved beyond question by the steady rise in home and foreign trade, and the ever-increasing interest evinced by European and American financiers and merchants in the exploitation of this undoubtedly rich country.

Many otherwise well-informed people know but little concerning Guatemala. They have a vague idea that it is situated somewhere in South or Central America, and is subject, consequently, to unbearable tropical heat, accompanied by epidemic diseases, that it is also constantly in a state of excitement and political unrest.

To these, the following pages, supported by that strongest of arguments-fact-will come as a revelation.

It may be said at once that, owing to the elevated position of the capital and the whole centre of the country, the climate in this, the most important zone of the state, is that of a perpetual European summer; only the coast lands being considered tropical.

The settled state of the country and the peaceful disposition of the inhabitants is proved conclusively by the many years of tranquillity which Guatemala has now enjoyed, notwithstanding the wars and revolutions which have frequently raged around its frontiers. 
The present "Helmsman-of-the-Ship-of-State "Don Manuel Estrada Cabrera-by whose untiring efforts Guatemala has attained her present position of importance, is a patriot in the truest and best sense of the word. He lives for his country, and works day and night for its welfare. It is no idle compliment to say that no president in Central America has ever yet exhibited such wonderful powers of statesmanship, nor an equal faculty for readily knowing what is good and what is bad for the country which he is called to govern.

Some people, no doubt, will be a trifle sceptical upon this point; but, before passing judgment, let them realise what Guatemala was, only a few years ago, as compared with what it is to-day; let them know the man, and then, doubtless, they will share the author's feelings of admiration and respect for the greatest and most powerful statesman in Central America, engaged in the stupendous task of building up a first-class nation in the New World.

When President Cabrera was first elected, the country was in a terribly disorganised condition; and education among the poorer classes was much neglected. Now there are I80o elementary schools scattered all over the republic, and secondary education is compulsory. The two oceans have been connected by a railway system; the telephonic and telegraphic nets have been extended; the postal service is regular; the whole country is settled in its administration, and the establishment of the Bureau of Central American Republics in Guatemala City has united the four states of this portion of the continent by a tie that, year by year, should grow stronger. That which, perhaps, has been the greatest cause of misunderstanding is the difference existing between some of the disturbed surrounding republics and Guatemala. Political unrest, in any of these countries, has been held up as an example 
of the unsettled state of the whole of Central America -an assumption as unfair as it is false.

One of the departments of public interest that has most occupied the attention of the present ruler is education ; and it may safely be said that Guatemala, in this respect, is now among the most advanced countries of Latin America. The medical and sanitary services also have been completely reorganised upon the most up-to-date European methods.

Regarding the foreign trade of the republic, from I865 to I904, Great Britain was the chief exporter to, and importer from, Guatemala; but, from that time, the first place has been held by the United States, the second by Germany, followed by England, France, Mexico, Italy, and Spain.

The government is republican and representative, being composed of the executive, legislative, and judicial bodies. The first is controlled by the President, who remains in office for a period of six years, being responsible for his actions to Congress. He is assisted by six ministers, or secretaries of State. The legislative power is vested in the Assembly, composed of one member for every 20,000 inhabitants. Foreigners are entitled to the franchise.

Although the standard of currency is the silver peso, or dollar, much paper money and fractional nickel coin is in circulation, owing to political circumstances, which rendered such an issue necessary during the presidency of General Rufino Barrios. This, however, is to be called in, as the Government is adopting the silver standard, which is to be followed by the gold standard. The paper peso, or dollar, is worth, approximately (subject to fluctuations), about three English pence.

These financial changes should do much to facilitate commerce, by encouraging European traders to take more advantage of the miscellaneous openings for 
substantial business. A better standard currency is of the greatest value, not only for internal trade, but also in helping to allay, for merchants from without, the terrors of the unknown.

With these brief introductory remarks concerning a country that, before being worthily exploited, needs only to be understood, let us ring up the curtain, and endeavour to show to our readers Guatemala as it is. 


\section{CHAPTER I}

\section{IN THE BEGINNING}

Guatemala has often been described, as in Mr Pepper's book, ${ }^{1}$ for example, as the Land of the Future; and certainly its prospects are as rosy as those of any country in Latin America. But such sounding phrases should not lead any reader to suppose that the country's past is unworthy of attention. On the contrary, it may safely be asserted that the early history of Guatemala is as stirring and interesting as that of any Spanish-American country, with the possible exception of Peru. I propose, therefore, to devote the first chapters of this book to a short account of the events that have raised the republic to its present prosperous condition.

Long before the dawn of written history this portion of Central America was inhabited by a nation skilled in the arts of weaving by hand, carving, and metal-work. When, in the sixteenth century, the Spanish adventurers came from over the sea, they discovered, in ruined temple and beside stately monolith, priceless treasures of antiquity. Exquisitely carved vases, copper ornaments covered with hieroglyphics, curious images and strange gods of gold and silver, all told them tales of an early civilisation which historians and antiquarians believe to have resembled that which flourished under the famous Incas of the Bolivian tableland.

1 "Guatemala-the Country of the Future," by Charles M. Pepper. 
These interesting, yet barbarous, people worshipped their graven images with the intense devotion of the heathen, and offered human sacrifices to appease the wrath of their deities, who, to the superstitious native minds, exhibited their anger by the lightning flash from heaven, or by bidding the mountains spit forth flame. Their temples were magnificently decorated with pictures and altars of carved stone, adorned with finely worked ornaments. The tiled floors were covered with rich carpets, and the masonry of these holy edifices must have called for the united labour of many hundreds, so splendidly was it fashioned.

The true origin of this strange race of Guatemalan Indians is a mystery the solution of which lies hidden deep in the realms of myth and fable. Some believe that they are the descendants of the yellow men, whom ancient tradition asserts to be the first settlers in the land. Certain it is that the Indians can understand and be understood by the Chinese with more facility than is the case with any other stranger race. We must remember, too, that the sacred book, "Popol Vuh," with which we shall deal later, states that primitive man was made of clay; thus confirming the universal tradition that the primitive American was formed of red or yellow earth. With these myths and legends we must be content, until the patient researches of antiquarians shall have given us the key to the hieroglyphics that, upon the stones of Central America, at Palenque, at Copan, at Quirigua, and elsewhere, tell us their tale of the past.

In times very remote there came down from the north a people called the Nahoas, whose great chief was Quetzalcoatl-that is, " the serpent with the plumes of the Quetzal "-or Gucumatz, as he is called in "Popol Vuh," " the serpent with the skin of green and azure." This Gucumatz succeeded in overthrowing Xibalbag; another great chief then ruling in the land, whose sub- 
jects were scattered broadcast. Some went northward to Mexico, and, when famine drove them thence, returned, after some four hundred years, and founded, in the seventh century, the kingdom of Hucytlat, in Honduras, whose principal city, Copantl, is now represented by the strange ruins of Copan.

Another inroad from the north appears to have resulted in the foundation of the tribe known as the Quichés, a powerful race, to whom the other neighbouring tribes in turn submitted. The Quiché dominions gradually grew in extent, until they stretched from Mexico to the Pacific Ocean, and eastward as far as Lake Izabal. We do not know very much about the history of these people, but from the chief source of our information, their most interesting sacred book, " Popol Vuh," they appear to have had a certain civilisation and an established feudal system comparable only with that of mediæval Europe. The Spanish writers credited these ancient kings with magic powers. They tell how Gucumatz transformed himself into a serpent, a jaguar, an eagle ; how he dwelt seven days in heaven, and abode seven days in hell. "Surely great was the respect he gained by these miracles before all the lords and all those of his kingdom." 1

The reader will wish to learn something of this fascinating book, "Popol Vuh." Two translations exist-one in Spanish, by Zimenes, and the other in French, by the Abbe Brasseur de Bourbourg, of part of whose version I give an English rendering. I wish that space permitted me to go into the story at greater length, but what I quote will be enough to afford the reader some idea of the Quichés outlook upon life, and his mode of thought. The opening passages give, in the poetical diction natural to aboriginal races; a vivid account of the creation of the world, and the beginnings of Man. 
"This is the story of the time when all was in suspense, when all was calm and silent ; all was motionless, all was peaceful, and void was the immensity of the heavens.

"This then is the first word and the first of specches. There was not yet one single man, not an animal; no birds, no fishes, no crayfish, no wood, no stone; no bogs, no deep gulfs, no grass nor forests; only the sky existed.

"The face of the earth was not yet seen; naught was there save the peaceful sea and all the expanse of heaven.

"There was nothing of which a body might be shaped, nothing that clung to any other thing; nothing that swayed, nothing that caused the slightest rustle, nothing that would make a sound in the sky.

"There was nothing that stood upright, only the tranquil water, only the sea calm and alone within its bounds ; for nothing existed.

"There dwelt but immobility and silence in the darkness, in the night. Alone, too, the Creator, the Fashioner, the Ruler, the feathered serpent. Those that beget, those that give being, brood over the water like a kindling light.

"They are clothed in green and azure, therefore are they named Gucumatz ${ }^{1}$; they take their being from the greatest sages, even thus the heavens exist, thus, too, the Heart of heaven; such is God's name ; by that name is he known. 'Twas then that his word came hither with the Ruler and Gucumatz, in the darkness and in the night, ${ }^{2}$ and that it spoke with the Ruler, the Gucumatz.

${ }^{1}$ A serpent whose skin is green and blue. The green and blue symbolise strange and mysterious clothing originating perhaps in the colour of trees and sky.

${ }^{2}$ The phrase "darkness and night" refers in this book, as in all others of the same origin, to an epoch previous to the Nahuatl civilisation. 



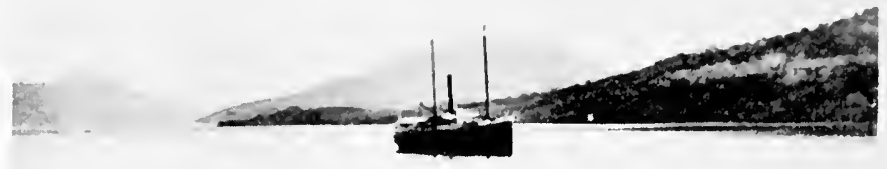

In Fonseca Bay. The Traveller's first Glimpse of the Atlantic Coast of Guatemala

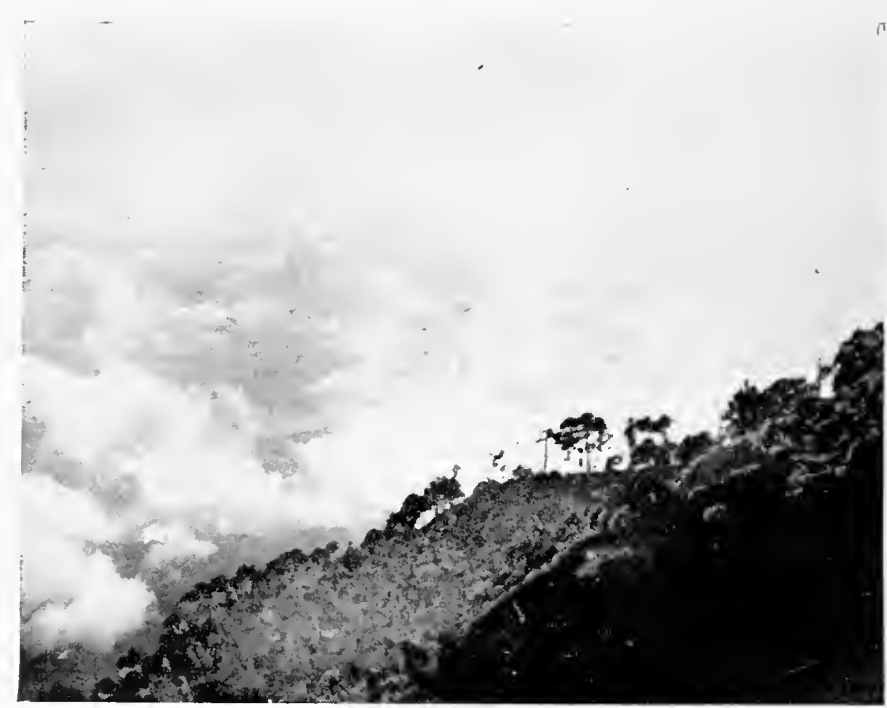

A Cloua Effect from the Crater of the Volcano "Agua," Guatemala Facing fage' 17 
" Then they spoke; then they took counsel together and meditated; they understood one another; they joined words and opinions.

"Then while they took counsel together the day broke, and at the moment of dawn man was manifested; while they held counsel upon the production and the growth of the woods and the creeping plants, on the nature of life and humanity (fashioned), in the darkness and in the night, by him who is the Heart of heaven, whose name is Hurakan. ${ }^{1}$

"The Lightning is the first (sign) of Hurakan; the second is the track of the Lightning; the third is the Thunderbolt that strikes; and these three are of the Heart of heaven. Then they came with the Ruler; the Gucumatz; then they held counsel upon civilised life how the sowings should be done; how there should be light ${ }^{2}$; that should be the support and the nourisher (of the gods). ${ }^{3}$

" 'So be it done. Be ye filled,' it was said. 'Let this water be withdrawn and cease to hinder us, so that the land may exist here, that it may be brought together and show its surface, so that it may be sown and that the day may shine in heaven and upon earth; for (we receive) neither glory nor honour for all that we have created and formed; until the human creature exist; the creature gifted with reason.'

" Thus they spoke, while through them the earth was forming. Then truly did creation take place, thus the earth came to be: 'Earth,' said they; and at that moment it was formed.

1 This word, not found in the native dictionaries, appears to have originated in the Antilles, where it signified tempest and the growing of the storm: Hence our word hurricane.

${ }^{2}$ This word is almost always used in a metaphorical sensethe light of civilisation to shine on a people still in darkness.

${ }^{8}$ The reference is to the nobles and priests who by establishing and retaining religion would support the gods. 
" Like a fog or a cloud it was formed in its material state, when like lobsters the mountains appeared above the water ; and in an instant the great mountains were.

" Only by might and by a marvellous power ${ }^{1}$ could be done that which was resolved upon concerning the hills and the valleys, instantaneously with the creation of the woods of cypress and of pine (which appeared) upon their surface.

"And thus was Gucumatz filled with light-heartedness: 'Be thou welcome,' cried he, 'O Heart of heaven, O Hurakan, O Track of the Lightning, O Thunderbolt that strikes!'

" "That which we have created and found, shall be perfected,' replied they. And first were formed the earth, the mountains and the plains ; the watercourses were separated; the streams flowed winding between all the mountains; in this order the waters came into being, when the great mountains had been unveiled.

"After such fashion was the creation of the earth; when it was formed by those who are the Heart of heaven and the Heart of the earth; for thus are named those who first made it fruitful, heaven and earth, still inert, being suspended in the midst of the waters.

"Then ${ }^{2}$ they gave fruitfulness to the animals of the mountain, who are the guardians of all the forests; of the beings who people the hills, of the stags, of the birds, of the lions, of the tigers, of the serpents, of the viper and of the Qunti ${ }^{3}$ guardians of the climbing plants.

"Then spoke he who engenders, he who gives being: 'Is it then only for silence ; is it then only for life without motion that the shadows of the woods and of the climbing plants exist? Henceforth it is well that there be beings to watch over them.'

1 Naual, generally used in a supernatural or supernormal sense:

2 Here begins the second chapter of "Popol Vuh."

${ }^{3}$ Qanti, a very dangerous serpent, beautifully coloured: 
" Thus they spoke, while they were bringing about fruitfulness; while they were taking counsel together ; and immediately the stags and the birds existed. Then they appointed to the stags and the birds their abodes :

" "Thou, stag, beside the streams, in the ravines, thou shalt sleep; here shalt thou rest between the undergrowth and the grasses ; in the woods you shall multiply yourselves, upon four feet you shall go, upon four feet you shall live.' So it was done as it was spoken unto them.

"Then all the birds and beasts were created; and their abodes given unto them, and he who is the Creator; the Fashioner, he who engenders, he who gives being, spoke again :

Roar, warble now, since the power of roaring and warbling (is given to you) ; let your language be heard, each according to his kind, each according to his race.' Thus was it spoken to the stags, to the birds, to the lions, to the tigers and the serpents. : Repeat your name, honour us, us who are your mother, who are your father ; invoke, then, Hurakan, the track of the Lightning, the Thunderbolt that strikes, the Heart of heaven, the Heart of the earth, the Creator and the Fashioner, he who engenders, and he who gives being, speak, call us, and salute us '; thus was it spoken unto them. But it was impossible for them to speak like a man; they did naught but cackle, cluck, and croak; without any form of language appearing, each after his kind murmuring in a different manner.

"When the Creator and Fashioner heard that they could not speak, they said again one to another: 'They have not been able to name our name, though (we are) their creators and their fashioners.' ' That is not good,' repeated one to the other, he who engenders, and he who gives being.

" And it was said unto them (the animals): 'Behold you shall be changed, because you have been unable to 
speak. Therefore we have changed our word; your nourishment and your food, your dens and your habitations shall you still have; (but) they shall be the ravines and the woods, for our glory is not perfect, and you invoke (us) not.

" There are such (beings), there are yet doubtless such beings, as shall be able to salute us; them shall we make capable of obedience. Now do your duty; as for your flesh, it shall be broken between the teeth; so be it.'

"So all the animals, great and small, were warned of their changed destiny, and in order to avert it they made a great effort to agree together upon a new mode of adoration; but all in vain, for they could not understand one another's language. Then he who engenders and he who gives being set about the creation of a new race that should honour and salute and at the same time support and assist the gods.

"Thus spake they. Then the creation and formation (of man took place); of clay they made his flesh. ${ }^{1}$

" They beheld that he was not well (fashioned); for he was without cohesion, without consistency, without movements, without strength ; inept and watery; he could not move his head, his face turning but one way ; his sight was veiled and he could not see behind him; he had been gifted with language, but he had no intelligence, and; moreover, he wasted away in the water without (being able) to stand upright.

"Now the Creator and the Fashioner were still thoroughly dissatisfied with their work, so they destroyed their own creatures and again counselled together how they might bring forth beings who should adore and invoke their makers. For that purpose they asked the advice of Xpiyacoe and Xmucané, the grandsire of the

${ }^{1}$ Very curious to note that, according to all tradition, the primitive American was formed of red or yellow earth: 


\section{IN THE BEGINNING}

sun, and the grandsire of the light ${ }^{1}$; and they took to their counsels the heavenly astrologers and astronomers, and the begetters of the jewellers, and the architects that they might discover, by divination, whether or no the mouth and face of the new men should be sculptured in wood. And at last it was agreed that they should be so fashioned.

"At that very instant was made the mannikin in wood, men produced themselves, men reasoned and these are they that (dwell) on the face of the earth.

"They existed and they multiplied ; they engendered daughters and sons, mannikins fashioned in wood; but they had neither heart not intelligence, nor remembrance of their Fashioner or Creator ; they led a useless existence and lived like the animals.

"They remembered no more the Heart of heaven, and that is how there they fall away; it was no more therefore than a trial and an attempt at men, who spoke at first, whose faces withered; without consistency (were) their feet and hands; they had neither blood nor subsistency, nor moisture, nor fat, their faces were but withered cheeks, dried up were their feet and hands, emaciated their flesh 1

"That is why they thought not (to lift) their heads to the Fashioner and Creator, their father and the provider. Now these were the first men who existed in great number on the face of the earth.

"Then ${ }^{2}$ (came) the end (of these men) their ruin and their destruction, of those mannikins, wrought of wood, who also were put to death.

"Then the waters were swollen by the will of the Heart of heaven; and there came a great flood that passed over the heads of these mannikins and of these beings worked in wood.

${ }^{1}$ These names mean here the authors of the calendar:

${ }^{2}$ Here begins Chapter III. of " Popul Vuh.". 
Taite ${ }^{1}$ formed the flesh of the men; but when the woman was made by the Fashioner and the Creator, Zibak ${ }^{2}$ was the woman's flesh.

"But they neither thought nor spoke of their Fashioner, their Creator, he who had made them, who had caused them to be born. And their destruction was in this wise, they were swept away by a flood, and thick pitch fell from the sky. (The bird) named Xecotcovach came and tore their cyes from the sockets, the Cotzbalam devoured their flesh, the Tecumbalan ${ }^{3}$ broke and smashed their bones and their cartilages; and for the chastisement of their persons, their bodies were reduced to powder and scattered.

"Because they had given no thought to their mother and their father, to him who is the Heart of heaven, whose name is Hurakan, because of them the face of the earth was darkened, and a shadowy rain began to fall, rain by day and rain by night.

"And so all these animals; great and small, their dishes and their pots, the very stones on which the women ground the maize, rose up in rebellion against man doomed of the gods. And mankind began to run hither and thither, filled with despair; they sought to climb upon the roofs of the houses, and the houses, collapsing, let them fall to the ground; they sought to climb the trees, and the trees shook them far away; they sought to enter the caverns, and the caverns closed before them.

" Thus was accomplished the ruin of these human creatures, people destined to be destroyed and over-

"A tree on which grow red beans called by the French "graines d'Amérique." The sorcerers or diviners of the country used them for telling fortunes.

${ }^{2} \mathrm{Zibak}$ - the pith of a small reed, of which the natives make their mats.

2 These names are those of various birds of prey, to-day unknown. 
thrown, thus were their persons all delivered to destruction and shame. Moreover it is said that their posterity (is still seen) in those little monkeys that live in the woods to-day; that is the sign that remained of them, because of wood only was their flesh made by the care of the Fashioner and the Creator.

That is why the little monkey resembles man, sign that he is of another generation of human beings (who were) but mannikins, but men wrought in wood."

The gods were already considering the creation of a really superior class of man, when further trouble arose through the overwhelming pride of one VukubCakix, who imagined himself to be a kind of Lucifer, a god among men.

" " I am their sun; I am their dawn and I am their moon; so be it. Great is my splendour ; I am he by whom men move and walk. For of silver are the balls of my eyes that glitter like precious stones, and the enamel of my teeth shines like the face of heaven. . . .'

"Thus spoke Vukub-Cakix. But in sooth he; Vukub-Cakix, was not the sun; only he was puffed up by his jewels and his riches. But in reality his sight ended where it fell, nor did his eyes range over the whole world. For the face of the sun was not yet seen, nor of the moon, nor of the stars; it was not yet day."

Then comes the story of how the pride of VukubCakix was broken by two young people named Hunahpu and Xbalanque.

"This is now the story of the blowpipe shot fired upon Vukub-Cakix by the two young people. . . . This same Vukub-Cakix had a great tree of the kind 
called Nanze, and that was the food of Vukub-Cakix, who was wont to come to the Nanze-tree and could climb every day to the top of the tree, to see the husks of the fruit that had been caten by HunhunAlıpu and Xbalanqué.

"For their part, then, spying Vukub-Cakix at the foot of the tree, the two young men hid themselves in the foliage, awaiting Vukub-Cakix; who was coming to devour the nanzes which were his food.

"Then he was struck by a shot from the blowpipe of Hunhun-Ahpu, who with a ball from his blowpipe shot him in the mouth; he uttered cries as he fell from the top of the tree to the ground.

"Hunhun-Ahpu hastened after him and ran upon him at once to take him; but Hunhun-Ahpu let himself be seized by an arm by Vukub-Cakix, who instantly wrenched it and tore it violently from the end of his shoulder. . . .

"Carrying thus Hunhun-Ahpu's arm, Vukub-Cakix reached his house holding his jaw.

"'What has happened to your lordship?' asked Chimalmat, Vukub-Cakix's wife.

" What should it be but that these two rascals have shot me with their blowpipe and broken my jaw; so that they have shaken my jaw-bone and my teeth, which are hurting me very much; (as for his arm that I have torn out) I am bringing it to the fire to hang it over the brazier till these demons come to take it back,' said Vukub-Cakix, while he was hanging up Hunhun-Ahpu's arm.

"Hunhun-Ahpu and Xbalanqué; having held counsel together, spoke of the matter to an old man, also to an old woman, and in sooth the head of this old man was quite white, and truly this old woman was bowed and bent in two with old age.

" The old man's name was the Great White Boar and the Great White Thorn Pricker was the name of 
the old woman. Then the young man said to the old woman and to the old man: "Will you accompany us to go and take our arm from the house of VukubCakix? We will go behind you (and you shall say); "These are our grandchildren we bring with us, their father and their mother are dead. So they follow us everywhere where it suits us to let them come; for our trade is to draw the worms from people's teeth," you will say.

" "So Vukub-Cakix will think we are children and we shall be there to give you our counsel, 'said the two young men. 'Very well,' replied (the two old people).

"Then they set out towards the place where VukubCakix was lying at the foot of his throne; then the old man and the old woman passed by, the two young men playing behind them, and as they passed before the king's house (they heard) the cries that VukubCakix was uttering because of his teeth.

"Now as soon as Vukub-Cakix perceived the old man and the old woman and those who were with them, 'Whence come you, my aged ones?' said the king to them immediately. "We are going in quest of our livelihood, O my lord,' they replied.

" By what means do you live? Are these your children that accompany you?' 'Not at all, my lord; these are our grandchildren; but you see we have pity upon them, we share with them and give them half our food,' replied the old man and the old woman.

"Now the king was at the end of his strength by reason of the suffering his teeth caused him, and he spoke with effort. 'I conjure you, now have pity on me,' said he. 'What do you, what manner of things can you heal ?' added the king.

" "We just draw worms from the jaw; we cure (ills) of the eyeballs, and we replace bones, $\mathrm{O}$ my lord,' replied they. 
" "Very well. Heal at once, I beg of you, my tecth which in sooth cause me to suffer every day; for I have neither rest nor slcep because of them and for pain in my cyes.'

" "Two demons shot me with their blowpipe to begin with, for which cause I can no longer eat : have pity on me then: for everything rattles (in my mouth), my teeth and my jaw.'

" "Very well, my lord. 'Tis a worm that is hurting you; we have only to change (your jaw) by removing your Highness' bad teeth.' 'Will it be well to take out my teeth? for by these alone am I king ; and all my beauty comes from my teeth and the balls of my cyes.' 'We will at once put in others in exchange, pure and clean bones shall be put in their place '; but these pure and clean bones were nothing else than grains of white maize.

" 'Very well; draw them then and come to my aid,' replied he. Then they took out the teeth of VukubCakix; but they put back only grains of white maize in exchange, and at once you could see those grains of maize shining in his mouth.

"Immediately his splendour fell, and he ceased to appear kingly. They succeeded in taking from him his teeth of precious stones that sparkled in his mouth. While they were at work on the eyes of Vukub-Cakix, they skinned his eyeballs, at the same time completely despoiling him.

"But he was no longer in a condition to feel it; he could still see well, but the cause of his pride had in the end been taken from him utterly, by the counsel of Hunhun-Ahpu and Xbalanqué.

"So died Vukub-Cakix, whilst Hunhun-Ahpu took his arm again, and then died also Chimalmat, the wife of Vukub-Cakix.

"Such was the destruction of the riches of VukubCakix. The old woman and the old man who did these 


\section{IN THE BEGINNING}

things were marvellous beings. For, having taken the arms (of the two young men) they replaced them, and having fastened them on again, the whole held firmly.

"Solely to bring about the death of Vukub-Cakix, they chose to act thus, for it seemed to them an ill thing that he should be so puffed up. After that the two people went their way, having carried out (in this manner) the will of the Heart of the heaven."

Space does not allow us to carry further the adventures of these and many other equally mysterious beings, but we have told enough to give the reader some idea of the charm and interest attaching to this naïve and confused, yet quite human and natural, attempt of primitive intelligences to account for their own existences, and to solve problems by which scientific discovery, even, must, for ages yet to come, consent to be baffled. 


\section{CHAPTER II}

\section{THE SPANISH CONQUEST}

YEARS rolled by, and gradually the Quichés lost the power they had formerly held. In the beginning of the fifteenth century they had, for many years, been amalgamated with the Toltecs of the northern portion of the isthmus. This union formed a powerful race, which had reached the high state of primitive civilisation at which we have already hinted, when Don Pedro de Alvarado marched forth from Mexico, bent on the conquest of Guatemala.

The story of this early empire and the autocratic government of the Toltecs, as the Quiché nation may now be called, was discovered, written in hieroglyphics, on paper made from the bark of trees. These very ancient and valuable records, according to Spanish and American writers, tell us, as the reader will remember, that the Chinese were the first foreign people to land upon the shores of Guatemala. Then came the Portuguese ; other documents state that Columbus also landed during one of his famous voyages of discovery.

The story of the conquest of Guatemala by Alvarado is best found, from the Spanish point of view, in the memoirs of Castillo and the letters of Alvarado himself. Cortes, who, according to Castillo, was always striving "to emulate Alexander of Macedon," and must therefore necessarily dream often of conquest and dominion, hearing that there was gold in Guatemala, determined to add that country to his fast-expanding 


\section{THE SPANISH CONQUES'T}

possessions. Having several times unsuccessfully invited the inhabitants to submit, he sent Pedro de Alvarado, with 300 foot, I53 horse, with four field pieces and an abundant supply of powder, to accomplish by force of arms the task of subduing these warlike natives. Alvarado was accompanied also by Father Olmedo; whose ardent attachment to the Catholic faith had led him to hope that, with the help of his interpreters, he would be able to induce the inhabitants to abandon their human sacrifices and other abominations, in favour of the rites of the Christian Church.

Alvarado took leave of Cortes, and left Mexico, on the I5th of December I523, for the then thickly populated land of Guatemala. $\mathrm{He}$ was well and peaceably received at first; and was offered presents of gold, but later, as he passed on, the natives began to assume a warlike appearance, and, in the neighbourhood of Zapotitlan, he came to a bridge over a river in a dangerous pass which was defended by large bodies of the enemy drawn up in battle array. A desperate battle ensued, and though the Spaniards wrought havoc in the enemy's ranks they were obliged to renew the attack three times before their valiant foes gave up the fight, and submitted, as vassals of the Empcror of Spain. Another fierce battle at Quetzaltenango followed, when Alvarado's men again put the native army to flight, and strewed the battlefield with dead and dying. The Spanish losses in these fights seem to have been comparatively insignificant.

"From this place his route lay through a dangerous and very narrow mountain defile, about six miles in length. The troop; therefore marched forward with every military precaution, and began to ascend the acclivity. When they arrived at the most elevated point of the pass, they found a fat old Indian female 
and a dog, which had been sacrificed to their gods; a certain sign of war. This indeed was soon verified; for they had not marched far before they came up with immense bodies of the enemy, who were lying in wait for them, so that Alvarado stood in great danger of being hemmed in on all sides. At this spot the pass was so narrow, and the ground so thickly strewed with stones, that the horses were scarcely able to render any assistance; but the crossbow-men, musketeers, and the rest of the foot, armed with bucklers and swords, closed the more bravely with the enemy, who retreated; fighting, down the pass to some deep hollows, where other bodies stood drawn up in order of battle. From this place the enemy, by a preconcerted plan, fell back as Alvarado advanced, to another position, where they had posted 6000 of their men. These were the warriors and subjects of Utatlan, who had made sure they would be easily able to cut off Alvarado, with the whole of his men; but our troops fought with such determination and courage that they put the enemy to flight, having only three of their men and two horses wounded. The enemy, however, rallied again, were joined by other large bodies, and renewed the attack with great intrepidity. The most desperate part of the action took place near a fountain, where a strong body of the encmy rushed forth from an ambush; so that the Spaniards were compelled to fight foot to foot with the Indians, who had in particular singled out the cavalry, and each horse was attacked by three of the enemy, while several others at the same time strove to pull them to the ground by hanging to their tails. Here the Spaniards were placed in the utmost danger, for the enemy's numbers were overwhelming; but Father Olmedo encouraged the men, reminding them that they were fighting with the intention of serving the Almighty, and to promote His Holy religion; that the Lord would assist them; 
and that they must either conquer or dic in this battle." 1

Ultimately, the Spaniards gained a complete victory, and Alvarado took the opportunity to rest his wearied troops, many of whom were wounded, at the town of Quezaltenango. Shortly afterwards, however, he was again attacked by an army of 16,000 men, determined, this time, to conquer the invaders or die. But Alvarado was wary enough to await the enemy's onset upon an open plain, where his cavalry had space in which to manœuvre. The horsemen promptly put the enemy to flight, and at last really succeeded in impressing upon the Indians the fact that they were no match for the invaders, however greatly the latter might be outnumbered. In these circumstances, the Indians resorted to trickery. They sent peace envoys to Alvarado, with a small present of gold, hoping thereby to induce the Spaniards to retire to Utatlan, a town surrounded by deep hollows. Once immured within these, treachery might succeed, though battle had failed. The envoys duly handed to Alvarado their " miserable present," as Castillo terms it, and with courtesy and humility begged him to pardon their late hostilities, to acknowledge them as vassals of the great emperor, and to accompany them to the excellent quarters provided for their reception at Utatlan. Alvarado, suspecting nothing, acceded to all their requests, and marched with his troops to Utatlan. But the Spaniards, on arriving in the town, were struck by the warlike aspect of the place. There were only two gates by which the town could be entered, one of which was approached by a flight of twenty-

${ }^{1}$ Alvarado in his first letter to Fernando Cortes (I Ith April 1523) intimates that part of the Indians' discomfiture was due to their fear of the horses: "I They had never seen horses; they were terrified of them, and fled on all sides"? "Castillo's Memoirs," Chap. CLNIV.). 
four steps, and the other by a causeway which was intersected in several places. But here let Alvarado speak for himself. ${ }^{1}$

"As the houses of this town are very close together and the streets very narrow, we should all indubitably have been burned, or forced to throw ourselves down from the rocks. Immediately on entering the town, having noticed that it was very strong, and the streets too narrow and too angular for horses to be of much use to us, I decided to return to the country. The chiefs nevertheless tried to dissuade me from it, telling me to wait until they had supplied me with provisions, when I could depart. Seeing what danger we were in, I instantly ordered my troops to descend into the plains by the causeway and the bridge. One could scarcely ride a horse down this street; and all the outskirts of the town were full of soldiers. As soon as they saw me in the open country, they withdrew, but not without inflicting some loss; nevertheless I pretended not to noticc it. Wishing to capture the missing chiefs, I employed craft, and distributed presents to keep them quiet. I captured them, kept them prisoners in my camp. Their subjects, however, never ceased from fighting; they killed and wounded a large number of my Indians who had gone to get forage for our horses. They killed with an arrow a Spaniard who was foraging a cross-bow shot from the camp. Persuaded that by ravaging and burning the country, I could bring it to submission to his Majesty's power, I resolved to have the chiefs burned. At the moment of being burned, they avowed, as may be seen moreover from their confessions, their plan to burn us in the town, and the measures they had taken

1 These letters of Pedro de Alvarado to Cortes are given in !s Voyages, Relations, et Memoirs originaux pour servir à l'histoire de la découverte de $1^{2} \mathrm{Amé} r i q u e, "$ by $\mathrm{H}$ : Ternaux Compans. 


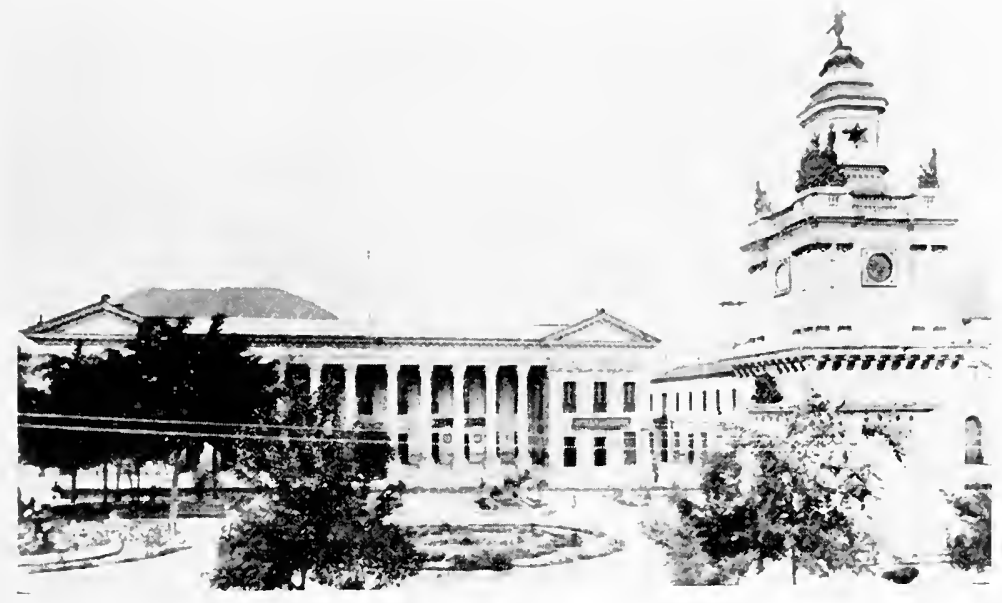

()uezaltenango. Central America Syuare

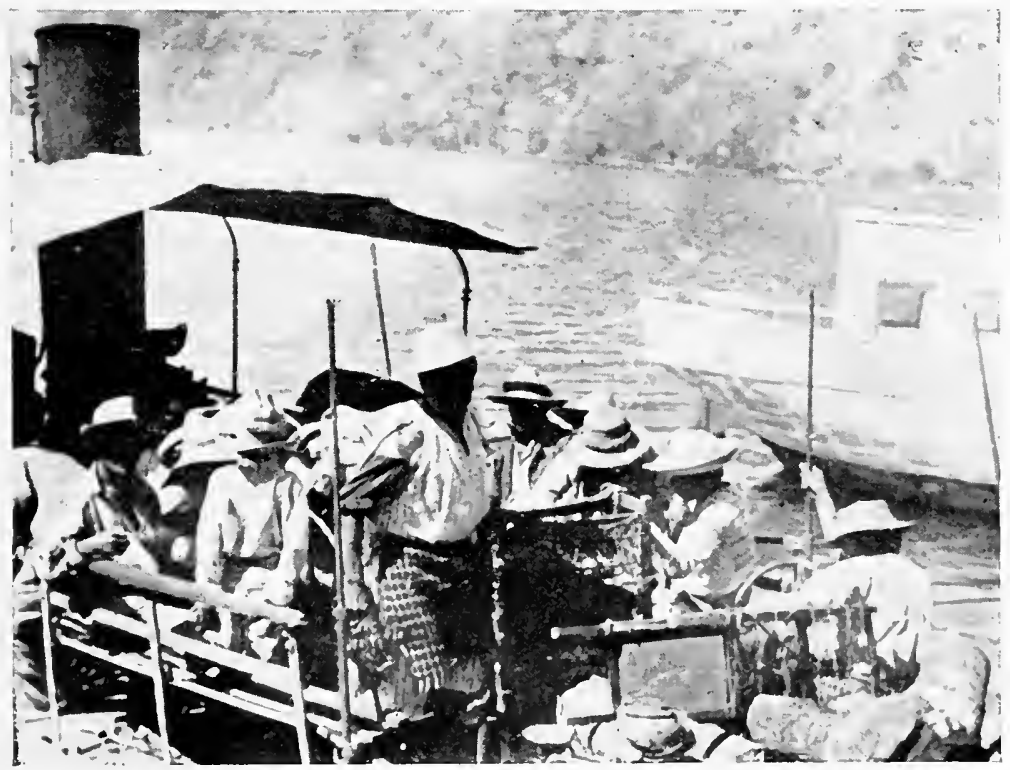

Steamer on Lake Ititlan, Guatemala 



\section{THE SPANISH CONQUES'T}

to that end ; they said that they had brought us there for that purpose, that they had forbidden their subjects to recognise the power of the emperor, our master, and to do anything to help us. Having learned their ill-will relatively to his Majesty's service, and believing that it would tend to the peace of the country, I ordered them to be burned, the town to be fired and ruined from top to bottom. It was so strong and dangerous that it was more like a bandit's haunt than a habitation of citizens."

It appears from Castillo's diary, that before Alvarado had carried out his amiable intention of burning the chiefs at the stake, Father Olmedo begged permission to be allowed to convert the chief Cacique to Christianity. He obtained for the wretched man one day's respite, then a second day, " at the end of which it pleased the Lord Jesus to incline the Cacique's heart to Christianity, and he allowed himself to be baptised by the father, who then prevailed upon Alvarado to commute his sentence into that of hanging." The prisoner's son was graciously allowed to inherit his hanged father's property.

Alvarado next made for Guatemala City, whose inhabitants, as they were at enmity with the Utatlans, received the Spanish well, and sent ambassadors to them with a present of gold, at the same time declaring themselves vassals of the emperor, and expressing their willingness to serve, in Spain's behalf, against the other inhabitants. Alvarado, to prove their sincerity: asked for 2000 men to join his army; saying that, as he was unacquainted with the country, these reinforcements would be very useful as baggage-bearers, and in clearing the roads that had been barricaded by trees. Before long these men arrived. He had also added to his camp-followers a large number of prisoners, whom-after setting apart one-fifth for his Majesty of Spain - he had branded with red-hot irons, and divided 
among his troops. Let Castillo take up the tale again.

" Upon this Alvarado marched to Guatemala, where the inhabitants gave him a kind and hospitable reception. Here the men enjoyed some rest, and they congratulated each other on the success that had attended their arms, and now they thought with pleasure of the fatigue they had undergone. Among other things Alvarado declared to Father Almedo and his officers that he had not been in any battle where he considered himself in greater danger, than in the one they had recently fought with the tribes of Utatlan, who had combined excessive ferocity with uncommon bravery, and he considered that his men had done wonders on that occasion. 'It was the arm of God that was with us,' remarked Father Almedo, ' and that $\mathrm{He}$ may not desert us in future, let us appoint a day of thanksgiving to the Almighty and the Blessed Virgin, and celebrate a high mass, and I will preach a sermon to these Indians.'

" Alvarado and the other officers immediately fell in with this idea, and after an altar had been erected, the whole of the men made the communion, and high mass was performed with every solemnity. A great number of Indians were present on the occasion, to whom Father Almedo preached so many excellent things, and gave so many convincing proofs of the truth of our Holy religion, that above 30 of them became converts to Christianity. In the course of the two following days, they were baptised, and several others expressed a similar wish, when they found that the Spaniards made more of the converts than of the others. Upon the whole, there was nothing but rejoicing and happiness between the troops of Alvarado and the inhabitants of the place."

This curious scene comes as a refreshing change after the tales of horror and bloodshed that form the major 
part of Alvarado's story. I do not propose, therefore, to follow him in detail through the remainder of his campaign, the incidents of which are not very materially different from those already recounted. Alvarado's chief difficulty was, as it always has been, the mountainous nature of the country that prevented him from slaughtering the natives as indiscriminately as he had hoped to do. But he seems to have done fairly well on the whole, and it is gratifying to note that the Indians succeeded in getting a little of their own back upon the burner and brander of prisoners. This is the chief's account of the incident. As Castillo admits that the Indian arrows did very little harm, it may be that Alvarado exaggerates the seriousness of the wound, in order to unloosen more widely, on a future occasion, the purse-strings of his most Christian Majesty.

"When I had withdrawn for a quarter of a league into a place where we could all fight, I made my army face about; we attacked them and beat them so vigorously that there was a frightful slaughter, so that in a short time there was not one left alive ; they were so embarrassed by their arms that they would fall to the ground unable to rise. These arms are casaques of cotton threc fingers in thickness that came down to the feet. All those who fell were killed by the foot soldiers ; many of the Spaniards were wounded in the mutiny. I received an arrow in the thigh that went through it from one side to the other, and pierced the saddle ; I am crippled by it ; and have one leg shorter than the other by fully four fingers' length. I was forced to stay five days in the village to be attended to " (Alvarado's letter to Cortes).

Father Olmedo, meanwhile, was still busy proselytising among all those Indians who had sworn allegiance, or had otherwise escaped with their lives. "He ordered an altar with a cross to be erected, in front of which he regularly performed mass, and the inhabitants on these 
occasions imitated the Spaniards in all their religious ceremonies. Father Olmedo also placed on the altar an image of the Virgin Mary, which had been presented to him by Garay in his dying moments. This image was of such extreme beauty that the Indians became quite enamoured of it, and Father Olmedo explained what was meant by such an image, and how Christians prayed before it."

With Alvarado's graphic picture of Guatemalan volcanoes, we will leave these tales of the Spanish adventurers.

"We saw in the province a volcano more frightful than any known hitherto ; it throws flaming stones as big as a house, that break in falling, and cover all the mountain with fire. Sixty leagues farther on, we saw another volcano that threw up a frightful smoke that rose to the sky; this smoke covers half-a-league in extent; no one drinks the water of the streams that come down from this volcano, because they smell of sulphur; it gives rise in particular to a very fine river, which, however, is so hot that a company of my men, who had been inspecting the country, could not cross it. While looking out for an ambush, they found another cold river that joins the first. As the water at this junction is tepid, they were able to cross it." 



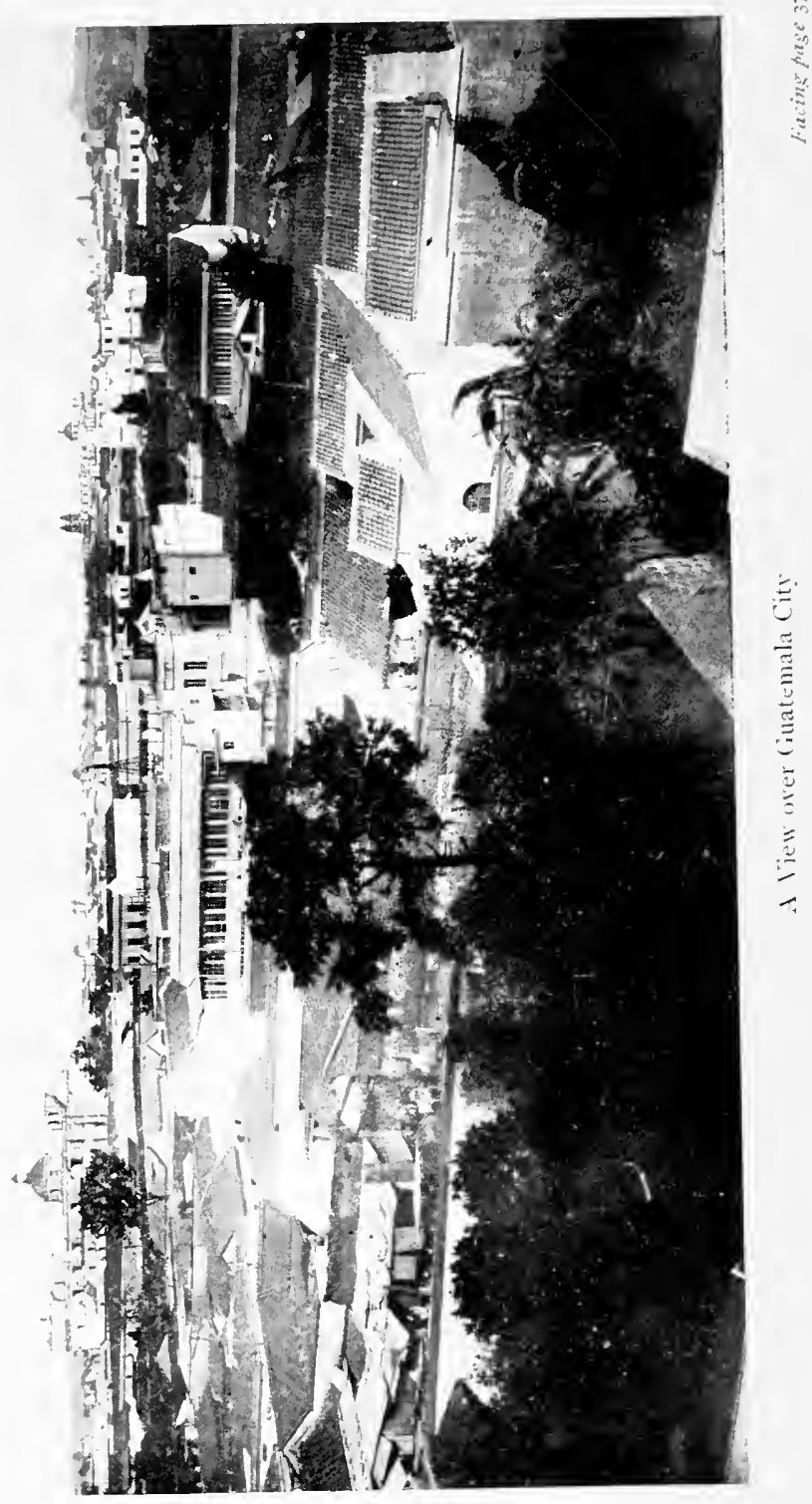




\section{CHAPTER III}

\section{THE SPANISH CONQUEST}

A TRAVELLER standing in the plaza of the little town of Coban will see, at the end of it, a great white church built in the florid bastard-Renaissance style of Central American architecture. This building owes its existence to the missionary efforts of Bartolomé Las Casas, Bishop of Chiapa, the "Apostle of the Indies," and to those of his companions of the Brotherhood of St Dominic. Las Casas is the most important witness we have-for he was an eye-witness - of the barbarities of the Spanish adventurers, which he described in his very interesting book, "An Account of the First Voyage and Discoveries made by the Spaniards in America. Containing the most Exact Relation hitherto published, of their unparallel'd Cruelties on the Indians, in the destruction of above forty millions of people."

These barbarities, according to the curious woodcuts printed in the English translation, of I699, included burning, dismembering, the roasting alive of children, the hanging of children by the neck to their mother's waists, hanging above a fire, disembowelling, flogging, impaling on stakes, and mauling by dogs. Others were buried alive, thrown from hill-tops, shot to death with arrows while tied to a post, and so forth. If the reader has not yet supped full of horrors, he may like to have some extracts from the Spanish missionary's story. Thus Las Casas concerning Guatemala:

" The Spaniards signalised their entrance into this Kingdom by divers Massacres, tho' the King came to 
meet 'em in his Chain of State supported by his Slaves, follow'd by a great number of his Lords, and with Trumpets, and Drums before him, to give the greater Testimony of Joy ; he show'd 'em all the Courtesy and Civility in the world, manifested a great deal of Kindness in readily supplying ' $\mathrm{em}$ with plenty of Provisions, and gave 'em whatever they could reasonably desire.

"The Spaniards lodged without the city the first night, thinking they should not be secure enough in a place so well fortified. The next day, they engag'd the Prince of the place to come out to 'em with the greatest part of the Persons of Quality, obliging to bring with them a certain quantity of Gold. The Indians made answer that it was impossible for them to do what was requir'd, because their country did not yield this Metal. However, this refusal so mov'd the Indignation of the Spaniards, that for no other offence, without any formal Process, they cast 'em all alive into a great Fire. The most considerable Inhabitants of the Provinces, seeing their Masters so cruelly treated, only because they gave not the Spaniards all the Gold they demanded, retired with all speed into the Mountains, ordering the common people to submit to the Spaniards as their Masters, and giving them a strict charge by no means to give the least notice of the places where they were gone to hide themselves. Abundance of these poor People came accordingly to the Spaniards, begging of 'em to receive them into the number of their Servants, and promising to serve 'em faithfully as far as they were capable. The Spanish Commander roughly assured 'em, that he would not so receive 'em, but cut 'em to pieces without Mercy, unless they would discover the places whither their Masters were retreated; the Indians replied, that they did not know ; however, they readily offer'd themselves, their Wives and Children to their Service; and said, they would continue in their Houses expecting their Orders ; they further told 'em, they might treat 
'em as they pleas'd, 'twas in their power either to kill 'em, or to save 'em alive to employ 'em in their Service. The Spaniards, upon this went into their Villages and Towns, and found these poor Indians with their wives and Children busy at their work, and in great security, believing they had no need to fear the Spaniards would attack 'em ; yet these bloodthirsty men massacred 'em without pity. After this they went to another great Town, the Inhabitants of which, confiding in their Innocence, thought themselves in no great danger; but this whole Town was destroyed in less than two hours, and the Massacre was so general, that no Age, nor Sex, nor Quality met with Pity, but all were put to the Sword, unless such as fled before the arrival of the Spaniards.

The Indians at length finding it impossible either by their Patience, their Submissions, or their Presents, to soften the cruel and savage Temper of the Spaniards, who cut their Throats without any Reason, or any sentiment of Pity, resolv'd to get together in a body, and take Arms to defend themselves, for seeing Death was inevitable to 'em, and become a necessary evil, they chose rather to die with Weapons in their hands, thereby to sell their lives at as dear a rate as they could, and to revenge themselves as much as possible on their Persecutors, than to suffer their Throats to be cut like Sheep without making any resistance. They wanted effectual Arms, they were quite naked, and knew their strength was much inferior to that of their enemies; they had no Horses, nor did they understand the use of 'em in Battle ; they had to do with a furious and warlike Enemy that gave 'em no quarter, and design'd nothing but their Extirpation. They therefore thought it necessary to use Stratagems; it came into their heads to make Pits up and down the ways by which the Spaniards were to pass, and to cover 'em with Straw and leaves that they might not be perceiv'd, that so their 
Horses might fall in 'em, and break their Neck or Legs. Some of the Spaniards were two or three times taken in these Traps, but afterwards took care to avoid 'em, and resolv'd to cast all the Indians they could take into these Pits, whether Men, Women, or Children, of what Age or Condition soever; they threw in women big with Child, and old Men as well as others, till they had quite fill'd 'em. It was a most lamentable sight to see some Women impaled together with their Children, and so exposed to the fury of greedy dogs, and others run through with Lances and Halberts. They burnt one of the greatest Lords of the Country with a gentle Fire, and insultingly told him 'twas to do him the more honour, that they put him to death after this manner. In the province of Cuzcatan there came 300,000 Indians to the Spaniards laden with Indian Poultry, and all other Provisions the Country would afford in great abundance. After they had received these Presents, the Spanish General order'd his Men to choose as many Indians as each of 'em desired for their Service, while they remain'd in that Province. Accordingly one took a hundred, another fifty, as they had occasion to carry their Baggage. These poor Wretches serv'd them with all their care and diligence, and were even ready to worship 'em. At length the General demanded of 'em a great quantity, of Gold, that being the main business for which he came ; they with a great deal of Humanity and Submission, told him they would readily give him all they had, which was made of Copper gilt, and which they took for pure Gold by the looks of it. The General soon made trial of it, and finding what it was, addressed himself to the Spaniards in those lines: 'We must carry Destruction with us [says he] through all this Country, seeing there's no gold to be found; Every one of you may kcep the Indians you have choscn for your perpetual Slaves; You may load 'em with Chains, and brand 'em with the mark of their Slavery'; Which was 
immediately done; For they printed the King's Arms with a hot iron upon all they could take.

"After this Expedition, the Spaniards return'd to Guatemala, where they built a City; but God was pleas'd by his just judgment utterly to overthrow and destroy it! They kill'd all without Mercy whom they suppos'd to be in a condition to incommode 'em by their Arms, and the rest were condemn'd to Slavery. They extorted from 'em a Tribute of Boys and Girls, and sent 'em into Peru to be sold. The other Inhabitants of this Kingdom, which is roo leagues in length, were likewise destroy'd. Thus one of the most pleasant and fruitful Countries on the World was reduc'd to a melancholy desert. The Governor himself has freely confess'd that this was the most populous Country in the West Indies, not excepting Mexico itself, which is certainly true. In this noble country the Spaniards have destroy'd no less than four or five millions of Men in fifteen or sixteen years, and continue every day to treat those that remain after the same manner. These inhuman creatures were wont when they declar'd War against any City or Province, to bring with 'em as many of the conquer'd Indians as they could, to make 'em fight against their own Country-men ; sometimes they had fifteen or twenty thousand of these new Subjects among 'em. But because they were not able to furnish 'em with all necessary Provisions, they allow'd 'em to eat those other Indians whom they took in War, so that in their Camp they had shambles stored with human Flesh. Infants were kill'd in the night, and then boiled and eaten; Men were slaughtered like Beasts, and their Legs and Arms dress'd for food ; for the Indians like the taste of those Parts better than others.

"Many of the Indians were worn out with carrying the tackle of the Spanish Ships, which they would needs have brought from the North to the South Sea, which 
is I3o leagues distant. They made 'em carry Anchors of a great weight all this long way; they laid great Guns upon the Naked Backs of these poor Creatures, under the weight of which they were not able to stand; so that the greatest part of 'em dy'ed by the way, not being able to cndure these Fatigues. To increase their Misery, they divided their Families, taking Husbands from their Wives, and Wives from their Husbands; their Daughters were taken from 'em, and given to the Seamenand Soldiers to satisfy their Lust, and to appease their murmuring. They fill'd the Ships with Indians, and suffer'd 'em to perish with Hunger and Thirst, because they would take no care to furnish 'em with Necessaries. But to give a particular account of all their Cruelties would require large Volumes, the view of which would astonish all that should have the curiosity to look into 'em."

It is pleasant to be able to turn now from these Spanish murderers, to follow, for a moment, the fortunes of Las Casas, this bold spokesman of the Indians. His doctrines, naturally enough, were vehemently opposed by his fellow-countrymen, whose position, although the Quichés were more than half subdued, was not wholly secure. Indeed Tuzulutean was already known as " La tierra de guerra," the land of war. The Spaniards, therefore, decided to give Las Casas an opportunity to practise what he preached, and the then governor, Alonzo Maldonado, wrote to Las Casas promising the Indians five years of absolute freedom from molestation, provided that they could be induced to accept the Catholic faith, to acknowledge the Spanish crown, and to pay a moderate tribute.

Las Casas at once accepted the challenge, and with the help of his three brethren, Rodrigo de Ladrada, Pedro de Angula, and Luis Cancer, they composed; in the Quiché language with which they were familiar; 
verses setting forth the fall of man, and the principles of the Christian faith. These verses they taught to four Indian traders who were in the habit of journeying in those parts, instructing them to chant the verses to the accompaniment of native music. The music, the verses, the story that they told, all worked with magical effect upon the impressionable and superstitious natives; but when the cacique asked for further information and details, he was told that none save the padres could give them. "Who are these padres?" said the cacique.

"The padres," replied the traders, "dress in black and white garments, they wear their hair cut in the form of a wreath, they eat no meat, they desire neither gold nor cloaks, nor feathers, nor cacao, they marry not, yet live chaste lives, they sing praises to God, day and night, they possess lively images before which they kneel in prayer; and they alone can explain the meaning of the verses."

It was soon arranged that the younger brother of the cacique, a youth twenty-two years old, should return with the traders to Guatemala, to arrange for the teaching of the people, and secretly to find out whether or not the traders had been romancing concerning the character of their mysterious padres. He went, was well received, and brought back a favourable report. The conversion of the Quichés had begun. Not long after, Las Casas himself visited Don Juan, as the cacique was called, and was welcomed, although there had been much grumbling among the more stubborn devotees of the old gods, and the first Christian Church had been burnt to the ground. One great difficulty existedthe distribution of the natives, in tiny hamlets, over so vast an extent of country, made proselyt ising and visiting matters of extreme difficulty. Las Casas, therefore, sought to induce the Indians to live in towns, a measure which, though perhaps good for the souls, was harmful 
to the bodies of a race whose primitive habits and want of cleanliness laid them open to all the dangers of disease that threaten the town-dweller.

Las Casas and his faithful brethren, however, had done good work. He himself, when he visited the Province of Coban, gave testimony to the excellence of the native government, and to the comparative absence of the worst Indian abominations. Let us remember, too, that through the influence of the Dominican fathers the name "Land of War" gave way to that of "Vera Paz," "The Land of True Peace." 

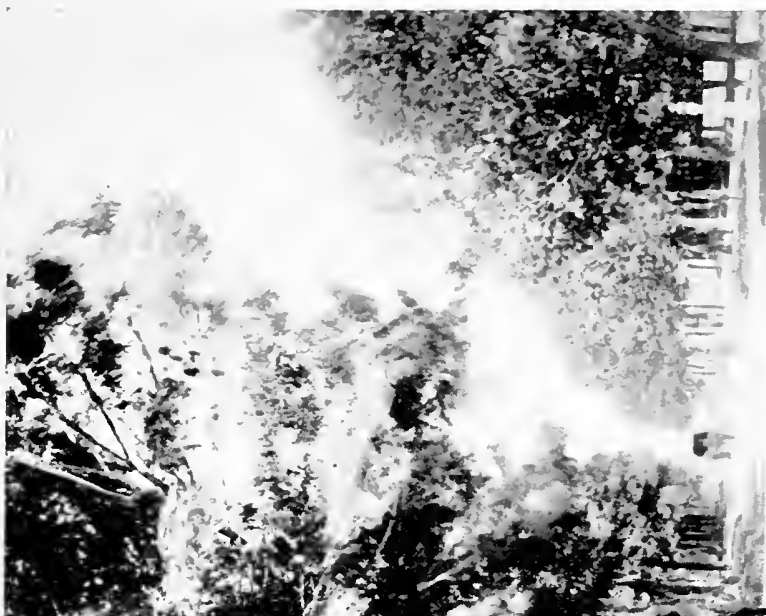

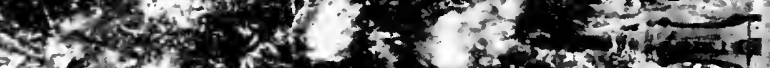

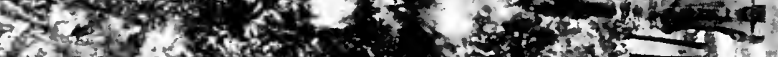

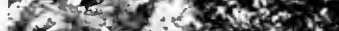

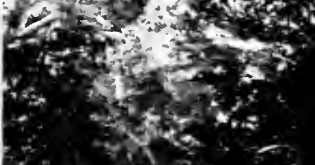

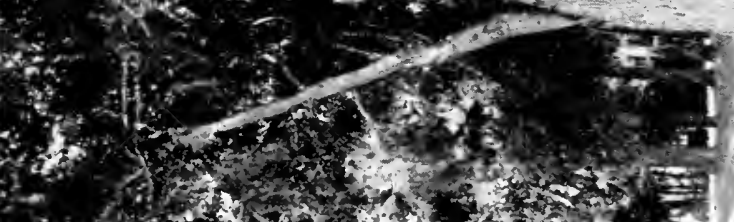

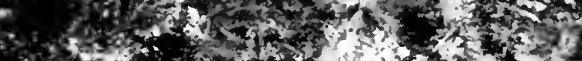
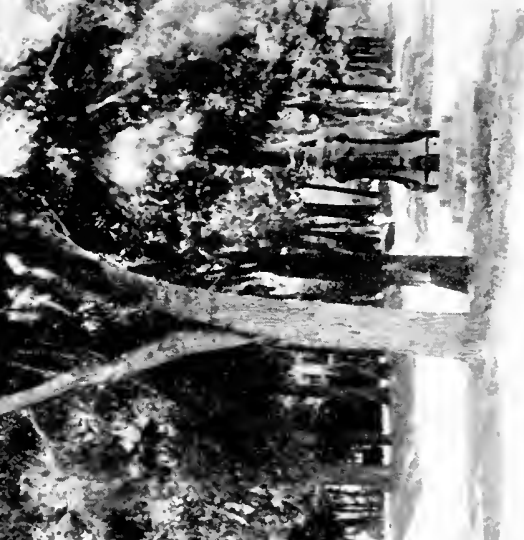

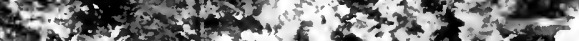

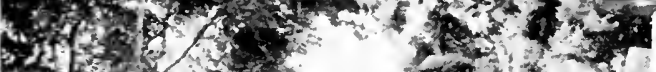
P. f.

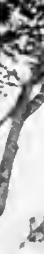
a.

¿rip

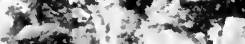
ras in

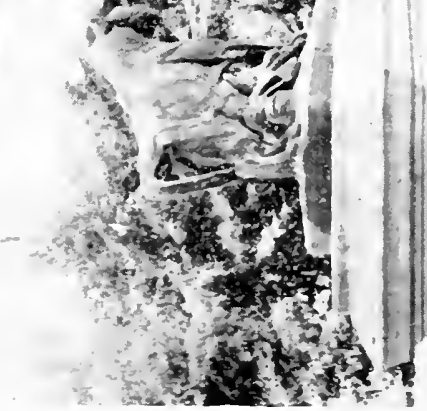





\section{CHAPTER IV}

\section{LATER HISTORY OF GUATEMALA}

ENOUGH has been said concerning Spanish methods in Guatemala to show that they were no better, no more deserving of permanent success, than in the case of other countries of America. It is one long story of oppression, corruption, monopoly, culminating in risings of the Indians that were ruthlessly suppressed. This procedure could be, and was, carried on with immunity for a century or two ; but, gradually, as generations of American-born Europeans began to rise, a national spirit was born and grew with them, until it became evident that the comparatively simple problem of suppressing native Indians must henceforth take a secondary place. The time had come for the Spanish rulers to satisfy a Guatemalan nation. With the opening of the nineteenth century was heard the first mutterings of storm.

Napoleon, then at the height of his power, was one of the principal means of breaking down the half-superstitious fears and reverence with which Guatemalans had regarded, hitherto, their Spanish masters and the Spanish rule. The French Emperor's brother Joseph was crowned King of Spain, after the detention of the then reigning Monarch, Ferdinand VII., at Bayonne. These acts of violence were an incentive to Guatemalans to protest against tyranny that was fast becoming unendurable. But, though the spirits of discontent and of mistrust were in the air, no man arose of character sufficient to compel confidence. Gradually the demand 
of the natives for a voice in the management of their own affairs became more clamorous. Spain made promises of reform : they remained unfulfilled. Mutual suspicion deepened. Spanish spies were everywhere. Mexico gave a lead, when, on I5th September I8Io, Hidalgo issued a pronunciamento-the first of many that were to follow-declaring the end of Spanish rule in Mexico. Unrest increased; the weaker began to despair. By the end of the year I8II, pronunciamentos had been appearing right and left in Guatemala. Protest began to translate itself into action. Even promises of eighty days indulgence, made by the archbishop to those who would undertake to hold aloof from the revolutionaries, had little effect, except among the most ignorant and degraded. The educated were not to be so cheaply bought off. Nor could the malcontents be as easily suppressed by force. Revolutions were in progress in Mexico and elsewhere. Spain had her hands more than full; soon they were to be empty. For another ten years the struggle continued, each attempt to blow out the flame of revolt acting only as a force draught to a kindling fire. In I8I3 came the Butler conspiracy, thwarted by the betrayal of its leader. At last, in I8I4, Spain, through her representative, Bustamente, proclaimed a constitution. But it was too late. Spanish constitutions, thought Guatemala, will go the way of Spanish promises. So the Revolution sputtered on, always gaining adherents, until, in I82I, the Spanish representative, Senor Gavina Gainza, went over to the patriots. Immediately, there were busy scenes on the plaza of Guatemala City, cheers for freedom, groans for Spain, a crowded meeting in Government House, from which the anti-revolutionists thought it wiser to withdraw while they could do so safely. On the following day was proclaimed throughout the city an Act of Independence, declaring Guatemalans a free and independent nation, and inviting people to elect, 
and send to a national congress, one representative for each 15,000 inhabitants. So it was done, and the rule of Spain, that had endured from $\mathrm{I}_{524}$, nearly three hundred years, was at an end in Guatemala. Other states, too-Honduras, San Salvador, Nicaragua, and Costa Rica-were soon to follow that example.

But serious difficulties still cumbered the path of the emancipated state. Even an act so brave and righteous as the abolition of slavery-decreed forty years before the United States dared to follow the example-brought about practical difficulties, since it necessarily ended the exploitation of the natives, by whose forced labour the priests had erected their many churches and convents, and who had done useful work in the repair of roads, bridges, etc. ; that, in a tropical country, need constant attention and labour.

The state soon divided itself approximately into two parties, the Conservatives or Central Groups, and the Liberals or Democrats. To the former went the majority of the clergy, the aristocracy, such as it was, those who enjoyed monopolies, or privileges, or who, for other reasons, were fundamentally opposed to change. Most of the more enlightened, and many others, merely because they had nothing to lose, joined the Progressives. At first Guatemala, in common with the otner freed states, having no very definite policy, and beset with dangers, looked about for a strong ally. Her eye fell, naturally enough, upon Mexico, and the idea of union with that larger power soon became popular. Negotiations to that effect were entered into with Iturbide, the Emperor of Mexico, who favoured the scheme. On $5^{\text {th }}$ January $\mathrm{r} 822$ annexation was decreed, and Guatemalans were given all the rights of Mexican citizens, including the right to be leavily taxed. But to thus be swallowed up was not Guatemala's destiny. The new union did not long survive the fall of Iturbide, and, in I823, the Asamblea Nacional Constituyente met, 
and eventually proclaimed, in $\mathrm{I} 825$, after a session of nearly two years, a new Federal Constitution modelled upon that of the United States.

Before long, however, trouble arose between the local and federal authorities in Guatemala City, and on the I3th of October I826, the Vice President Flores, who had withdrawn to Quezaltenango, was murdered, stripped, and mutilated in the Parish church of that city, where he had taken refuge, by a mob of native women incited thereto by the fictions of a Spanish priest.

The following account of the murder is given by Stephens :-

"Flores, the vice-chief of the State of Guatemala, a Liberal, had made himself odious to the priests and friars by laying a contribution upon the convent at Quezaltenango; and while on a visit to that place the friars of the convent excited the populace against him, as an enemy to religion. A mob gathered before his house, with cries of 'Death to the heretic !' Flores fled to the church; but as he was entering the door a mob of women seized him, wrested a stick from his hands, beat him with it, tore off his cap, and dragged him by the hair. He escaped from these furies and ran up into the pulpit. The alarm bell was sounded, and all the rabble of the town passed into the plaza. A few soldiers endeavoured to cover the entrance to the church, but were attacked with stones and clubs; and the mob, bearing down all opposition, forced its way into the church, making the roof ring with cries of 'Death to the heretic !' Rushing toward the pulpit, some tried to unhinge it, others to scale it; others struck at the unhappy vice-chief with knives tied to the ends of long poles; while a young fiend, with one foot on the mouldings of the pulpit, and the other elevated in the air, leaned over and seized him by the hair. The curate, who was in the pulpit with him, frightened at the tempest he had assisted to raise, held 



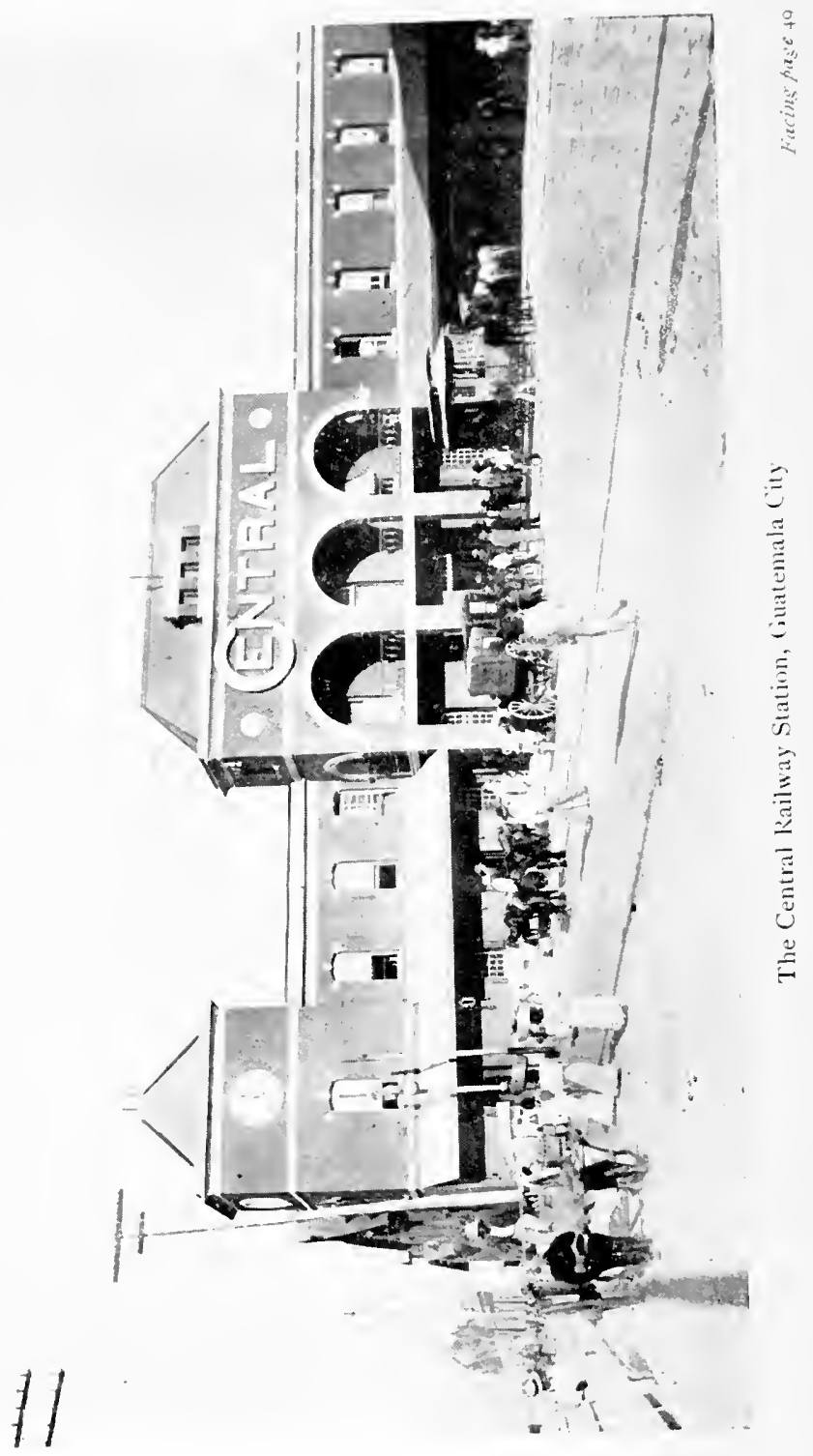


up the Holy of Holies, and begged the mob to spare him, promising that he should leave the city immediately. The unhappy Flores, on his knees, confirmed these promises, but the friars urged on the mob, who became so excited with religious phrensy, that after kneeling before the figure of the Saviour, exclaiming, 'We adore thee, O Lord, we venerate thee !' they rose up with the ferocious cry, 'but for thy honour and glory this blasphemer, this heretic must die !' They dragged him from the pulpit across the floor of the church, and in the cloisters threw him into the hands of the fanatic and furious horde, when the women, like unchained furies, with their fists, sticks and stones, beat him to death. His murderers stripped his body, leaving it, disfigured and an object of horror, exposed to the insults of the populace, and then dispersed throughout the city, demanding the heads of Liberals, and crying, "Viva la Religion!' "'

The murder was followed by a furious outbreak of religious fanaticism. The republic of San Salvador sent troops into Guatemala to restore order ; but their attack on the capital failed, and only a desultory war resulted.

A new Central American hero was now about to appear, in a land that urgently needed a strong and righteous man to lead it. This was Francisco Morazan, born in I799, in Honduras, to a French father by a native creole woman-a brave, manly, impetuous, and, on the whole; human personality, frank and open in manner, genuinely patriotic, and in private life a quite unimpeachable character. A further outbreak of revolution in Guatemala brought Morazan, then a senator of Honduras, to Guatemala City, with a force of about 2000 men, on behalf of the malcontents. After a battle lasting three days, the capital capitulated, the invaders entered the city in triumph, suppressed the leaders of the opposite party, and incidentally the convents also. 
He was ever able to say, at the time, that, for a period at least, in spite of many grievances, " no one was put to death nor had money extracted from him "- - very unusual sequel to the triumph of a revolutionary leader.

General Morazan was elected President of Guatemala in September I830. During the ten years for which his party held office, he seems to have administered the state vigorously and justly.

The following sketch of General Morazan is from the most interesting early chapters of Stephens' "Incidents of Travel," in which he recounts some thrilling episodes of Central American revolutionary history:-

"General Morazan, with several Officers, was standing in the corridor of the cabildo; a large fire was burning before the door, and a table stood against the wall, with a candle and chocolate cups upon it. He was about forty-five years old, five feet ten inches high, then with a black moustache and week's beard, and wore a military frock-coat, buttoned up to the throat, and sword. His hat was off, and the expression of his face mild and intelligent. Though still young, for ten years he had been the first man in the country, and eighth president of the republic. He had risen and had sustained himself by military skill and personal bravery; always led his forces himself; had been in innumerable battles and often wounded, but never beaten. A year before the people of Guatemala had implored him to come to their relief, as the only man who could save them from Carrera and destruction. . . . From the best information I could acquire, and from the enthusiasm with which I had heard him spoken of by his officers, and, in fact, by every one else in his own state, I had conceived almost a feeling of admiration for General Morazan, and my interest in him was increased by his misfort unes."

Meanwlile the struggle between clericals and anticlericals was being waged with increasing bitterness. Many years passed before the people were able to free 


\section{LATER HISTORY OF GUATEMALA 51}

themselves from the yoke of the Church ; and the light of freedom, as it came, did but bewilder them for a time. Morazan, for all his abilities and integrity, was hardly a strong enough man for the task he had undertaken. However, he did his best, and to him are due some valuable measures dealing with education and freedom of conscience in religious matters - a toleration which naturally more and more incensed the Church party, some of whom took advantage of an epidemic of cholera, in I837, to suggest to the ignorant and suspicious native mind that the waters had been deliberately poisoned. Revolt immediately followed, and some unfortunate medical men found themselves compelled to commit suicide by swallowing their own medicines.

Now another individual, destined to play a prominent part in Guatemalan history, was about to emerge into the light of fame. This was "Protecting Angel Rafael," as some of the priests called him, otherwise Rafael Carrera, a low-born Indian, the son of a market woman, whose early developed love of adventure, courage, determination and violence had placed him at the head of a rabble army numbering among its ranks some of the outlaws, robbers, murderers, and other choicest scoundrels that the country could furnish. The catalogue of their weapons, from the knife at the end of a pole, to a rusty musket, reminds one of the stories of the night before Sedgemoor.

The Government, in great consternation, offered I500 dollars, two caballarias of land, and a free pardon for any crimes committed, to any who would bring them the body of Carrera, dead or alive : then, when this device had failed, they adopted the futile policy of buying off Carrera and his army. But they had mistaken their man. Carrera might be bought off-but he would not remain off. He returned, to be constantly beaten, and as constantly to retrieve his fortunes. Fortune was with the extraordinary man. 
At last Morazan was forced to flee from Guatemalanever to return.

Stephens' account of Carrera's entry into Guatemala City makes very picturesque and interesting reading. One can hardly believe that we are in the nineteenth century. The leader was on horseback at the head of his rabble, with a green bush in his hat, which was hung round with pieces of dirty cotton cloth, and covered with pictures of the saints. A spectator, familiar with all the scenes of terror that had taken place in the city, said that he had never felt such horror as was inspired in him by the entry of this mass of barbarians, all with green bushes in their hats, a moving forest, armed with every known and unknown weapon of offence, and followed by two or three thousand women with sacks for carrying away the plunder. They entered the plaza shouting "Death to the foreigners!" At sundown that shout gave place to the "Hymn to the Virgin," and Carrera entered the cathedral. After him trooped the Indians, who, though mute with astonishment at the magnificence around them, proceeded to set up around the altar the uncouth images of their village saints. Monreal broke into the house of General Prem, and emerged bearing a uniform coat, richly embroidered with gold, into which Carrera, still wearing his straw hat and green bush, slipped his arms. A watch was brought to him, but he did not know the use of it. Was ever such a sight seen since the days of Alaric and his Goths? We should like to tell, had we space, how Carrera was constantly beaten, as constantly escaped. How his followers were scattered, his best men taken and shot ; how he himself was penned up, and almost starving, on the top of a mountain, with a cordon of soldiers at its base, only to escape by the remissness of the guard; how, at last, he came to power in a city which was exposed to almost equal danger, whether he or Morazan came out on top. 


\section{LATER HISTORY OF GUATEMALA 53}

Stephens mentions a little circumstance, as explaining the position of things. Carrera's mother, an old market woman, had died, and although, in those days of cholera, burial in the churches was forbidden, Carrera signified his pleasure that his mcther should be laid in the cathedral. And buried in the cathedral she was-by a government that would spare no effort to keep in good temper a leader subject to violent outbursts of passion, the absolute master and King of Guatemala, called by fanatic Indians, "El Hijo de Dios," "The son of God," and " Nuestro Señor," "Our Lord." The following is Stephens' account of his interview with the noted chief :

"Carrera was living in a small house, guarded by sentinels, in a retired street. Along the corridor was a row of muskets with shining barrels.

"When I entered the room he was sitting at a table counting sixpenny and shilling pieces. Colonel Monte Rosa, a dark Mestitzo, in a dashing uniform, was sitting by his side, and several other persons were in the room. He was about five feet six inches in height, with straight black hair, an Indian complexion and expression, without beard, and did not seem to be more than twenty years old. He wore a black bombazet roundabout jacket and pantaloons. $\mathrm{He}$ rose as we entered, pushing the money on one side of the table, and probably out of respect to my coat, received me with courtesy and gave me a chair at his side. My first remark was an expression of surprise at his extreme youth; he answered that he was but twenty-three years; certainly he was not more than twenty-five, and then as a man conscious that he was something extraordinary, and that I knew it, without waiting for any leading questions, he continued that he had begun (he did not say what) with thirteen men armed with old muskets, which they were obliged to fire with cigars; pointed to eight places in which he had been wounded, and said that he had three balls then in his 
body. At this time he could hardly be recognised as the same man, who, less than two years before, liad entered Guatemala with a horde of wild Indians, proclaiming death to strangers. Indeed, in no particular had he changed more than in his opinion of foreigners, a happy illustration of the effect of personal intercourse in breaking down prejudices against individuals or classes. . . Considering Carrera a promising young man, I told him he had a long career before him, and might do much good to his country; and he laid his hand upon his heart, and with a burst of feeling that $\mathbf{I}$ did not expect, said he was determined to sacrifice his life for his country. With all his faults and crimes none ever accused him of duplicity, or of saying what he did not mean, and perhaps, as many self-deceiving men have done before him, he believed himself a patriot. . . He could not fix his thoughts upon anything except the wars and Morazan; in fact he knew of nothing else. He was boyish in his manners and manner of speaking, but very grave; he never smiled, and conscious of power was unostentatious in the exhibition of it, though he always spoke in the first person of what he had done and what he intended to do. . . My interview with him was much more interesting than I had expected; so young, so humble in his origin, so destitute of early advantages, with honest impulses, perhaps, but ignorant, fanatic, sanguinary, and the slave of violent passions, wielding absolutely the physical force of the country, and that force entertaining a natural hatred to the whites. At parting he accompanied me to the door, and in the presence of his villainous soldicrs made me a free offer of his services."

Stephens gives most vivid accounts of the quick changes in the fortunes of the parties in these days. During one year Morazan is sent for as the only one who can save them from disaster at the hands of Carrera; 
a year later the positions are exactly reversed. Carrera's triumphal entry into Guatemala City was made beneath arches and flags, to salvos of cannon and military music. By Carrera's side rode the secretary of the Constituent Assembly; then followed the prisoners, tied together with ropes, among them General Guzman, a friend of many of the principal inhabitants, the very man whom they themselves, a year before, had summoned, with piteous entreaty, to their aid. The general was seated sideways on a mule, his feet tied under him, and his face so bruised, swollen, and disfigured by stones and blows of machetes, that he was quite unrecognisable.

Soon after this, Morazan's army attacked the city, and there ensued a desperate battle, in which Morazan and his army were utterly routed. Finally, after suffering heavy losses, his whole force was penned in the plaza by an immense body of Indians, who fired upon him from all corners. At last, from want of ammunition, the fire slackened, and finally ceased. The neighbouring streets were blocked with dead men; from every corner the Indians, unable, for the moment, to kill, kept up against the patriot and his men a running fusillade of obscene jests and abuse. Carrera; meanwhile, was making cartridges with his own hands.

At sunset the mob of Indians who had invaded the city fell on their knees. In mighty chorus rose the "Salve" or "Hymn to the Virgin." Morazan heard it, and for the first time realised and expressed a sense of the awful danger he was in. The prayer was followed by terrific shouts of "Viva le Religion! Viva Carrera! Y muera el General Morazan!" The firing recommenced. At two o'clock in the morning Morazan made a desperate effort to cut his way out of the plaza, but was repulsed with great slaughter of his men, including forty of his best officers and his eldest son. At last, by concentrating his fire on 
certain points, and throwing his powder into the fountain, he took advantage of the confusion to fight his way out, with $500 \mathrm{men}$, and by twelve o'clock had reached Antigua.

A word or two on Morazan's subsequent career will not be out of place. He soon became involved in the political troubles of Costa Rica, fighting, as usual, for freedom and justice; but he was defeated, captured by treachery, and condemned to immediate death. On the morning of I2th September I842, he boldly faced the firing squad, and himself gave the word of command. "Posterity will do me justice" were his last words. He did not misjudge posterity.

The scenes that followed Carrera's victory are worthy of the Septembriseurs of the French Revolution. Carrera's soldiers, in joyous anticipation of to-morrow's massacre, fired cartridges all night. With daylight the slaughter began. Colonel Arias, lying on the ground with one of his eyes out, was bayoneted. Marescal, hidden beneath the cathedral, was dragged out and shot. The fugitives were brought, in little groups of from three to ten, into the plaza, where Carrera stood. As the ruffian's lifted finger pointed out this man or that, the wretched victim was removed a few paces from his judge, and shot. Major Viera was drinking chocolate in the housc of a friend where he had taken refuge, when he was sent for. His host; Mr Hall, delivered him up, with a special recommendation to mercy. A moment later Mr Hall, a few paces from his own door, found Viera lying on his back, dead. During the morning vagabond soldiers overran the city, begging money, pointing their muskets at the heads of passers-by, to show how they shot the encmy, and boasting how many they had killed.

This Carrera-unspeakable rascal and brigand, or "Son of God," according to the point of view you may choose to take-was now, in this year I839, the first 


\section{LATER HISTORY OF GUATEMALA 57}

man in the country; but he was not formally elected president until I844. After a period of retirement, he was made president for life, in 1852 , a position that he retained until his death, which, most inappropriately, took place in his bed, on the r4th of April I865.

Meanwhile his bust, with the legend, " $R$. Carrera Fundador de la Rca de Guatemala," had adorned the coinage of this country. ${ }^{1}$ The body of the original lies in the metropolitan church in Guatemala City.

Carrera was followed in the Presidental Chair by one Vicente Cerna, a religious fanatic, whose very moderate abilities appear to have been devoted mainly to the support of the clerical party. Certainly he was quite incapable of keeping the Indians and other malcontents under control; consequently his rule was marked by a series of insurrections, of which the most serious, perhaps, was that conducted by Senapio Cruz, a typical though corpulent brigand, who, from the security of mountain fortresses, waged a guerrilla warfare upon the Government monopoly. His efforts were worthily supported by Miguel Garcia Granados, and J. Ruffino Barrios, the latter of whom was destined to play a great part in Guatemalan history.

In December I869 a rebel army, that, as it crossed the country, had swelled from twenty-five men to a considerable force, approached the capital, whose inhabitants quivered with fear; until the news came that the invaders had been routed, and that the head of Cruz, without his body, would soon be within the town. Photographs of this trophy could be had in the shops a few days later, at the not unreasonable figure of fifty cents. With Granados, however, President Cerna, as became a man of piety, dealt gently. The revolutionary was merely banished; but, following the example of Romeo, Bolingbroke, and many another famous unfortunate, did not long consent to be so.

${ }^{1}$ The head on this coin is distinctly of the negro type. 
He invaded Guatemala with a small army, and was at once joined by General Barrios. The national army, headed by Cerna in person, met the invaders on the plain between Quezaltenango and Totonicapan, where Cerna was repulsed, only to be finally defeated at Chimaltenango and San Lucas, whence he fled into Honduras.

On 3oth June I870 Granados was elected president, though the real power was always wielded by his ally and superior, General Barrios, through whom several reforms were accomplished, including the freedom of the Press, the abolition of the aguardiente monopoly, the banishment of the order of Jesuits, and, in the following year, of the Franciscans, Capuchins, and Dominicans. Thirty years of Religious rule in Guatemala, says Rancroft, had produced only "two hundred lazy and stupid monks, two hundred almost useless nuns, one archbishop, two bishops, fifteen vicars and canons, and a foreign debt of five million dollars." 1

Barrios, who succeeded Granados in 1872 , was, by common consent, a stronger, more enlightened, and further-sighted man than any of his predecessors. $\mathrm{He}$ was resourceful, too, and possessed a quality invaluable to success in his position-an iron will. In disposition he was by nature sympathetic and affectionate, though cold and repellent with those whom he distrusted. His vengeance was swift and certain; his treatment of political enemies harsh in the extreme. He thought and acted with great rapidity. His work, which did more for Guatemala in a few years than that of others had accomplished in fifty, included, besides the reforms above mentioned, the construction of a new institution, the encouragement of education, and the confiscation of Church property for public uses. He encouraged the development of 1 Ousted Winter, p. I88: 


\section{LATER HISTORY OF GUATEMALA 59}

the country's resources; he subsidised the construction of railways, roads and telegraphs; he encouraged missionary effort, and the observance of the Sunday ; and he allowed the United States Presbyterians to open a Sunday school in the capital.

His autocratic and somewhat drastic methods naturally aroused bitter opposition in certain quarters. A plot was discovered, and seventeen of the leaders were executed in the plaza of Guatemala City. That summary procedure did not end the trouble; for one evening the president, while walking with some friends through the little garden of the theatre, found himself face to face with a fuse sparkling on a bomb. He stooped, picked up the infernal machine, extinguished the fuse, and, turning to his companions, remarked calmly: "The rascals don't even know how to kill me."

One of the great principles of Barrios' policy-an idea much strengthened by a visit to Europe, and by two visits to the United States, where he was very well received-was to consolidate the comparatively small neighbouring republics into one great, Central American federation. Nicaragua and Costa Rica opposed the idea ; but, encouraged by the apparent consent of the presidents of Honduras and San Salvador, Barrios issued, on the 28th of February I885, a proclamation declaring the federation an accomplished fact, with himself as temporary, supreme, military chief. San Salvador at once openly opposed the scheme, and a deadlock ensued. Barrios proceeded immediately to invade the country, with the result that he was shot dead from an ambush. The body of the great president was taken back for burial in Guatemala City, and the project of federation was at an end, though the decree was not formally withdrawn until after the election of the next president, Manuel Lisondro Barillas.

This man, a well-meaning though somewhat weak 
individual, served one term of office, and then, on the election of a relative of Barrios in his stead, retired in dudgeon over the border, and began the usual guerrilla warfare of the revolutionary. He had, however, been well checked, before two knife-thrusts in the neck, delivered by a young Guatemalan, in a tramcar in the city of Mexico, in April 1907, abruptly terminated his career.

Barillas was succeeded by the present occupant of the presidential chair, Manuel Estrada Cabrera, whose name has already added lustre to Guatemalan history, and who, perhaps, may fulfil the hopes expressed of him to Mr Winter: "Cabrera is a wonderful man. He will do for Guatemala what Diaz has done for Mexico." 1

The present president, though lacking somewhat in qualities of the higher diplomacy, has done much to carry on the good work of his eldest predecessor. Not the least of his virtues is, that he is an active supporter of the Central Amcrican Peace Conference, that valuable movement promoted by the United States, towards the establishment of a better understanding between these neighbouring republics of New America.

I have purposely refrained from giving the reader more than a compressed account of the various political incidents that have taken place since the Proclamation of Liberty. During its young days Guatemala suffered from many errors of administration; but they were the stepping-stones to a better order of things. The rapidly growing population had never been educated, even in the most rudimentary subjects, and it was only natural that they knew not how to use the power which had been suddenly placed in their hands. The Reform Movement separated the Church from the State, and sowed the seeds of a system of general education; but it was left to the last two rulers to lay the foundation

${ }^{1}$ Winter's "s Guatemala," p. I98: 


\section{LATER HISTORY OF GUATEMALA 61}

of a comprehensive system of education, which has placed Guatemala on a level, in this respect, with the most advanced countries of Latin America.

The capital of Guatemala during the Spanish Dominion was Antigua (Teepan-Guatemalan), founded by the Conquistador Alvarado. This fine old city, with its multitude of historical treasures, and its early Spanish architecture, was destroyed by the earthquake and deluge of water from the crater of Agua, in I54I. The ruins alone remain to tell the story of the first great capital in this portion of Central America. These Spanish-Colonial remains are of great interest to the archæologist and antiquarian. The crumbling walls of solid masonry, carved and frescoed, speak eloquently of bygone ages. The churches of massive stone, with vaulted roofs, now covered with prolific growth; the subterranean passages leading to the monasteries; the remains of the Viceroy's palace, still showing the Royal Arms of Spain, and the lofty ruins which rise from the ground on every hand, intermixed with the buildings of the modern city, present a curiously fascinating contrast. Some of the magnificent old churches are even now being used as places of worship, though others have been appropriated for less holy purposes-as stables, forges, and playgrounds for the children.

The present capital of the republic is Guatemala City, a growing metropolis, to the description of which future chapters are devoted.

The progress of a newly developed country depends almost entirely upon the means of communication and transportation, and Guatemala, in these respects, has made considerable progress during recent years.

The Central Railway, which was the first iron road constructed in the republic, was opened to traffic in I880. This line, running through the rich coffee 
plantations on the west coast, connects the capital with San José, one of the chief ports on the Pacific. The Northern Railroad, completed in I908, links Guatemala City with Puerto Barrios on the Atlantic coast. These two lines form a through Transcontinental system connecting the Atlantic with the Pacific. In all, Guatemala possesses six railway systems, having a total length of about 300 miles; and the construction of a new line to traverse the country from north to south is now projected.

Owing to the initiative of the present administration, in fostering the construction of the line to the Atlantic coast, Guatemala possesses to-day more railways than any of the other five Central American republics. 


\section{CHAPTER V}

\section{THE SYSTEM OF GOVERNMENT-POLITICAL DIVISION-THE ARMY}

IT is by no means easy to understand a state in which the system of government is representative and democratic, and yet is legitimately, and wisely, controlled by the strong will and intelligence of one man. This sounds paradoxical, and quite impossible; nevertheless, when rightly considered, it is found, by actual demonstration, to be not only possible, but probable in all forms of government, and beneficial in most.

An ambitious man possessed of the brain, the willpower and the knowledge necessary to enable him to subdue all political rivals, and able to understand and utilise the waves of tense political feeling which constantly sweep over every country, is a born leader of men; and, whether he be an hereditary shah, an emperor, a prime minister, or a president, in every state, in every land, he will rule, more or less autocratically, according to the power of his opponents ; although, in some cases, it may be advisable to cloak such government beneath a certain outward deference to public opinion, shown in a great variety of forms, both open and concealed. But, as well in the most republican as in the most despotic country, his will be the plans, his the schemes, and his the policy that must ultimately prevail.

France trembled beneath the great Napoleon, yet she obeyed him, and became, for a brief period, the greatest power on earth; Germany bowed before the "Man of 
blood and iron," who raised her from a collection of petty, wrangling states to a united and powerful nation ; America prospered under Lincoln and Roosevelt, whose names will ever stand among the benefactors of their nation; Great and Greater Britain has been fortunate enough to possess many such in diplomacy and administration, and others expert in the science of war. So it has ever been, from the dawn of history to the present day. A weak ruler means a restless and impoverished nation; a series of weak rulers brings national disaster.

Guatemala, although a small, and in comparison with her great neighbours an unimportant, state, is, nevertheless, now, for the first time, blest with a strong leader. That he has faults is true, but what truly great man is without them in a marked degree? The past tells us that they are unavoidable adjuncts of genius. President Cabrera has already done much for his country, and there is little doubt that the near future will see the successful completion of many schemes of which he is the originator.

In order to gain a clear insight into any nation and its affairs, it is necessary first to understand the ways of government, and the hopes and aspirations of the people. For this reason, it may prove interesting to give here a few of the more important projects that have recently occupied or are now occupying the attention of the Government. Before doing so, however, it should be pointed out that only during the last twenty years has Guatemala possessed even a form of stable government, and much time has been occupied, much commerce and its profits have been lost, and development has been greatly retarded, during the struggles between political factions. The revenue decreased, and financial complications ensued; agriculture was neglected, because of the lack of means of transport; public education was almost non-existent; the army 


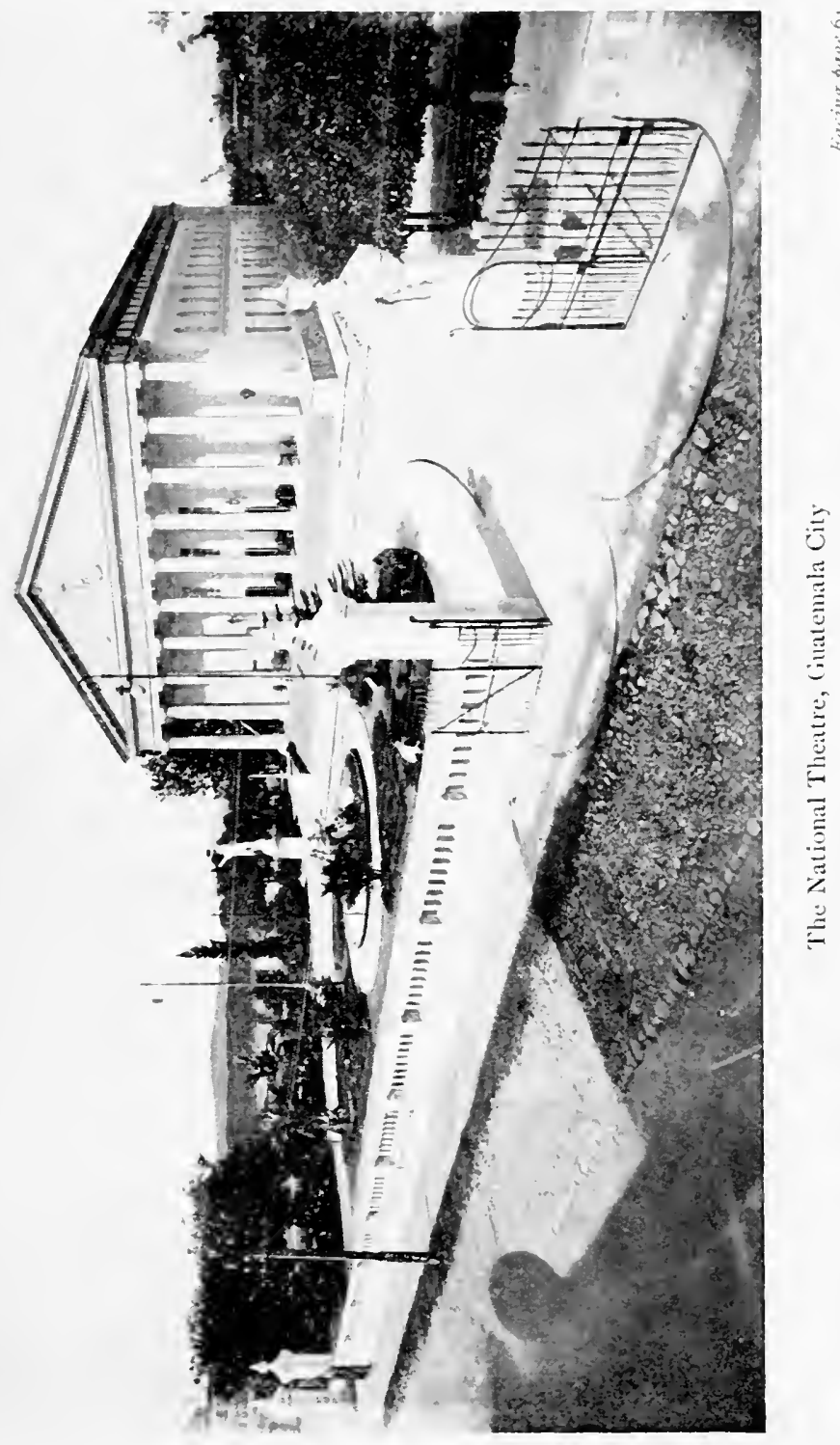





\section{THE SYSTEM OF GOVERNMENT 65}

was quite untrained; the arm of the law was not powerful enough to enforce its judgments ; crime remained unpunished; bribery and corruption were the order, rather than the exception-such was the state of affairs in Guatemala less than a quarter of a century ago. It would be idle to say that all is now well, and that further reform is unnecessary; but it is an indisputable fact that order has succeeded chaos, and that life and property are now as safe as they are in many European countries.

Some of the principal reforms and new institutions placed here in review order may assist the reader to understand what has already been done, what is being attempted, and may enable him better to realise the present political state of the country. Division of the state into political areas ; the completion of the Transcontinental Railway ; the linking-up of the Guatemalan railways with the lines of the Pan-American system from New York and Mexico City; reorganisation of the army, and the addition of an adequate army medical service; reform of the penal and civil codes; promulgation of new mining and immigration laws; establishment of five courts of appeal ; improvements to Guatemala City ; vigorous promotion of industrial, mineralogical, and agricultural exhibitions ; Guatemala City chosen as the meeting-place of the fifth PanAmerican Medical Congress ; establishment of asylums and houses for aged poor; new hospitals, with English and American nurses ; reorganisation of the police and detective forces ; inauguration of the national fêtes of Minerva; the establishment of an extensive system of education, comprising the following:-509 elementary schools for boys, 439 elementary schools for girls, I68 mixed schools, I6 higher standard schools for boys, and an equal number for girls, with normal schools in the eastern, central and western districts of the country ; together with colleges of law, military science, letters, 
medicine, art, pharmacy, commerce, and industry. To these we must add-extension of the systems of public roads, postal service, and telegraphic net (5848 kilometers, 208 offices) ; postal union rates; redemption of the International Loans; the establishment of a system of charity stamps; formation of agricultural colonies; the inauguration of an International Court of Arbitration at Cartago (Costa Rica) and the formation of a Bureau of Central American Republics in Guatemala City.

These are the principal schemes now occupying the attention of the Executive. There are, of course, many others of minor importance, which it is quite unnecessary to mention here. It will, however, be generally conceded, from the above enumeration of the work in hand, that the Government have a programme which will take many years to complete, although some of the reforms and new institutions given in the above list have already been established, and, as later pages will show, most encouraging results have been obtained.

Before giving a few notes on the army, and plunging into a descriptive account of the country and the people, it may prove of use to travellers, who propose visiting the " Land of the Quetzal," to give here, in tabular form, the division of Guatemalan territory into political areas, together with the chief towns and their distances from the capital.

\section{POLITICAL DIVISION}

\begin{tabular}{llcc}
\multicolumn{1}{c}{ Departments } & \multicolumn{1}{c}{ Capitals } & Altitude & $\begin{array}{c}\text { Distance from } \\
\text { Guatemala City }\end{array}$ \\
\hline Guatemala & Guatemala City & 5000 & $\ldots$ \\
Chimaltenango & Chimaltenango & 5360 & 3 I miles \\
Socatepéquez & Antigua & 53 I4 & 23 ," \\
Amatitlan & Amatitlan & 4212 & I 5 , \\
Escuintla & Escuintla & I248 & 4 I , , \\
Santa Rosa & Cuajiniquilapa & 3214 & $\ldots$ \\
Jutiapa & Jutiapa & 2821 & 75 miles \\
Jalapa & Jalapa & 4777 & $65,$,
\end{tabular}




\section{THE SYSTEM OF GOVERNMENT 67}

\begin{tabular}{|c|c|c|c|c|}
\hline Departments & Capitals & Altitude & \multicolumn{2}{|c|}{$\begin{array}{l}\text { Distance from } \\
\text { Guatemala City }\end{array}$} \\
\hline Zacapa & Zacapa & 536 & \multicolumn{2}{|c|}{ I 20 miles } \\
\hline Chiquimula & Chiquimula & I $23 I$ & I I 8 & , \\
\hline Izabal & Livingston & 45 & 209 & , \\
\hline Baja Verapaz & Salamá & $283 I$ & 60 & ", \\
\hline Alta Verapaz & Coban & 4010 & 106 & ", \\
\hline Petén & Flores & 478 & 279 & $"$ \\
\hline \multirow[t]{2}{*}{ Quiché } & Sta Cruz de la & & & $"$ \\
\hline & Quiché & 5492 & 88 & ," \\
\hline Totonicapam & Totonicapam & 7894 & 96 & , \\
\hline Quezaltenango & Quezaltenango & 7351 & 110 & $"$ \\
\hline Retalhuleu & Retalhuleu & 968 & 125 & " \\
\hline Huehuetenango & Huehuetenango & 7052 & 159 & ", \\
\hline San Marcos & San Marcos & 7150 & I 35 & ," \\
\hline Sololá & Sololá & 6974 & 73 & ", \\
\hline Suchilepequez & Mazatenango & 1085 & IO4 & $"$ \\
\hline
\end{tabular}

The reorganised standing army of Guatemala comprises only about 5000 rank and file, with I 50 officers, including the staff, but as conscription is in force, and many of the public schools give elementary military instruction, the Government in time of war would have at their disposal nearly 80,000 men, most of whom would be fairly good marksmen. The largest portion of both the standing army and the levies is composed of Indians and half-breeds, who, while obedient and easily trained, often combine the endurance of the aboriginal with the dash of the Spaniard. These men make fairly good soldiers; but, like the Soudanese and Hausas, they are prone to reckless firing and often become very excited when in action, making instant control by their officers very difficult.*

It would be idle to compare the military forces of the republic with those of the Powers of Europe ; but they are adequate in numbers for the territory they are intended to protect. The training of the Guatemalan army on the German principle is, however, undoubtedly a mistake; as the conditions, both climatic, topographical, and military, under which fighting would be

* There is also a Reserve Force of some 50,000 men. 
carried on in Central America, and in all tropical and but:little developed countries, make the semi-continental methods of Europe-still based, in a large degree, on the teachings of the war of $1870-187 \mathrm{I}$ - the least suitable for producing efficiency in the science of semi-guerrilla warfare, in which the " Arme blanche," the " momentum of the mass," and the " power of concentrated artillery fire," for political, financial, and geographical reasons, are mere phrases that, under the existing conditions, could not possibly be acted upon.

An active military service of one year's duration is obligatory in Guatemala, between the ages of eighteen and twenty. But the rich may purchase immunity; consequently recruiting is confined mainly to the poor. The Government, however, reserves the right to send out their press-gang when urgent necessity arises. Occasionally, not so very many years ago, soldiers would swoop down upon an unsuspecting village, seize all males therein capable of bearing arms, and carry them off to a neighbouring village, where they would be consoled with draughts of "white eye," the native liquor, until even the weeping wives, mothers and sisters at home were forgotten, and oaths and objurgations had changed into roars of " Long live the Republic!" " Long live the President!" 1 During the last revolution, so the story goes, the commandant of an inland town sent down to a village for volunteers. Escorted by a company of soldiers, they came-some bound hand and foot and slung on pack-mules, some tied together, others walking, with their hands roped to the mules' tails. With this consignment the commandant received, from the officer in charge; the following :-_" I send you herewith the volunteers required. If you want any more, send more rope."

The laws are based principally upon ancient Roman
${ }^{1}$ N. D. Winter : "Guatemala."
${ }^{2}$ N. H. Castle: "In Guatemala." 



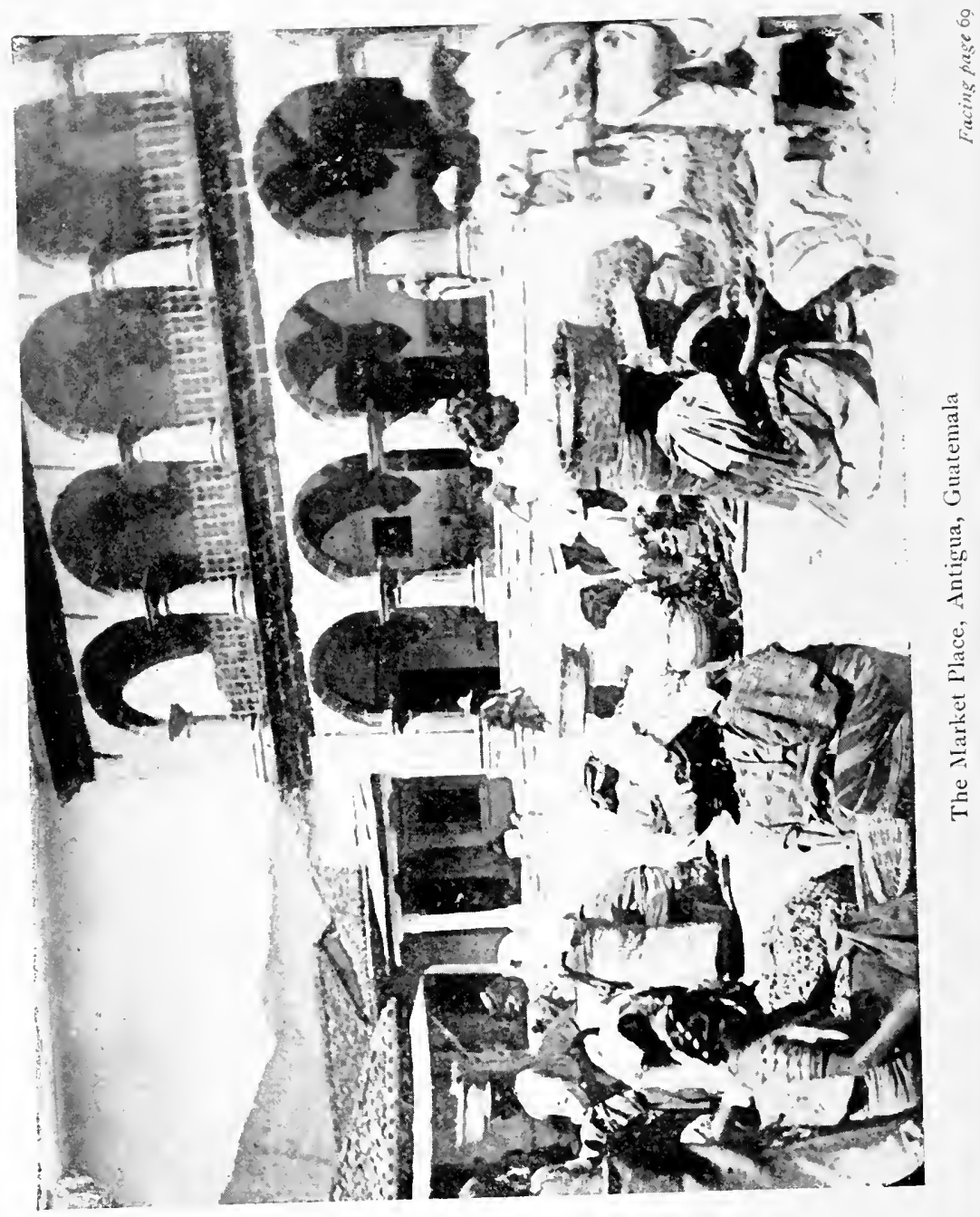




\section{THE SYSTEII OF GOVERNMENT 69}

law, and partly upon Spanish statute. They come under three codes, criminal, civil, and commercial, which are amended by edicts of the Congress, and published in an official gazette. The lowest form of tribunal is the police court, conducted by the Alcaldes, but important cases are tried by the Courts of First Instance, each having jurisdiction over one or more departments, the Court of Appeals, and the Supreme Court, or Court of Cassation, which sits in the capital only.

The procedure of these courts is somewhat lengthy and tedious, as judged by our English standards! All legal documents must be written on stamped paper, a source of considerable income to the Government. Many of the Guatemalan lawyers are men of great ability, who bring to their profession, knowledge, eloquence and probity. 


\section{CHAPTER VI}

\section{THE GUATEMALA OF TO-DAY}

" Just as the Continent has been called the 'Continent of Opportunity,' so the Country, Guatemala, has been called 'The Country of the Future." "-Charles M. Pepper.

THE dominant impression conveyed to any individual, who, by travel or study, has made himself conversant with the republic of Guatemala, must certainly be its great possibilities. The ambitious man of affairs marvels at the diverse opportunities for commercial exploitation, of which, even in these days of keen oversea enterprise, so little use has as yet been made. The traveller on pleasure bent delights in the scenery, in the quaint, old-world customs, and the absence of the tourist crowd; yet he, too, marvels that such a land of virgin beauty should have so long been left untrodden by the army of globe-trotters, and explored only by its scouts.

The colony makers, the planter, the mining engineer, the contractor, and the storekeeper, will all find room, and to spare, for the exercise of their skill and enterprise in the 46,700 square miles of territory composing this Central American state ; for it is a land wherein, with the expenditure of a small capital-as labour is cheapgreat things may be accomplished.

It is a mystery to me to know why so many English farmers are content to waste their lives in our own country when such opportunities await them as are to be found in this favoured land of which I am writing. During how many months can you grow crops at home? 
Here in Guatemala you may plant all the year round ; and your harvest is almost perpetual. Is it hard work that you fear? I would not lure you with false promises ; I acknowledge that the work of the pioneer is hard. But is not all work, that is worth doing, hard ?-even though you do it for its own sake. And here you shall not do it for its own sake. Here Nature rewards faithful work with foison-with full measure pressed down and shaken together. Do you fear the climate? I venture to say that the Guatemalan death-rate is not higher than that of England or America. Do you fear strange lands, strange laws, strange people? If you do, you must just stay at home-and prosper, or fail to prosper, as best you may.

The reader will ask why-if such be the case-has this country been left out, when all the states of South America have been raised on the mighty backs of British and American capital, and are now well on their way towards complete development. To answer this question is difficult ; for the reasons are many. Until recent years, Central America was looked upon as the playground of the adventurer, and, as such, was an extremely risky place in which to live, or to invest capital ; its climate has been the subject of much unintentional libel; its position, between the giants of the north and south, has cast shadows upon its political future ; and the errors of financial administration that, from time to time, have been made by the statesmen of these young countries have caused financiers to pause and consider. These deterrent features, however, where they really existed, are now things of the past, and in Guatemala, at least, the spell, for some years, has been broken, though, unfortunately, not to the proportionate benefit of British commerce ; for the United States and Germany have been first in this new field, and are fast exploiting it. German firms own by far the largest area of coffee plantations ; consequently Germany is a large 
importer of machinery, etc., while United States financiers are interested in the railroad, the harbours, the steamship communication, the banana plantations; and, as recently as IgII, have obtained very wide mining rights from the Guatemalan Government, on most liberal terms.

The result of this competition has been; that England, who once held the first place in the oversea commerce of Guatemala, is now third on the list, with every prospect of falling further behind in the race for commercial supremacy, unless the financiers and merchants of the Empire can be induced to turn their attention seriously to this comparatively new field for exploitation.

Having now given some idea of the history, political position, and possibilities of Guatemala, I will defer until another chapter further details of the commerce and industries, and will endeavour to give a brief topographical and general survey, to enable a clear conception to be obtained of the country itself, before describing the journey across the state, from the Atlantic to the Pacific coast.

Guatemala is the largest, most populous, and by far the most important state in Central America. It has an area of 46,774 square miles, and a population of nearly two millions. It occupies the northern portion of the isthmus which joins the vast territories of North and South America. On its northern frontier lie the Mexican states of Yucatan and Campêche, British Honduras and the Gulf of Honduras; on the west are the Mexican states of Tobasco and Chiapas ; its eastern frontier lies contiguous with the republics of Honduras and San Salvador, and the southern shore is washed by the Pacific Ocean.

The coastline on the Atlantic measures considerably over one hundred miles, and, on the Pacific side, just over two hundred miles. These extensive maritime 


\section{THE GUATEMALA OF TO-DAY}

frontiers, on both oceans, give to Guatemala exceptional geographical and climatic advantages-namely, great facilities for oversea commerce, also the cool sea brcezes that temper the heat of the low coast lands.

The centre of the country is traversed by the cordillera of the Andes, and the Arcaic cordillera, which, with its spurs, forms the southern end of the great range. This mountain system, forming an immense tableland, some 30,000 square miles in extent, is the most densely populated portion of Guatemala ; its prosperity being due to the absence of fever, which is somewhat prevalent on the lowlands of the coast, and to the equability of the climate, which can only be likened to an almost perpetual English summer. On the high plateaus, the climate, indeed, is all that one could desire. The sun heat is tempered by the altitude, and at Guatemala City, the capital of the republic, situated in the centre of a wide plain elevated some 4500 feet above sea-level, the almost unbroken succession of bright, sunny days makes life most enjoyable, and imparts a feeling of freshness and exhilaration to the traveller who has come up from the hot and damp coast-lands. Guatemala City, however, has one natural drawback. Being built on loose soil, it is subject during the dry season to dust-clouds, which are somewhat injurious to those suffering from pulmonary complaints.

Guatemala may be divided climatically into three zones. The narrow stretches of country bordering the oceans are subject to excessive heat, although the climate is not altogether unhealthy; the tablelands, at a height of from 2000 to 5000 feet, possess a more temperate atmosphere, while the higher levels enjoy a cold, though healthy, climate.

The name of winter is given to the rainy season, while the dry season, which lasts from January to May, is known as the summer. In by far the larger portion 
of the country frost is quite unknown, but on the lofty summits of the mountains a white snow-cap is sometimes seen. The hottest months of the year are April, May and August, when the sun, crossing the latitude of the country, blazes directly overhead; but even these months, in the highlands, are by no means unpleasant, as the heat is tempered by the altitude.

The rate of development of a new country depends almost entirely upon its accessibility from the outside world, upon the efficiency of the ocean-carrying services, connecting its ports with those of the great shipping centres, and also largely upon the means of transportation between the interior of the country and the sea-coast. Therefore, before proceeding any further with the description of the country, it is as well to say something of the means of internal and external communication. Guatemala, in these respects, has made rapid strides during the last ten years. The favourable geographical position of the country will more easily be realised when it is pointed out that the Atlantic coast ports are within four days steam of New York, within three of New Orleans, and ten of Liverpool. Those on the Pacific coast are ports of call for regular lines of steamers to and from the Far East, San Francisco, and all the ports on the west coast of South America.

When once the shores of Guatemala are reached, almost every populated portion of the country may be visited by railway. The 440 miles of railroad being laid out systematically, all important points are well served, considering the vast area and sparse population of the country through which the lines run. The most important system is the Transcontinental, which runs from Puerto Barrios on the Altantic, through Guatemala City, to San José on the Pacific. This wonderful railway connects the capital of the republic with the principal ports on both oceans. The variety and beauty 
of the scenery bordering this line merits a full description in a later chapter. The road rises from the blue waters of the Pacific, and passes through the sugar and coffee plantations to the fir-clad cordillera of the Andes, where the air is heavy with the scent of the pine. Thence the line runs down to the Atlantic coast, affording a view of Igo miles of ever-changing scene. The tepid breeze is perfumed with the scent of the northern rose; then, as the train reaches the tropical plains, orange groves take the place of pine forests, and the rich perfume of wild magnolias, and other flowers of the torrid zone, adds to the enchantment of these wide stretches of banana, palm and fern.

The other railways of Guatemala are the Verapaz and Ocos lines in the north of the state; the Great Western, which passes through Retalhuleu, and terminates at Champerico, a relatively large port on the Pacific; and the Urban Railway, which has for its sphere of activity the capital and surrounding districts.

Second only to the means of transportation come the systems for the quick transmission of messages. The postal service of the republic has recently been reorganised on a thoroughly efficient basis, and every year sees an increase in the amount of correspondence handled, and an equal increase in the rapidity with which the mails are sorted, despatched and delivered. The approximate number of post offices established in the country, at the moment of writing, is $28 \mathrm{o}$, and the actual extent of the telegraphic net is 4000 miles. The remarkably cheap rate charged for the transmission of telegrams causes this national system to be much used, and consequently it yields an important annual revenue. The telephonic net is also fairly extensive, and the number of subscribers is steadily on the increase.

The principal seaports of the republic, on the Pacific coast, are San José, Champerico, and Ocos ; and, on 
the Atlantic, or Gulf of Honduras, Puerto Barrios, Santo Tomás and Livingston. ${ }^{1}$ These important shipping centres are the doors through which the principal foreign commerce enters and leaves the country.

The present importance of the oversea trade of Guatemala is nothing compared with its future possibilities. The opening of the Transcontinental Railway, and the increasing interest evinced by European and American financiers and merchants in the exploitation of the rich virgin lands and forests, together with the opening up of several mineral zones, and the stimulus given to immigration by the recently enacted Liberal laws, has already had an effect upon the maritime commerce of the country; and when the great natural wealth of Guatemala, much of which at present lies dormant, is exploited, as doubtless it will be during the next few years, then both the internal and external trade of the country will receive a great impetus.

Having now reviewed the country, its history, its administration, and its commercial status and development, details of finance and commerce must be left for the present, and the exploration commenced of this interesting portion of the once famous SpanishColonial Empire.

${ }^{1}$ Livingston is named after an English barrister to whom the framing of the original Guatemalan Code was entrusted. 


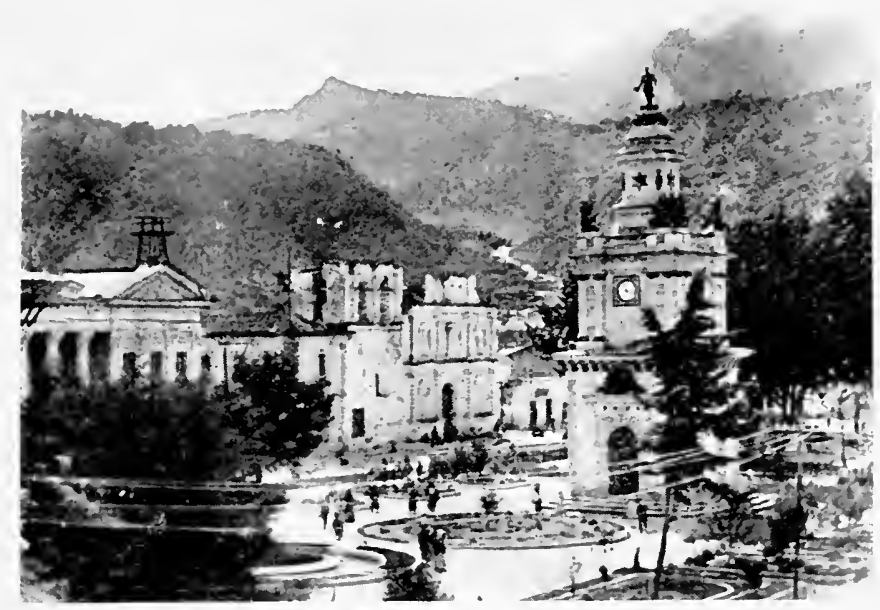

The Plaza, (ruezaltenango, (iuatemala

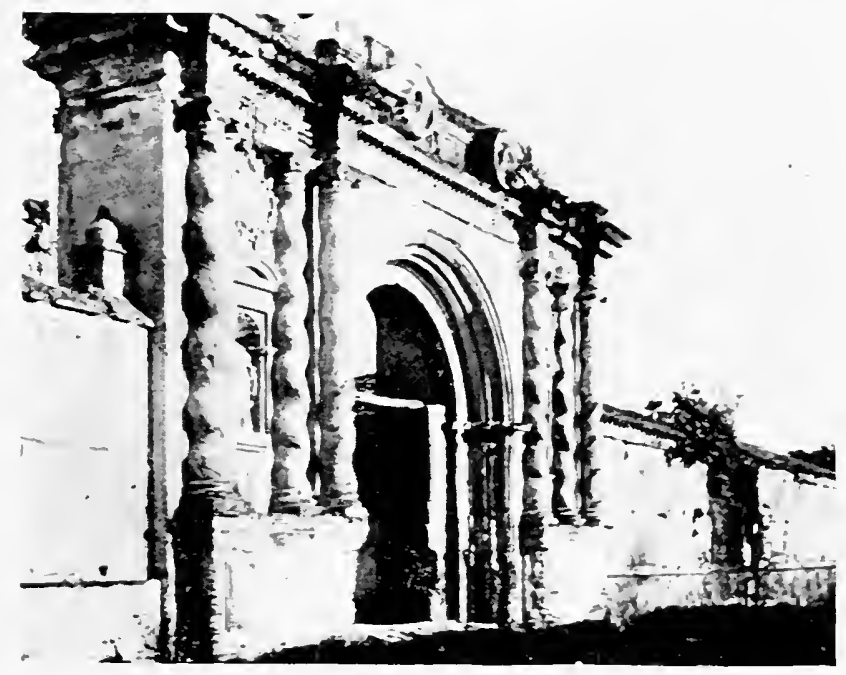

Ruins, Antigua, Guatemala. An old Spanish (iateway, a Relic of the Colonial Days 



\section{CHAPTER VII}

\section{THE ATLANTIC COAST}

ALL around are the weedy waters of the Gulf of Armatique shimmering in the noonday glare. The coast is scarcely discernible through the heat mist; then, as the distance lessens, and the steamer approaches the shore, tall coco-palms and tropical foliage, moist, green, and exuberant, appear on every side. This is the ocean voyager's first glimpse of Guatemala after steaming down the coast from New Orleans, or crossing the Atlantic from Liverpool, Hamburg, or other European ports.

The 150 miles of north-eastern frontier, usually termed the Atlantic coast, is in reality washed by the waters of the Gulf of Armatique, which is an extensive arm of the Bay of Honduras. This broad stretch of water, sufficient in area to accommodate half the fleets of Europe, is almost entirely enclosed by picturesque growth-covered banks, sloping gently upwards to ridges of low hills.

Dazzling white houses peep out from amid the tangled vegetation, and everything looks lifeless and still in the sweltering heat; but this peaceful view of tropical beauty soon vanishes, as the vessel draws closer to the shore, and the town of Livingston hoves in sight.

Getting disembarked at Livingston is comparatively simple, but it must not be supposed that landing at Guatemalan ports is always a particularly pleasant operation. The harbour of Champerico, for example, exists only in imagination, and between the steamer and the land are some two or three miles of ocean swell, 
which has to be crossed in a small lighter hauled by a steam tug. As you near your destination the tug casts off, and when the nose of your boat has bumped a due number of times against the pier-head, you are suddenly switched up some fifty feet into space, and deposited, in a shaken condition, upon Guatemalan territory. Even these watery and aerial flights do not end your troubles, since the Government has developed a bad habit of leasing the landing-places of the country to private individuals or companies, who, consequently, have you more or less at their mercy, which is small. When they have duly levied toll upon you, you are puffed off to a custom-house, whose limited officials cast a keen eye upon your baggage ; and, unless you have introductions to persons high in power, will teach you at once that Guatemala is a protected country. The voice of the Free Trader is not heard in the land.

But let us return to Livingston. This important shipping centre is situated at the mouth of the Rio Dulce, at the extremity of the Gulf. Previous to the building of the Transcontinental Railway, which connects the neighbouring town of Puerto Barrios with the capital and the Pacific coast, Livingston was the most frequented port on the Atlantic side. Now, however, the newly planned modern city, Puerto Barrios, at the terminus of the railway, has caused many merchants and shipping agents to forsake the old for the new.

Livingston can boast of few fine buildings ; nevertheless, it certainly has its attractions for the traveller. A shallow bar prevents steamers, even of moderate draught, from approaching the wharf, or entering the river, although the Rio Dulce is one of the finest rivers in Central America, and is navigable for many miles. Steam tenders are used for disembarking passengers and goods, which makes landing at times very difficult. Livingston is a typical, small, Central American town, consisting of the native portion, formed of one-storey 


\section{'THE ATLAN'IIC COAS'T}

whitewashed buildings; the plaza, which faces the quay, and is surrounded by offices with projecting roofs to shield the windows from the almost perpendicular rays of the sun; and the one imposing building of the place-the custom-house. At the back of the town, on raised ground, are situated the more pretentious buildings and bungalows, in which the wealthy portion of the population resides.

The surroundings of Livingston are, however, more attractive to the traveller; for here one may penetrate into the depths of vast forests, or visit one of the many banana estates. The native population are Caribs, who, although of a peaceful and contented disposition, are somewhat lazy. The tall, upright forms of these women, carrying heavy burdens on their heads, and the passing of mules laden with fruit and other merchandise, form the usual street scenes; while, lying off the town, on the blue waters of the Gulf, numerous large steamers may nearly always be observed. The conveyance of merchandise between the ships and the shore, in large lighters, forms a very important and lucrative industry.

Not satisfied with the rapidly growing port of Livingston, the Government commenced the construction of what, in a few years' time, will doubtless be one of the most modern cities on the east coast of Central America. Puerto Barrios was the name given to this new shipping centre, which is situated not many miles from Livingston, on the opposite side of the Gulf, and within a few miles of St Tomás, another small coast town.

Puerto Barrios, the Atlantic terminus of the Transcontinental Railway, will be extended and improved each year. The choice of a suitable site for the construction of this important new seaport required much patient deliberation. In the first instance, it was necessary to choose a position where the water frontage was unprotected by a shoal or bar, and where the depth of 
water alongside the quays would never be less than that required by large steamships; secondly, the surrounding country should be open, and free from serious obstructions which would interfere with the plans adopted for the erection of the city. A large bay, situated some three miles from St Tomás, offered all the necessary qualifications and others besides, the only drawback being the somewhat low ground. Eventually, after the whole Atlantic coast had been thoroughly explored, this was the site chosen, and, to-day, a growing seaport and Trans-American Railway terminus occupies the grass and palm-tree covered plain where, in bygone ages, the Caribs landed and established a village, after being driven from their homes on the islands of the Caribbean Sea. The villages in this district, with their huts made of palm and bamboo, resemble those of Africa. Between the dwellings run narrow paths overgrown with grass and weeds, and cumbered with thorns and branches that catch and cling to one's clothing. Huts are constructed merely of bamboo poles set in the ground at the corners, the walls being constructed of horizontal rods or poles, sometimes filled in witl mortar or stones. The steep roof is covered with a thatch of palm leaves or banana stalks.

About Puerto Barrios little can be said, for it is a city in the making; and any details which might now be given would in a few months become out of date, and in a year or two positively libellous.

The Atlantic coast of Guatemala is famous the world over for its production of choice tropical fruits, especially bananas, which are exported to the United States in immense quantities. The coffee production is also very large, but at present not equal to the amount grown on the Pacific coast. The dense forests on the Atlantic slope abound with valuable woods and other sylvan products. Mahogany, rubber-trees, ceiba and mangroves, besides other varieties, rear their lofty 



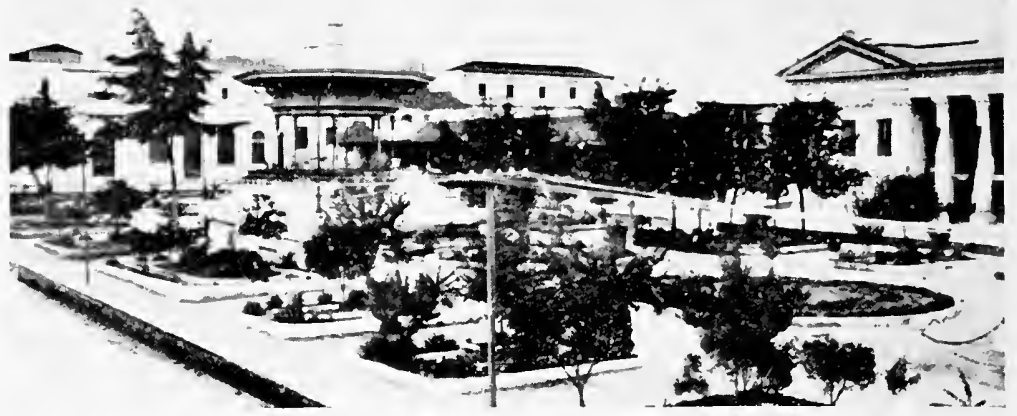

I'laza de Centro-America, (Juezaltenango, Guatemala

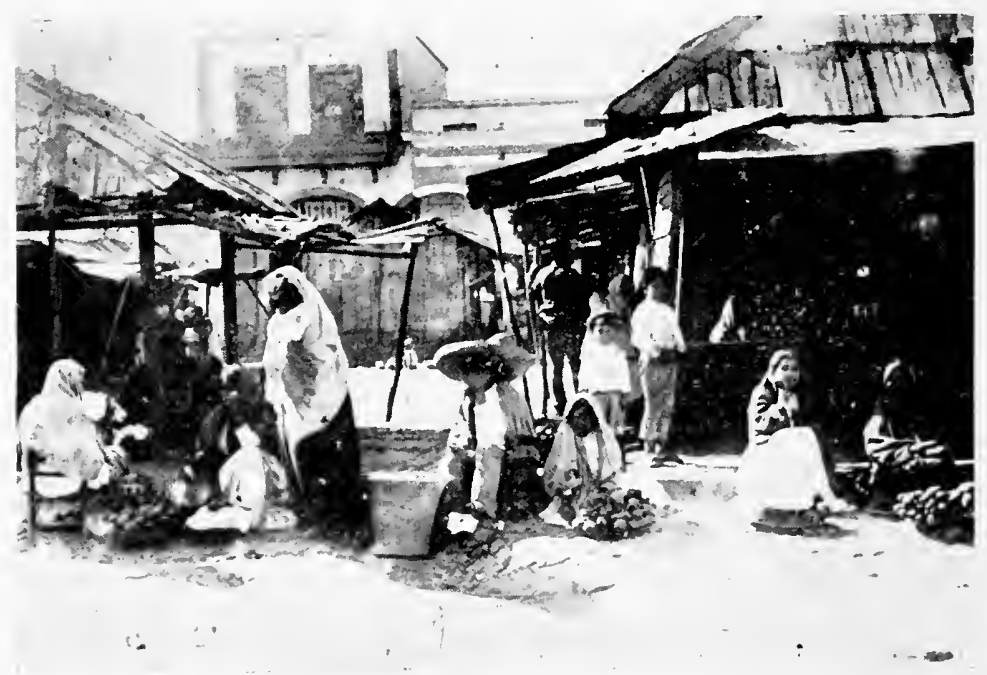

1 Street Scene in (vuezaltenango, Guatemalia 


\section{THE ATLAN'TIC COAS'T}

heads above the tangled mass of luxuriant foliage which completely covers the rich brown soil in the fertile valleys. Growing wild in these jungles, are cocoa, rubber, sarsaparilla, vanilla, and many other products of medicinal or of commercial utility.

In the almost dark recesses of the forest glades the atmosphere is hot and damp, and one breathes the peculiar, heavy odour of the tropical jungle, so familiar to travellers in Equatoria. The rich green foliage, and the lighter-hued fronds of the feathery palm form an Arcadian background for the many bright flowers which climb the tree trunks, or peep from beneath the moist and exuberant vegetation. Orchids, convolvuluses, and a hundred other species of flora, intermingle with the many kinds of fern and tropical growth.

Perhaps the most notable inhabitants of this leafy Arcadia are the birds, whose brilliant plumage and plaintive song is the one enlivening note that breaks the silence of these woodland glades. Among the many varieties in this natural aviary, the one deserving special note is the quetzal, the sacred bird of Guatemala, chosen, since it cannot survive captivity, as the national emblem of liberty. The bright colours of the quetzal form a striking contrast to the dark green and brown of the boughs upon which it sits for hours in solemn silence. Its body, jet-black and pale grey, the wings of a brilliant green, and the breast of soft, fluffy feathers coloured the brightest red, and the lovely tail feathers, of hues varying from dark green to indigo, and of a length that often reaches three feet, make it one of the most beautiful birds of the American continent. In ancient days, only the royal family might adorn themselves with these splendid plumes. They grow upon the male bird only; consequently the female bird is able to live a life of comparative immunity from the Indian hunters, who bring the skins from the forests 
for sale in the towns. This fact probably accounts in part for the perpetuation of the species. The quetzal perches itself on the topmost boughs of the most lofty trees, in the thickest and least penctrable portions of the forests, and will remain in one position for hours without uttering the slightest sound. It is one of the few specimens which it is almost impossible to tame, and, for this reason, as well as for its beauty, Guatemalans regard the killing of this bright-coloured, sober little fighter almost as a sacrilege, and, in their natural admiration, have adopted it as the emblem of the republic.

A steamboat trip from the port of Livingston, up the Rio Dulce, affords, perhaps, one of the best ways of visiting the interior towns of the Atlantic slopes, giving, at the same time, ample opportunities for staying at some of the largest fruit estancias which border the river. At certain periods of the year the high banks of the Rio Dulce present one of the most beautiful sights to be seen anywhere. From the boughs of the most lofty trees a fine network of green fibre hangs like a gauze veil over the vivid colours of the flower-covered banks.

Orange groves and banana plantations stretch away for miles on either side. So important has the fruitgrowing industry become, that several lines of steamships are almost entirely engaged in transporting the fruit, rubber, and coffee grown on the Atlantic coast of Guatemala to the great markets of North America.

Several small villages, principally inhabited by natives, are situated along the banks of the river, but the only town of any importance whatsoever is San Felipe, which stands at the entrance to Lake Izabal. A stone fort of Spanish origin guards the narrow waterway leading to the lake, and with the custom-house, and one or two other buildings, form the only objects of special interest in the place. 


\section{THE A'TLANTIC COAST}

As the steamer crosses the narrows and enters Lake Izabal, a magnificent view unfolds itself. Far away to the south the lofty peaks of the Sierra de las Minas form a rugged horizon against the deep blue of the sky; in the foreground plantations of oranges, limes, guavas, and bananas, with here and there the dazzling white houses of estate-owners, facing the clear waters of the lake, and everything, even the vegetation, looking hot and sleepy in the noonday glare-for it is a time when Nature seems to rest a while in the tropicsmakes a picturesque landscape, the charm of which lies not only in the brilliant lights and shades, but in the gentle, flower-scented breeze, the ripple of the water against the steamers' bows, and the total absence of all excitement and noise, which, to the traveller accustomed to the buzz and hum of great cities, brings a sense of unwonted rest in this veritable Garden of Eden.

In the moist, sunny climate of Lake Izabal, Nature is fecund and prodigal of plant and animal life. Well she may be, since no rival ever comes to challenge perpetual summer's supremacy. Her pageant of blue and green never passes through autumn's gold and brown to winter's silver and grey. Amidst an untold variety of forest trees and ferns and plants hum myriads of mosquitoes and other insects; here, too, flit dragon-flies in zigzag courses; gaudy butterflies, of every hue and shape of wing, balance upon trembling flowers and ferns; winged life, creeping life, is above you and below. Humming-birds, like midsummer fairies, on sportive errands, dart from pool to pool, poise over the flowers, and among the boughs. Each leaf and blade, in Lowell's words, is "some happy creature's palace."

The town of Izabal, in the time of the Spanish dominion, the most important commercial centre on the Atlantic coast, is now but a quaint collection of houses, 
with few attractions, except the beauty of the surrounding district. The rapid progress in the cities of Central Guatemala has robbed this portion of the state of much of its former activity, and the advantages offered by the railway lines running through other portions of the country have caused many rich planters to quit their holdings, and take others in districts where the transport facilities are greater.

It must not, however, be deduced from these remarks that the east and north of the country are destitute of population and industry; on the contrary, the gentle, fertile slopes from the cordillera to the Atlantic are fairly well covered with rich plantations, and there are several small towns, such as Babasco, Zacapa, San Pablo, Cahabon, Panzos, Salama, and others; but the great commercial activity of the country is carried on in the cities of the highlands and the Pacific coast, although a large quantity of fruit annually leaves the country through the ports of Livingston, Puerto Barrios and St Tomás - the harbour of the latter place being one of the safest and largest in Central America.

When leaving the Atlantic coast by the Northern Railway (that branch of the Transcontinental system which connects the capital with Puerto Barrios) the traveller will experience but little feeling of regret, for although the virgin forests, jungles of palms, orchards of limes, groves of oranges, and plantations of bananas, combined with the ever-changing beauty of tropical scenery, where the maximum luxuriance of vegetation is reached, certainly offer many attractions, the visitor will naturally be eager to see Guatemala proper"the nation on the tableland"-and to feel the cool breezes of the mountains which quickly dispel the malaria of the coast. He will promise himself, too, a visit to the wonderful ruins of Antigua, the capital in the early colonial days, where even now one can live 


\section{THE ATLANTIC COAST}

again, in imagination, the stirring lives of the brave pioneers, who first conquered the land for the Crown of Spain; and, with such a prospect in view, he will hasten to quit the torrid regions of the coast, and commence the journey from ocean to ocean. 


\section{CHAPTER VIII}

\section{FROM ATLANTIC TO PACIFIC}

THE Interoceanic Railway, which completely crosses the republic, is divided into two distinct sections. That portion of the line running from Puerto Barrios to Guatemala City is known as the Northern Railroad ; and the line connecting the capital with the Pacific port of San José, as the Central. The distance from ocean to ocean, by these two railways, is 269 miles.

The many difficulties encountered and overcome by the constructors of the Northern Railway it would be impossible to describe here; sufficient to say that, in a few hours from the time of leaving Guatemala City, the train has traversed the platean, crossed the heights of the Andean Cordillera, and descended into the tropical forests of the coast - the result of a marvellous feat of engineering skill and administrative ability.

It is necessary, before commencing the journey over these parallel lines of metal, to realise the commercial importance of this road, both to the country across which it runs, as well as to the other nations of the same continent, and even, in a minor degree, to those of Europe. It places the Pacific coast within eleven days' journey of London, Liverpool, and Havre, and thus considerably shortens the distance between Europe and the Far East, and also the rapidly growing Pacific ports of South America. It opens up the rich pastoral, agricultural, and mineral lands of Central America, and places Guatemala City within five days' journey of New York, within eleven of London, twelve of Hamburg, eleven of Havre, and four of New Orleans. The 
advantages to Guatemala, both political and commercial, of this Transcontinental Railway, cannot be overestimated, and the foregoing should serve to demonstrate its importance to the commercial world.

The Northern Railway, by far the longest and most important section of this system, was commenced during the presidency of J. Rufino Barrios; but, as has been the case with many another sorely needed undertaking, it was left to the present administration to give the impetus necessary for its successful completion. The line was opened on Igth January I908, by President Cabrera, and the representatives of many nations, who had been invited to join in the ceremony of the inauguration of the first Central American Transcontinental Railway.

The Central Railroad, connecting the capital with the Pacific coast, was opened in the year I884, and nearly every year since its completion there has been a considerable increase in the number of passengers and the amount of merchandise carried. The success of this; the first railroad constructed in Guatemala, prompted the extension of this line from Santa Maria, through the rich coffee-producing zones of the western coast to Mazatenango, placing the latter important centre in direct communication with the Mexican frontier.

The journey from Puerto Barrios to Guatemala City, which occupies about twelve hours, takes the traveller through three different regions-the tropical forestcovered lowlands of the coast, the fir-clad mountains of the low cordillera, on to the lofty plateau of Central Guatemala.

During the first few hours of the journey, after leaving Puerto Barrios, the train passes through dense forests of palms, orange groves, and mangrove-trees; in the far distance, blue mountains, with summits clothed in cloud, complete the panorama.

The warm breeze, coming through the open windows of the carriages, is heavily scented with the odour of the 
forest. In places the line is so hemmed in by the luxuriant and rapid growth of tropical vegetation that the boughs of trees, or the long, feathery arms of the giant grass, sweep the sides of the passing coaches.

Within a few miles of the coast, the primeval forest in many places has been cut down, and, for several leagues, the way leads through banana estates, giving the surrounding country, on both sides, the appearance of a veritable jungle of these fruit-laden trees.

As the train proceeds, the incline increases, and the country assumes a changed appearance. Orchards of oranges, lemons, and limes take the place of the banana jungles, and the atmosphere becomes perceptibly cooler.

Many are the small, neat little stations called at ; but it would be both uninteresting and unnecessary to describe them here in detail. Only by the scenery and the language can the traveller tell, with any degree of certainty, through what country he is travelling. The smooth running of the coaches, the rock-ballasted road, and the oil-fuel locomotives, together with the small but neatly built stations, give impressions similar to those conveyed by a journey through Jamaica, or any other tropical country.

After some eighty miles have been traversed, the scenery becomes grander, for, by a gradual ascent, the train has mounted to the slopes of the Andean range. The fir and pine clad hills, the rock-strewn ground of the mountain-sides, and the fertile valleys, where corn is largely grown, and cattle are reared, take the place of the luxuriant, moist, tropical forests of the lowland.

By this time the air has become quite cool, and, as the train climbs over the heights, the views obtained of this mountainous region of the republic are beautiful in the extreme. At one moment the train is suspended by a trellis-work of steel over a deep chasm filled with fine trees, an instant later it is skirting the base of a mountain, with walls of rock upon every side. 


\section{FROM ATLANTIC TO PACIFIC}

When the line is clear of broken ground, and the sunlit tableland of Central Guatemala, with its low, greencovered hills and cultivated acres, stretches away to the dim, hazy outline of far-distant mountains, another entirely different land seems to have been reached. At certain points the cool breeze is laden with the delicious perfume of the rose, violet, or carnation, and the byway stations seem suddenly to have awakened from their sleep, and assumed a busy aspect.

The countryside is more populated, and the towns through which the line passes are far larger and busier-the stopping-places on the lowlands of the coast are, in several instances, really nothing more than country halts, surrounded by fincas, or fruit farms.

After about eleven and a half hours' travelling, the wide plain, upon which stands Guatemala City, is reached, and the first section of the Interoceanic Railway has been traversed.

The chief stations along this 195 miles of line are : Puerto Barrios, Tenedores, Las Animas, Los Andes, Los Amates, Santa Inéz, Iguana, Gualan, Los Robles, San Pablo, Zacapa (one of the most important towns, near which the line passes close to the ruins of Quirigua), La Reforma, Cabañas Jalapa, Barranquillo, Estrada Cabrera, Flamenco, El Rodeo, El Fiscal, La Chorrera, Menocal, and Guatemala City.

After crossing the capital of the republic, which will be described in subsequent chapters, the journey from coast to coast is continued by the Central Railroad. This line, which has a total length of seventy-four miles from the capital to the seaport of San José, runs down the western slopes of the Andean Cordillera to the Pacific. The line of heights, dividing the whole country into two zones, follows the contour of the Pacific coast at a distance therefrom of about sixty-five miles, forming a watershed. 
So marked is this dividing-line-state several American writers of wide geographical knowledge - that the ridge of the roof of the parish church of Chimaltenango scems to divide the rainfall so equally as to cause one half to flow to the Atlantic and the other half to the Pacific Ocean.

For the first few miles after leaving Guatemala City the line cuts through a very mountainous region, passing within view of several volcanoes. Lake Amatitlan is then reached, and the train for some time skirts the shore, affording a magnificent view of this beautiful sheet of blue water, surrounded by exuberant growths. The curiously shaped canoes, moving to and fro over the placid waters, and the white bungalows of the estateowners, afford a picturesque scene, quite unlike that on Lake Izabal on the opposite side of the republic.

The first halt after Amatitlan is Palin, the nursery and market-garden of the capital. About this place little can be said, for, in common with many small towns of Central America, there is little of interest to be seen beyond the natural beauty of the surrounding landscape.

After crossing the Rio Michatoga the descent to the Pacific coast commences, and the vegetation again becomes tropical. Giant prickly cactus, wild magnolia, dwarf-palms, and royal palms mingle together in profusion. Sugar and coffee fincas spread over the country; some of areas of many square miles, and, at certain places, the train runs for several minutes through forests of cane, and passes hundreds of acres covered with the olive-green of the coffec bush.

Esquintla, a picturesque town and busy agricultural centre, is the last important stopping-place before the coast. After about twenty miles of beautiful country, clothed in the gay colours of the tropics, have been traversed, the low coast and the waters of the Pacific, shrouded often in a hot, blue haze, appear in view. 


\section{FROM ATLANTIC TO PACIFIC 91}

The white houses, mostly one or two storeys high, the narrow streets and the long, iron pier stretching into the sea beyond the surf, are the chicf features of the port of San José, which is the closing view in the scenic panorama of the journey across the continent. 


\section{CHAPTER IX \\ GUATEMALA CITY}

THe finest and most modern city in Central America is, undoubtedly, the capital of the republic of Guatemala. Situated on a plain elevated some 5000 feet above sea-level, it enjoys one of the most equable climates in the world. Practically the only difference noticeable between one season and another is the cool breezes of the evening, in the wet season, and the amount of rainfall, which is more copious than during the months from January to May.

If the traveller obtains his first view of Guatemala City from the surrounding country, then the impression created by its glittering white houses, almost buried in green foliage, will remain as a pleasant recollection for the remainder of his life ; but, on the contrary, should he be suddenly placed in the poorer quarter of the city, with its monotonous succession of ill-paved streets laid out on the Spanish-American principle, running at right angles to each other, with the low, two-storey white buildings stretching away on both sides of every street, with nothing but an occasional church to add architectural beauty to the scene, his entrée into the capital may not leave so favourable an impression. What poor city is there, in this now busy world, to which the same conditions do not apply: the Latin quarter of Paris, the Queen of European cities, can scarcely be called picturesque; no more fair, if first seen from the East End, is London, the King of commercial centres. Yet if you approach Paris from St Cloud, or overlook the vast 
arca of London from the towers of the Crystal Palace; the change of scenc is as great as that between the waters of the ocean in calm and storm. Mount to the summit of the fine cathedral, and survey Guatemala City, from the Avenida Reforma to the distant volcanoes, and the vicws of the white, sunlit town cannot fail to inspire enthusiasm in all lovers of the picturesque.

Or mount at evening one of the hills without the city. From the Cerro del Carmen, for cxample, the large white churches of the city, and its walled gardens full of trees and flowers, offer, at any time, but especially at sunset, a scene of surpassing beauty. From the distant sea come floating clouds that wreathe themselves around Fuego and Agua, and veil the amphitheatre in purple shrouds of hills, the summits aglow with sunset glory. From the bosom of every valley the mists come creeping upward around the mountain slopes. The short twilight clothes herself in a garment of deepest blue, and one by one the brilliant stars of tropical night look down upon the fairy city.

Before entering into a detailed account of the many fine avenues, parks, and buildings, it is as well to give a few indisputable facts, to enable the reader to judge for himself of the size and development of what must, in future, become one of the first cities of the New World.

The lowest estimate places the population of the capital of the republic at 120,000 , which, however, does not give a fair conception of its actual size. All the surrounding country is under cultivation; and in many parts there are a large number of small holdings and market-gardens. The inhabitants of these suburbs, coming to town every day to dispose of their agric ultural produce, and the ever-increasing number of people on their way from ocean to ocean, who break their journey at the commercial metropolis of the country, give Guatemala City a fairly large floating population, which greatly increases the number of people actually in the 
city during the day. Should any verification of this fact be needed, the traveller, to convince himself, has only to visit either the central, or one of the other markets, where the principal portion of the trade is carried on.

During recent years the whole city has been lit by clectricity, and all the important thoroughfares are illuminated at night by arc-lights. The National Theatre, the Executive Palace, the artillery barracks, the cathedral, the hospitals, and all other public buildings of importance are likewise illuminated. Many cities of Europe and the United States have no better lighting systems ; and in this respect, as in almost all others, the capital of Guatemala is far in advance of all its Central American rivals. Street tramways cross and recross the city in all directions, and connect many of the suburbs with the Central and Northern Railway stations, and with the Plaza de Armas, which is surrounded by the chief public buildings, notably the Presidential Palace, the Executive Palace, the cathedral and palace of the Catholic bishop.

Guatemala City, it must be remembered, is intersected by many parks and open spaces, and is laid out upon an extensive plan covering a wide area, to enable the cool breezes to temper the heat, which, owing partly, no doubt, to this method of city construction, and primarily to the elevated plateau upon which the city stands, is never excessive, nor unbearable, as in most intertropical countries.

Its approximate extent is seven miles from north to south, and nineteen miles in circumference.

The sanitary and medical arrangements of the city are amply sufficient. The drainage is good, and the water-supply pure. A Medical Board of Public Health supervises all branches of the sanitary system, and the medical establishments are numerous, there being nearly a dozen hospitals, among which must be mentioned the 
General Hospital, the Military, the Estrada Cabrera, the Convalescent Home, and the Hospital for Epidemic Diseases. There is also a Maternity Home, which owes its human existence entirely to the support of the mother of President Cabrera, by whose efforts the necessary funds for the erection of this fine building were subscribed. A dirt-destructor, situated at a considerable distance from the populous centre, also tends to diminish disease among the poorer classes.

After the terrible earthquake, which destroyed the ancient capital, Antigua, at the base of the volcanoes "Fire" and "Water," and in the most mountainous part of the country, the site where now stands Guatemala City was chosen, as the most salubrious and best position for the new capital of the republic.

Many eminent patriots questioned the wisdom of establishing a new city in what was then such an inaccessible position, and favoured a sea-coast site. The objection to this was the somewhat unhealthy climate of the coast, compared with that of the tableland, and, fortunately for the prosperity of Guatemala, it was wisely decided to construct the capital on the most healthy spot in the whole country-that upon which it now stands.

Although this city, for many ycars previous to the advent of the iron road, remained almost totally isolated owing to its distance from the sea-coast, and, consequently, developed extremely slowly, when compared with the advance made by some of its South and Central American rivals, its progress, now that it is in direct railway communication with both oceans, should be rapid; and through the foresight and self-sacrifice of the early administrators of the country, its future development, unlike that of many other cities of Latin America, will not for ever be retarded by the great drawback of a bad climate.

The residence of his Excellency the British Minister 
for Central America, in Guatemala City, is a proof of the town's importance, and of its healthful character in this important respect.

The construction of a new branch of the Northern Railway, from the city of Zacapa to the Salvadorean frontier, has been commenced. This new line will place the capital in communication by rail with the neighbouring republic of San Salvador.

Not less important than the construction of the Transcontinental Railway is the projected linking-up of the Guatemalan lines with the Pan-American Railway; which has already reached the frontier of the republic.

When this useful junction has been effected, which should be during the next few months, it will be possible to travel by railway from Guatemala City via Mexico City to New York, or even to Canada.

Entering the city from the south by the road which leads into La Reforma, the beautifully laid-out and best promenade in the capital, the most noticeable buildings are the Technical Institute, the artillery barracks, in front of which is the magnificent statue of Señor Granados, and the solid, though old-fashioned, Fort St José-now a convict establishment.

The Paseo de la Reforma is one of the modern improvements to the city. It is a broad, well-paved promenade, lit by arc-lamps, and artistically laid out with grass; surrounded by shrubs and foliage of all descriptions, and ornamented by beautifully carved stone drinking fountains, with fine cupola tops and pinnacles, situated at the extremities of this level boulevard. Among the many handsome buildings facing the Paseo de la Reforma is the palace, a handsome and graceful building, beautifully decorated, with an imposing entrance, and surrounded by Corinthian columns. This palace, the National Museum, is approached on each side by broad stone steps and flanked 


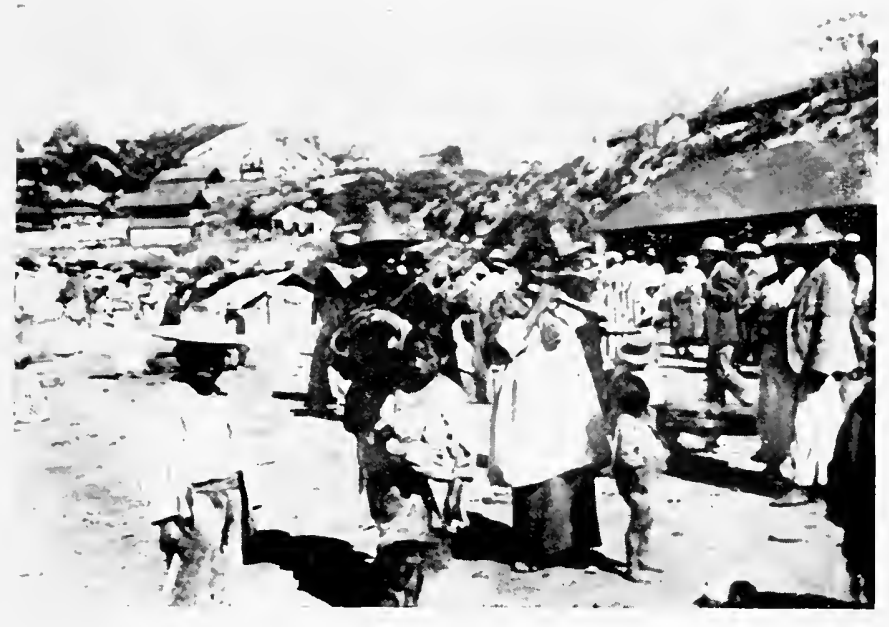

Helvetia, Ciuatemala

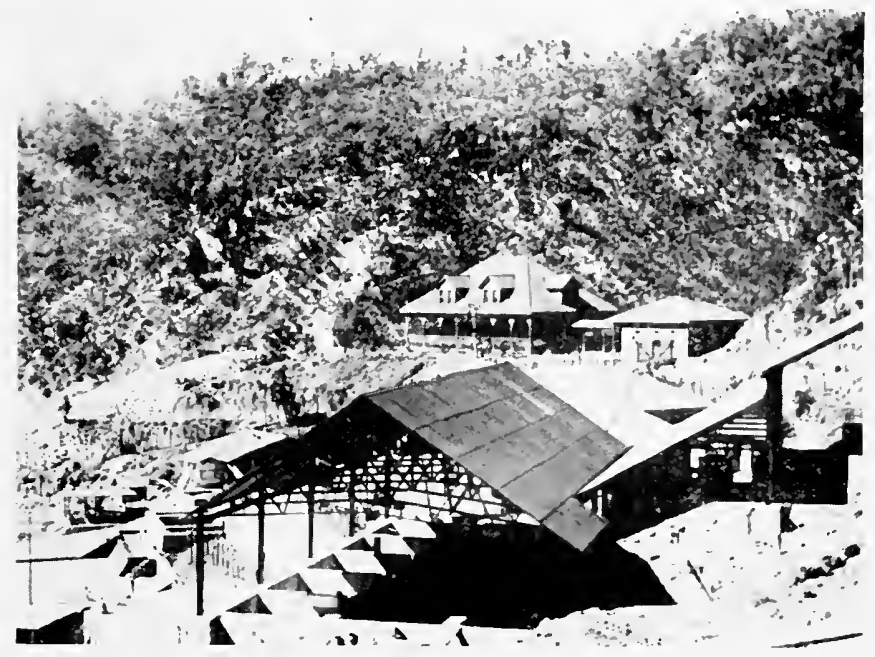

A Cisfee Estate, Jelvetia, Ciuatemala 

by well-carved statues. Near by is the bandstand and the park of La Reforma, in which are several fine statues, also the Estrada Cabrera Park, one of the most recent and prettiest " breathers" in the whole city.

Standing at the end of the Reforma is the asylum for the poor, and the Maternity Home-a fine building, promoted by the mother of the president on behalf of an object worthy of the support of a humane people.

The Avenue of Minerva is another good promenade, commencing in one of the parks, and extending to the entrance of the Hippodrome. The fine villas along this avenue are the residences of the élite of the capital. Almost facing this, the most popular promenade in the city, is the Temple of Minerva, an imposing white structure of colossal dimensions, open to the four winds of heaven, like the buildings of ancient Rome, and raised on a stone daïs, with ornamented roof, supported by massive Corinthian columns. It is capable of accommodating many hundreds of people.

This building, about which more will be said in a later chapter, was constructed by direction of the present administrative for the annual celebration of the scholastic Fêtes of Minerva. It forms one of the principal "sights" of the city.

The Avenida del Hippodromo is another modern thoroughfare, lined on both sides by trees, and flanked by substantial detached villas.

This road leads to the Hippodrome, or racecourse, which is well worth a visit, especially if a meeting or show is in progress. Here, under the cool shade of the grand stand, on these occasions, one may meet the best of Guatemalan society. Even should there be nothing unusual taking place, the traveller is well repaid for the visit by the finely modelled map, in relief, of the republic, showing at a glance the peculiar topography of the country.

The handsome buildings of the city are many. 
With out describing each, it will suffice to mention here a few of the most important of those devoted to public business.

Undoubtedly one of the most imposing structures is the cathedral, with its broad and lofty cntrance, supported by columns, and flanked by towers, the pinnacles and crosses of which rise high above any other building in the whole city.

Another interesting, though by no means imposing, church is that situated on the Cerro del Carmen. It is surrounded by a high and massive wall, which gives it the appearance of an ancient fortress-no doubt a very necessary defence when the church was first constructed in the early Spanish colonial days. The outer entrance is through an opening in the wall, which can be closed by a massive door. This half church and half fortress is, however, only poorly decorated, and is now but little frequented.

Guatemala City possesses a handsome and commodious theatre, facing a broad plaza planted with prettily laid-out trees and flower-beds. The entrance is supported by ten massive stone columns, which, with the well-carved classical pediment, gives the whole building an appearance similar to that of the Madeleine in Paris. During the season a considerable Government subsidy enables the best Spanish theatrical companies to be seen on the boards, and the management does credit to the capital. As a visit to the National Playhouse affords ample scope for studying the tastes of the inhabitants of the chief city of the republic, and enables one to see and understand the impressionable character of the Spaniard, tempered and mixed with the business instinct of the American, an account of a visit to this theatre will be given in the chapter devoted to life in the capital.

Among the other interesting buildings, the following are worthy of special mention:-the Palace of the 
Legislative Assembly, the Mint, the Ministry of Public Works, the custom-house, the Inland Revenue Office, the Post and Telegraphic Offices, the Colleges of Law and Medicine, the markets, the school buildings, and the stations of the Central and Northern Railways.

The principal hotels most suitable for English people are the Gran Hotel, the United States, the Victoria, and the Europe: all these supply the special wants and tastes of travellers from North America or the British Isles.

Several good journalistic productions are published in the capital, and circulate throughout the country. $E l$ Diario de Centro America, La Mañana, El Heraldo, La Republica, and The Guatemalan Post-a weekly paper in the English language-may be mentioned as being thoroughly readable journals, containing all the political and commercial news.

Those who are accustomed to the artistic and brilliantly written newspapers of England and America would doubtless consider these productions somewhat grandiloquent in style, and perhaps a little too trenchant in their political articles ; but, before passing judgment, it must be remembered that the people who live in this land of sunshine possess the vivid imagination and passionate disposition of their forefathers of old Spain, and to them the cool, dispassionate style of the AngloSaxon is like our climate-damping to the spirits.

The public roads in and around the city are mostly fairly good. On many of them it is possible to motor in comfort, and not a few of these vehicles are now to be seen in the capital.

The important highways of the surrounding country are well kept, and in the city, besides a moderately good tramway service, there are a considerable number of horses and carriages for hire. A regular coach service operates between Guatemala City, Quezaltenango, and La Antigua, the old capital, and there is a scheme under 
consideration for the establishment of funicular railways, in these regions which are the most mountainous in the republic.

The rapid growth of Guatemala City, and its possibilities in the near future ; the extraordinary development, during quite recent years, of the agricultural industry of the plateau, and the steadily growing requirements of the population, have enormously increased the country's needs, among the most pressing of which is a stable currency. The present paper circulation is in existence through no fault of the Administrative, either past or present; but is a necessity forced upon the people by the troublous times through which this young country, like all others, has had to pass during the early days of her existence. The adoption of a silver standard, to be followed by a gold standard, is now being seriously considered, and before very long should become an accomplished fact. The results of this change should be instantly felt throughout the length and breadth of the land, and a great impetus be given to foreign investment and commerce.

The four other needs, which may be now considered necessities, and which, if appearances be correct, are likely shortly to be supplied, are more railway lines, the settlement of all foreign claims, the extension and improvement of the public highroads, and means for making known in Europe and America the natural riches of the country.

The fifth Pan-American Medical Congress met in Guatemala City in I908, and was largely attended by representatives from all over the continent. A national exposition was held during the same year, and proved both interesting and instructive to the large number of people, chicfly from the countries of North and South America, who journeyed to this capital to see what Guatemala had to offer, and what she required from the outside world. 



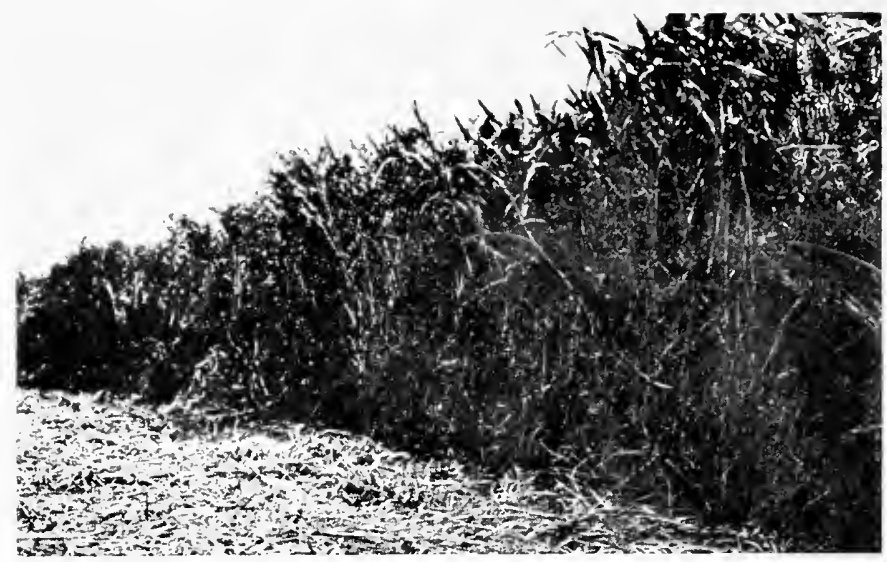

A typical P'lantation of Maize, Guatemalan P'acific Coast

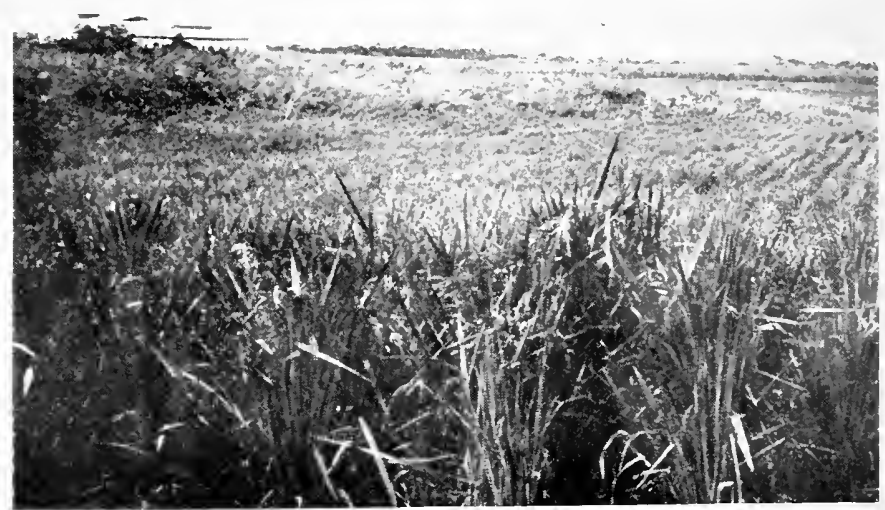

A typical l'lantation Scene on the Cuatemalan l'acific Cuast 
There is little doubt that the healthy climate of Guatemala City, and its steadily increasing size, commerce, and importance, will, in a few years, raise it to a position of equality with the other great capitals of the South ; and it is entirely due to the energy and progressive nature of the inliabitants, to the educational facilities everywhere offered, and to the indomitable spirit of the nation's leader, that the capital to-day is, beyond question, the first city of Central America. 


\section{CHAPTER X \\ GUATEMALA CITY \\ Life in the Capital}

THE most elegant city, or the metropolis possessing the greatest commercial activity, does not always offer the most genuine attractions of life, nor contain the happiest portion of the country's population ; but in the capital of Guatemala the mode of life is different from that in the incessant whirl of great industrial centres, where, during every minute of the day and night, the noise of the almost perpetual traffic jars the tired nerves, and where a walk or ride offers no inducements, owing to the monotony of the never-ending piles of bricks and mortar. Yet such is human nature, that the possessors of one require the other. The people of Guatemala City are striving daily to increase the size and commerce of their capital, with the result that much of the picturesque old-world air annually disappears, and in its place comes the hum and buzz of machinery, the flash of electric light, and all the whirl and bustle of busy life.

Yet, in spite of modern improvements, to many travellers it is still old Spain that will come to mindthe Spain of the Moors, and the sunny plains of Andalusia-as he passes the deep-set, heavily barred winaows, and through the broad porch catches a glimpse of the arches of a colonnade around a patio bright with flowers, and cooled by the chequered shade of trees. While such evolution as that above described is taking place in this young capital of the New World, those who live in the great cities of Europe are always endeavour- 
ing to snatch every square foot of available ground for the planting of a tree, or are expending their cnergy upon the exploitation of a garden city, wherein to lead a simple life. This should be a warning to rulers and statesmen who desire a great capital, and whose foresight and vivid imagination discern, in the acres of brick and mortar and whirling machinery, a national prosperity and greatness. It should be remembercd that there is a limit to all things. As the political economist points out, in the diminishing returns in agriculture, nature yields increasingly up to a certain point, beyond which all further capital and labours yield ever a less return. So it is with almost everything in cities. To go beyond the maximum point leads to increasing insanity, to crime, and to poverty. Let the New World learn from the experience of the Old, which seems to have proved that it is more profitable and certainly more inducive to contentment and happiness, to have many large cities, rather than one huge metropolis with but few other important centres.

The English and Americans in Guatemala City are principally occupied with commerce and finance, while the Germans devote themselves mostly to agriculture in the surrounding country.

American influence and finance is considerably increasing throughout the whole country, owing principally to the lack of enterprise shown by British merchants and capitalists in matters Guatemalan; and German labour, and investments in banking and agricultural undertakings have been steadily on the incline for many years, though the predominating country, from all commercial points of view, is undoubtedly the United States.

The daily life of the inhabitants of the capital differs little from that of other Spanish-American cities. The best hours of the day are those between sunrise and noon, and after sunset in the evening, although, during the 
hottest portion of the day, the temperature is by no means unbearable. The maxim " Early to bed and early to rise " is certainly practised in Guatemala, especially by the agricultural and commercial portion of the population. The reason for this is not far to seek. The cool hours of the early morning are like a delightful summer in England; consequently the business men of the capital usually rise about four or five o'clock, and commence business at six or seven. From this early hour, to about midday, trade is brisk; at that hour the sun, directly overhead, makes exertion very tiring, and a siesta is enjoyed by nearly all classes. With the sinking of the sun energy and vigour return, and business once more revives. The working hours of the whole country may be said to begin at six, or even five o'clock, and to last till twelve o'clock. The evening is often spent either at home or at the houses of friends. For hospitality Guatemalans are justly cclebrated, and even foreigners, provided that they possess good credentials, need never feel dull through want of friends or invitations.

A symbol of those charming Guatemalan qualitiesfriendliness and good will-is the native readiness to shake hands. Quite a large amount of time is taken up by it. You mect your friend in the street. He shakes your hand. You ask after his health. He shakes your hand. You ask after his wife's health. He shakes your hand. You wish him "Good-morning." He shakes your hand-and this, in spite of the fact that, in the office outside which you are standing, he has just shaken hands with a dozen persons, including three strangers, and will do so again when he returns, ten minutes later, merely to give them a message he had forgotten. To Guatemalans this is but a natural expression of national amiability, and as such we can respect it. The South American republican is no churl.

And what sort of a house does this cordial person call 
his home? At first sight it is rather a threatening building. The cntrance is guarded by a heavy door, studded with large nails, through which every person, whether aristocrat or tradesman, finds admission to the patio or centre court. Charming little gardens some of these patios are, bright with colour and fragrant with the scent of many flowers. Here, two steps distant from your sitting-room, you may bask in the sun, or fan yourself in the shade, as inclination may prompt. A native lady, especially if she be very pretty, passes much time here. Beauty is apt to create rather an unpleasant amount of attention in the streets of Guatemala City. Young dandies and scarlet students of the Military Academy will use their eyes.

Towards sunset, at the cool of the day, the ladies, dressed in their very best, may be seen at the windows, or in the balconies, firing glances at all and sundry, but especially at the men-a stare so serious and sustained that it often makes an English man or woman feel selfconscious, but has no effect upon the more hardened Guatemalan. Sometimes the stared-at one will recognise a friend at the window, and will stop to chat for a moment-merely to the mother. But, should the bright eyes beside the mother be more than usually bright, the young man may make it convenient to pass that way again, quite frequently in fact, until things happen, for good or ill, according as his social position, character, abilities, and wealth, or want of wealth, may determine.

A visit to the National Theatre is, perhaps, one of the best ways of observing the composition of society and the state of social culture. The handsome subsidy granted by the Government to the management enables that body to secure, during the season, the visit of several good Spanish and Italian theatrical companies.

Here, as in all Spanish-speaking states, musical plays are much preferred to drama, and the visit of an Italian opera company is the signal for all the 
best in Guatemalan society to secure seats at the National Theatre.

The decoration and carving of the Theatre National is by no means beautiful, but the building is spacious, the stage well furnished with modern theatrical appliances, and the prices not at all excessive, considering that the artists have to make a special journey of several hundreds of miles: coming, in many cases, from Mexico.

It is often a great surprise to foreigners, who have only just arrived in Guatemala, to see here the chic Parisian dresses of the ladies, and the well-cut suits of their male companions ; the courtesy and well-bred manner of the occupants of the stalls and boxes, and the atmosphere of luxurious ease which secms generally to prevail; although a critical observer, used to English or American audiences, might notice, perhaps, a great freedom of intercourse between the sexes, and an undue amount of staring at some beauty or important political personage. But, excepting this, and a loud hum of excited conversation, such as one hears in the opera houses of Paris, Vienna, or Madrid, before the performance commences, the social culture of a Guatemalan audience, composed of the élite of the capital, is equal, in every way, to that of London, New York, or Paris.

The late President, General Barrios, while walking with the Minister of War in the garden or plaza fronting this theatre, was injured by the explosion of a bomb loaded with bullets, and thrown by an assassin, who had previously been convicted of conspiracy, and pardoned.

The General, although severely wounded by the flying lead, uttered no cry, and, calmly smiling, continued his walk for some distance, then drove to the Executive Palace, where he was attended by the doctors.

Since this great and warlike leader's death, life in the republic has assumed a much more settled and peaceful 
aspect. The former state of things was, however, in no way due to General Barrios, who was one of the wisest and best administrators that Guatemala has ever known; but the settling of the country and the advancement of refined civilisation are the outcome of education and the able management which, for so many years, has been the fortunate lot of this little hard-working republic.

For more than half-a-century it has been the great desire of many Central Americans to see the five sister republics of the isthmus joined together by a bond of union, which, they confidently assert, would grow stronger and stronger year by year, until there evolved one great nation-the United States of Central America.

It was in this cause that President Barrios eventually lost his life, dying on the field of battle when leading his troops into action, with the idea of establishing, by force of arms, the union throughout the isthmus.

Many years have now passed since this memorable affray, and the populations of these republics have gradually been drawn into closer and more friendly relationship, with the result that, at a conference held at Washington, it was decided to establish a Court of Arbitration at Cartago, Costa Rica, with the idea of minimising the risk of war between the signatory powers, and ensuring the observance of this treaty, by its countenance and recognition by the United States.

It was also decided, at this conference, to establish a Central American International Bureau in Guatemala City. The opening of this new institute, which took place in September I908, is undoubtedly an important step in the direction of a great and lasting Union between the five republics of Guatemala, San Salvador, Honduras, Nicaragua, and Costa Rica.

The honour of bringing about this good understanding belongs entirely to President Cabrera, whose ambition it is to see established, by peaceful means and with 
general public assent, the Union of Central America. In Guatemala City, the opening of this Bureau was cclebrated by much public rejoicing, and, in order that the importance of the enterprisc may be realised, it will suffice to quote the objects for which the bureau was formed.

(I) The peaceful reorganisation of the Union of Central America.

(2) The introduction of a Central American system of education, which shall be popular and up to date.

(3) The development and extension of the home and foreign trade of Central America.

(4) The increase and development of agriculture, and of the industries which may be of benefit to each state.

(5) The reform and uniformity of civil, commercial, and penal codes, recognising, as fundamental principles, the inviolability of life, the respect of property, and the rights of persons.

(6) The reform and uniformity of the customs services, and of the monetary system, in order to secure a fixed rate of exchange.

(7) Sanitation in general, and in particular at the ports.

(8) The improvement of Central American credit.

(9) A uniform system of weights and measures.

(Io) The placing of real estate on a firm and inviolable basis, in order that it may serve as a foundation for credit, and permit of the establishment of mortgage banks.

The inauguration of this Bureau, by President Cabrera, on I5th September I908, was an important event in the history and life of the republic. Nearly every prominent citizen of the capital has a strong desire for the re-establishment of the Union, and it may be of interest to give here an account, from an official publication, of the opening ceremony and the speech of the President. 


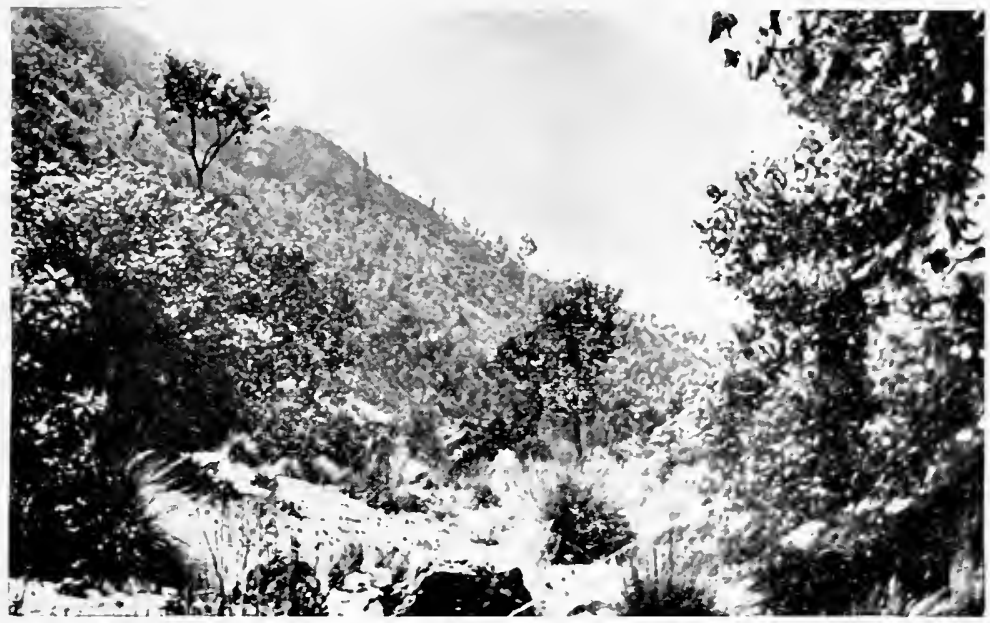

The Slopes of "Santa Maria" from the "Talley of Fertility," Guatemala

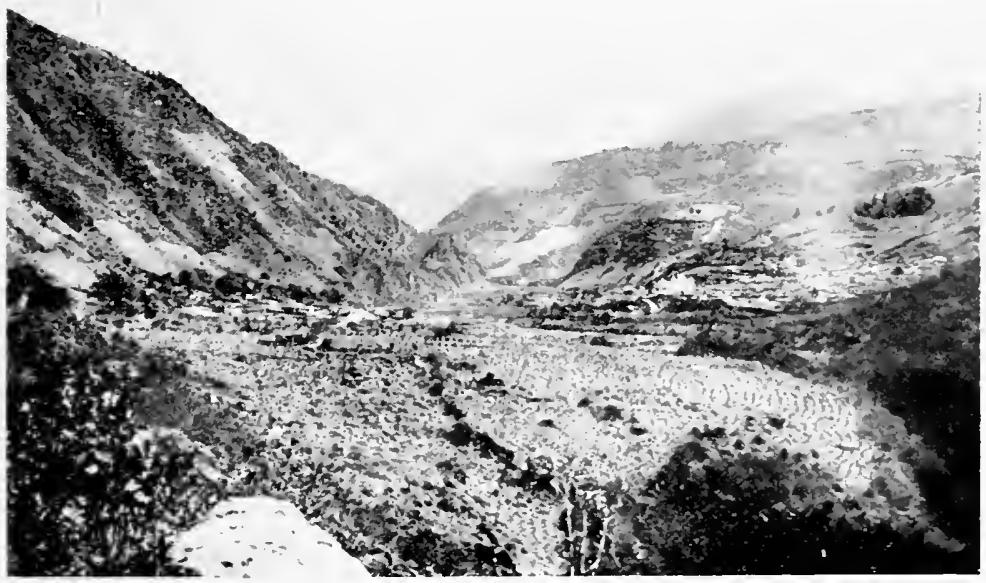

In the Fertile Highlands of Guatemala 

Solemn was the moment when the President of Guatemala administered the oath to the delegates of the International Bureau, with the following formula :-

"Delegates of the International Bureau of the Central American Republics: Do you declare on your honour and for your common country that you will fulfil, well and truly, the great mission conferred upon you by the countries of Central America, to form the International Bureau of Central American Republics ?" - "Yes, we do!"- " Your country and history will do justice to your acts."

And the Latin race, and humanity at large, will justify them or anathematise them according to their proceedings, for it lies in their hands to give to the world a new nation, strong, vigorous and rich, the hope of a very near future.

The building which the Ministry of Foreign Affairs has prepeared for the Bureau is the palace which served as a dwelling for the reformer, General Barrios, when he set out, with the impetuosity of a great man, on his campaign to implant the Union.

Throughout the republics of the isthmus, particularly in Guatemala, this happy event was celebrated with popular fêtes. The people were the first to realise the magnitude of the work which has begun.

All social classes, without distinction, took part in the rejoicings. One of the most significant and pleasing features was that provided by the military element of the capital, who organised a night procession, formed of the various corps of the garrison, with their bands, and at the head of which, surrounded by torches and fancy lamps, marched five officers carrying the flags of the five sister republics.

The ceremony of inauguration of this new international institute took place amid thunderous applause, and the strains of the new Central American Anthem. Guatemala City was $c n$ fête in honour of the occasion. 


\section{SPEECH OF THE PRESIDENT OF THE REPUBLIC}

\section{AFter ADMINISTERING THE OATH OF OFFice TO THE DELEGATES}

"I have just had the immense satisfaction of declaring open on this memorable date the International Bureau of the Central American Republics.

"With what enthusiasm, emotion, and hope does Guatemala welcome this Institution, arising out of the recent treaties signed at Washington!

" The People of Guatemala feel that this event, which is, in a manner, complementary to the Independence, will undoubtedly bring about a bright future for the Isthmus of Central America, since, being of the utmost significance in the true policy of the several States, it will pursue one ideal for the welfare of all the people of the former and still unforgotten union.

"The drawing together of these by peace and harmony, by identity of aims and aspirations, the suppression of theories more or less acceptable, of conventions more or less enduring, the disappearance of opinions more or less exaggerated and not uninspired by interest and greed, and replacing this by the common effort and the practical and efficient work of a united will, animated exclusively by the desire to render effective those aspirations by means which are advised by justice and reason-such will be the effects that, notwithstanding incredulous and mistaken criticism, will be brought about by that unavoidable law which leads to the opening of a way, even though with violence, for the progress of new nations.

"This is what we look forward to with faith in the triumph of a great cause : we who feel pleasure in contributing our share towards the triumph of such causes, we who see, in the rising generation, free from petty interests, an element which will find, in the practical 
development of the events carrying us towards the union, a solution of what is by far the most important question of the politics of the Isthmus. May I be allowed in conclusion to have one further very great pleasurethat of cordially congratulating the delegates on the honour that has been conferred upon them by their respective countries and governments, and of expressing my sincere wish that patriotism may guide you in all your proceedings and that these may lead to a satisfactory result."

Before passing on to everyday life in the capital it is opportune to say something of the various national and religious fêtes, which, forming, as they do, important events in the lives of the inhabitants, give a fair conception of the true sentiment of the Guatemalans en masse.

The popularity and great importance of the Fêtes of Minerva, or annual scholastic celebrations, merit a separate chapter for their description, for they undoubtedly form the longest, most praiseworthy universal rejoicings of the year.

Although the predominating religion of the whole country is Roman Catholic, complete freedom of thought is permitted, and there are one or two other denominations that hold services in the large cities of the republic.

Many religious fêtes and processions are held during the year, and these are usually well attended by all classes. Notable in these fêtes is the admiration of the native population for bright colours and impressive and mystic ceremonies, at which the Spanish-Americans look on, or in which they take part, with an air of indifference, sometimes even of amusement. Yet beneath the surface runs the same feeling of devotion to the belief of their forefathers, and to the State religion of the Spanish kingdom.

Independence Day, the I5th of September, is cele- 
brated throughout the republic by a general holiday. Military reviews and patriotic processions take place in the capital, and, on these occasions, public rejoicing often lasts late into the night.

The shops of Guatemala City cannot be classed among its most notable features. In many cases they are small, and contain only a meagre selection of modern novelties; not so, however, with the markets, where the bulk of the trade is carried on. Here may be seen the greatest possible variety of national and foreign productions.

The central market is a large roofed structure, the interior of which presents a busy and interesting scene. Almost everything can be purchased here, from guns and saddles to fish and vegetables. One of the most interesting exhibits to travellers is perhaps the native pottery, which, although crude in workmanship, and often grotesque in design, is sometimes cleverly decorated ; likewise the small, richly embroidered jackets so eagerly turned over and examined by dark-skinned girls, whose docile countenances seem to light up, and their bright eyes to sparkle with pleasure, at the very sight of such a medley of bright colours, against which their own black tresses show with such striking effect.

The entrance to the market, the building itself, and the space outside, are filled with sellers, mostly women, whose quiet voices-the place is much less noisy than one would expect-fill the air with a quiet hum. When, after a look round, you are tempted, as you surely will be, to try some of the delicious fruits that in anticipation have been moistening your mouth ever since you came there, you must be wary. Remember that you are not in England; and when the large-eyed, dusky lady names a price, even though it seems to you a very moderate price, lift your eyebrows, and turn down the corners of your mouth. Then it will be your turn to name a figure-and, curiously enough, if you are wise, your figure will be exactly half that quoted by the dusky 



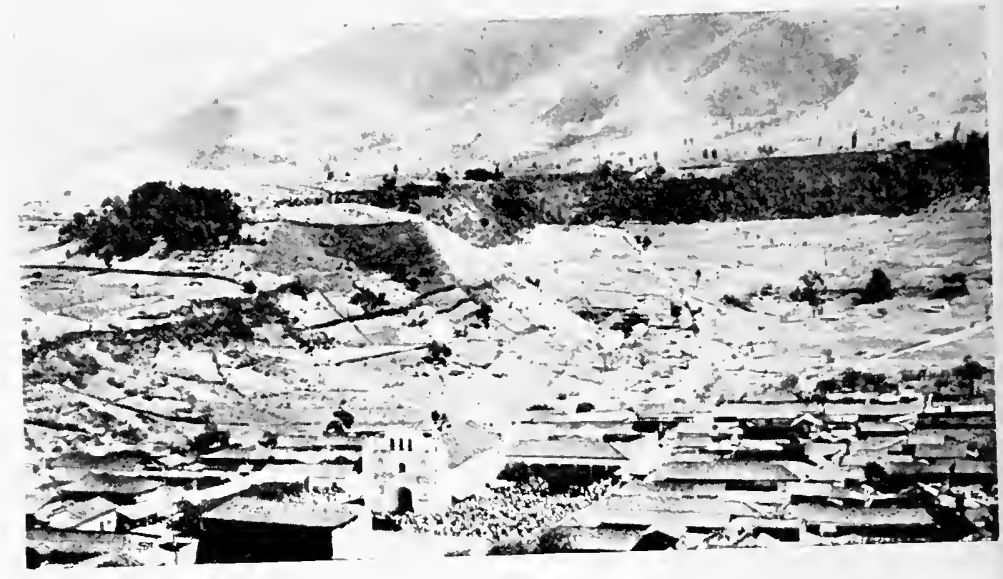

Cantel, from the surrounding I Ieights, Guatemala

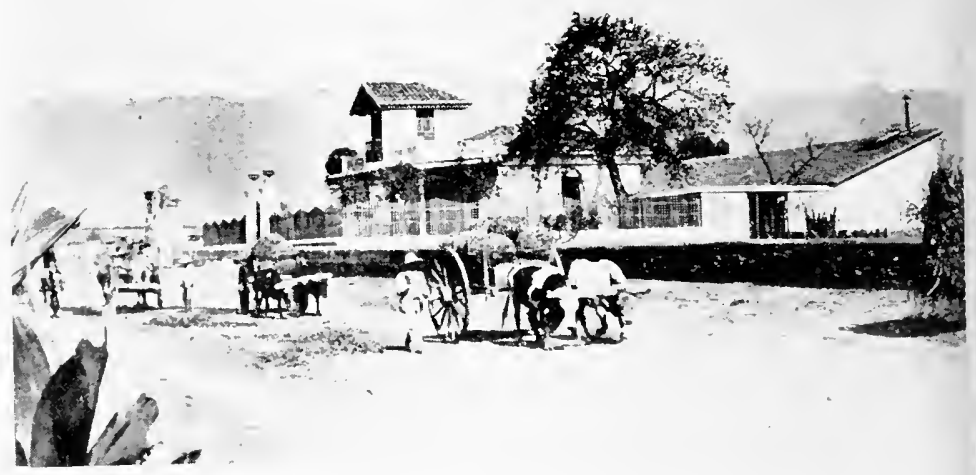

A typical Roadside Scene in the Guatemalan Highlands 
lady. But, for all that, it will probably be accepted. Such are Guatemalan methods.

Should this glimpse of the Indians in the capital have tempted you to see more of them, pass outside the city, on to one of the main roads, and watch the coloured frieze of natives, in single file, sliding down the road to Guatemala City-men and women heavily burdened, with packs upon their backs, market baskets of fruit and vegetables upon their heads, fowls, or even live pigs, slung about them, and sometimes a family of little brown-legged children, chattering at the mother's heels. They' are of the old stock, these Indians, earning their living just as their ancestors earned it hundreds of years ago.

A form of exciting amusement, now rapidly waning in popularity, is the bull-fight. For many years this Spanish national sport, as practised in Guatemala, has been of a very humane character, neither the bull nor the toreadors being killed in the performance. The horns of the animal are rendered less formidable by the addition of large, padded, wooden balls, and the performance consists merely of teasing the bull and avoiding its onslaught. Games in the Plaza de Toros now seldom take place, and although there is no law at present prohibiting these fights they have, by general consent, almost entirely disappeared.

The native population amounts to about fifty per cent. of the total ; but these hard-working and docile people, under able administration, have attained such a standard of civilisation that they now are an important factor in the commercial and agricultural prosperity of the capital, and, in fact, of the whole country. Too much praise cannot be given them for their honesty and general trustworthiness.

The supreme municipal authority rests with the Jefe Politico, who may be termed the Governor of the city, and is responsible for all local matters. The 
policing of the capital is ably carried out, this important branch being usually under the direction of a chief of police, who has had experience either in New York or in one of the large cities of Europe or the United States.

Very little crime is perpetrated in the capital, and with the possible exception of a few political discontents, who dwindle in number every year, it is remarkably free from acts of violence or larceny.

Anyone who has watched the growth of this city, and its steadily increasing prosperity, cannot but feel that, whatever may have been its past-for, like the capitals of all young countries, Guatemala City has passed through troublous times-a prosperous future is now assured to it, as the great commercial and industrial capital of the rich countries of Central America. 


\section{CHAPTER XI}

\section{THE FÊTES OF MINERVA}

For many years past President Cabrera and his Government have directed much attention to the reorganisation of the educational system, and it may now truthfully be said that, in this important respect, Guatemala stands far ahead of all the other countries of the isthmus, and on an equality with the most advanced states of Spanish America.

There are no less than 1262 schools scattered over the whole republic, and in addition to the professional colleges of Medicine, Law, Pharmacy, Elocution, Engineering, Drawing, Painting, and Music, there are : the Polytechnic, the Academy for Young Ladies, a school for natives, Occidente Institute, the Oriente Institute, and the Normal School for Young Ladies at Chiquimula. There are also schools of commerce, trades, and fine arts, as well as evening classes for the working population engaged during the day.

The Fêtes of Minerva, called Minervalias, are held, throughout the whole of the republic, at the close of each scholastic year. These somewhat unusual, though worthy, celebrations, which were founded by President Cabrera, on 8th October I889, with the laudable object of giving an incentive to education, and also as a public tribute to the professors and students, have been the subject of universal praise, by reason of their elevated aims. In the Album of Minerva, an art souvenir published on these occasions, may be seen congratulatory messages from many of the greatest 
statesmen, politicians, writers, and poets of the world. Among these contributions are the following few lines of wisdom from that eminent citizen of the United States, Theodore Roosevelt:-

"That education which properly fits a people to do successfully, whatever part in the world's work comes to them, is the surest means of continuing the upward progress of civilisation."

The Festival of Minerva, which is cclebrated in every city of the country, by several days of public holidaymaking, has for its headquarters a temple dedicated to the Goddess of Wisdom. In the smaller towns of the republic the plaza, decorated with flags, festoons, and palm-tree arbours, takes the place of the more costly temple.

In Guatemala City, the Temple of Minerva is situated at the top of the Avenida del Hippodromo, and is an imposing structure of classic architecture, which, during the days of these fêtes, is emblazoned with the emblem of the republic, and decorated with blue and whitethe national colours. The streets of the capital also are gay with colours, and on each side of the Avenida de Minerva-a fine, broad promenade facing the Temple - are erected ornamental kiosks for viewing the numerous processions. These are used for music and dancing in the evenings. 1

It may prove interesting to give here the programme of this festival in the capital, which not only shows its attractive and up-to-date character, but will enable the reader to see clearly the happy combination of amusement and instruction which is the characteristic of these national fêtes.

1 "Holidays in Guatemala City." Guatemala City has plenty of holidays; perhaps, some would say, too many; yet not enough to justify you in quoting the ancient proverb to the effect that Spanish holidays number three hundred and sixtyfive, exclusive of Sundays. 


\section{THE FÊTES OF MINERVA 117}

\section{GENERAL PROGRAMME ${ }^{1}$}

\section{5th OctoBER}

I.-At 5 A.m. the bands will parade through the principal streets playing martial music, announcing the festival of the youthful students.

2.-At 6 A.M. the national flag shall be hoisted on the palace with the customary honours, for which purpose the military bands will be stationed in the Plaza de Armas.

3.-From 6 to 7 breakfast shall be served to the pupils in the respective National Establishments, and from 7 to 8 every school shall proceed to its appointed place in the said Plaza.

4.-Having assembled there, all the public and private educational establishments of the capital, and the ranks being properly arranged, they shall start punctually at 8 o'clock, in procession towards the Temple of Minerva.

5.-After taking up the places assigned to them, the various educational institutions shall proceed to unveil the medallions which it was resolved to place in the Palace of Minerva as a tribute of homage to Drs Antonio de Liendo y Goioechea and José Farfán ; the pupils of the public and private schools, meantime, singing the National Anthem, and the standard of the republic being hoisted with the prescribed honours.

\section{Matute.}

6.-Official oration delivered by $\mathrm{Dr}$ Juan Padilla

7.-Presentation of colours to infantile battalion.

8.- Lunch to the pupils.

9.-Opening of the Zoological Exhibition dedicated to the children, and a discourse on the subject by Professor Miss Victoria Espinoza T.

Io.-At night, illuminations, music, "cinematografo" and fireworks in the Avenida de Minerva.

${ }^{1}$ From Guatemala Post. 


\section{6th OCTOBER}

I. -At I P.M. opening of Exlibition of Fruits and discourse by Professor Miss Mercedes Andreu.

2.-Manœuvres and evolutions by the school children.

3.-Presentation of prizes, given by the army, to the three pupils of the elemental boys' schools of the capital most proficient in calisthenics.

4.-Distribution of fruit to the children.

5.-At night, " cinematografo " illuminations, music, dances and fireworks.

\section{7 th OCTOBER}

I.-At I P.M. opening of Exhibition of Flowers and Ornamental Plants, and discourse by Professor Miss Julia Bertrand.

2.-Lunch given by the committee of ladies of the capital to the pupils of the public schools.

3.-Ribbon races.

4.-At 4 P.m. battle of flowers.

5.-At night similar diversions as on previous nights, and torchlight procession in Avenida de Minerva.

\section{8th OCTOBER}

I.-At I P.M. rifle practice of the school of arms.

2.-Gifts of toys to the pupils, from the banks, agriculturalists and merchants.

3.- - Horse races.

4.-At 8 P.M. punctually, concert by all the professors of the orchestra of the capital, and great illustrated conference in the Palace of Minerva.

About I50,000 people usually congregate in the capital, to watch or take part in this festival, and some 


\section{THE FÊTES OF MINERVA 119}

5000 to 7000 prettily dressed children are included in the numerous processions.

Guatemala City and many of the large towns of the republic are gaily decorated with flags, flowers, and palm leaves. Triumphal arches, banners, and flagpoles line the principal streets, and the president and his ministers address the students in the Temple of Minerva.

The Press of almost every nation has been loud in praise of these scholastic fêtes, which have done so much towards promoting education in the republic of Guatemala. 


\section{CHAPTER XII}

\section{THE FAMOUS RUINS OF ANTIGUA, QUIRIGUA, AND UTATLAN}

ONCE the most important city of Spain in Central America, now a chaotic mass of picturesque and interesting ruins, Antigua, the ancient capital of Guatemala during the Spanish regime, nestles amid the cloudcapped peaks of the Sierra, with a new town rapidly springing up phœnix-like from the old.

What lessons of bygone times may be learned from these crumbling walls that, for nigh four centuries, have resisted fire and flood, and Time's effacing hand! Some churches, yet standing, bear the cross and papal arms, together with the symbols of the Inquisition; the ancient palace of the viceroy is still emblazoned with the royal arms of Spain. One cannot gaze upon these majestic ruins without picturing, in mind, this city when Spain was in the zenith of her power-the quaint, tiled streets, filled with adventurers clad in the picturesque dress and bright colours of olden Spain ; dark-eyed girls, with faces hid beneath the mantilla; cringing Indians, whose only lrope was in escape, when possible, to the mountain fastnesses; long processions of black-hooded friars, whose word meant life, or death by torture, to the suspected heretic; the invincible soldiers, booted and spurred, who bowed the head in fear to the meanest friar wearing the white cross of the Inquisition, and yet without a tremor faced death in a thousand forms upon the field of battle. Truly, a curious contrast, when compared with the Antigua of 
to-day, whose yellow, crumbling walls, bright in the glare of the sun, recall those famous lines of Scott :

"The battled tower, the donjon keep,

The flanking walls that round them sweep,

In yellow lustre shone."

These famous ruins, and the new town of Antigua, stand in a sheltered valley some twenty-five miles from the present capital of the republic, at the base of two mighty volcanoes, named "Fuego" and "Agua" - "Fire " and "Water." It was the deluge from the lake on the summit of the latter, loosed by a violent earthquake, which, in July I773, destroyed the old capital and the adjoining town of Ciudad Vieja, and caused the seat of Government to be transferred to the flat, open plain upon which Guatemala City now stands. It is curious to note that the two towns, Antigua and Vieja, the first and second to be established in Guatemala by the conqueror Alvarado, were destroyed by earthquakes, accompanied by fire and water, when at the summit of their splendour and of their iniquity.

It was a fair city that, by the forced labour of conquered Indians, rose in brick and stone from the lovely valley, shadowed by the two great volcanic peaks that were to spout down death upon those who had broken their pledged word and invaded a nation's rights. In one night of thunder and lightning, of frightful rumblings of the earth and dreadful rushings of waters, Antigua was overthrown and laid waste.

Looking up to-day at those mighty peaks, cold now and dead, yet still threatening in aspect, we cannot wonder that the natives have ever looked upon them with awe as the home of beings powerful to affect for good or ill the lives of men.

Formerly, when the volcanic upheavals had been severe, the natives would seize, here and there, a fair 
maiden from her village home, lead her up to the coneshaped hill, and cast her down into the crater below, that her shade might appease the spirits of the angry gods. Later, after the coming of the priests, brilliant processions might have been seen wending their way among the mountains, that the power of the cross might succeed where the spirit of a maid had failed. But still the gods stormed from their thrones, and the Church conceived the idea of taming these wild spirits by baptism, and by formal reception into the fold of St Peter. This method was for a time effectual ; the hills, said the people, were converted. Then one day Santa Maria, saintliest of them all, broke out again into smoke and fire, until her last state was worse than her first.

The mountains of Guatemala, as a whole, though not always rugged and snow-capped like the Alps, have a weirdness and fascination keenly felt, yet hard to describe. Cacti-like trees rear thorny, spreading arms from their slopes, and often down into the valleys below run hot sulphur springs.

Some of these springs and pools, upon the surface of which bubbles of gas are bursting, yield water too hot to be drunk, until it has been standing for some time. Then it is not unpleasant, though rather sulphurous to the taste. Natives will tell you that hot, sulphurous water renders the taker immune from fever. The native washerwomen naturally revel in this provision of a kind nature that saves them both time and fuel ; and I doubt not that, in their belief, sulphur has quite a beneficial effect upon dirty linen-a subject upon which I am not sufficiently informed to venture an opinion of my own.

I should like to quote here Mr Maudslay's description of a sight that is well worth the effort involvedsunrise as seen from the crater of Agua.

" The world lay still asleep, but just stirring to shake off the blue-grey robe of night which had thrown its 


\section{FAMOUS RUINS}

soft grey misty folds over lakes and valleys. A magnificent panorama of mountain peaks floated out on the mist, east and west and north, whilst to the south a grey haze stretched away until it was lost in the mists of the ocean. Following the line of the coast the great bulwark of volcanic cones stood shoulder to shoulder, and in the far east we could just catch the faint red light from the active crater of Izalco in Salvador reflected on the morning sky. One by one the lofty peaks caught a pink glow from the coming sun, and as the mists rolled away we could see the pretty lake of Amatitlan nestled among the hills and the sleeping hamlets dotted over the plain. Very near to us on the west towered the beautiful volcano of Fuego, still clothed in the softest blue mist. As the sun rose clear and bright we beheld a sight so interesting and beautiful that it alone would have repaid us for the miseries of the night, for at that moment a ghost-like shadowy dark blue mountain rose high above all the others, and as we gazed, wondering what this spectral visitor might mean, we saw that it was the shadow of Agua itself projected on the atmosphere, which moved as the sun rose higher and gradually sank until it lay a clear-cut black triangle against the slopes of Fuego."

But we must return to Antigua. Many curious stories are told by historians of churches connected with nunneries by subterranean passages, and of female skeletons discovered in the massive stone walls of many a fallen abbey.

A close inspection of these extensive ruins shows what must have been the architectural magnificence of the former capital. The lofty arch of the cathedral entrance is handsomely carved, and outlined with bevelled and seemingly twisted stone; small columns support the arches above, and the niches are occupied by sculptured angels and other Scriptural figures. The ruined walls and pinnacles of over seventy churches, 
monasteries, and nunneries may be seen from the cathedral precincts.

Over all this mass of broken stone, and on the jagged walls, Nature has asserted her dominion: grass grows from every crack; from each cranny many varieties of brightly coloured flowers, small bushes and trees even, sprout with vigour and luxuriance from their hard, damp, rocky beds.

The stone carvings, decorated tiles of antique Spanish design, coats-of-arms, and inscriptions, together with the handsome interiors of several of the churches and other edifices, still standing, and in a wonderful state of preservation, make these extensive ruins a veritable delight for the antiquarian, and a place of the greatest charm and interest, even to the casual, comparatively unlettered globe-trotter.

Around these scenes of fallen splendour a new, and certainly more important, though less interesting, town is rapidly being built. The Antigua of to-day offers but little to arrest the eye of the traveller, yet the skill of the native inhabitants in carving and ornamenting canes, stones, and cocoanut shells, in fashioning miniature figures, and other fine works of primitive art, proves that the lessons given to their forefathers by the Jesuits have borne fruit in the children, who are still Spanish and Quiché in their customs; and so will always remain.

Although 'tis a far cry-some two hundred milesfrom Antigua to the monoliths of Quirigua, situated near Lake Izabal, on the Atlantic coast, we may fittingly say something here about these marvellous and puzzling relics of a bygone age.

These huge stones, some of which, in shape, bear a certain resemblance to Cleopatra's Needle, though they lack the same colossal dimensions, rear their heads like tombstones (which many suppose them to be) among the dank vegetation of the low-lying coast- 
lands. They are carved from the local sandstones, some in the shape of tigers' and jaguars' heads, lifesize, others are tooled in hieroglyphics, which defy transcription, and stand out in bold relief. Some of these stones are still erect, but many are sloping ominously, and not a few are lying prone, neglected and overgrown by the luxuriant vegetation of the tropics.

The following excellent description is from a paper by Mr Maudslay before the Royal Geographical Society :-

"The ruins, which are completely hidden in a thick tropical forest, stand about three quarters of a mile from the left bank of the River Motagua, and about five miles from the miserable little village of Quirigua, from which they take their name. They consist of numerous square or oblong terraces, varying from six to forty feet in height, some standing by themselves, others clustered in irregular groups. Most of these mounds were faced with worked stone, and were ascended by flights of stone steps.

"The interest centres in the thirteen large carved monoliths which are arranged irregularly round what were probably the most important plazas. Six of these monoliths are tall stones measuring three to five feet square, and standing fourteen to twenty feet out of the ground, the other five are oblong or rounded blocks of stone shaped so as to represent huge turtles or armadilloes or some such animals. All these monuments are covered with elaborate carving, usually on both back and front of the monoliths there is carved a huge human figure standing full-face, and in a stiff and conventional attitude. The sides of the monuments are covered with tables of hieroglyphics, most of them in fairly good preservation. In addition to these tables of hieroglyphics there are series of squares or cartouches of what appears to be actual picture-writing, each division measuring about eighteen 
inches square, and containing usually two or three grotesque figures of men and animals. The design of these picture writings shows considerable variety and freedom of treatment, as compared with that of the large figures, in the execution of which the artist seems to have been bound by conventional rules.

"The largest of the stone animals is, perhaps, the most remarkable of all the monuments, its measurement is roughly a cube of eight feet, it must weigh ncarly twenty tons, and it rests on three large slabs of stone. It is shaped like a turtle, and is covered with most elaborate and curious ornament, with tables of hieroglyphics and cartouches of picture writing. The greater part of the ornament throughout these carvings is formed from the grotesque representations of the human face, or the faces of animals, the features frequently so greatly exaggerated that it is difficult to recognise them, but a careful examination enables one almost invariably to trace back to this facial origin what, at first sight, appears to be merely conventional scroll-work. Forms derived from leaves or flowers are altogether absent, occasional use is made of plaited ribbon, and a very free use of plumes of feathers, which are often most gracefully arranged and beautifully carved. The fifteen monuments are divided into two groups: in one the figures are all those of men; in the other of women. ${ }^{1}$ It might be rash to argue from this that women had obtained a high place in the arrangement of the people who raised these monuments; but there is one other feature that certainly may be admitted as showing an advanced and peaceful condition of existence, and that is the entire absence of any representation of weapons of war."

To describe even shortly the many antiquities of Guatemala would require a volume in itself, and with

${ }^{1}$ Mr Maudslay appends a note: "This statement may need further consideration." 
that scope, even, I could give but a very poor and incomplete idea of their interest and historic worth. Among the most important remains, however, must be mentioned the confused pile of debris-for little of value has been saved from the sacrilegious hands of the numerous treasure-hunters--where once stood Utatlan, the great capital of the Quiché kings. ${ }^{1}$ The ruins of the great sacrificial altar are now barely distinguishable, but historical records give graphic, and bloodily realistic, accounts of the terrible tortures and massacres inflicted upon helpless prisoners, as human offerings to the god Tohil. This loftily poised stone daïs, upon which the high priest of the Quichés used to cut out the hearts of his victims, or from which he would hurl them down on to the rocks below, has been levelled nearly with the soil, and but little remains of a city which must have been almost as old as those of the Aztecs of Mexico.

The account of the city of Utatlan, given by Fuentes, at the time of the Spanish Conquest, leads us to believe that the Indians of Guatemala were little, if at all, inferior to the natives of Mexico or Peru, and that their city was worthy to rank with those of rival American countries. The population appears to have been so large that no less than 72,000 of its citizens joined in the battles against the Spaniards. In the centre of the town stood the royal palace, surrounded by houses of the nobility. Torquemada, probably exaggerating, says that it would compete in opulence with that of Montezuma or of the Incas, and that it contained distinct apartments for troops for the king, for the queen, and concubines, and for the royal family, with saloons, baths, gardens, and menageries. all in a style of sumptuous magnificence. Among other large buildings, the finest was the seminary, where between 5000 and 6000 ${ }^{1}$ Situate not far from Santa Cruz del Quiché. 
children were maintained and educated, at the expense of the royal treasury, by seventy masters and professors.

Torquemada, too, asserts that before the arrival of the Spaniards the historical traditions descended over a line of twenty monarchs. The grand council consisted of twenty-four grandees; the principal towns were governed by lieutenants, and every office was filled by the nobles. The greatest care was taken to preserve purity of blood, and any noble marrying a plebeian was at once degraded, and his descendants rendered incapable of bearing office. By the penal laws, the king could be tried by his nobles. "High treason, adultery and rape were punished with death; murder, by being thrown from a high rock; robbery by fire ; arson by death; 'because,' says the Law, 'fire has no bounds.'

In the National Museum, Guatemala City, a moderately good collection of antiquities and works of art is preserved; but, considering the great wealth of interesting relics which may almost daily be seen in every city and small town of the country, much in the way of collecting and classifying yet needs to be done, unless a large number of articles of great scientific interest are to be lost for ever. The natives in the more remote parts often use for everyday purposes ancient and splendidly decorated pottery; and tiles of early Spanish origin may frequently be seen lying about here and there. Small stone images, cleverly fashioned and in a wonderful state of preservation, are used as children's dolls.

This, perhaps, is one of the best misuses they could be put to, as the dark-skinned, laughing little native children need much persuasion, and also recompense, to induce them to part with their stone babies, which probably have already seen and survived many hundreds of years of life in this dangerous world. 


\section{拄}

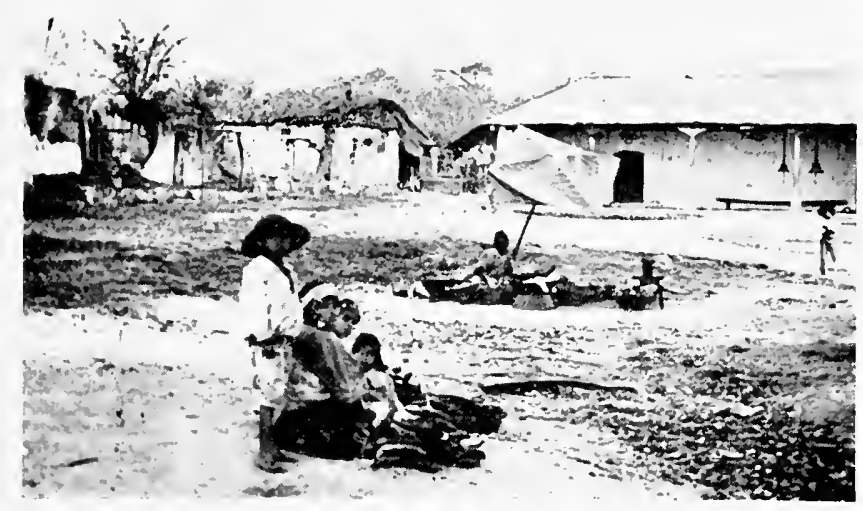

Native Huts, Palmar, ciuatemala

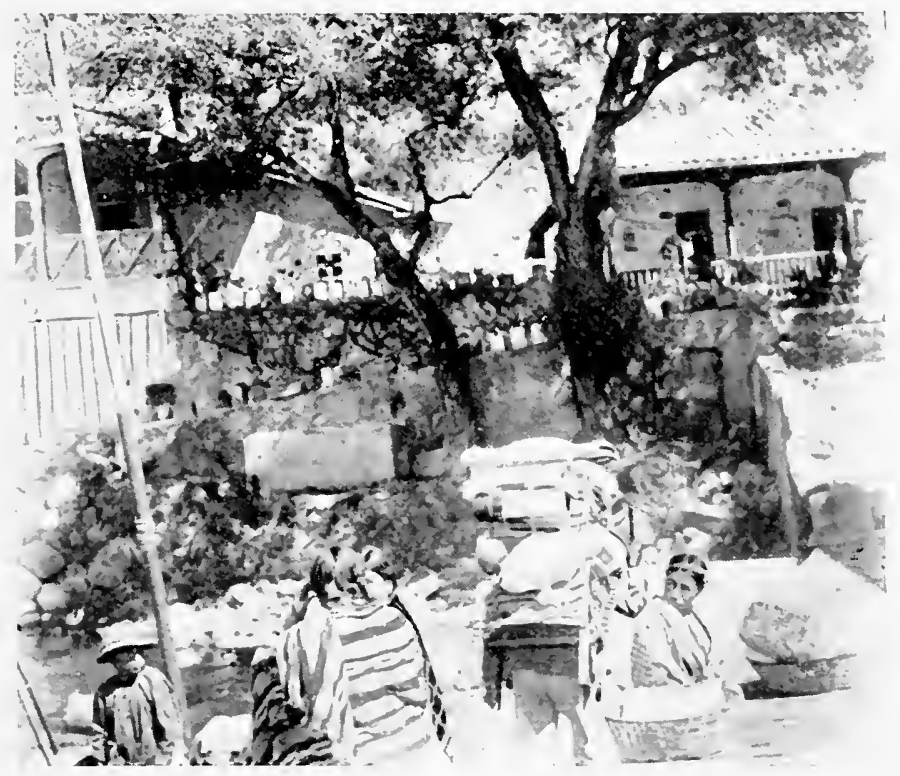

A lomestic Scene (native) at Tzanhuji, Guatemala 

Calvaries and other religious edifices of a more recent date are dotted about all over the country; in fact, the remains of these buildings form an almost complete history in stone of the time when Guatemala, and practically the whole continent, was ruled from the Vatican at Rome. 


\section{CHAPTER XIII}

\section{THE PACIFIC COAST}

AT a distance of seventy-five miles south-west of Guatemala City lies San José, the chief port on the Pacific coast of the republic. It is connected with the capital and the Atlantic seaboard by the joint undertakings forming the Transcontinental Railway, which gives it by far the largest portion of the maritime commerce of the country.

San José cannot be called a fine city, as there are but few buildings over two storeys high, or which possess any artistic or architectural features worthy of note. The generality of houses, paradoxically speaking, are bungalows, the majority built of wood or white stucco-work. The streets run at right angles to each other, with the inevitable plaza as the municipal centre.

Perhaps the most notable feature of San José is the long pierlike wharf stretching out into the sea for some two hundred feet beyond the surf; but, unfortunately, as is the case in many other South and Central American ports, there is no harbour.

Ships, lying off in the roads, load and discharge passengers and cargo by means of large lighters and small steam tenders, which ply between the wharf and the vessels lying at anchor. This method, however, is not altogether satisfactory, owing to the heavy sea which often makes landing very difficult, and sometimes impossible.

San José does not depend upon the passenger traffic for the bulk of her revenue, nor does she owe to this 


\section{THE PACIFIC COAST}

source her proud position, as the most important maritime centre of the country.

It is the rich sugar and coffee fincas or estates, scattered over the whole south and west coast, especially in the near vicinity, that have made San José so prosperous.

Many British ships make this their only port of call in Central America; there is a regular steamboat service with San Francisco, and also with Australia, China, and the Far East. The submarine cable also links San José directly with the outside world.

Curiously enough, the almost world-wide habit of visiting the seaside during the summer months is but little in vogue in Guatemala. This may possibly be accounted for by the humidity of the climate of the lands bordering the two oceans, and also by the impossibility of indulging in that beautiful and altogether pleasant exercise of swimming, on account of the hungry sharks that infest these blue and otherwise inviting waters. But for the last drawback there is no doubt that the youthful Guatemalans would joyfully disport themselves on the sands, and beyond them, in the same manner as their more northern and, in this respect, more fortunate neighbours.

During the summer season the inhabitants of the capital, and in fact of the whole country, take periodical excursions into the mountains, where the cool, refreshing breezes impart life and energy, making this portion of the state one of the most healthy in the world, and where may be enjoyed a never-ending panorama of grand scenery. The country around San José is flat and swampy. In some parts, however, the great variety of palms, and other tropical growths, gives the land a somewhat deceptive appearance of great fertility. Many large coffee estates, sugar, and fruit plantations, and orange groves, cover much of the coast-lands and the low foothills, farther inland. 
Extensive cattle ranches, situated some fifteen miles from the ocean frontier, also occupy many thousands of acres, and form a very lucrative industry; but by far the largest portion of this coastal region is covered by a wealth of tropical growth and primeval forest.

The most important inland towns on the Pacific slope are Mazatenango, situated on the left bank of the Rio Nagualate, midway between San José and the next most important Pacific port, Champerico, with which it is connected by railway; Escuintla, which; like Mazatenango, is a flourishing sugar and coffee centre; and Retalhuleu, an important station on the Western Railway, which terminates at Champerico.

The staple industry of the whole coast is agriculture, although, on the slopes of the Sierra, pastoral farming is yearly becoming more popular.

Before passing on to describe the other seaports, it is as well to say something of the beauties of the famous Lago de Atitlan, which, although situated among the heights of the Sierra, is really on the Pacific coast.

The cool, peaceful waters of Atitlan are surrounded on all sides by lofty mountains, often clothed in cloud, from whose summits roaring torrents descend over rocky beds to empty themselves into this beautiful lake. Sheltered as it is by the surrounding mountains, several of which are volcanic, semi-tropical fruits and vegetation cover its banks with rich green growth extending to the water's edge, and over-shadowing the small creeks with a leafy awning that completely shuts out the sun; thus forming quite a number of cool and enjoyable retreats in which the traveller may shelter from the glare of midday. Small steam launches constantly cross and recross the lake, and many native canoes, of a peculiar type, may be seen dotted over the glass-like surface.

High up in the mountains, overlooking the lake; 


\section{THE PACIFIC COAST}

stands the town of Sololà, famous neither for its architectural grandeur nor for its commercial importance. Yet, when viewed with the sunlit lake, that in the daytime lies spread like a golden carpet at its feet, and at night sparkles silver-bright in the rays of the tropical moon, the whole forms a coup d'ceil of exceptional and quite impressive beauty.

The principal rivers flowing towards the Pacific are the Michatoga, Coyolate, Paz, Guacalate, Samatá, Nugualate, Ocos, and Suchiate. There are also several fine waterfalls that well deserve a visit from any traveller who is fortunate enough to be within striking distance.

To return once more to the coast, the second among the Pacific ports is Champerico, situated some miles nearer the Mexican frontier, and connected by railway, as has already been stated, with the interior towns of Retalhuleu, Mulua, San Felipe, and Mazatenango.

This port enjoys the advantage of being the great shipping centre for the bulk of the coffee and sugar coming from the extensive fincas in the south and west of the country, and its commerce in this commodity is rapidly increasing. It is no unfrequent occurrence for five or six large vessels to be all discharging cargoes of manufactured goods brought from the United States, and each taking in thousands of bags of coffee for the homeward voyage.

About Champerico little need be said ; for it is much like the neighbouring port of San José. It must be remembered, however, that almost every month sees the addition of a modern building improvement; for which reason descriptions of rapidly growing towns are often very misleading.

Within gunshot of the Mexican frontier, at the mouth of the Rio Naranjo, stands Ocos, the most northern port on the Pacific coast of Guatemala. A short railway line, about twenty-three miles long, connectsit with the inland 
town of Vado Ancho, which secures for it the monopoly of the coffee export trade of this portion of the republic.

It is estimated that about 200,000 bags of coffee annually leave this port, besides many tons of hides and rubber. The coast-lands immediatcly surrounding Ocos are low-lying and swampy, but the climate is not altogether unhealthy, and the soil is eminently suitable for the cultivation of sugar-cane, which now forms an important industry, although little of this product is exported, owing to the competition offered by beet-sugar, now so generally used throughout Europe.

The rich coffee-growing districts are situated from twenty to fifty miles from the sea-coast, and the extension of the railway will greatly facilitate the transport and shipment of coffee grown in Northern Guatemala, where may be found some of the largest fincas, and those possessing the most modern machinery, in all Central America.

When the Ocos Railway has been pushed forward another thirty-six miles, a junction will be effected with the lines of the Central of Guatemala, thus not only greatly enhancing the value, and increasing the output of coffee from the estates in the north of the country, but also giving through railway communication with the capital and the Atlantic coast, shortening the duration of transport, and cheapening the cost of exporting this commodity to Europe.

Perhaps the most momentous undertaking in all Central America has now reached the Guatemalan northern frontier from Mexico. This is the PanAmerican Railway system, which, when a bridge has been constructed over the Rio Suchiate, at Ayutla, will be joined by a few miles of road, to the lines of the Central Railway of Guatemala. When this has been accomplished it will be possible to travel by railway from Guatemala City, or almost any portion of the state, to 
the capital of Mexico in about fifty hours; whence the journey may be continued to the United States, or to any part of the dominion of Canada.

It will readily be seen that such an extensive network of railways, connecting the republic with great commercial centres like New York, Boston, Toronto, Montreal, Ottawa, and Quebec, will largely increase the commercial activity of the country.

The physical aspect of the Pacific coast varies considerably.

The narrow strip of land, some fifteen miles broad, which fringes the ocean, is low-lying, flat, and in parts swampy. It is covered with prolific growth, and in places the sod itself is coated with dead leaves and vegetation. There are broad acres, however, which are only suitable for dry cultivation: the parched, sandy soil being only capable of giving nourishment to such thirstless plants as the sugar-cane.

About fifteen miles from the ocean the country assumes a different aspect. The undulating ground, steaming in the torrid heat, is covered with yellowish grass, upon which large herds of cattle lazily browse ; only a few miles farther inland the lofty summits of the Sierra mark the limit of the hot coast-lands. This range runs parallel with the ocean, being distant from it some twenty miles in the south, and about fifty miles in the north-west of the country. A line of lofty volcanoes stand in majestic silence, like outposts, around the commercial centres of the Guatemalan tableland.

Enough has now been said about the Pacific coast to show clearly that, although it enjoys not the springlike climate of the mountains, it possesses, nevertheless, several growing seaports, and is a region of great tropical fertility. 


\section{CHAPTER XIV}

\section{COFFEE-GROWING}

\section{The Working of a Finca}

IT is a curious fact that, although coffee-growing is the staple industry of the country, and over I90,000 acres are planted with coffee-trees, the Guatemalan peasantry fail entirely when they attempt to prepare this beverage for drinking. In certain parts of the country the natives, instead of roasting the coffee, pulverise it, boil it for some hours, and bottle the liquid, which they call essencia de cafe. This concoction, concerning whose merits travellers differ-some coming to like it in time, while others, myself among them, detest it cordially-is served at table with boiling water, as the real thing.

In remote districts this beverage is often kept in, and served from, a patent-medicine bottle, with a corn cob or a roll of paper for a stopper. The smell, as $\mathrm{Mr}$ Brigham happily remarks, reminds one of that of a newly printed newspaper. The taste is so strong and bitter that travellers have been known to pour it on the ground thinking it was poisoned.

Although this is the case with the native population of the countryside, who are often the labourers on the coffee estates or fincas, in the cities and towns, or in the planters' magnificent residences; one may enjoy coffee à la Parisenne.

There are about six thousand coffee estates situated all over the south, centre, north and west of the country, many of which comprise hundreds of acres planted with 
thousands of trees, and possessing all the most modern appliances for "washing" and "drying" the berries.

Having given, then, an idea of the enormous production of coffee in Guatemala, no excuse is needed for devoting this chapter to a description of the working of a finca, as the coffee estates in Central America are called.

The best departments for coffee-growing are, undoubtedly, those of the west and north-west, where the climatic conditions are well suited to the delicate task of transplanting the young trees, and of sowing the seeds, an operation usually accomplished during the rainy season. The ground must be very fertile, without being swampy, for no plant, except tobacco, impoverishes the soil so much as the coffee-tree.

The estates producing the best grade of berry, and the most abundant crops, are usually situated on the slopes of low hills.

Some of the largest fincas are found in the department of Quezaltenango, where the low foothills of the cordillera are covered with the rich green of coffee-trees, planted some ten feet apart, in long straight rows, which often extend as far as the eye can reach. In the centre of the estate, mostly on the crest of a hill, from which the whole plantation can be surveyed, is situated the estancia house, or residence of the estate-owner.

These houses are often very large, and handsomely furnished, in the most approved European style. Surrounding the dwelling are the small bungalows of the labourers, the drying floors, washing troughs, and packing and weighing barns.

The young trees are pruned, and the whole plantation is weeded every year; but from four to five years must elapse, after planting, before the young trees begin to yield anything like an abundant crop.

Some plantation-owners adopt the somewhat irrational method of growing other plants in the spaces 
between the coffee-trees, with the idea of using their land to the utmost possible extent, and of obtaining annual revenue from the soil, while the young coffec-trees are growing. This injurious practice not only greatly reduces the quality of the coffee, and production of the trees, but also impoverishes the land to such an extent that, within a comparatively short time, the whole plantation needs the assistance of artificial fertilisers to maintain the coffee crop at the requisite standard.

So prevalent is this practice, and to such an extent does it prevail, that on several small fincas, whose owners cannot stand the financial strain of waiting while the new coffee plantation grows, and prefer to occupy less ground and grow more-a shortsighted policy at the best of times-no less than three kinds of plants are growing on the same land.

Fincas worked on these lines may show, during the first few years, fairly large returns for the capital outlay, but the time soon comes-just as the coffee-trees should be yielding their best and most abundant crops-when the entire profits of the estate must be spent on artificial fertilisers, in order to support the coffee-trees alone. Once the land has been in this way impoverished, it takes many years of labour, at much expense, to render it again fertile, during which time the production of coffee is only about half what, with a little patience and foresight, it might otherwise have been.

The average yield per tree, after the fifth year, is approximately one pound of Liberian coffee, and about 9o per cent. per tree of the finer qualities.

After the coffee crop has been gathered, it is taken to the washing troughs, which are really shallow ponds, or channels of running water, having tiled floors and sides. The berries are then carefully washed, and afterwards spread out on drying floors, where the heat of the sun burns them to the required extent, after which they are passed through various processes, such as husking and 
polishing, and are then ready for packing in bags of sixty kilogrammes each, for export.

The keen competition in the European markets; caused by the enormous supply of coffee from Brazil, especially from the state of Sâo Paulo, which alone exports about $8,000,000$ bags a year, has caused the supply to exceed the demand. ${ }^{1}$ This greatly retards the growth of this industry in the republic of Guatemala, and also in the other countries of the American continent; but, notwithstanding the enormous increase in the production of coffee in Brazil, Guatemala has succeeded in not only holding her own against this powerful competitor, but also in gradually increasing her production ; and, what is more important, of finding a profitable market for it.

Although this is the case, many planters are turning their attention to the cultivation of cocoa and bananas, for which there is a great demand in the United States.

The average production of coffee is approximately 800,000 quintals, by far the larger proportion of which is exported to Germany. The reason for this is that many of the large fincas are owned by German individuals or companies, and consequently they send the bulk of their produce to the " fatherland."

Although coffee at the present time forms the principal article of export, before many years have passed, cocoa, hides, rubber, and fruit will be produced and exported in such quantities as easily to surpass the present staple product of the country.

${ }^{1}$ For a description of the industries, politics and places of the Brazils, or of the chief states of South America, see "The United States of Brazil" and "The Great States of South America," by the same author. 


\section{CHAPTER XV}

\section{THE NORTH AND WEST}

THE valley of Totonicapam, which is situated in the north-west of the country, lies about one hundred miles distant from Guatemala City. On all sides this broad fertile plain is hemmed in by lofty peaks and gigantic cliffs. The view from among the pines on the mountain slopes, over the sunlit sea of waving foliage, cultivated fields, and rolling prairies, is of that quiet, hot, misty beauty which, years afterwards, can readily be brought to mind, in the form of a mental picture of subdued lights and shades, when scenes of more striking grandeur have almost faded from memory. No discordant sound floats up from this enchanted valley; even the town, of the same name, lying but little below, seems wrapped in sleep, and nothing, save the light breeze of sunset rustling among the tall pines and spruce-trees breaks the lazy, slumberous silence.

Totonicapam, however, comprises not only the fertile plains just described, but also the rugged mountains on the lower slopes of which sheep find rich pastures.

Higher up, the bold contours are hid beneath the ridge of pines, reappearing again, only for a short space, before their blue outlines become lost in cloud.

Raised some 8000 feet above sea-level stands the city of Totonicapam, the capital of the department. Although one of the most important trade centres of the north-west, this, like the majority of Central American towns, can claim but few attractions other than its delightful surroundings. There is the 


\section{THE NORTH AND WEST}

inevitable plaza, surrounded by low whitewashed houses, and a promenade, prettily decorated with tropical trees and plants. It possesses one or two buildings of some pretensions, but by far the largest number are of the usual Spanish colonial style.

Notwithstanding the fact that Central Americancities, with but a few exceptions, lack the fine avenues, promenades, and architecture of European suburban towns, and are, in most cases, mere collections of sun-baked brick buildings painted white, they frequently possess a picturesque attractiveness of which the larger and better endowed towns of Europe are entirely devoid. The reasons for this soon become apparent. The blue sky, seldom clouded for many days in succession ; the balmy breezes, often heavy with the ever-varying odour of a hundred different varieties of tropical flowers ; the gaily dressed Indian girls, whose garments and shawls remind one of Jacob's coat of many colours, and whose long, shining black pigtails contrast strangely with the bright colours of their apparel ; the broad sombreros and multicoloured silk scarfs worn by the officials and plantationowners; the mantillas of the ladies, and the numerous characteristics of provincial and colonial Spain, are there set in a framework of the vivid green of tropic foliage.

The valley of Totonicapam, which is well cultivat $\in \mathrm{d}$, extends westwards, towards the sea, as far as Quezaltenango, one of the most important cities in the country, situated at the healthy altitude of 7400 feet above sealevel.

The most curious feature about Quezaltenango is its position on the heights of the cordillera, where the copious rainfall is divided in such a manner that one half finds its way to the rivers flowing across the country to the Atlantic, while the other goes to swell the torrents that, during the wet seasons, foam and splash down the steep western declivities of the mountains, cross the hot coast plains, and empty themselves into the Pacific. 
The rainfall, some twenty miles to the north of Quezaltenango, percolates down the northern slopes of the Sierra into Mexican territory, where it feeds the rivers flowing into the Gulf of Campêche.

Beyond stating that this city is one of the most important coffee centres of Guatemala, little more need be said, for it is certainly not famed for its architectural beauties, and its thoroughfares are thorough sells. Yet almost every month sees some improvement, and in a year or two Quezaltenango will have been entirely transformed. Modern buildings are gradually taking the place of the more primitive stucco dwellings, the streets are being paved, and there are already several pretty avenues.

A funicular railway between Guatemala City and Quezaltenango is projected. This line will have to traverse the heights of the cordillera for a distance of about one hundred and twenty miles. Should this scheme eventually mature, not only will this line prove one of the finest scenic railways in the world, but it will also stand for the genius by whose hand Quezaltenango, the highland capital, will rapidly and surely expand and develop, until it becomes a very much more important trade centre than it is to-day. Its chief recommendations, at present, are the soft mountain zephyrs, and the grand scenery with which it is encompassed.

Northern Guatemala comprises the following departments :-

Department

Quiché

Petén

Alta Verapaz

Baja Verapaz

Izabal
Approx. Population

Chief Town

\begin{aligned} \hline 93,000 & Santa Cruz de la Quiché \\ 7,000 & Flores \\ 100,000 & Coban \\ 55,000 & Salamá \\ 7,500 & Livingston \end{aligned}

The most developed and by far the most important of these is the department of Alta Verapaz, famous for the 


\section{THE NORTH AND WEST}

fine quality of the coffee it produces, and for the number of large fincas which cover almost the whole of its territory. Fruit also grows in abundance in the valleys, and is largely exported, by way of the Rio Polochic, to the Atlantic coast, whence it is shipped, mostly in Anglo-American steamers, to New Orleans.

Coban, the capital of Alta Verapaz, is decidedly the commercial and industrial centre of the whole northern territory. It has a population of over $\mathbf{2 2 , 0 0 0}$ and is elevated some 4000 feet above sea-level. Little can be said here about the city itself; for there are but few features worthy of special note, although it enjoys a considerable trade. The most imposing building is the Departmental Palace, and there are several quite respectable avenues and promenades. Other than the departmental capitals already enumerated, few towns are worthy of the name, many being merely collections of bungalows, or huts constructed of baked mud-bricks, and thatched with palms.

There are, however, one or two growing towns deserving of mention here, owing to the rapidity with which the surrounding fertile country is being brought under cultivation. These are : Primavera, a growing commercial and agricultural centre; Huehuetenango, capital of the department of the same name, situated in the extreme north-west of the state; Encuentros, Jacotenango, San Christobal, Sacapulas, and Panzos.

The river system of the north is fairly extensive, the principal fluvial highway being the Rio Polochic, which cuts across the north-eastern portion of the country from Port Livingston to Coban.

This fine river is navigable for small craft throughout almost its entire length. The Rio de las Salinas affords through communication with Mexico, and the two rivers Narajo and Samata, which rise in the mountains of Quezaltenango, flow to the Pacific coast.

The northern frontier of Guatemala, contiguous with 
British Honduras and the Mexican states of Yucatan and Campêche, is but little exploited, and in many parts is almost unexplored. It comprises immense tropical forests, which abound with rubber-bearing trees and valuable medicinal plants. These forests are often interspersed by plains covered with short scrub.

Standing back some few miles from the boundary of British Honduras is the Sierra de Santa Cruz, which forms a portion of the Mexican frontier. This chain of mountains stretches across the republic to the Sierra de Cuchumanes, and forms the strategical northern frontier of Guatemala. In the event of an invasion from this point of the compass, the Guatemalan troops would do well to hold this line of defence, instead of opposing en masse the hostile forces on the definite frontier lines.

Nothing more remains to be said about this portion of the country, for although the departments of Alta Verapaz and Baja Verapaz are among the richest coffeeproducing zones in the world, and although nearly the whole northern region is immensely rich in forests and land suitable for agriculture-possessing also, as it does in most parts, a fairly healthy climate-it is but little exploited, and, until the advent of the railway line, this large tract of country must develop but slowly. 



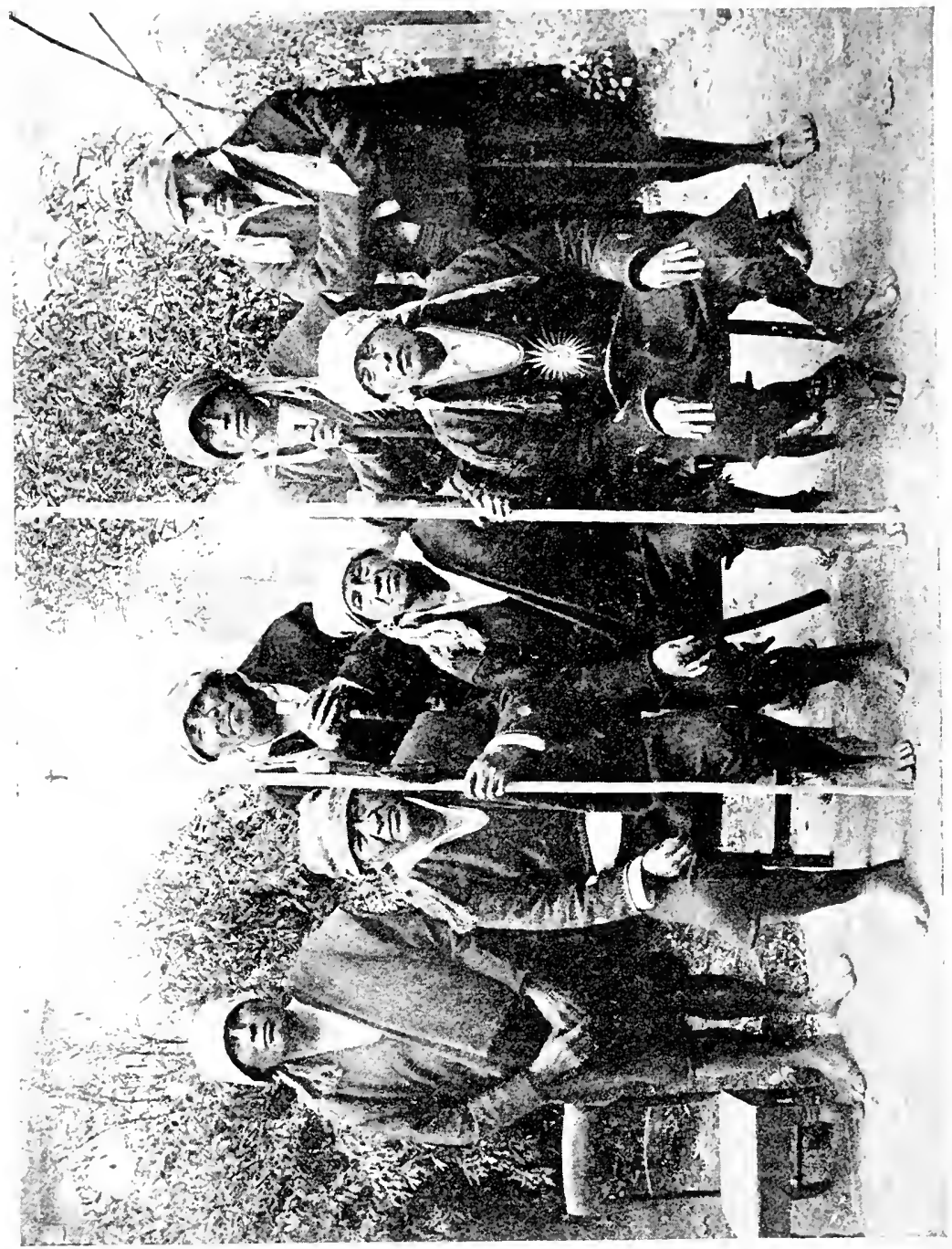

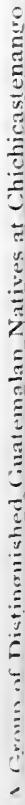




\section{CHAPTER XVI}

\section{FINANCE AND COMMERCE}

IF the division of space in this, or any other work of a similar character, were regulated by the national importance of the subject under discussion, then this chapter, which has for its object a survey of the financial and commercial status of Guatemala, would swell into a volume the length of which would certainly outstrip the patience of my readers.

What is of more material importance to any nation -when once it is assured, by an adequate armament, against foreign aggression-than the extent of its home and foreign trade? Commerce is the mainstay of empires and republics ; commerce is that for supremacy in which all peoples strive.

It may be that a time will come when the nations, adopting, by general consent, a different conception of life, will no longer gauge prosperity by standards so purely materialistic as those prevailing to-day. But that golden age of philosophy will not, for centuries yet, replace our age of hard coin. Towards commerce must men's activities, and those of their children turn. The great wars, even, of the near future, will be more and more promoted, or prevented, by commercial considerations. More and more will he who can pay the piper be in a position to call the tune. The great mass of civilised nations throughout the world are demanding easier material conditions of life, to be afforded them at the cost of the whole community, of the state. Only by a constant increase in the inter- 
change of world-products-which is commerce-can these results be brought about. The indebtedness of Guatemala has hitherto, undoubtedly, had a deterrent effect on its foreign commerce.

It must be remembered, however, by those who decry a country because of its present inability to meet the heavy demands incurred by foreign loans, contracted during periods of great financial strain and internal disorder, that there are but few young countries which have not, during some period of history, found themselves in a position of financial embarrassment ; and it should also be borne in mind that to allow differences of this character to affect disadvantageously the trade relations between two otherwise friendly peoples-however well one of these may be able to afford the small loss so entailed-is, to say the least of it, very impolitic. Other nations are incited thereby to redouble their efforts to gain commercial supremacy, the power of the country to demand a financial settlement is, at the same time, diminished, and a heavy loss is caused to the country under the financial obligation; her national resources being thereby weakened, and a satisfactory settlement made more difficult. Yet these remarks must not be taken as a defence of countries which fail to meet their financial obligations. No such plea, however well it might be framed, would avail before the great tribunal of international financial opinion.

Previous to the year 1904, Guatemala purchased more goods from the United Kingdom than from any other country, and the principal portion of the maritime commerce of the republic was carried under the Red Ensign.

In the year 1905, the United States, which, for several years previously, had been steadily gaining ground, succeeded in wresting from Great Britain the first place in Guatemala's commercial relations. During recent years Uncle Sam has more than doubled his commerce 


\section{FINANCE AND COMMERCE}

with Guatemala, and now imports into that country goods having an approximate average value of over $\$ 3,500,000$; and purchases goods having an annual value of nearly $\$ 3,000,000$. Germany has developed her trade in this zone, with even greater rapidity than the United States, and now occupies the place of second importance, exporting annually to Guatemala merchandise to the approximate value of $\$ 4,100,000$. England, third on the list of commercial relations, exports to Guatemala goods valued at about $\$ 2,000,000$, and imports from that country only just over $I, 000,000$, in approximate annual value.

The absence of any proportionate increase in AngloGuatemalan trade is partly accounted for by the strenuous endeavours made by the United States to increase her commercial prestige in Central and South America, by extensive advertising, by the investment of money in the various countries, and by the formation of intelligence bureaus, exhibitions, and commercial missions. The raison d'être of Germany's advance, in this respect, is clearly shown by the great excess of imports over exports. Large amounts of German capital are invested in coffee estates in Guatemala, with the natural result that the bulk of the product of these estates goes to the " fatherland," and nearly all the machinery and merchandise required by the estate-owners is purchased in that country.

However this may be, the fact remains that England has not increased her commerce with Guatemala to anything like the figures that other countries have succeeded in reaching. The principal reasons for this are : firstly, the ignorance of all but a few British manufacturers concerning the requirements of the inhabitants of Central America; and, secondly, want of enterprise, in not sending Spanish-speaking representatives, or appointing agents to obtain a market for their wares in this comparatively new field. 
A few points which must always be borne in mind by those endeavouring to extend their trade relations with Central Americans are: (I) that preference is shown by Guatemalans and Central Americans generally for Parisian style; (2) that prices, notwithstanding the difference in cost of production and transport, must compare favourably with those of similar goods from the United States, which gains by reason of her proximity, and with those of Germany, which gains so often now in cost of production, owing to increased output ; (3) merchants should first find out the slight differences which could be made in their standard goods, so that they may more strongly appeal to Central American taste; (4) that all printed matter should be in Spanish and English, as the fact of the two languages being shown will often induce Central Americans to keep such price-lists and prospectuses for their educational value, and consequently business may result in time to come. ${ }^{1}$

At present the imports consist mainly of machinery, dry goods, clothes, hats, ironware, wines and spirits, all forms of preserved food, medicines, pianos and musical instruments, porcelain, perfumes, typewriters, stationery and fancy goods. There is, however, an ever-increasing demand for the products of more advanced industries, such as electric appliances, the latest agricultural implements, motor cars, Spanish school-books, English grammar-books, cheap editions of English, French, and Spanish novels, small printing presses, well-made boots, clothes, and hats in the French style, advanced medical, chemical, and analytical apparatus, and modern machinery, which does not consume large quantities of fucl.

The exports consist almost entirely of agricultural

${ }^{1}$ I now have before me a Guatemalan newspaper in which an English lesson is a regular feature. 


\section{FINANCE AND COMMERCE}

and forestral products, such as coffee, leather, rubber, bananas, fruit of all kinds, sugar and timber.

The average annual value of imports and exports during the past five years is between five and six million dollars, and nine and ten million dollars (Guatemalan dollars gold), respectively, the principal portion of which have been carried in British or American vessels.

Guatemala enjoys considerable activity in agricultural and pastoral industries; but at present not a tithe of the fallow land available is under cultivation. In order better to realise the increase, in this respect, which is sure to take place during the coming decade, it is only necessary to glance at the table of acres cultivated with the staple products of the country, and to remember that Guatemala possesses 20,000 square miles of fertile soil.

Acres under Cultivation (approximate)

\begin{tabular}{|c|c|c|c|}
\hline Cattle-breeding estates & . & . & $892,500 \mathrm{a}$ \\
\hline Coffee & . & . & 830,000 \\
\hline Maize (Indian corn) & . & . & $24 \mathrm{I}, 500$ \\
\hline Sugar-cane . & . & . & 84,000 \\
\hline Banana plantations & - & . & 36,700 \\
\hline Beans & . & - & $2 \mathrm{I}, 000$ \\
\hline Cocoa & . & - & 15,750 \\
\hline Cereals (general) . & - & . & IO, 500 \\
\hline $\begin{array}{l}\text { Total area under culti } \\
\text { principal products }\end{array}$ & vation & & $2,131,950$ \\
\hline
\end{tabular}

The sugar industry is likely to increase greatly during the next few years, owing to the high quality of the cane. Cocoa and banana plantations are rapidly taking the place of virgin forests on the lowlands of the Atlantic and Pacific coasts ; and the many varieties of tropical fruits, which Guatemala produces in abundance, are admirably suited to preserving and drying, for exportation to Europe and America. 
Wheat and barley grow well in the cool atmosphere and fertile soil of the mountainous regions ; and cattlebreeding, on the plains of the south-west, forms a very profitable industry.

The dense forests, covering large areas in many parts of the country, contain thousands of rubber-bearing trees, and valuable dye-woods, the exploitation of which could be developed into important industries.

The State revenue is derived from the customs duties; liquor licences and monopolies; six per cent. on landed property; postal, telegraph, and telephone charges ; the sale and conveyance of real estate ; hereditaments and donations ; articles of food ; cattle, and salt, patents and concessions; tobaccos and wines; foreign companies; roads, exemption from military service; sale of fallow State lands; redemption of ground rents ; fines, and the export duties charged on rubber, coffee, maize, timber, lard in tins, swine, cattle, hides, and skins.

The average annual revenue and expenditure, taken over the last five years, is approximately 47 million and 55 million dollars, respectively. The Budget for the year I9I2-I3 shows that out of the total revenue of $37,500,000$ dollars $26,500,000$ is derived from the customs; and that the bulk of the expenditure - of $42,720,332$ dollars-is distributed as follows :-

Public Credit, 22,000,000 dollars.

Defence, 5,267,268 dollars.

Administration and Justice, 4,724, I70.

Public Instruction, 3,199,035 dollars.

Foreign Relations, 2,408,239 dollars.

Finance, 2,374,922 dollars.

Pensions, 5II,093 dollars.

In July I9II the Council of Foreign Bondholders (British) agreed to a proposal made by the Guatemalan Government for a settlement of the external debt, but 


\section{FINANCE AND COMMERCE 151}

owing to certain unforeseen political circumstances the default continued, and in I9I2 the British Government was asked to take action in the matter as no interest had been paid for fourteen years. A scheme for the early settlement of the outstanding foreign obligations has now been arrived at between the British, United States, and Guatemalan governments. The capital and interest of the four-per-cent external debt (I895) still unpaid amounts to considerably over $£ 2,200,000$.

There are seven banks in Guatemala, with a total capital of $\$ 18,426,000$.

Having now briefly reviewed the financial and commercial condition of the country, it remains only to point out that the balance of foreign trade is in favour of Guatemala, the average annual total value of imports and exports being, approximately, $\$ 5,000,000$ and $\$ 10,000,000$, respectively.

The exports have been rapidly increasing during the past few years, until they now show a difference, on the right side, of $\$ 5,000,000$. 


\section{CHAPTER XVII}

\section{MINERALS AND MINING}

CoRTES, the conquistador of Mexico, hearing of the fabulous wealth, in gold and silver ornaments, which adorned the temples and palaces of the natives of Guatemala, sent his famous lieutenant, Alvarado, to conquer the barbarous land and secure these riches, which vague rumour pictured as " altars of gold, and palaces lined with silver !"

Travellers' tales in the olden days, full as they mostly were of vivid imagination and strange fancy, possess even in these commercial times a fascination no less potent than in the age when Sir Francis Drake, John Hawkins, and the like, bold buccaneers, sailed for the Spanish main.

Financiers, merchants, and adventurers of to-day watch carefully the initial development of the mineral resources of every country. The finding of a few nuggets or precious stones is the signal for the rush. An intense desire to get rich quickly, the love of excitement, the splendid visions of an after-life of ease and laissez-faire, carry plucky miners into the most forsaken and pestilential corners of the earth, and enable them to overcome difficulties otherwise insurmountable. It was this love of adventure, and greed of gold, that impelled the buccaneers in the days of Good Queen Bess to seek out the Spanish treasure-ships; it was the same power that induced the rush to Klondyke, to the goldfields of Australia, and of the Transvaal.

The first record of mining operations being carried on 
by Englishmen in Guatemala occurs in the year 1620 , when a party of London merchants commenced the exploitation of a mine in the region of Las Vacas. Since that time several thousand claims have been granted and many rich properties opencd up.

Although numerous concessions have been bestowed, upon most liberal terms, by the Government, and many promising mining undertakings have been started, no organised and determined effort to exploit the rich veins of gold, silver, copper, coal, iron, and zinc, have, until recently, been made. The exact reasons for this are not easy to assign. Until the promulgation of the new, and exceptionally generous, mining code by the present Administrative, it was generally believed that the vagueness and uncertainty of the laws relating to mining did much to retard the natural growth of this industry. This doubtless partly accounts for the present undeveloped state of the mineral resources of the country ; but lack of capital and want of enterprise have been the chief causes of failure. It must also be remembered that financiers and mining magnates have been closely engaged for many years, in exploiting, first the goldfields of Australia, then, later, those of South Africa and Klondyke; while recently Siberia has sprung into prominence as a land of great mineral wealth. Little necessity has existed, therefore, for the development of new zones.

Apparent lack of enterprise, on the part of Britishers, in searching diligently for new mineral zones of development, has lost to the empire the "lion's share" of mining rights in the republic of Guatemala.

During IgII numerous articles appeared in the American and European Press stating that reliable reports had been received, to the effect that Guatemala had been sold en bloc to a company of American millionaire financiers. This rumour originated, as may be supposed, in the United States, and was received with 
credulity by several European newspapers of importance, although, in fairness, it must be said that, so far as the London Press was concerned, some doubt was thrown on the veracity of the report. But, apart from its political significance, this was not altogether a case of smoke without a fire. The origin of the rumour may be told in a few words. A party of Americans had been prospecting and surveying in Guatemala for some considerable time, and, after prolonged endeavours, had concluded an agreement with the Guatemalan Government, by which-on conditions necessitating the expenditure of considerable sums of money in the republic, and the successful carrying-out of extensive schemes-they obtained what are practically sole mining rights throughout the state. ${ }^{1}$

To say that Guatemala was ever likely to become essentially a mining country would be to state what is highly improbable; but that several regions are undoubtedly very rich in precious metals is an undeniable fact, that, before many years, will have been fully proved.

There are three clearly defined mineral zones where the outcroppings of gold, silver, and copper prove the richness of the veins beneath the surface. The region most abundant in gold-bearing rock is that of Las Vacas, although in the Sierra de las Minas, which is situated in the extreme north-east of the country, rich veins of gold have been traced.

In the rivers Polochic and Motagua, placer-mining is now being carried on with considerable success, as is also the case in several of the streams flowing towards the Pacific coast. Deposits of silver, copper, and lead have been recently discovered in the belt of territory between Zacapa and the frontier of San Salvador ;

${ }^{2}$ Exact terms of concession not to hand, but probably a royalty will have to be paid on the ore extracted, and a time limit will be stated in the agreement. 
and the ancient workings of silver mines may be seen along the slopes of the cordillera, on the Pacific coast. Coal has been discovered on the Atlantic scaboard, near Santa Tomás, and also exists at several points farther inland. Sulphur and lead are produced in sufficient quantities to supply the home demand.

It is not possible to give much more information on this subject, as but few of the vast mountainous regions of the state have been systematically examined by competent prospectors. There are many gullies and passes that have scarcely been explored by white men, and cañons innumerable, in which the ring of the miner's pick has never been heard. The massive gold and silver ornaments, known to have adorned the Quiché temples and palaces, prove conclusively that an eldorado must have existed, in one or more regions of the country. This being the case, there is but little doubt that, when prospectors turn their attention to exploring in Guatemala, as they have done, with so much success, in the adjoining republic of Mexico, many new and valuable mines will be opened up.

An excellent example of the profitable results obtained, when mining enterprises in Guatemala are carried out by experienced engineers, is afforded by the San Pantaleon property, which has been worked since I866, and belongs to an English company. According to reliable estimates, this mine produced, during the first twenty years, over 40,000,000 gold dollars. Among the many rich mines that have yielded, at various times, enormous amounts of gold and silver ore, may be mentioned those of Las Vacas, La Liberdad, Bananche, and Lomby La Costa del Oro, which has been worked since its discovery, in the year I6go. The low price to which silver fell, some years ago, caused many of these mines to be abandoned, and, through lack of capital and means of transport, they have never been reopened. Others are still being 
worked with more or less profitable results, although, in one or two instances, trouble has been caused by the rise of water in the deep shafts.

The introduction of modern machinery, and the extension of the railway system, are the two potent factors that will determine the rate of development of the mineral resources of Guatemala. ${ }^{1}$

${ }^{1}$ M. Désiré Pector (Consul-General in France of Honduras and Nicaragua), author of "Les Richesses de l'Amérique Centrale" (Guatemala, Honduras, Salvador, Nicaragua, Costa Rica), says of the mining possibilities :

"In spite of the invasion by foreign miners, Yankees for the most part, of the mineral region of Central America, this rich region at present exports little more than 25,000,000 francs worth $(£ \mathrm{I}, 000,000)$; this sum ought to be more than doubled"; a fact which the author rightly attributes, among other causes, to lack of capital for exploitation, to insufficiency of technical knowledge, of workmen, and of means of communication. He says, further, that Europeans generally, with the exception of a few English and Germans, are absolutely ignorant of the inexhaustible resources of Central American soil, which they leave to the profit of North Americans. 


\section{CHAPTER XVIII}

\section{OFF THE BEATEN TRACK}

A RUSH across country rich in green, over mountains clothed in cloud and helmeted with snow, then a wild, headlong plunge into dense tropical forests - a kaleidoscopic picture of vivid light and colour, truly magnificent, but unreal and unlasting-such is too often the modern traveller's only view of Guatemala, and of many other countries not fortunate enough to possess a London or a Paris to break the "hustler's" flight over the parallel lines of the railway. Yet one may be fairly sure that, for every fleeting scene of beauty obtained through the windows of a railway carriage, within the limited horizon of the " made road," there are countless views of far surpassing grandeur, when off the beaten track.

Travelling in the interior of Gautemala is accomplished by many more ways than one. Between several of the important cities on the tableland, such as Quczaltenango and Guatemala City, there are regular coach services. These mule-power vehicles, with their swarthy drivers and native postboys, bring to mind scenes of the old coaching days in the Wild West ; each crack of the driver's long hide whip suggests an Indian attack. The mountain roads that, in the far-distant regions, degenerate into mere beaten tracks, over which these somewhat ramshackle vehicles are pulled by the straining mule-teams, should prove excellent cures for weak nerves, or that most distressing malady, lassé de vie; for, in the highlands, 
they frequently wind down the side of mountains several thousand feet high, with a wall of volcanic rock on one side, and a dizzy precipice within a few feet of the rapidly turning off-side wheels. The racing teams are goaded on by the sharp reports of the ominous lash, which, however, seldom descends on to the backs of these occasionally stubborn animals which drag the coach, swaying and jolting over the broken roads. The passenger, as he is bumped ruthlessly backwards and forwards, then up and down, realises the origin of that anatomical impossibility, so frequently referred to in flamboyant books of adventure: "His heart leaped into his mouth." The experience of the author is, however, that such "vibrators" usually cause a certain displacement, not of the heart, but of the liver.

Although such experiences are inevitable on some of the less frequented coach-roads, it must not be supposed that there are no exceptions to this rule; for the main highways of Guatemala are very fair specimens of country roads, and on many of these it would be quite possible either to motor or cycle in comfort, provided, of course, that petrol was forthcoming at the necessary points, which within a year or so will doubtless be the case. Even now there are several fine cars in Guatemala City, and every month sees an increase in their number.

So much for the roads. And now what of the inns wherein the traveller shall find rest for his weary bones? Well, frankly, in Guatemala, off the beaten track, you will find no Ritz. But those who are sensible enough to travel in that country will not ask for one. Moreover, the lamentable truth is, that the hotels and inns of Guatemala need not, generally speaking, be a source of great pride to their proprietors ; and, in the country places especially, the traveller must not be exigeant, either as regards cleanliness or cuisine. Indeed, there is still many a hostelry of Guatemala to whose bill of 


\section{OFF THE BEATEN TRACK}

fare may be still applied the famous description of Jose Milla, the novelist of the country, in his famous historical romance, "El Visitador" : "Here we have one day, tortillas, eggs, and frigoles; the next day, eggs, frigoles, and tortillas; the third day, frigoles, tortillas, and eggs; and on the day following, again tortillas, eggs, and frigoles. It is thus we change in order that our guests may always have a variety of dishes, and so be satisfied." For three hundred years, says Mr Castle, things in that inn have not changed. Yet, after all, in the average English hotel, are you not still expected to ring the changes between " eggs and bacon" and "bacon and eggs." If a duck waddles under your chair at meal-times, or the hens nest on an old saucepan on the shelf, if skinny cats and mangy dogs do sometimes invade your privacy, remember that Guatemala is a land of the future-and forgive.

Yet the picture is not all dark. Often the patio, or central courtyard, of a Gautemalan hotel is a charming spot, sheltered from the wind, and all ablaze with roses, marguerites and other flowers, according to the season and the climate, which, of course, varies with the elevation. Then, while sitting at your ease, you may summon to you the maitre d'hotel, and unfold to him any grievance you may have. $\mathrm{He}$ will usually listen with patience, and promise amendment with good humour-indeed, the same may be said of the menials-but to get him to act is a different matter. It is "to-morrow, and to-morrow, and tomorrow." Guatemala, in both senses of the word, is a land of to-morrow. It creeps on in its petty pace from day to day. Should you insist upon a roast chicken being served to you at once, you will be met with the phrase " no hay" ("there are none"), though the yard be vocal with clucking-and so with everything else in the menu. What a paradise will Guatemala be when to-day begins to assert its claims! 
And, now that I am grumbling, let me add that the native Guatemalan bed is not a wholly satisfactory production. It is, in fact, no more than a sort of hammock of tightly stretched canvas without a mattress, fastened to folding sticks. The pillow is small, and the speckled and mottled sheets are ventilated after a peculiar, native manner. Mr Castle says graphically: 'I have tossed on this 'drum,' racked with fever, listening day and night to the discords of a neighbouring gramophone, hoarsely venting grand opera and negro minstrelsy, my temperature at one hundred and seven, and with two hundred grains of quinine scattered through my anatomy. I wish my worst enemy in no more hideous experience."

But our experience to-night will be a better one. Have we not our tent and our sleeping bags? Come out with me, while supper is preparing, and let us put Nature to bed.

A sound, as of approaching wheels, breaks the stillness; grows louder. We pause to watch the procession. The oxen drawing the wooden carts, solely by the yoke attached to their horns, pass by, mild-eyed, with heads submissively bent. Beside them trudges a darkskinned native with a broad-brimmed hat. He grasps a long stick, and with that implement, an occasional sibilant hiss, and an unfailing torrent of appalling blasphemy, he achieves remarkable success as a driver. Strange beings, these Indians, and worthy of a small chapter to themselves.

Let us walk down the track awhile, and then skirt the edge of the forest. Here is a native hut, with one room in it, twenty feet square, where lie down at night, perhaps, some ten human beings, with twelve children, three pigs, and insects innumerable. Here is the edge of the twilight forest, already haunted by the mystery of the coming night.

The saucy blue jays will cease chattering before the 


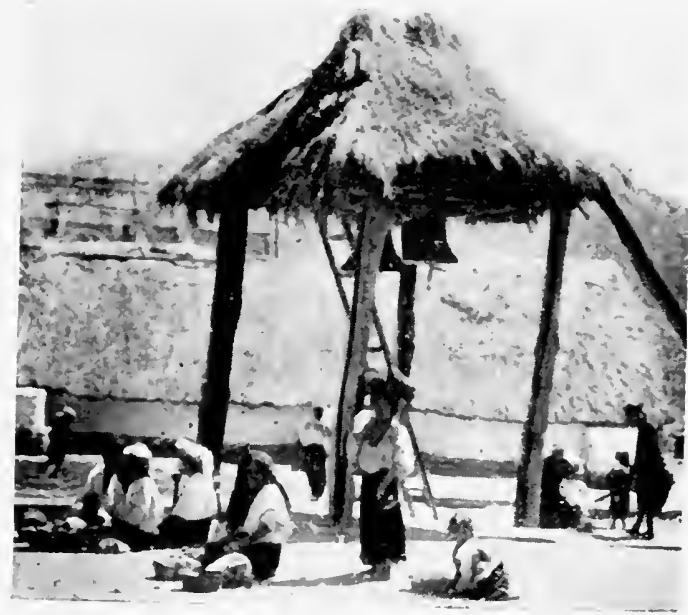

A Village Scene in the Interior of Guatemala

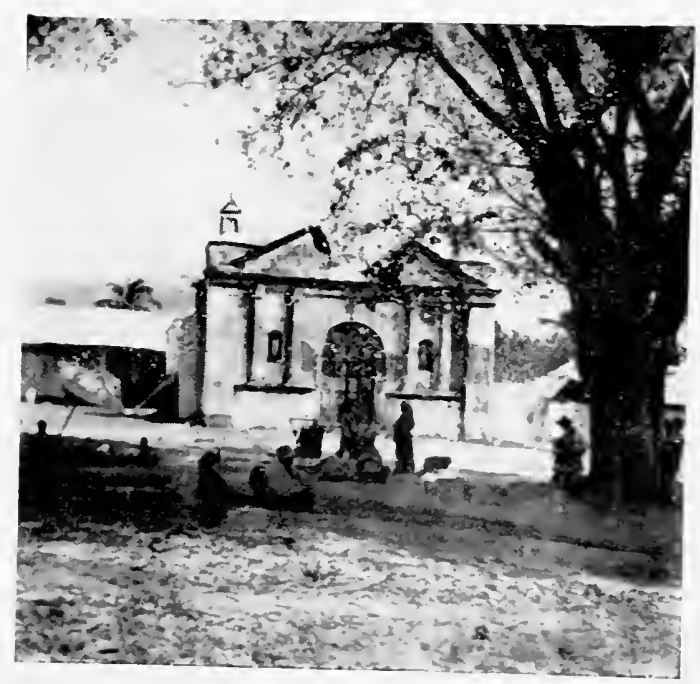

The old Spanish Church, Palmar, Guatemala 

sun goes down, but with the rising of the moon you will hear the cry of the whip-poor-will and the chirping of the crickets, the bats will fly past you, the fireflies will make thcir torchlight festival in the branches, and by the edge of the pool the frogs will be holding debate, "croak! croak! croak!"

Words fail me when I attempt to describe the wonders of a Guatemalan forest. Only those who know the tropics know the magic of the scene, know the sensations of admiration, of wonder, of awe even, that fill the mind as one gazes up into that mysterious, majestic world of a myriad tangled greens; trunk, bough, and foliage of every quality and kind, from the mighty timber of the mahogany and ceiba trees, to the bamboos, the blossoming reeds, to the fronded palm-trees, the climbing growths that, vinelike, hang in festoons fair as those with which the Greeks of old adorned their holy temples. For this is Nature's own temple, not a stone of which she has left unbeautified. The dead logs, even, are shrouded in moss, and the forest glades are splashed and dappled with many-coloured orchids.

Stop and listen to the forest speech-to Nature's wild orchestra, whose harmonies awake with the sun - the buzz of countless insects, the warble of a million birds, the chatter of the white-faced monkeys, the screech of a flock of parrots shrilling harshly from the green wonderland above. Brilliant is the colouring of bird and butterfly-more varied, more lovely, perhaps, than in any other country of the world-the toucan, the kingfisher, the macaw.

Gently the zephyrs sway in sinuous motion the graceful coroza palms, and stir their lovely leaves; the forest answers the gurgling note of the orpendula, the screams of brilliant macaws, the hoarse roar of the monos. At one's feet fall choice blooms, shaken by a perfumed breeze from invisible tree-tops. Even at night the forest is not silent, for then you may 
hear from the upper darkness the cry of the howling monkey.

One peculiar characteristic of a tropical forest in Guatemala is the extraordinary variety of the trees. There are oaks, pines, cedars, and mahogany in abundance, yet you cannot decide that " this is a cedar forest "-or that it is given over principally to any other growth. Every growth is prolific. The grandest of all, perhaps, are the great ceibas, from whose huge trunks spring buttresses, like those that support a great Gothic nave. And vast is the congregation that this leafy cathedral could shelter.

I shall have little to say in this book concerning the fauna of Guatemalan jungles. They include jaguar, tapirs, ant-bear, deer, alligators, serpents of various kinds, iguanas, great spiders, scorpions, and butterflies of innumerable varieties. These last are one of Guatemala's most characteristic features. The native will tell you that to attempt to catch these butterflies is " mala por los ojos," " bad for the eyes "- -a superstition that doubtless owes its origin to the ill effects that may often result from an attempt to follow in the glare of tropical sunlight the zigzag flittings of those brilliant wings.

The bats of Guatemalan forests, to the outward eye bright, attractive little creatures about the size of sparrows, are evil and bloodthirsty within. They are vampires that fasten in the night upon unoffending cattle, which you will find, in the morning, bleeding from a wound in the shoulder. Many are the sleeping travellers who have been awakened by the brush of vampire wings upon their faces; sometimes even, if the feet were uncovered, to find that cattle were not the only animals who paid tribute of their blood.

There are many iguanas, too, that lie, not easily distinguishable, upon the branches above the water, small, alligator-like animals, with a toad's mouth, 
glittering green eyes, a row of spines down the back and a long tail-beasts ill to look upon, but amiable withal, gentle, and so easily tamed that they are the friends of many an Indian woman. They lay good eggs, too, all yolk and very delicious. Nor is the iguana to be wholly despised, even after death. Kings' sisters have tasted of them. Listen to this: "These serpentes are lyke unto crocodiles, saving in bigness; they call them Guanas. Unto that day none of oure men durste adventure to taste of them, by reason of theyre horrible deformitie and lothsomnes. Yet the Adelantado being entysed by the pleasantness of the king's sister, Anaceona, determined to taste the serpentes. But when he felt the flesh thereof to be so delycate to his tongue, he fel to amayne without a feare. The which thyng his companions perceiving, was not behynd hym in greedyness; insomuch that they now had none other talk than of the swectnesse of these serpentes, which they affirm to be of more pleasant taste than either our phesantes or partriches." 1

Alligators, of course, frequent the waters in thousands. All I shall say about them is that the Indians in the district of Zarazoga have such a liking for dried alligator meat, as lenten fare, that the vendors of that highly perfumed delicacy have to be locked up in the "carcel " for protection, and sell the meat through the prison bars.

One cannot leave the subject of Guatemalan live stock without one word upon not the least interesting of its inhabitants - the ants.

The march of an army through the house is a common experience, somewhat terrifying to those unaccustomed to it, though not unwelcome to the Indians, as it rids them, for a time, of centipedes, scorpions, and other noxious beasts. Indeed, through all insect life that

1 "Peter Martyr," Eden's English translation (quoted Brigham's "Guatemala," p. 48). 
finds itself in the path of the army, consternation is spread. Large beetles and cockroaches, hearing the roof crackling beneatlı the feet of the enemy, withdraw to the last leaf of the thatch, and there, paralysed with fear, with antennæ stiff and eyes dreadfully glaring, await death.

These, of course, are the marching or " army ants," of which Mr Stephens gives such fascinating accounts in his "Naturalist in Nicaragua," the book that gave Darwin so much pleasure. His attention was generally drawn to their approach by the twittering of small birds that follow the ants in the woods. "On approaching to ascertain the cause of this disturbance, a dense body of the ants, three or four yards wide, and so numerous as to blacken the ground, would be seen moving rapidly in one direction, examining every cranny and underneath every fallen leaf. On the flanks, and in advance of the main body, smaller columns would be pushed out. These smaller columns would generally first flush the cockroaches, grasshoppers and spiders. The pursued insects would rapidly make off, but many in their confusion and terror would bound right into the midst of its enemies, would give vigorous leaps with perhaps two or three of the ants clinging to its legs. Then it would stop a moment to rest and that moment would be fatal, for the tiny foes would swarm over the prey and after a few more uneffectual struggles it would succumb to its fate, and soon be bitten to pieces and carried off to the rear." There is another well-known variety.

" The first acquaintance a stranger generally makes with them is on encountering their paths on the outskirts of the forest crowded with the ants, one lot carrying off the pieces of leaves, each piece about the size of a sixpence, and held up vertically between the jaws of the ant; another lot hurrying along in an opposite direction empty-handed, but eager to get 


\section{OFF THE BEATEN TRACK}

loaded with their leafy burdens. If he follows this last division it will lead liim to some young trees, or shrubs, up which the ants mount; and then each one stationing itself on the edge of a leaf commences to make a circular cut, with its scissor-like jaws, from the edge, its hinder feet being the centre on which it turns. When the piece is nearly cut off, it is still stationed upon it, and it looks as though it would fall to the ground with it; but on being finally detached, the ant is generally found to have hold of the leaf with one foot, and soon righting itself, and arranging its burden to its satisfaction, it sets off at once on its return. Following it again, it is seen to join a throng of others each laden like itself, and without a moment's delay it hurries along the well-worn path. As it proceeds other paths, each thronged with busy workers, come in from the sides, until the main road often gets to be seven or eight inches broad and more thronged than the streets of the City of London." 1

Before describing some further scenes in the more remote regions, it may be as well to remark here that European or American travellers, who contemplate undertaking journeys in the interior of Guatemala, need not indulge in the expensive and very doubtful luxury of an explorer's outfit. Clothes like those worn in the cities of South Europe during the summer should be taken, with the addition of a thick overcoat, and wraps for use at night, when the cool breezes of sunset, in the highlands, make warm clothing necessary. For travelling in the interior, khaki drill, or grey Canadian cloth, is the most suitable material, and in Guatemala City evening dress, although not de rigueur, is general. On public occasions in the capital morning dress is usually worn. Before leaving Guatemala City en route for the more distant parts, or on a journey of exploration, deliciously uncertain as to where, or in 
what time, it will end, I advise you to supplement the passport, which, by the way, is not actually necessary, with a letter from his Excellency the President, or from one of his ministers. This can usually be arranged through the diplomatic channels, and often proves of great value in obtaining information and assistance from the various Jefes Politico, or local magistrates.

Travelling in Guatemala, away from the railway lines or coach-roads, is most frequently accomplished on mules or horses; the former animals being generally preferred, as they are the more sure-footed in the mountainous regions, and are more hardy and reliable than horses.

One of the most enjoyable features of travel in the highlands is the first stage, in those bright and glorious hours between sunrise and about eleven o'clock. After that time the increasing power of the sun begins to make exercise somewhat tiring, though anyone accustomed to travel in semi-tropical climates will find no difficulty in journeying continuously throughout the whole day.

The scenery in the mountains on the Pacific coastthe most northern chain of the great Andes, which rise to the snows in South America-is of a peculiarly fascinating description, grand in some places, yet sombre, almost beyond description; and in others, such as around those most beautiful lakes, Atitlan and Amatitlan, picturesque and gay with prolific growth. The views hereabouts are much enhanced by the glimpses obtained through the forests, which clothe the encircling hills almost to their summits, of the shining surface of the lake, nestling in a pit of green foliage, many hundred feet below. Descending the northern slopes of the mountains, on to the forestcovered plains of the Mexican frontier, the changing climate has a comparatively sudden and marked effect upon the vegetation. The descent being somewhat 
rapid, especially near the coast, a few hours of scrambling, with laden mules, down the rugged and broken mountain paths, precedes the plunge into the dense forest growth of the tropics. Damp, spongy ground covered with moist, exuberant vegetation, intersected in places by bogs and swamps, takes the place of the dry, rocky, though broken, and often difficult, bridlepaths of the highlands.

Although the forest region of Northern Guatemala is very damp, it is exceedingly fertile, and not altogether unhealthy. Large tracts of land have now been cleared, and are occupied by immense cocoa plantations, which may be numbered among the most promising and profitable undertakings in the country.

On these estates the cost of growing and shipping cocoa is estimated to be about twenty-five shillings per ton. The product is of the fine quality known as Soconusco, and often realises, in the markets of Europe and America, a very high price. The wide margin of profit is, without doubt, the cause of the rapid growth of cocoa cultivation on the plains of Guatemala.

Thousands of acres of forest-covered land are annually being cleared, to make room for new cocoa or banana estates, and the comparatively cheap native labour acts as a stimulant to these rapidly growing industries, which, before many years have passed, will have attained the same degree of importance, and high standard of production, as that now held by coffee.

When exploring in Guatemala, it is impossible not to be attracted by the large number of powerful waterfalls which never cease to expend their mighty energies in uselessly pounding the surrounding rocks. Their dull roar may be interpreted as a ceaseless remonstrance against the apathy of the populous centres-some of them almost within earshot-in not 
utilising these great natural powers. In contrast to this lack of enterprise-or deficiency of capital, shall we say - on the part of a nation struggling towards development and the attainment of a high degree of exploitation, we may note the keen competition for hydraulic power, when in close proximity to forests, to the sea, or to towns, now taking place in Norway, the United States, Canada, and even in that great country of the future-British Africa. 


\section{CHAPTER XIX}

\section{THE NATIVE POPULATION}

Without attempting the difficult task of giving a minute study of the ethnological conditions of Guatemala, or of the history of the Quichés, Toltecs, Caribs, or, in fact, of any of the sixteen native races who, at different periods before the dawn of modern history, have inhabited the land of the sacred quetzal, a few remarks upon the dress and customs of the now docile and half-educated descendants of those brave, though barbarous, savages is essential to a clear understanding of the Guatemala of to-day.

Although the natives, or descendants of the aborigines, form by far the largest portion of the population, and are much en evidence in all the cities of the country, it is only in the more remote regions that their ways and customs can be accurately studied. Travellers who have had the good fortune to visit those beautiful islands, the British West Indies, will readily call to mind the queer figures often presented by the Caribs, when dressed in their "Sunday best." Such is the case on the mainland, where these docile and somewhat childish people have now become more than half civilised, and, like the Indian " baboo," have in consequence discarded the dress (what there was of it) and customs of their forefathers, adopting, instead, white dresses, black suits, sombreros, and other items of semi-civilised garb, as well as the manners, in a crude form, of the conquering white man.

But in the interior of the country, if the rural dis- 
tricts of this comparatively small and partly developed state can so be called-away from that great agent of progress and civilisation, the railway-the Guatemalan Indians still retain some of the picturesque and less barbarous customs of the past. A characteristic feature is their love of black clothes, tending to increase rather than to relieve the usually doleful expression of their countenances-a trait which, however, must not be taken as the badge of a dejected or oppressed race. On the contrary, they are a contented and very happy people ; yet it must certainly be admitted that, in many cases, their looks belie them.

The better-class native wears black clothes when in the cities, and also on public holidays, but the working garb of the majority is simplicity itself, consisting usually of a loose jacket, and a pair of dirty, white trousers, frequently cut off short at the knees, a broadbrimmed straw hat, for protection against the sun when working in the plantations, and a large coloured shawl of native manufacture, wherewith to defy the cool breezes which usually prevail for some time after sunset. In contrast to this peculiar, yet simple, taste of the men, nothing pleases the native women, especially the young girls, so much as vividly bright colours. Their dress varies according to the importance of the occasion. When Guatemala holds carnival, they may be seen in loose blouses or short jackets gaily embroidered, with a peculiar cap, or small mantilla of white or coloured cotton. Necklaces and large silver rings are also worn by " La Belleza India."

Many of the Indians wear a quite negligible quantity of raiment $-\mathrm{a}$ breech-cloth for the men, and a short skirt for the women being sometimes the whole attire; but they are not now permitted to enter the towns without a certain minimum of clothing. That explains the not unusual sight of a native, by the roadside, 


\section{THE NATIVE POPULATION}

thrusting his skinny, dark legs into light trousers, while his wife veils her Venus limbs beneath a scarlet skirt. The toilet accomplished, they take up their burdens, whose bulk would appal two oxen, and, splendidly upright-de te fabula, O ladies of Europe !they trudge off to the market.

The children often are only very poorly dressed, and in some districts scarcely dressed at all, wearing simply a short skirt or a loose garment, not unlike an old dressing-gown, made either of coarse native cloth, or of cheap, imported material. In the cities, however, they look much more respectable, being attired in cotton suits, and in some cases in the most approved civilised fashion.

Many of the well-to-do natives in the towns, and also not a few in the country districts, also wear modern clothes, and the clean, white muslin frocks of their children form quite a pleasing sight during the scholastic and religious fêtes, and when they are attending school.

Concerning the habits and customs of these people, little generalising can be indulged in, for in some cases they are scrupulously clean, quiet, and honest, and, in others, exceptionally dirty, drunken, and dishonest, though this latter type are certainly in the minority. Generally speaking, they are religious, and superstitious, delighting in the mystic rites and ceremonies of the Catholic Church; they are, on the whole, and when sober, docile and obedient to a marked degree.

The worst and most common vice among the Indians is that of drunkenness, a failing which, no doubt, will tend to diminish when the Government abandon their present monopoly upon " white eye," the native spirita kind of gin-which is always the cause of the intoxication. Some years back one tribe of Indians purchased from the Government immunity from the sale of the liquor within their territory, but the transaction led 
only to smuggling and worse drinking, just as it does to-day in the prohibition states of America.

In the minds of the Indians-in the mind, probably, of that very Indian whom you may see there, with two pigs on his back, knecling beside the handsome Spanish lady in the aisle of the church-the superstitions of an immemorial past, and the dogmas of an accepted creed, are strangely interwoven. Still, in the remote parts, the Indian, nominally Catholic, will creep away, with awe in his soul, to consult the old, wrinkled wizard, whose rites of mingled fire and devil worship still exercise an irresistible charm over the untutored mind. Then, with words of magic in his ears, he will return to the church, and there, before the Christian altar, will burn the same incense that his ancestors hundreds of years ago prepared for their idol worship. $\mathrm{He}$ would make the best of both religions. It were safer so. Can the average Englishman afford to throw a stone at him?

Superstitious and ignorant! Mr Maudslay once asked a Cajabon Indian to take service with him. The man refused point-blank. "Why not?" said the traveller. The native replied: "Los Ingleses comen gente" ("The English are cannibals"). I agree with that author that this is probably a survival of the stories told to the Indians by the Spanish priests and officials, in the days of the buccaneers, when English smugglers were a great annoyance to the Spanish authorities.

Even the camera,to many of the Indians in the remote parts, is a fearsome thing, an instrument of " brujeria," or witchcraft, in which, in common with the majority of savages, they implicitly believe. Just as a Papuan native is convinced that the witch of his village can certainly, at her will, implant a fatal frying-pan in his stomach, so some of the Guatemalan Indians believe that the camera, or the man behind it, can fire into his stomach a pailful of snakes. And that is not 
worth the victim's while-not even for a "medio" apiece.

The religion of the Indian is, and will be for generations to come, inextricably mixed with the traditional beliefs of his primitive ancestors. Drawn by his love of show and ritual, he has accepted nominally the dogma of the Roman Catholic Church; yet it is often a matter of doubt, even to priests who have lived among them for many years, whether the Indians really understand the principles of the Christian faith. We venture to think that they do not; but they are by nature so fond of ceremony that the services of the Church of Rome are naturally congenial to them, and have now become a part of their daily life.

I cannot possibly give a better idea of the native attitude towards the problems of the universe, than by quoting the following Quiché prayer, from Mr Brigham's very interesting book:-

"O Jesus Christ, my God, thou God the son with the Father and the Holy Spirit art but one God. To-day on this day, at this hour, on this day of Tijax, I invoke the holy spirits who attend the dawn and the last glimmerings of day. With the holy spirits I pray to thee, O Chief of the Genii who dwell in this mountain of Sija-Raxquin! Come blessed spirits of Juan Vachiac, of D. Domingo Vachiac of Juan Ixquiaptop; blessed spirits of Francisco Ecoquij, of Diego Soom, of Juan Tay, of Alonso Tzep, holy spirits I repeat, of Diego Tziquin and Don Pedro Noj; you, $O$ priests, to whom all things are open, and thou Chief of the Genii ; yc gods of the mountain, Gods of the plain, Don Purupato Martin, come accept the incense, accept now this candle! Come also mother mine, Holy Mary and thou my Lord of Esquipulas, the Lord of Capetagua . . Captain Santiago Saint Christopher ... thou Lord and King Pascual, be priest here. And thou frost, thou God of the plain, 
thou God Quiacbasalup, thou Lord of Retal-eulcu. . . . I make mysclf compadre and comadre there the priest is speaking for the petitioner], I who pray, I am the witness and the brother of this man who makes himself your son, of this man who prays. O blessed spirits, suffer.no evil to come to him, nor let him be unhappy! I the one who speak, I the priest, I who burn this incense, I who pray for him, I who take him under my protection, I beseech you that he may easily find his food. Do thou then God, send him his money; do not allow him to get sick with fever, let him not become paralytic, let him not be choked with cough, let him not be bitten by a serpent, let him not be swollen with wind nor asthmatic, let him not become mad, nor be bitten by a dog, let him not perish by a thunderbolt, suffer him not to perish by rum, nor die by sword or stave, neither let an eagle snatch him away; assist him $O$ clouds, assist him $O$ lightnings ! assist him $O$ thunderclap! aid him St Peter, aid him St Paul, aid him thou Eternal Father! I then who have spoken for him thus far, I pray that sickness may come upon his opponents, grant that when his enemies go forth from his house he may encounter sickness, grant likewise that wherever he may please to go, there may he meet with difficulties. Do your duty against enemies, wherever they may be; do it as I pray you, blessed spirits! God be with you! God the Father! God the Son, God the Holy Ghost! So be it! Amen, Jesus!"

From which effusion the reader will perceive that native Christianity is apt to degenerate into the pure nature-worship of the savage, Christianised only to the extent of a few orthodox phrases.

One of the most interesting sights in a Guatemalan town, such as Quezaltenango, for instance, is a religious procession. Between files of kneeling Indians and spectators with bowed heads, pass the women bearing 


\section{THE NATIVE POPULATION}

splendid banners of silk and satin, whereon are written the names of the saints. Many an image, too, is to be seen, its strange figure rising and falling to the steps of the bearers, among the glittering candles that twinkle in many a hand. After the Christ follows a brass band discoursing music that, to English ears, sounds sometimes more secular than religious. Or, on Conception Day, you may see the Indian women, white-hooded, the ladinas in black shawls, standing with lighted candles on each side of the street, while the figure of the Virgin is borne, also by women, through the darkness of the night.

The Indians like noise in their services. At vespers you may hear the roll of the native drums within the church, while from without comes the crack and bang of exploding rockets and bombs; and as night falls clouds of incense, from censers swung by Indian boys, float through the merciful darkness, to veil, with a passing sanctity, the tawdry gilding of the altar, and of the gaudy dolls that, in the daylight, flaunt horribly their ugliness in the often neglected church.

Their love of rocket-firing amounts to a passion. No ceremony is complete without them, whether the occasion be joyful or solemn. The swish of a rocket begins a fiesta, and ends a funeral. The sale of gunpowder being a Government monopoly, I understand that little discouragement is offered to the organisers of pyrotechnic displays.

One word upon the native tongues.

The pronuuciation of the whole of the native languages is very guttural. Humboldt says " nothing strikes Europeans more than the excessive length of the words. This length does not always depend on their being compounded, as in the Greek, the German, or the Sanscrit; but on the manner of forming the substantive, the plural, or the superlative. A kiss is called, in the Mexican language, tetennamiquiliztli," 
a word formed simply from the verb to cmbracewith which I shall not inflict the reader-and its particles te and litzli. Personally, I should prefer to use Ronsard's definition, and call a kiss simply "le point qu'on met sur l'i du verbe aimer." But the above is nothing to what the Central American can do. His best terminological efforts eclipse even Shakespeare's much-debated "Honorificabilitudinitatibus," in Love's Labour's Lost; for if you wish to recall, in Mexico, the messenger who carries a paper on which tidings are printed, you have but to murmur, " amatlacuilolitquitcatlaxtlahuille," and he may possibly come.

The natives of Guatemala are mostly engaged in agriculture, being employed on the large coffee fincas, banana estates, or cocoa plantations, or else owning land on one of the many Government estates set aside for their benefit. They make excellent agricultural labourers, being contented to work patiently for hours in the blazing sun, and expecting but little more than their food, clothing, and shelter. ${ }^{1}$

Mention must be made here of the large number of Chinese in Guatemala City, and in other towns, especially on the Pacific coast, where they own shops, the inevitable laundries, and other business establishments, forming quite a colony, and giving to certain portions of the city a semi-Oriental appearance.

John Chinaman, however, behaves himself in Guatemala, knowing that it is best that he should; and crime, therefore, with the possible exception of occasional occurrences of the form of criminal assault peculiar to Chinese, is as rare among this section of the population as it is among the natives.

${ }^{1}$ Although these natives will work patiently for hours at a stretch, they object strongly to being hurried. 



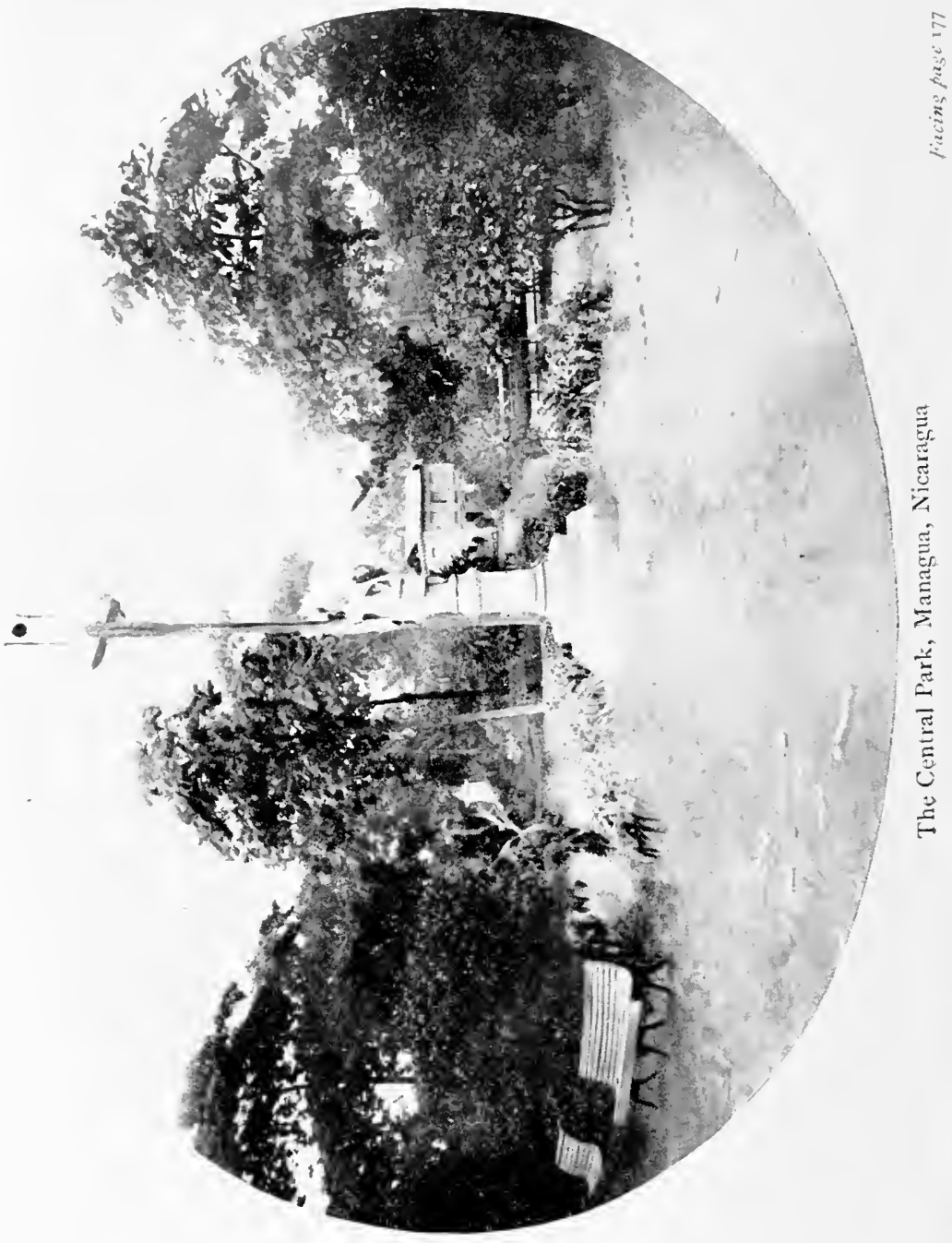


PART II

NICARAGUA 



\section{NICARAGUA}

\section{CHAPTER I \\ "NICARAGUA THE BEAUTIFUL"}

IN order to appreciate the present economical standing, and possible future development, of a nation, it is vitally necessary to study, not only its history and internal aspect, but also the past and present of its neighbours and commercial rivals. If, for instance, we say that Guatemala is, at present, the most important country in Central America, the questions immediately ariseWill she maintain her position in the face of the competition of the surrounding countries ? Is she naturally richer than they? Is war between them probable? Is it better to invest money in Guatemala than in, say, Costa Rica? There arise a host of other problems, which, although affected by the material prosperity of one country, cannot be solved until all the countries in the same zone have been clearly reviewed.

To do this fairly, it is not imperative to devote the same space to each ; rather, by discriminating between the facts that are vital to the issue, and those that are merely superfluous, we can apportion the space devoted to each country, according to its present position, and its future possibilities. Were equality of review to be the primary factor, the reader would quickly get confused by the mass of conflicting evidence brought forward in the defence of each country, and, probably, would be no wiser after than before; moreover, the 
customs of all the Central American countries so much resemble each other that repetition, in many cases, is quite unnecessary.

Nicaragua, which lies in the south of the isthmus, and is divided from Guatemala by the two smaller republics of Honduras and Salvador, contests with Guatemala in the matter of size! It must be stated here that the surveys of these comparativelylittle-developed countries were mostly very indifferently carried out, many years ago ; and, in some cases, only old and unreliable maps can be obtained. ${ }^{1}$ Hence the difference of opinion concerning the area of each country; but, while the figure 46,774 square miles, that more recent surveys give as the size of Guatemala, seems to be fairly accurate, the 49,500 square miles named as the area of Nicaragua, a country less developed, more beautiful, but much less accessible, seems far more open to question. But, accepting these figures, Nicaragua is the largest of the five Central American states. ${ }^{2}$

As regards population, Nicaragua can muster only about 600,000, as against Guatemala's 2,000,000; and the great majority of these live in the five towns of Managua, Leon, Masaya, Granada, and Rivas, all of which are situated on the neck of land lying between the great lakes and the Pacific, although there are small groups of towns (!) and villages on the shores of the two largest lakes-viz. Lake Nicaragua, 96 miles long and 40 miles wide, which is connected with Lake Managua, 38 miles long and 16 miles broad, by the San Juan river. There is also a somewhat scattered rural population, especially in the interior highlands of Segovia and Matagalpa. Between the lakes and the Atlantic seaboard lies the vast area of Nicaraguan land, as yet but little exploited. Bluefields, one of the most healthy

1 Meaning survey maps:

2 The vast area of the Nicaraguan lakes must, however, be taken into consideration. 
towns on the east coast of Central America, is the only populous centre on the Atlantic seaboard.

The interior of Nicaragua is extremely wild, and prolific in views of exquisite grandeur. In this respect it is certainly superior to Guatemala. Plateaus lofty, desolate, yet fertile and healthy, rise high above square leagues of dense, primeval forest rolling away to the dim horizon veiled in a warm mist, through which occasional gleams of sunlight flash, like heliograph signals, upon the placid surface of the lake. Vast plains alternate with tropical forests abounding with valuable woods, and these give place, near the Atlantic coast, to low-lying swamps covered with tall, dank grass, and the tangle of tropical jungles and morasses.

In these regions, explorers may still find the glamour of the unknown. Rugged mountains rise up, lonesome and grand, to austere, rock-capped summits silhouetted against the cerulean blue of a torrid sky. Cool breezes sweep the desolate plains on the plateaus around Segovia and Matagalpa, making these vast grass-lands eminently suitable for colonisation, as in the highlands of Guatemala ; while on the lowlands of the coasts, and in the primeval forests, the heavy odours of rank vegetation, and the voracious mosquitoes, are there in abundance to remind one that, although all around teems with exuberant life, death lurks in the shadows.

And here may be mentioned a feature which goes to prove the old saying, that the clearest water is the most dangerous ; for in these swampy jungles one often comes upon pools of water which look sparkling and clear when held in a phial to the dim forest light, while, in the dusty highlands, the water is often muddy and dull ; yet, were you to ask a peon or native which he would sooner drink, he, after assuring you that aguadiente is better than either, would unhesitatingly refuse to try the clear agua from the lowlands.

What a pageant can Nature show in this " best garden 
of the world," where the forest palm lifts a feathery head above the lighter foliage, and the flowering shrubs, ablaze with scarlet and gold, embower the stream; where birds are as bright as the flowers, and as varied as the leaves ; where parrots flit, green, blue, and yellow ; macaws brilliant as fire; restless jays on azure wings ; where water-spiders, shining like carbuncles, seek their prey ; where lizards, lovelier even than those of temperate zones, raise tall red crests and swell purple throats as you pass beneath the boughs. 'Tis an Eden that, though without an Eve, lacks not the serpent. In the pellucid waters of the stream, beneath the tree, coiled up, he lies there, deadly, venomous. Other dangers there are; not less real because unseen. Within that thicket is the jaguar's lair ; behind that bush the sleek panther, yawning cavernously, stretches forth, from beneath velvet pads, weapons sharpened for murder. Here, as elsewhere, creation, animate and inanimate, though gloriously fair to look upon, is yet red in tooth and claw. Horrible, in the jungle night, is the deathcry of the stricken deer, as, with great teeth tearing at its neck, it makes its last futile rush beneath the forest boughs.

Few but prospectors for gold-and gold exists in Nicaragua in considerable quantities-have penetrated far, or often, into the remote interior. The region south of the mountain range, and on the Costa Rican frontier, is, to white men, almost a terra incognita; though not for the reason that it is arid like the largest portion of the French Soudan, nor very unhealthy, like the "fly country" in Portuguese East Africa, but because it lies back from the main stream of commerce and enterprise, and has not yet been linked, by the railway line, to the outer world of life, and energy. It is no exaggeration to say, that many thousand square miles of Nicaragua territory, vast areas of which are extremely fertile, lie unexplored and uncared for, while the struggle 
for land and commerce, in several of the South American countries, proceeds at a rate which, notwithstanding their undoubted richness, is truly remarkable.

The Pacific coast of Nicaragua, bounded on the north by Honduras, and on the south by Costa Rica, is far more precipitous and drier than the Atlantic slope, in which respect it follows the general characteristic of the other states. The rivers flowing into the Pacific are few in number, and meagre in volume, while no less than twelve important rivers flow eastwards to the Atlantic. The chief of these are the Coco, Escondido, Rio Grande, and the Kurringwas, all of which extend half-way across Nicaragua, and in some cases are navigable for several hundred miles from their mouth. These fluvial highways, spreading fertility on either side, should prove beneficent factors in the rapid development of the Atlantic slope of Nicaragua.

Visit the cities of Leon, Managua, or almost any portion of the western region, in the torrid heat of the dry season, and the whirling clouds of loose, volcanic dust will live long in your throat, much longer in your memory.

To judge Nicaragua by such a visit would, however, be grossly unfair, for, when the rains commence, the scene completely changes. Trees everywhere clothe themselves in a mantle of feathery green, and bushes, which, during the dry season, are gaunt and bare for want of moisture, awake, as if by magic, and burst forth into clusters of pale pellow, white, and emerald-green ; while the hot, dusty plains, whose glitter almost sears one's eyes, as does a glance at the summer sun, atone by a green freshness that, in places, recalls an English spring.

The sun does not take his departure when the heavy clouds and the rainstorms come. Even in the midst of the wet season, Nicaraguan highlands are, for hours a day, bathed in sunshine. 'Tis a picture of almost 
Arcadian beauty, but, as in the lovely, isle-dotted bay of Panama, among the vivid lights and mystic shadows so characteristic of Cairo and the Nile, on the Golden Horn of Constantinople, and in the blue isle of Capri - to mention only a few of the world's beauty spotswhen no longer distance lends enchantment to the view, there are blemishes and climatic disadvantages that remove it from the elysian sphere, but do not rob it of the honour of being one of Nature's pageants, any more than the climb to an Alpine summit in the cold of early hours, when the valleys below are silent and asleep, detracts from the beauty of sunrise over the glaciers of the Bernese Oberland. 


\section{CHAPTER II}

\section{NICARAGUA'S SHARE IN THE HISTORY OF CENTRAL AMERICA}

From the earliest times, to quite recent years, Nicaragua has been the playground of soldiers of fortune. Many are the names of Spaniards, Americans, and Englishmen who have made pages of history by their daring deeds on Nicaraguan soil.

The early career of this Central American state is similar to that of the neighbouring countries.

Spanish power crept swiftly southward, starting with the conquest of Mexico by Hernan Cortez, the quick and daring occupation of Guatemala by his lieutenant, Pedro de Alvarado, and followed by the despatch of numerous expeditions to subdue the remainder of Central America. The ill-fated Nombre de Dios colony was transferred to Panama City by Pedro Arias de Avila, who immediately sent expeditions into Nicaragua and Costa Rica, where trouble and fighting arose between the natives and the Spanish invaders, resulting in the annexation of these countries to the newly formed "Kingdom of Guatemala."

Governors came from Spain to rule over each of the four divisions into which this portion of the Spanish colonial empire was divided; but superior to them all was the Captain-General of the Kingdom of Guatemala, where sat also the famous council, known as the Audience, which possessed almost unlimited authority, being second only to the central powers at Madrid.

Thus it will be seen that, in the days of the Spanish 
dominion, all the states, or provinces as they were then called, of Central America, were more or less subservient to Guatemala with its Audience and Captain-General. Many were the governors sent out from Spain, from the time of the conquest of Guatemala in $I_{524}$ to the Proclamation of Independence, early in the nineteenth century. Some of these were wise administrators and honourable gentlemen, while others were cruel oppressors, and dishonest, both in their dealings with the people and with the Cortes.

The fifteen years of Spanish rule was of a terribly bloody character. The natives were looked upon more as cattle than as human beings, and their ruthless extermination, during these few years, accounts, in no small degree, for the slow agricultural development of these colonies, and for the acute necessity, afterwards felt, for the importation of slaves from the adjacent West Indian islands (some of which were also under Spanish rule), and from the Guinea coast of South Africa.

This slaughter of innocents continued in all parts of Spanish America, until I537, when Father Bartolomé de las Casas succeeded in influencing Pope Paul III. to issue the famous bull declaring the natives to be "true men," and not animals, as was generally believed.

Although this decree had certainly a strong, beneficent influence, it was many, many years before the Spaniards learned to treat the unfortunate aborigines even as valuable slaves.

Mr Boyle has pithily summarised the careers of the five earliest rulers of Nicaragua. "The first was a murderer, the second a murderer and rebel, the third murdered the second, the fourth was a forger, and the fifth a murderer and rebel. Verily, if the Devil reads history, his favourite work must be the conquest of America." 
Passing over the three centurics of the Spanish rule, we arrive at that period of modern history when the foundations of the political world were being shaken violently by the spirits of revolt and republicanism.

The angel, or, as, in the light of our recent English experiences, I prefer to name it, the demon of unrest had swept over North America, and England had lost many of her valuable colonies on that continent.

France had been steeped in the blood of the aristocrats, and was trembling in the aftermath of civil war, while the nations of Europe watched the growing power of the great Napoleon.

Then, during those years of rapid evolution, I80oI82I, during which time Napoleon, although ultimately defeated, had crippled the power of Spain and Portugal, South America threw off the yoke of Spain, to be quickly followed by Mexico, and the states of Central America, who proclaimed their independence on the I $5^{\text {th }}$ day of September I82I.

After the overthrow of Spanish power, these countries found themselves in a state of financial and commercial bankruptcy, and political chaos. This is scarcely surprising, when it is remembered that, during the Spanish dominion, education of any but a superstitious and religious character was non-existent, except among the wealthy classes ; and even literature was bereft of its widening influence by the strict censorship on all imported books. Mining had been largely carried on, but so incessant was the demand in Spain for specie from these colonies, and so crude were the methods employed, that, although lives had been ruthlessly sacrificed in tearing the gold and silver from the earth, only rich surface deposits had been worked; and these, long before the dawn of the new era, had been exhausted by such wasteful and short-sighted methods.

Tobacco and cocoa were then the staple products; agriculture, on anything like a large scale, being 
neglected, although the comparatively fow natives cultivated their ficlds of maize, cassava, and beans! Little there was of industry, other than mining and native craftsmanship, while the overseas commerce had been almost entirely restricted to the motherland.

Such was the condition of these countries when they proclaimed their independence from Spain, and it is scarcely to be wondered at that, having suddenly severed their ties with the motherland, and finding themselves in a condition of utter chaos, without organised commerce, revenuc, or form of government, and almost entirely devoid of intelligent leaders, they were immediately plunged into a period of civil warfare and darkness, through which the light of reason did not penetrate for nearly half-a-century.

Many and fierce were the fights that took place in Nicaragua during these stormy years, though only a few of them are recorded, even in the annals of local history. One of the wisest leaders in Central Amcrica, at this time, was Morazan, whose chief aim it was to compel, even by force of arms, if necessary, the union of the five states of the isthmus. This was the beginning of the "Federation Movement," which, notwithstanding failures and sweeping modifications, has continued to the present day to be la grande scheme politique.

Morazan, however, was not only defeated on the field of battle by the Guatemalan general, Carrera, but fell a victim while endeavouring to compel the adoption of his great ideal. Although actually accomplished for a brief period, the federation of the five republics fell to pieces after the death of this undoubtedly wise leader; yet the schemes of men live after them, and although the union by force of arms was given up before many years, as impossible of accomplishment, peaceful endeavours to secure the federation of these states have continued uninterruptedly to the present day.

In I897, a federation was again constituted, under 
the title of " Republica Major de Centro-America," but Salvador withdrew from this union, in I898, owing to a revolution which succeeded in overthrowing President Gutierrez, and placing in power General Tomás Regelado, who was opposed to the federation. War, over boundary claims between Nicaragua and Costa Rica, was narrowly averted.

Yet another attempt to federate was made in later years, and the seat of supreme government was fixed at Amapala, where a council sat to elect a president ; but this attempt, like the previous one, failed through lack of cordial co-operation, and, as described elsewhere, renewed efforts are now being made by President Estrada Cabrera, of Guatemala, to effect this longsought-for union of Central American States.

Going back to the fifties, the true story of the Walker Expedition will sound more like chapters from some of the late Mr Guy Boothby's famous romances, than actual happenings in the nineteenth century.

Previous to the coming of Walker, in I855, Nicaragua had been torn, for over thirty years, by internal strife, and in that year a revolutionary war was in progress, between the Legitimists, headed by the President, Fruto Chamorro, with their headquarters in Granada, and the Democrats, led by Castellon and Muñoz, with their base of operations in Leon. Each party was sufficiently powerful to prevent the other from dominating Nicaragua, and Castellon had proclaimed himself "Provisional President," with Muñoz as Commander-in-Chief of the army.

The mediation of the surrounding states had proved unavailing, and neither party could inflict a decisive defeat upon the other. Matters were at a climax. It was then that the idea occurred to Castellon, to enlist the services of a "foreign legion," to enable him to strike a decisive blow at the Legitimists in Granada. In December 1854 he signed a contract with an 
American citizen, named Byron Cole, who agreed to return to the United States, to form a regiment of voluntcers, 200 strong, and to bring these to aid the revolutionary army in Nicaragua, on the condition that they were to be directed by their own officers, under the supreme command of General Muñoz. In return for their services during the war, these soldiers of fortune were to be paid a stipulated daily wage, and themselves, or their heirs, were each to receive two hundred acres of land in Matagalpa, or New Segovia, on the successful termination of the rising.

General Muñoz was against the enlistment of foreigners from the first, and pointed out the dangers incurred to Castellon, who, however, was more than ever determined to bring the revolt to a successful conclusion by decisive action.

Cole returned to San Francisco, and, after protracted negotiations, transferred his contract to William Walker, an adventurer well known in Central America and Mexico, where, two years before, he had aided an unsuccessful revolution. Walker obtained a promise of assistance from the planters of the Southern States, who were beginning to look around for fresh fields, where they would be free from the anti-slavery agitation which preceded the war between the North and South.

Walker was a small, wiry man, about five feet four inches in height, clean shaven, except for a thick moustache, with fair hair, and large, prominent, light grey eyes. His manners were grave and taciturn. Brave, without being reckless, resolute and determined, of a type of character, half savage, half heroic, still common in the Latin states of America, he was a model leader for the desperate characters with whom he had afterwards to deal, "Gay was the scene in San Francisco City when Colonel Walker, the idol of the adventurous, opened his enlistment offices. All over the town were posted bills headed 'Beauty and Booty' 
and calling on the filibusters of Sonora and New Orleans to join their most brilliant leader."

While these arrangements were being made by Walker, who now assumed chief command of the foreign legion, a year had nearly passed by, and although Castellon had succeeded in holding his own, no advance of the revolutionary forces had been possible. Muñoz tried to open peace negotiations with the Legitimists in Granada, but failed, and the year I855 had scarcely dawned when Chamorro died, and José Maria Estrada became "President" of the Legitimists.

It was in this deadlock that Walker, with 55 men, arrived at Realejo. Although the number was far below that arranged with Cole, Castellon welcomed the addition to his forces, and ordered Walker to advance, with Colonel Mendez and Ioo Nicaraguans, on Rivas, then held by the enemy. An action took place, in which Walker's force was badly beaten, owing to the lack of support accorded by Mendez.

After this defeat, Walker returned to Realejo, and complained to Castellon of the behaviour of Mendez, in refusing him the necessary support. Although Castellon received him in the most friendly spirit, Muñoz, the rebel commander, was cold and distrustful, and suggested dividing Walker's corps among the regiments of the revolutionary army. Walker, naturally, would not agree to this, and valuable time was lost in useless discussion.

Early in August, the revolutionary forces again advanced, and an action took place near Sauce, shortly after which General MIuñoz died from cholera, which was then ravaging this unfortunate country.

Walker's opportunity had arisen; he began to take full advantage of it. His prestige as a military leader had grown rapidly, and over 300 Nicaraguans had joined his corps. In September he arrived at La Virgin, a small port on Lake Nicaragua, and here met, 
and defeated, a Legitimist army under Guardiola. From this point, he ascertained that Granada had been left ill protected, the main Legitimist army, under Ponciano Corral, being situated at Rivas. Quickly embarking his men on lake steamers, he advanced on Granada, and captured it by surprise.

With these successes Walker rested content for several days. Corral, however, hearing of the fall of Granada, marched from Rivas about the middle of October, with 500 men, but, on the way there, he was met by an envoy from Walker, who proposed, in the message sent, that as Corral and himself were the two strongest men in Nicaragua, they should come to an agreement on the basis of equality, Corral becoming President and Walker Commander-in-Chief of the Army.

The temptation proved too strong for Corral to withstand, and he retired on Masaya, to consult with the Legitimist President, Estrada.

Walker, gaining time by this strategem, greatly strengthened his position around Granada by methods of defence, and also by conciliatory proclamations that gave him many new adherents. He released a hundred men from the local jail, who immediately joined his following, and, about this time, another hundred American volunteers arrived, adding materially to the forces at his disposal.

Estrada refused to consider Walker's proposals for peace, and Corral hesitated to accept them. In order to force their hands, Walker committed the first act of brigandage in the war, and thereby alienated a large number of his more respectable adherents. He seized the chief men of Granada as hostages, and had one of them shot.

Walker's triumpl was now complete. The entreaties of the Legitimist captives, coupled with the strength of Walker's position in Granada, forced the hands of 


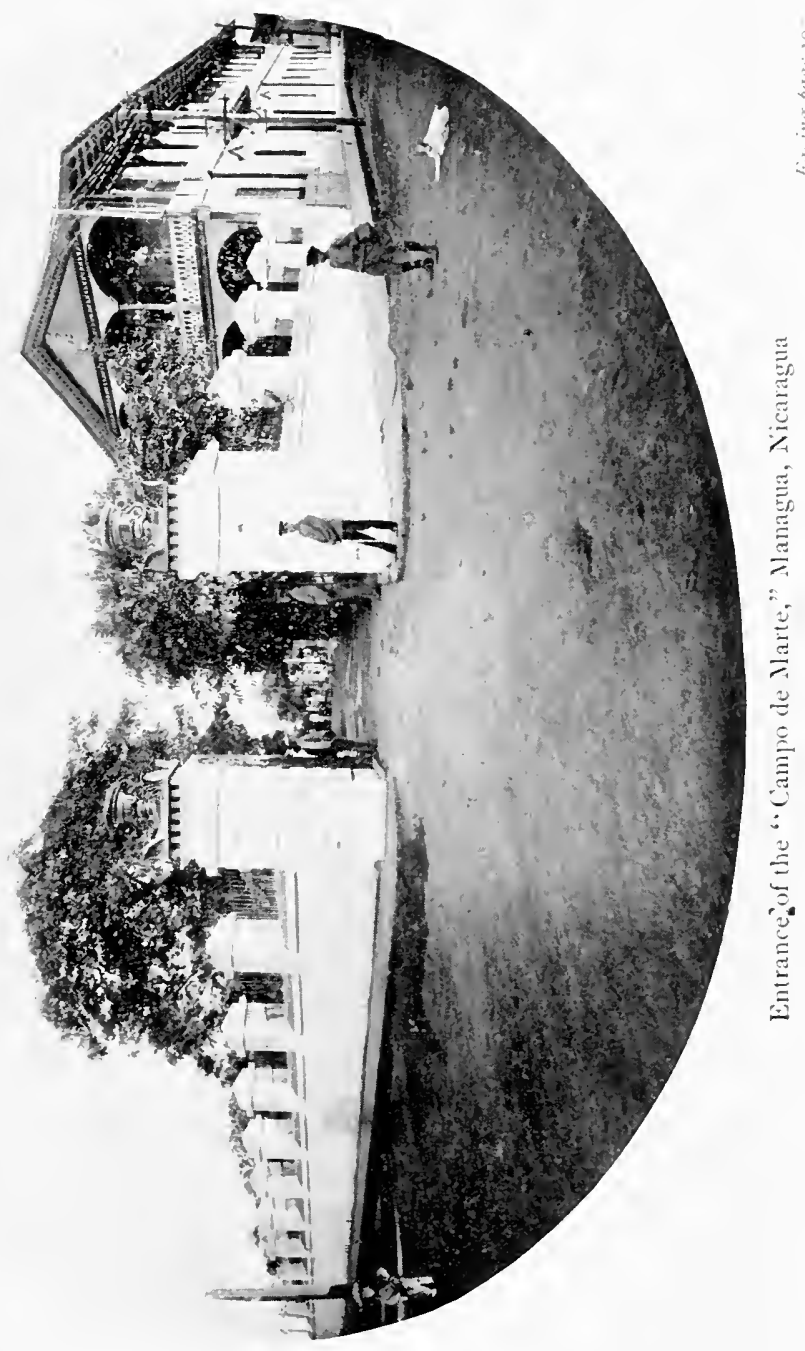



President Estrada, who despatched Corral to make the best terms possible. No longer did Walker offer the presidency to Corral ; and Estrada's claim, as the chosen of the Legitimists, was likewise ignored. Patricio Rivas was made President by Walker, who, however, gave Corral the nominal command of the army, but retained the active command himself, and became virtually Dictator of Nicaragua.

About this time, Walker got into bad odour with the United States, partly through his proposing Nicaragua as a country to which the slave-owners of the Southern States could come and be sure of protection, and still further by his seizure of the steamers on the lakes and rivers belonging to the transit company controlled by Vanderbilt. He also made many enemies in Nicaragua, by his summary disposal of Corral, whom he suspected of treachery, and ordered to be shot.

War was declared by Costa Rica against Walker, in March I856, and the Costa Rican forces were successful in the first engagement at Santa Rosa, a victory which they rapidly followed up by inflicting a crushing defeat upon their adversary at Rivas, on the IIth of April.

Walker, becoming alarmed at these repeated disasters, made terms with his old comrades, the Democrats, who had been alienated by some of his recent acts; by so doing he stemmed, for a time, the tide of Costa Rican invasion. Plots against Walker were cverywhere rife, and only by drastic measures could he now maintain his position. Rivas, suspected of treachery, was replaced by Fermin Ferrer ; but the former was supported by the republics of Salvador and Guatemala, while the old Legitimist leader, Estrada, who had been waiting his opportunity in Honduras, crossed the frontier, and raised his standard, to which flocked numbers of his old comrades.

Walker decided, as a counterblast, to proclaim him- 
self President; and after the necessary clections had taken place, in which he managed, in some way, to secure a large majority of votes, he was duly inaugurated, in the presence of the United States Minister, who had received instructions to recognise him, on I2th July I856. The ceremony took place in the plaza of Granada, where flattering speeches were made by Ferrer, the retiring president, Father Vigil, who had returned from the United States, where he had been for a time as Nicaraguan Envoy, and many others.

Walker, who, notwithstanding his unscrupulousness, had hitherto shown such remarkable ability as a leader, now appears to have become intoxicated with his own power. Instead of pausing, to allow the anger which surrounded him to abate somewhat, before offering the iron liand of mastery beneath the velvet glove of clemency and friendship-as would certainly have been the wisest course, considering that all the surrounding states were hostile to him, and that even his own army and the people of Nicaragua were tired of the incessant warfare which had been raging in their midst for so many years-he immediately proclaimed a policy as startling as it was unwise. Among his first decrees was one establishing English as the official language for all Government purposes; another was to confiscate all the property of any party opposing him, while, at the same time, he gave all his associates grants of land, or haciendas of cocoa or sugar, and fincas of coffee, which he wrested from their rightful owners upon the slightest excuse. This suicidal policy he followed up with the most disastrous decree of them all-one for the re-establishment of slavery.

Within a few wecks, the whole civilised world, with the possible exception of the Southern States of America, whose interest naturally made them more sympathetic, were loud in their protests against him. England despatched warships to Central American waters; 
France and Spain protested at Washington; while Brazil, Chile, and Peru offered arms and money for his overthrow.

Estrada, the Legitimist President, was assassinated in August, and his place, as leader of this party, was taken by General Castillo. The allied forces of Guatemala and San Salvador joined hands with the Legitimists, who, gaining moral support from the advancing forces of these two states, marched on Masaya early in September.

Walker retired on Granada, which he strongly fortified, but, as his food-supply was endangered by the presence of the Legitimist forces on the surrounding plain, he gave Byron Cole, the originator of the expedition, a small force with which to effect a surprise attack on the Legitimists, before they had time to join hands with the Guatemalan and Salvadorian armies, which were rapidly advancing to their assistance. This was Cole's first experience of warfare ; and his inability to lead irregular troops in the field was quickly proved. His force attacked the farm forming the centre of the enemy's position, but was beaten off and routed. So fierce was the pursuit that Cole was killed, and only a few of his following escaped.

This ignominious defeat of the Presidential forces so damaged Walker's prestige that he determined to concentrate, and strike a decisive blow at the Legitimists in Masaya, in order to recover ground.

But this time his intelligence department failed him.

Leaving Granada with a large force, he marched on Masaya, and attacked the enemy who occupied the plaza. Alter a desperate fight the position was seized and held for one night, but had to be evacuated before sunrise, on receipt of the news that, in the meantime, the Guatemalan army had come up in his rear and attacked Granada. Hurrying back to the assistance of 
his beleaguered capital, Walker beat off the Guatemalan attack, only to hear that Costa Rica had again risen in arms against lim, and, early in November, had attacked and captured the city of Rivas.

It was at this period of the campaign, when the fortune of war was turning against Walker, that Colonel Henningsen, an English soldier of fortune, who had won considerable fame as an organiser of artillery, arrived on the scene, and succeeded, for a time, in stemming the tide of disaster.

The line of the transit being of the utmost importance to the Presidential army, Walker decided to drive the enemy from the city of Rivas, which partly dominated that line. In order to do this, he instructed Henningsen to remain behind with a considerable force, and, as a lesson to the Legitimists, to burn the city of Granada to the ground.

Walker occupied the city of Rivas without a struggle, the enemy having retired, under orders from the Salvadorian general Belloso, who had been placed in supreme command of the allies in Nicaragua.

Henningsen, in order to carry out the other portion of the scheme, divided his force into four parts, with the object of setting fire to the town on all sides at the same time. This was successfully accomplished, and the old Spanish city of Granada was burnt to the ground, though not without considerable loss, for the Salvadorian army fell on them while the divided forces were running riot through the town, and inflicted a severe defeat. Henningsen, with a few hundred men, escaped to the old church of Guadaloupe, situated between the city and the lake, where, although lacking water, provisions, and ammunition, he held out for eighteen days, against 3000 allies. He was relieved, on I2th December, by a small force, which arrived by way of the lake ; then, with this reinforcement, which brought his numbers up to about I30 men, he broke through the 



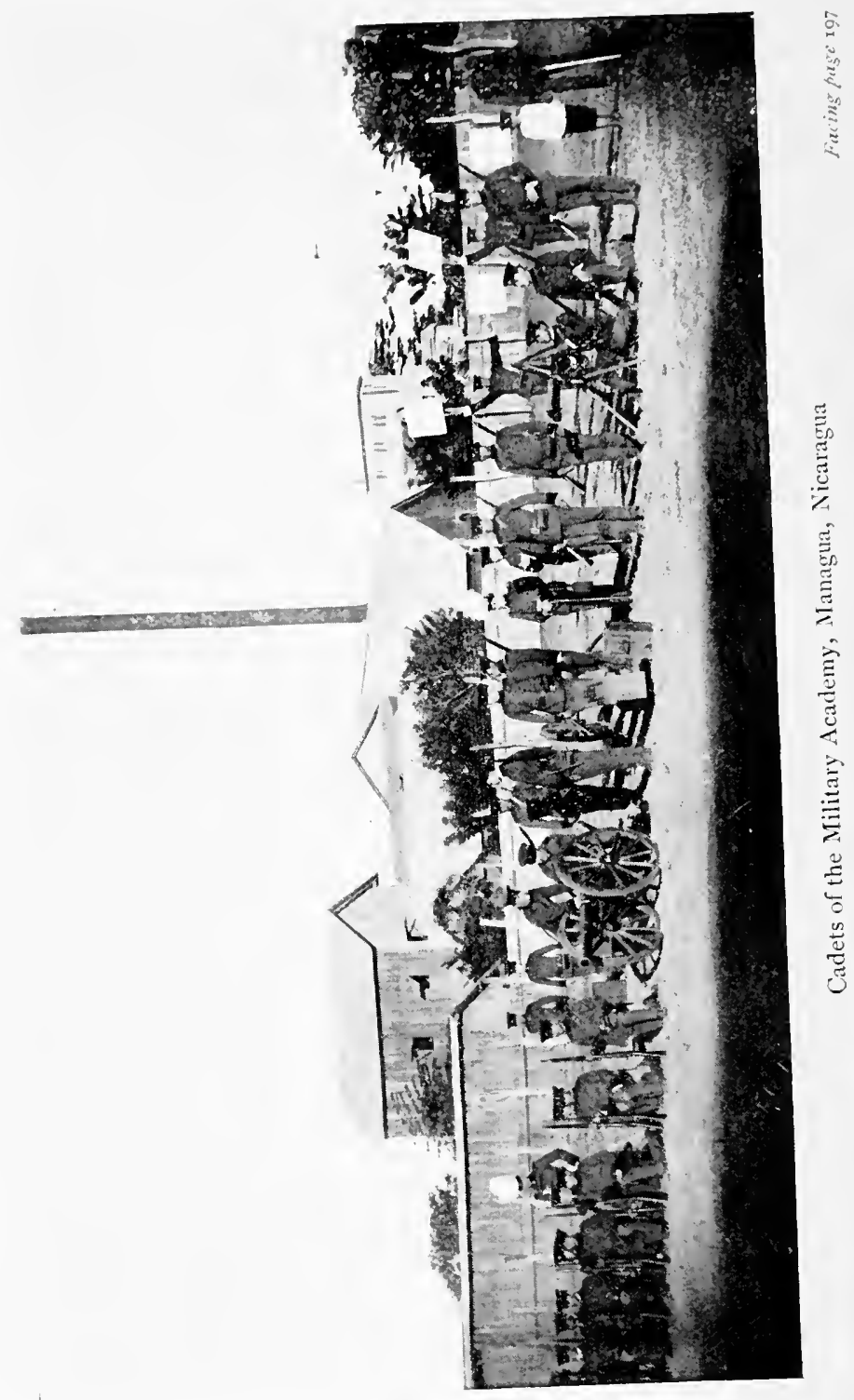


investing lines, and sailed away, in a lake steamer, in full view of the allies.

Notwithstanding these gallant exploits, Walker's forces were being slowly hemmed in by the overwhelmingly superior numbers of the enemy. Costa Rican gunboats were patrolling the Central American coasts, preventing the entry of American volunteers, of whom some hundreds made the attempt, while British warships offered to take back to the United States all Americans who wished to leave Nicaragua. Many deserters from Walker's forces, who saw his star of fortune rapidly falling, took advantage of this offer.

General Jose Joaquin Mora of the Costa Rican army now assumed chief command of the allies. Walker had fortified the plaza of Rivas, and held it tenaciously against all assaults, until, finding himself hemmed in on all sides, he surrendered, on Ist May I857, to Captain Davies, of the United States gunboat, Saint Mary.

Walker and his comrades were conveyed back to the United States, where they received a popular reception. With his able lieutenant, Henningsen, he rapidly prepared for another attempt to assert his power in Nicaragua.

Assisted by money, men, and arms from the United States, where, by lecturing and writing, he had aroused great enthusiasm, he took advantage of the war that had broken out, in November of the same year, between Nicaragua and Costa Rica, to effect a landing at the mouth of the Colorado river, where he captured the Puenta de Castilla, but was prevented from advancing farther by the arrival of Commodore Paulding in the United States gunboat, Wabash, followed by the gunboats, Susquehanna and Fulton. Again he was taken back to the United States, and this time tried before the courts at New Orleans, but was quickly acquitted, on the plea that he was legally the rightful President of Nicaragua, fully recognised by the powers. 
In 1858, the following year, Walker set out from Mobile on his third expedition to Nicaragua with 140 men, in the good ship, Susan; but his vessel was wrecked on Glover's Reef, off the coast of British Honduras. Rescued by a boat from Belize, his party was again sent back to the States, this time by the British authorities.

Nothing daunted, however, with a spirit truly Napolconic, he organised yet another expedition, in I860, and in June of that year commenced his last ill-fated invasion.

This time he acted at first more cautiously, establishing his headquarters at the island of Ruatan, off the coast of Honduras. Here he mobilised his forces, and, early in August, attacked and captured the town of Truxillo. Honduras, alarmed at this success within her territory, moved a large body of troops to the scene of action, and Guatemala also took up arms against him, and asked help from the British authorities at Belize.

Walker made his greatest blunder when he violated Hondurean territory, as this was an act of brigandage, and, moreover, the Truxillo custom-house was, at that time, under British control, which caused the authorities at Belize to despatch immediately the British gunboat, Icarus, to demand his surrender. If he had restricted himself to Nicaragua, it is doubtful whether extreme measures could have been taken against him-even had his expedition failed, and he himself been again compelled to surrender to a United States warship-as, legally, he was President of Nicaragua, and, as such, could scarcely have been indicted as a dangerous rebel, far less shot as a murderer.

Walker, at first, refused to surrender to the British gunboat, which was quickly joined by an armed Hondurean vessel, and, notwithstanding the fact that promise of life was given to all, except Walker and Rudler, his lieutenant, this reckless leader surrendered without 
firing a shot. All except the two leaders were sent back to the United States. Rudler was tried, and sentenced to four years' imprisonment, while Walker was condemned to death by the Hondurean courts, and was shot, early on the morning of I2th September.

It will be interesting to give here Walker's view of these closing episodes in his career.

"I hereby protest before the civilised world, that when I surrendered to the Captain of H.M.S. Icarus, that officer expressly received my sword and pistols, as well as the arms of Colonel Rudler; and the surrender was expressly, and in so many words, to him, as the representative of her Britannic Majesty.

\section{"William Walker."}

Yet the captain of H.M.S. Icarus gave him up to Honduras, with what result we have just seen.

Mr Boyle, writing about the year I865, wields an eloquent pen in defence of Walker. He wisely refrains from commenting on the proposed slavery decree!

"It was no patriotism which roused the five republics to unite in driving out the handful of invaders. It was envy and wounded vanity, and secret ambitions ; and, on the part of some, a very dread of quiet and order.

Boyle then proceeds to make good his case with some scathing comments upon the condition of Nicaragua before and after Walker. We, too, confess to a certain sympathy with ill-fated swashbucklers. Men-certain men-are born into this world adventurers, pirates. Their ideal life is that of Robert Louis Stevenson-to ride at the head of a troop of guerrilla cavalry, to sail the Spanish main. But, alas! there is no new land into which to ride-not even at the Poles-there is no sea that the armoured warships do not guard. Soon there will be not a scrap of God's earth that you cannot visit for sixpence at the Holborn Empire. We are grown circumspect. So little room is there for ad- 
venturers now that I value a Walker as I would a last giraffe.

There is yet another phase of Central American history which must receive attention here-viz. the settlement of the Mosquito Coast, and the rule of the late President Zelaya.

Even in the early days, when British buccaneers harassed the Spanish Main, this strip of Nicaraguan coast land, extending from Cape Honduras to the Mosquito Gulf, and inhabited by wild tribes of Mosquito Indians (of Carib origin), was more or less under English influence. Several times, during the seventeenth and eighteenth centuries, it was occupied by English settlers and officials; but it was not until the Mosquito king appealed to the authorities in British Honduras, in the year I84I, to support his claim to Mosquititia, that England took decisive measures to uphold the rights of the native king, and to secure this coast from aggression.

In I84I Colonel Macdonald, Governor of British Honduras, despatched a gunboat to, and occupied, this coast, in order to afford material support to the Mosquito king. Nicaragua appealed, first to England, and then to the powers, but all to no purpose, as England's rights in Mosquititia were indisputable.

During the five years which followed, England strengthened her position, as suzeraine of Mosquititia, by the introduction of numerous settlers. At this time there was much talk of the proposed interoceanic canal through Nicaragua, and, in order that Great Britain might have no control over this proposed waterway, the President of Nicaragua offered the necessary concession of land for this undertaking, first to France, who refused it, and afterwards to the United States. In I849, David L. White, an American citizen, signed a contract with the Nicaraguan Government, agreeing, 
in exchange for the concession, at once to commence the work of canalisation.

American interest in this new and gigantic scheme was soon aroused, and, in order to arrive at an understanding with Great Britain, the Government of the United States signed the Clayton-Bulwer Treaty, in April I850. This treaty, from that day until quite recently, has been the cause of much diplomatic discussion and no small amount of friction between the two great English-speaking nations, as its terms, notwithstanding the elucidatory Dallas-Clarendon Treaty, signed in August I856, were never clearly set forth; although it was expressly stipulated therein that neither Great Britain nor the United States should exercise any exclusive rights or privileges in the canal zone, nor should it be fortified nor obstructed during peace or war, while it was also agreed that neither powers should seize or occupy any Central American territory.

Great Britain fulfilled the conditions of this treaty, by promptly evacuating San Juan del Norte, and that portion of the Mosquito coast which did not form a portion of her recognised colony, British Honduras; but she continued to support the independence of the Mosquito king (son of the former king), who asked for British protection.

England maintained her influence in Mosquititia until I856, when the Dallas-Clarendon Treaty was signed with the United States, whereby England's occupation of Belize was finally recognised.

She relinquished, however, all authority over the Mosquito coast, which remained for some time under the native king, Satu. On Zelaya's accession to the presidency of Nicaragua, he seized this coast. Great Britain protested, but the United States quoted the Monroe doctrine, and supported Zelaya's action.

The deposed King of Mosquititia, henceforth a 
portion of Nicaragua, went to live in Jamaica, where the British Government allowed liim a pension of twentyfour pounds, ten shillings a week. The old Mosquito coast was renamed "Department Zelaya," but since the overthrow of this autocrat, who made himself perpetual Dictator of Nicaragua, against the laws of the Constitution, suggestions have been put forward for again changing the name to one now more popular.

About Zelaya's rule little can be said here, as many of the events of his administration are of too recent occurrence for impartial treatment. Oppression there was rife, if the term oppression may be applied to acts that, to young and turbulent countries, bring peace and prosperity in their train.

Wars there were, almost without end-in I 893 against the Conservatives; in I894 against Honduras; in I896 against Granada, held by revolutionists ; as well as earlier wars and widespread revolts in 1899, r902, and again in the final insurrection, headed by General Juan Estrada, which resulted in Zelaya's flight from Corinto, in December Igog. The revolutionists then refused to accept Zelaya's minister, Dr Madriz, as President, although he was popular with a certain section; and, in Igro, General Estrada was appointed, by the rebels, Provisional President, until the general election in IgII.

Señor Adolfo Diaz, who now occupies the Presidential Chair, was inaugurated in I9II, and his term of office does not expire until I9I6. 


\section{CHAPTER III}

\section{THE COUNTRY, THE CITIES, AND THE PEOPLE}

WHEN the fires are bright in the western sky, and the sun, dipping behind the broad Pacific, is casting a wealth of warm light upon the quaint, palmbordered roads and adobe houses of a Nicaraguan town, it is not difficult to understand why this country has been called "Nicaragua the Beautiful."

Dark shadows creep slowly up the mountains in the background, a purple mist enshrouds the base, but the peaks are blood-red. Away on the plain, yet still catching the fading light, lies the broad, placid lake upon whose shore stands Managua, quiet and slumberous, with picturesque, colonial Spain in its uneven streets, verandahed buildings, and in the dark flashing eyes of its señoritas.

Years of revolution have stunted the growth of this, the capital of Nicaragua, which has a population of only 34,672 . Its buildings are unpretentious, being mostly quaint, one-storey structures, with coloured adobe walls, and wide projecting roofs of red tiles; but, in almost every patio, magnolias, orange-trees, hibiscus, roses, bougainvilleas, and trees grow with such luxuriance as almost to cover the walls, while even the streets are not free from trees and flowers.

The principal building in Managua is the Campo de Marte, the official residence of the president of the republic. It stands opposite the barracks, towards the top of the main street, which is dominated by La Loma -the arsenal. It is a fine, well-constructed building, 
almost cnshrouded in trees and guarded by an encircling wall with turrets at each corner.

The interior fittings and decorations are of a palatial and imposing character, although they lack the majesty of antiquity.

Near the Campo de Marte stands Zelaya House, a handsome building of European style, surrounded by elaborate, high railings. It was specially built for the family of the late president, and is symbolic of the regal state in which he and his relations lived.

Managua is not nearly such a fine nor growing city as the capital of Guatemala; but its situation on the shore of the beautiful lake makes it equally pleasant. It is lighted by electricity, possesses a fine park, the Central, in which a military band plays twice a week ; and it has several large business establishments, nearly all of which are in the hands of foreigners. Like so many Central American towns, Managua suffers from the dust during the dry season, but the climate generally cannot be considered unhealthy, although malaria and other tropical complaints are by no means uncommon at the beginning and end of the rainy seasons.

Managua, chosen as the capital of the republic, in February 1852 , as a compromise between Leon and Granada, both of which, at various times during the revolutionary period, had been the seat of government, possesses one great advantage-viz. its position on the shore of Lake Managua. Although prevented, for the present, from taking full advantage of this beautiful situation, by the railway line that usurps, between the city and the lake-side, a frontage which would be much more picturesquely occupied by a fine tree-bordered boulevard, let us hope that the inhabitants will one day be able fully to enjoy this magnificent expanse of rippling water, so often crowned with sunlight, and girdled, afar off, by mountains clothed in cloud. 


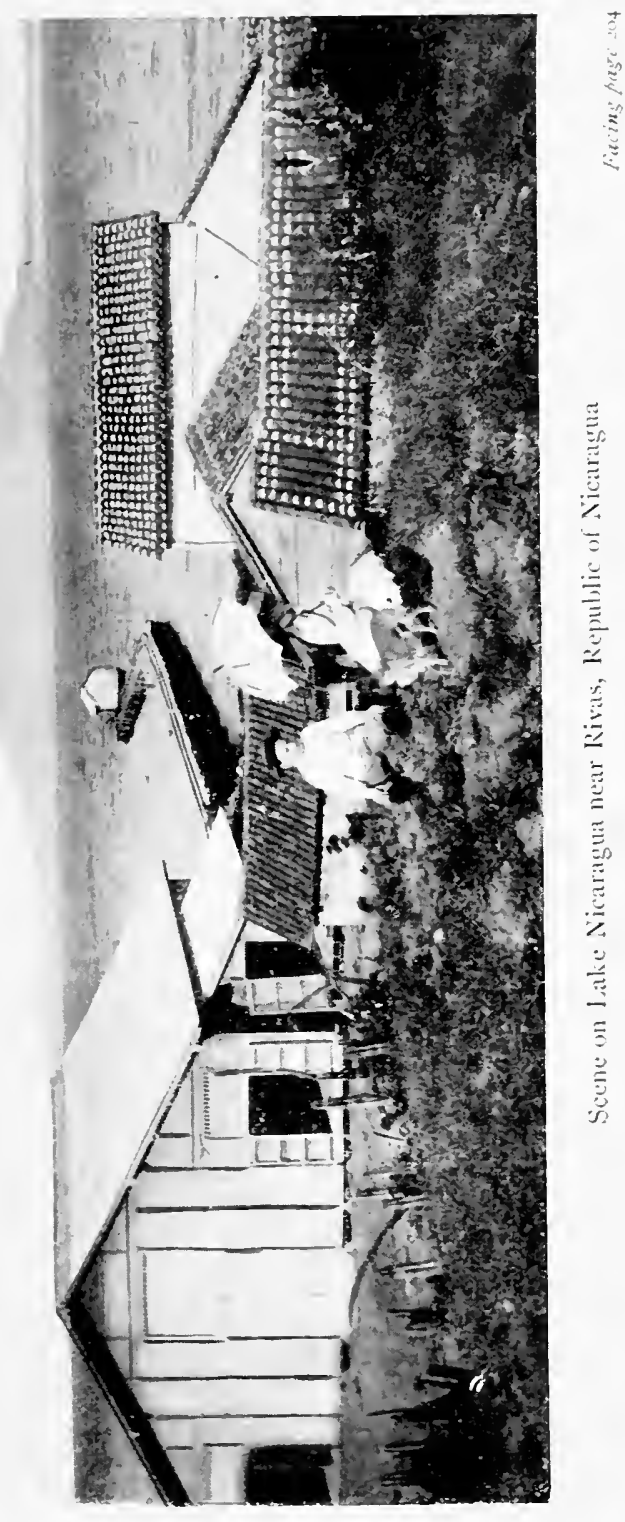





\section{COUNTRY, CITIES, AND PEOPLE 205}

Sunrise on Lake Managua, as seen by many a traveller, is a sight to remember always.

"First a faint light revealed the outlines of the rugged mountains of Chontales and Segovia, followed by a yellow, then a rosy tinge, so faint that it might have been a mere fancy of the spectator; then it deepened, and the clouds, with their glowing edges and purple folds, disclosed their rich, deep masses above the rim of the horizon, while the lake flung back tremulously from its quivering bosom the reflected radiance of the sky. Brighter and brighter, its rays shooting upwards to the empyrean, and glowing on the summits of the volcanoes, higher and higher came up the monarch sun, until, rising above the horizon, he shone forth on the queenly earth, her emerald robes sparkling with dew-drops, and gemmed with flowers " (SQuiter.)

Leon, the time-honoured rival of Granada, is a much larger and finer city than the capital; yet it lacks the picturesque surroundings and beautiful lake that make Managua so attractive. Leon, however, does not stand on the site of the original city - at the foot of the volcano, Momotombo-but on a broad plain, some twenty-five miles to the west.

Grandly, as one approaches it from Azusco, does that plain of Leon open out. World-renowned as the views are of this " country plain and beautiful, full of pleasantness, so that he who fared therein deemed that he journeyed in the ways of paradise," the reality as much excels all anticipations as did Solomon's glory those of the Eastern queen. From the shores of this ocean of verdure, the traveller can look over league upon league of green fields, chequered with hedgerows, clothed with trees, bounded on the right by lofty mountains, whose cones rise spire-like to heaven, circled on the left by low emerald hills, like the seats of an amphitheatre. Beyond the distant purple haze 
can be dimly seen the unbroken waves of the great Pacific rolling to the shore. As you approach the city from the plain, the signs of cultivation and industry become everywhere more numerous, until you can see, whitc and massive, over the tiled roof and green foliage of the town, the towers of the great cathedral, an edifice that would be quite imposing were it not dwarfed to some extent by the works of a greater architect, He whose hand fashioned the nine volcanoes that skirt the plain of Leon.

Leon, which has perhaps suffered more in war than any of the neighbouring towns, was formerly one of the bestbuilt cities in all Spanish America. As Gage, writing in I665, puts it: "The chief delight of the inhabitants consists in their houses, in the pleasures of the country adjoining, and in the abundance of all things for the life of man. They are content with fine gardens, with the variety of singing birds and parrots, with plenty of fish and flesh, with gay houses, and so lead a delicious, lazy and idle life, not aspiring much to trade and traffic, although they have the lake and ocean near them. The gentlemen of Leon are almost as gay and fantastical as those of Chiapos; and it is especially from the pleasures of this city that the province of Nicaragua is called Mahomet's Paradise."

The story of the " trek" from the original town is of more than ordinary interest; as it shows the credulity of the people, and the power exercised by the Catholic fathers, in Central America, during the fifteenth and sixteenth centuries. The old city of Leon was founded, early in the fifteenth century, by Hernan Ponce de Leon, one of the conquistadores. It grew rapidly in population and prosperity, until I549, when Bishop Valdivieso was assassinated in his palace there, by a son of the late governor, Contreras, who escaped for a time, but was eventually killed in Panama City. Some years later, the volcano, Momotombo, broke into eruption, and 


\section{COUNTRY, CITIES, AND PEOPLE 207}

damaged a large portion of the city of Leon that hitherto had nestled cosily at its base. The bishop, remembering the assassination of his predecessor, attributed this disaster to the wrath of heaven at the murder of the prelate, and advised, as a penance, the removal of all the inhabitants to a site where a new city could be built, free from the everlasting stain of sacrilege and murder. Early one April morning, the whole population, en masse, left the old city, and, headed by the governor and bishop on horseback, marched to the new sitc, some twenty miles distant.

Religious zeal seems to have been accompanied, on this occasion, by more than the ordinary amount of far-sightedness and common-scnse. Not only did the worthy bishop, by this means, impress upon the people of Leon the enormity of the crime committed by the young Contreras sixty years before, but he succeeded, also, in inducing the whole population to undertake the founding of a new city out on the plains, where the danger of a volcanic eruption and disaster would never be present.

The position of modern Leon, on the highway to the interior highlands and the rich agricultural lands of Matagalpa, is mainly responsible for the present size and prosperity of this city, which has a population of over 60,000, nearly double that of the capital. It is a busy town, for this portion of the continent, and has several fine buildings, although by far the largest majority are one-storey dwellings, without architectural beauty. Its streets are straight, and fairly level, but the old-fashioned cobbles with which they are paved render walking anything but pleasant. In the dry season, the roads are usually thickly covered with loose dust, which is continually being whisked into the air in clouds, making the atmosphere hot and stifling. In the wet season, deep ruts in the cobbled pavements drain much of the water from the roadway, but at the 
beginning of the rains, a preponderance of mud is everywhere apparent.

Notwithstanding these disadvantages, however, Leon has its attractions. The people are hospitable, goodtempered, and especially well disposed towards foreigners, of whom there are a good many.

There is a certain picturesqueness in its quaint streets, tropical foliage, and barefooted mozos, which renders it peculiarly attractive.

Like Guatemala City, with its annual Fêtes of Minerva, Leon is famous for its processions in the Semana Santa or Holy Week. The road taken by these religious processions, leading across country to the adjacent old Indian town of Subtiavia, is covered with sawdust of many colours, cleverly formed into most elaborate patterns, like a huge and continuous carpet, adorned with beautifully scented flowers. The overhead decorations comprise arches, with long lines of fluttering flags, paper streamers, and banks of frangipani and wild roses.

The cathedral of Leon, a massive and costly building completed in I743, is one of the largest in Latin America. It covers an entire square, and its front extends the whole width of the grand plaza. Architecturally its somewhat heavy bastard Renaissance style, with a lofty nave and two towers, ornamented with festoons, wreaths, and Ionic pilasters in pairs, will not arouse enthusiasm, but structurally it certainly does credit to its builders; for it has stood far more than a century and a half a succession of storms and earthquakes that would have brought long ago to ruin any but the strongest pile. About the middle of last century, one of the towers was cracked from top to bottom by lightning. The uses of the building have been other than ecclesiastical. It has been a fortress-a strong one-and has sustained more than one cannonade and bombardment. In I8I3 thirty pieces of cannon thundered from its roof, and on 



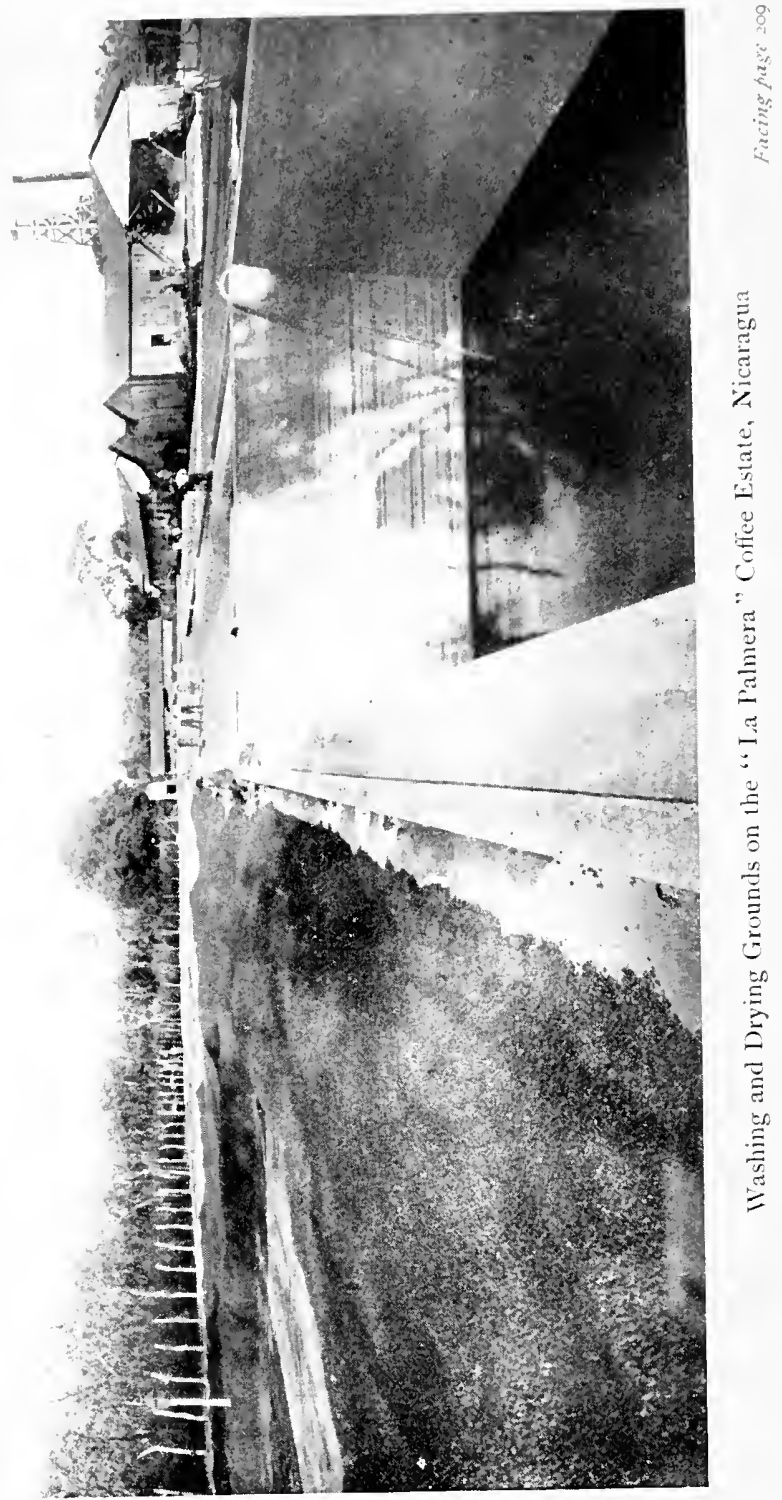




\section{COUNTRY, CITIES, AND PEOPLE 209}

the east wall the curious visitor will find many a mark of shot. Once the cathedral of Leon was the home of such vast wealth that its ornaments were a proverb in Spain itself ; but its days of glory are done, though it still contains some fine statues, oil paintings, and antiquities.

Not wholly without reason have certain writers reviled Central American architecture. Personally I pretend to no enthusiasm for it, though, when I quote Boyle on the subject, it is rather for a smile at the spirited freshness of his attack, than with any intention to endorse his judgment. Boyle, oblivious of grammar, goes at it vehemently: "In vain is the heavy façade built up between two square towers. In vain is a big round window pierced through the centre, like a gigantic $\mathrm{O}$ ! of disgust. In vain is whitewash and stucco besomed in, and windows, round and square and oblong, disposed in the intervals. Notwithstanding these adornments, the effect is incredibly poor and ugly. Would he [General Henningsen] had blown them all up, beginning with that colossal altar of deformity, the Cathedral at Leon."

From its roof is obtainable one of the loveliest views imaginable, from the nine volcanoes of the Marabios to the Pacific, a rim of silver on the distant horizon, and at your feet, embowered in green foliage, the tiled roofs and fair gardens of Leon. In the markets of Leon you may purchase, very cheaply indeed, almost every known fruit and vegetable, including water and marsh melons, pineapples, oranges, pomegranates, plantains, bananas, beans, maize, and small potatoes ; you may purchase, too, in the streets, from lightly clad Indian girls, those dulces (sweets) of which the Spanish ladies consume so many between their two meals a day. If you do not eat sweets, you may, perhaps, if you have an ear for music, be well repaid by the "Mil gracias, scñor," that accompanies so melodiously the passing of the coin.

The Indians of Nicaragua, the predominant race in 
number, are a docile and inoffensive people, singularly mild and gentle both in expression and manner. Unobtrusive by nature, they seldom speak to you unless first spoken to, and are kind and hospitable, though fine fighters when the necessity arises. It is my sincere hope that the necessity will never again arise.

The barbarous Spanish method of executing the Indians by means of dogs, as practised in the public squares of Leon in 1528, was somewhat as follows:-

"Each cazique [said Oviedo] was armed with a stick, and told to defend himself against the dogs, and to kill them if he could. Five or six young dogs were first set upon them, which their masters wished to train, as they were yet without experience. They ran baying around the Indian, who easily kept them off with his stick; but the moment he thought himself conqueror, a couple of mastiffs, or well-trained hounds, were set against him, who threw him in a moment. The other dogs then fell upon him, biting and choking him, tearing out his entrails, and devouring him as it were. In this manner the eighteen were soon disposed of. When the dogs were satiated, the dead bodies remained in the same place, it being forbidden to carry them off, under penalty of being served in like manner."

In the autumn of 1824 , Leon, during one of the revolutionary wars, suffered a siege of one hundred and fourteen days, which, when the city had been carried by assault, was followed by one of the bloodiest massacres in the history of America. Quarter was given to none, neither to the feeble old men, nor to the unborn child, nor to women, whose blood flowed in a crimson cascade down the church steps. In a political quarrel men murdered their own sisters and nieces. Every tie, whether of affection or of blood, was cut with the sword. Lamentable is it to know that, as Byam has well pointed out in his "Wild Life in the Interior of Central America," almost all Spanish American revolutions are brought 


\section{COUNTRY, CITIES, AND PEOPLE 211}

about by a small fraction of the population. 'Tis a thousand pities that the general public endure it so sheepishly. If, instead of allowing themselves to be shorn by a minority of rascals, they had resisted, and backed that resistance by arms, revolutions in Central America would have been much less frequent. But the law-abiding majority, all the world over, is extraordinarily patient, as witness the behaviour of the bourgeois during the French Revolution, and of our own lower middle classes during English industrial disputes in which the nation has been held up to ransom. Revolutions, throughout all history, have afforded splendid opportunities for, and sometimes have been wholly the work of, adventurers, upstarts, and degenerates of all classes, on the look-out for plunder. Often enough the reason for these émeutes is as mysterious as that given in the refrain of the old song:

\section{"Friends and foes,}

To battle they goes,

But what they all fight for, nobody knows."

Only the very latest form of revolution, such as that in Mexico, which resulted in the overthrow of President Diaz, is, at the bottom, commercial. Rumour has it, perhaps not untruly, that that movement was financed by an American Trust. In such instances, the refrain quoted above does not apply. What they fight for everyone knows.

The modern Latin American president, by the way, is a very charming gentleman; affable, courteous, and, as a rule, well educated, though to such a man as Rafael Carrera, who would solemnly read, holding it upside down, a note handed to him by a foreign diplomat, the last adjective cannot truthfully be applied. Nothing could be more delightful than an interview with one of them; you come away much impressed with their gentleness, and kindness. Later on, perhaps, you will 
discover that the velvet glove can be discarded for the steel gauntlet ; that the hand that can clasp another so warmly in friendship can also strike terribly, if need be. If need be-there you have the secret of it. Sooner or later it has to be done. Then it is done.

Not long ago, a plot was discovered against the life of one of the presidents of a Latin American republic. He was warned that the assassins, who were known to the informer, would land in his country by a certain steamer. On the arrival of that steamer off the coast, a small boat, containing armed men, went out to meet it. Several of its passengers were transferred to the small boat, which then put off for the shore. That boat safely reached harbour, with the same number of persons on board as had left the harbour. Subsequently the president of that republic wrote to his informant thanking him for the warning, and adding: "The persons mentioned in your despatch did not land." They have not yet landed!

Of the many interesting stones and ruins, of the curiously carved pagan idols, altars, and shrines, as well as of Christian churches, that abound in the neighbourhood of Leon, we have no space in which to speak here ; moreover, their interest and details are rather for the antiquary and archæologist than for the general reader; but we would earnestly advise all visitors who can spare time, to wander awhile in those silent places, such as are to be found in the forests around Subtiavia; where the wild vines creep lovingly about ruined walls, where bats and birds wing ceaselessly around falling columns, and where, instead of marble pavements, the brilliant flowers of nature deck the tangled naves, and jewel the deserted altars of the Most High.

Away some miles distant, to the south, on the shores of Lake Nicaragua, stands Leon's rival, the city of Granada. Even though little of the old Spanish town survived the burning by Walker, in 1856 , it has an oldworld air, and one observes in its population much of 


\section{COUNTRY, CITIES, AND PEOPLE 213}

the noblesse oblige of the Spanish regime; for Granada is still the Conservative stronghold of Nicaragua, and many of the best and most wealthy families of the country reside within its area, or in the surrounding districts. It is, at the same time, one of the most picturesquely situated towns in the state.

Standing as it does, near the shore of that small inland sea, Lake Nicaragua, Granada is refreshed, in the hot season, by the breezes from the water ; its luxuriance of tropical trees, fruit, and flowers, adds considerably to already great natural charms.

The giant volcanoes, Momobacho and Masaya, three leagues distant on one side and the other, frame in this peaceful city. Rugged and bold in outline, they cleave the blue sky with frowning crests, and cast dark shadows over the broad bosom of the sunlit lake.

Half-way between the town and the lake stand the ruins of Guadaloupe church, in which, after firing the old Spanish town, Henningsen made his last stand. When reinforcements arrived, and he escaped by the lake, he left fixed to a stake a paper on which were written the significant words: "Here was Granada." Only three buildings, out of the hundreds which composed this city, remained uninjured after the fire.

All the country around Granada is very volcanic. The town is half encircled, and two of its suburbs are cut off by, an immense ditch, of volcanic origin, which in many places reaches a width of roo feet and a depth of 60 feet. Along this way came Walker with his I75 filibusters to carry Granada by storm and raise the siege of Guadaloupe church. It was a desperately plucky deed. To enter that place in the pitchy darkness of midnight, to face the danger of falling rocks, deep morasses, and the still greater danger of almost certain discovery, when every man would have perished inevitably under a rain of earth and rocks hurled down on him from above, was the 
venture of a hero. And it succeeded. The filibusters scaled the precipice; then, dashing down the main street, they stormed three barricades, forced the retrenchments of an enemy vastly their superior in number, drove them from the town, and rescued General Henningsen and 200 defenders of the ruined church! It was a good coup de main.

The fruit market, in modern Granada, is, perhaps, one of the sights of the city, as is also the beautifully decorated interior of the cathedral; but it is in the surrounding country, or on one of the fresh and green islands far out on the placid waters of the lake, that the real charm of Granada must be sought.

Wonderful are the beauties of Lake Nicaragua. Sailing over those blue waters, you may see, with marvellous distinctness, and apparently quite close to you, though in reality you are thirty miles distant from the shore, the majestic volcanoes of Ometepec and Madeira rising clear and cold against the sky, while the slowly moving clouds, veiling the summits, throw gliding shadows upon their giant sides. Directly in front, distinguished by the towering edges of its vast and rugged crater, rises the extinct volcano of Momobacho, at the foot of which stands the ancient city of Granada. Above the forests that fringe the shore rise bare conical hills of a greenish-yellow colour-cones of scoriæ, sand, and ashes, silent witnesses of many a past eruption.

Upon the shores of this vast lake, the surf, in windy seasons, thunders, as upon an ocean beach. The natives, who are bold in the water, have a very effective way of landing passengers. They bring the boat as far inshore as they dare, then three or four of them leap overboard, and, with their heads and shoulders out of water, invite the passengers to "get on." The victim sits on the head of one, puts his legs on the shoulders of another, and so, finally, in a more or less moist condition, is deposited on shore, amid the acclamations of a native 


\section{COUNTRY, CITIES, AND PEOPLE 215}

audience. An evening visit to the shore of the lake at Granada is a sight never to be forgotten.

"We descended to the shores of the lake just as the sun was setting, throwing the whole beach in shade, while the fairy : Corales' were swimming in the evening light. The shore was tenfold more animated than when we landed the previous day; men on horseback, women on foot, sailors, fishermen, idlers, children, and a swarm of water-carriers mingling together gave life to the scene; while boats and graceful canoes, drawn up on the beach, bongos rocking at their anchors outside, the grim old fort frowning above, and the green border of trees with bars of sunlight streaming between them, all contributed to brighten and give effect to the picture. We rode up the glacis of the old castle, through its broken archway, into its elevated area, and looked out beyond the broad and beautiful lake, upon the distant shores of Chontales, with its earthquake riven hills, and rugged volcanic craters. Their rough features were brought out sharply and distinctly in the slanting light which gilded the northern slope of the gigantic volcano of Momobacho, while its eastern declivity slept in purple shadow. We were absorbed in contemplating one by one these varied beauties, when the bells of the city struck the hour of the 'oracion.' In an instant every voice was hushed, the horseman reined in his stead, the ropes dropped from the hands of the sailors, the sentinel on the fort stopped short on his round, even the waterjars were left half-filled, while every hat was removed, and every lip moved in prayer. The very waves seemed to break more gently on the shore, in harmony with the vibrations of the distant bells; while the subdued hum of reverential voices filled the pauses between. There was something almost magical in this sudden hush of the multitude, and its apparently entire absorption in devotion, which could not fail deeply to impress the stranger witnessing it for the first time" (SQUIER). 
Many of the islands on the lake are very beautiful. The patches of cultivated ground, relieved by a dense green background of plantains and kingly palms, are crowned by the picturesque cane huts of the natives. Among the foliage, flocks of noisy parrots and parakeets chatter and squabble; inquisitive monkeys scurry among the vines, and long-legged cranes meditate by the water's edge. By the shores of the miniature harbour, an Indian woman, naked to the waist, with long black hair streaming over her shoulders, is washing clothes. Such is a typical scene in this Mahomet's paradise.

Thomas Gage, who crossed Nicaragua in the middle of the sixteenth century, writes, in $\mathrm{I} 54 \mathrm{I}$, the following interesting description of the lake:-

"It has a large number of islands, of some extent, covered with flocks and precious woods. The largest is eight leagues in circumference, and is inhabited by Indians. It is very fertile, filled with deer and rabbits, and named Ometepec, which signifies two mountains. The mountain on this island towards the east is lowest ; the other is so high that its summit is seldom seen. When I passed by this island the atmosphere was very clear, and I could easily see the summit. I passed the night at a farm belonging to a gentleman named Diego Mora, situated on the mainland, near the island. The keeper told me that during the two years he had been in that place he had seen the summit but once, because it was always covered with clouds.

" On the south side of the great lake is a smaller one, called Zongozana, which is separated from it by a flat shore, but one hundred and fifty paces wide. It is formed by rains which fill it up in the rainy season, and as it is higher than the great lake, its waters bear away the sand, and empty into it. This laguna then becomes filled with alligators and all kinds of fish. But during the summer it nearly dries up. The 
Indians then kill with clubs great numbers of alligators and fish. ... I visited it in the latter part of July, I529, and there was but little water in it. The farmer whom I have mentioned had many logs, which fed on the fish which they caught there, and were so large that they looked frightful, the more so, because they had the smell and taste of fish. For this reason they are now kept away from the laguna, and only allowed to approach to drink.

"In this vicinity there are numerous black tigers, which made great havoc in this farmer's flocks. He had some excellent dogs, which had killed many of these tigers; he showed me one in particular that had killed two or three. The skin of one of the animals, which he showed me, was black, like velvet; this kind is more ferocious than the spotted variety. He said he would not take a thousand dollars for his dogs, for his pork was worth a thousand, and without the dogs the tigers would have destroyed them all."

Lake Nicaragua, ideal though it be under favourable conditions, is a very dangerous sheet of water. Calms are not so frequent as the tempests or tornadoes that have capsized many a good vessel upon its waters, or wrecked them upon the lake's shores. Storms, gathering behind the volcanic peaks of Ometepec and Zapatero, swoop down with whirlwind violence from half-a-dozen points at once, until, in a few minutes, the peaceful waters are lashed into intense fury. Few seas or oceans are to be compared with it for violence and treachery.

The great variety of fish, including sharks, in the lakes of Managua and Nicaragua, offer a ready employment to the people living on their shores. It was formerly supposed, owing to the ebb and flow of the water, that the lakes communicated with the sea, and were tidal. This, of course, is a mistake, due, as Squier has pointed out, to the extraordinary regularity 
with which the prevailing wind in Nicaragua, the northeast trade wind, blowing most strongly at noon and in the evening, heaps up the waters upon the western shores of the lakes.

Fascinating beyond description are the walks to be had, down some of the paths by the lake-side. Through bush and brier you wend, beneath gigantic, vinedraped trees, down into dark ravines, where the sun's rays never penetrate, over grass-covered ridges, gemmed with fragrant flowers, beside clusters of magnificent trees, between whose trunks, soaring like Gothic columns, the eye catches here and there a glimpse of the shining lake, its distant shores and islands. To walk thus in the cool of the morning, scaring the noisy parrots from your path, the startled deer from her green coverts, is to equip yourself with memories of physical delight that shall pass only with your life. The nights, even, spent drowsily by the camp fire, to the music of "carreteros" laughter, and snatches of song, as they play cards by the light of the flickering flame, compensate for some of the tortures of the day, among which not the least are those plagues of Nicaragua-the myriad insects that lie in wait for you upon every leaf.

So much for the inland waters-now for the Pacific ports.

The Pacific ports of Nicaragua are San Juan del Sur and Corinto. About half-a-century ago, the former was one of the most important towns in the state, as it lies at the Pacific end of what was then the transit route by land and water through the country, and, with Realejo, was the emporium for the oversea commerce of Leon and Granada; but when, in later years, Corinto was chosen as the Pacific terminus of the railroad, on account of its deep land-locked harbour, San Juan del Sur sunk to a position of only secondary importance, while each year saw an increase in the 


\section{COUNTRY, CITIES, AND PEOPLE 219}

size and activity of its rival, until at the present time, Corinto, although principally a wooden town, far exceeds in population and commercial importance the quiet little port of San Juan. The population of Realejo, which never exceeded rooo, has now declined to less than 500; and its trade and prosperity have likewise departed.

Corinto is a town of some 1500 inhabitants; but it possesses few attractions, as the houses are all one or two storey, bungalow-like structures with redtiled roofs; and the streets-if such they can be called -are only beaten tracks leading past the scattered and uneven dwellings.

If the town of Corinto lacks attractiveness, the same cannot be said of the surrounding seaside, river, and country scenery, which, in places, is almost indescribably lovely. The "Calles de Venezia," the name given to a multitude of beautiful little islets in the riverestuary of Corinto Bay, is perhaps one of the most beautiful tropical river scenes in the whole of Central America ; while the growth-covered shores of Corinto Bay, and the scenery up the river to Realejo, afford a tout ensemble of luxuriant verdure, with tall palms waving in the Pacific breeze, equalled in many parts of the tropics, but seldom or never surpassed.

Rivas, the only other town of importance on the Pacific side of Nicaragua, lies in close proximity to quiet little San Juan del Sur. It is a town possessing both a stirring history and an active commerce. Many were the fights which took place here, both before and during the Walker Raid. Its position on the road, between the port and the transit line, gave it a strategic importance that not only caused it to become the centre of the revolutionary war of I855-I860, but also gives, at the present time, a commercial activity denied to larger towns in less advantageous positions. 
The town of Rivas has a population of about I4,0oo, but the large number of flourishing cocoa plantations in the surrounding country causes the commerce of this town to be greatly in excess of what one might suppose from its size. About Rivas little can be said of interest, for although it has its attractions, among which must be mentioned its historic plaza, held for so long by Walker and his followers against enormous odds, it is a typical Central American town, with one or two commercial thoroughfares, and a large number of open, tree-bordered roads and spaces.

The journey up-country, from the black, volcanic soil of the hot, Pacific coast-lands, where one sleeps with little covering, save the mosquito net, to the green coffee-bush-covered hills and valleys of the interior highlands around Matagalpa, where blankets, for night use, become quite necessary, gives one much the same feeling of returning vitality as does a breath from the broad Atlantic, after voyaging on the upper reaches of the mighty Amazon. It is mainly on account of its healthy altitude that the town of Matagalpa has such a thriving trade, and so considerable a foreign colony.

Before crediting the town of Matagalpa with what, in fairness, must here be accorded to it, we may well say something of the journey to be got through before arriving there. Three defincd roads lead to this mountain city-one from Managua, the capital, via Savannah Grande; one from $\mathrm{La} \mathrm{Paz}$; and one from Leon; but there are, at present, no railway connections, although one has been projected for many years, and it is therefore necessary to go on horse or mule back and to equip oneself with hammocks, bedding, and pack animals. In the wet season these tracks are almost impassable, by reason of mud; and in the dry season, dust flies up in clouds from the beating hoofs, making it distinctly advisable to keep at a respectful 


\section{COUNTRY, CITIES, AND PEOPLE 221}

distance behind the traveller next ahead of you. If one starts from Leon in the dry season, soon after the sun has passed meridian, the ride, before nightfall, is not altogether unpleasant, although the dust is decidedly trying. The way leads for many miles over flat country, with scarcely a living thing in sight, save, perhaps, a few lizards or a snake. An occasional patch of low scrub or clump of trees waves in the faint breeze of early evening.

No towns, nor villages even, break the monotony of the vast stretch of lonely plain ; and only occasional haciendas enable food of a kind to be obtained. At Las Montes the plains break into clumps of forest, gay with parrots, and alive with monkeys; then, after crossing and recrossing the Jicaral river, several times, the town of the same name is entered, and, as the sun sinks beneath the western horizon, stillness and darkness creep slowly over the scene.

Moonlight in Nicaragua is almost equal to daylight in Europe. The surrounding country is bathed, at first, in a pale, golden light, changing, as the moon rises, to a bright silver, with every tree sharply defined against the star-spangled, blue vault. When the Cuesta de las Tenajas is passed, the ground begins to rise, trees become more numerous, and their dark shadows cover much of the earth. The air is cool, and the riding pleasant, but the horizon is obstructed by the ever-nearing mass of rock, forming the volcano; Momotombo, the lofty crater of which is sharply defined against the luminous blueness of the sky. The country now becomes more cultivated; wide pasture-lands take the place of lonely desolate plains, and the homely cornfields send the thoughts of the traveller whirling back to civilisation; but the scene passes with the night, which, by the way, is often spent at the cattle ranch of Progreso.

At Real de la Cruz begin the great cattle plains of 
Nicaragua, known as Llano de Sabeco. The sun is up, and with it the cowboys, for hereabouts are numerous ranches, some of which are shielded from view by the clumps of fine cedars and other trees. There is, on these plains, much to remind one of Mexico, and an atmosphere akin to the old Wild West of romance; for large herds of cattle roam over these prairies, which have a more temperate climate than the lowlands of the coast.

The most difficult portion of the journey is commenced after these plains are partly traversed. The road zigzags up and around low foothills, steadily increasing in height, until an altitude of 2000 to 3500 feet is attained.

Then, after a steady climb of many hours, the top of Mount Matagalpa is reached. The town lies in the hazy valley beneath, and the surrounding hills are covered in green coffee bushes and wild growth. The descent into the town is easy, and a bath to remove the caked dust and perspiration becomes the primary object of most white travellers, after covering the forty leagues from Leon.

Between Matagalpa and the Atlantic coast lies the bulk of Nicaragua's unexploited land - a vast expanse, deserted though fertile, and for the most part well watered, and not altogether unhealthy, though malarious in certain districts. For the cultivation of tropical fruits and trees, such as rubber, there could scarcely be a better country, or one where concessions of land, with perfect titles, are more easily obtained by foreigners.

About this wide and almost unknown country it is impossible to say much here. A journey across it reveals but a tithe of its possibilities. The deterrent feature, at present, appears to be the lack of transport facilities, although it is crossed by several navigable rivers. 


\section{COUNTRY, CITIES, AND PEOPLE 223}

The population of this section of Nicaragua is almost entirely native, and is very scattered ; in fact, it is scarcely an exaggeration to say that it is not populated at all, for one may ride for hours without seeing a single human being, although occasionally a few native palm-thatched huts, a lonely mine, or a plantation are passed.

The descent from the highlands on the Atlantic side is not nearly so precipitous as it is on the Pacific coast ; consequently the change of temperature, which, around Matagalpa, shows a range of from 60 to 85 degrees during the year, is more gradual, but the climate of the Atlantic slope is decidedly damp and tropical.

The only town and port of any importance on this coast is Bluefields, the old capital of the kingdom of Mosquititia, which is now a thriving port for the shipment of fruit, of which bananas form the bulk.

This town, and the surrounding coast, became decidedly prosperous after the suppression of piracy and lawlessness which was at one time rife. Many valuable plantations sprang into being, and the natives turned from guerrilla warfare to agriculture, when the British supported the Mosquito king; but when Zelaya annexed it, with the support of the United States, the port duties of Bluefields were increased many times over; a monopoly of sailing rights over the Escondido river-the great commercial highway into the surrounding country-was granted to a steamship company, whose rates became prohibitive; and the discontented planters, many of whom were either Europeans or North Americans, seeing their hardly won success being completely neutralised, twice revolted, but were defeated by Zelaya's forces. The early progress and prosperity of Bluefields and the Atlantic coast then began slowly to disappear; until, at last, the indignant planters, upon whose shoulders additional burdens were continually being 
placed, joined with General Estrada and his force, which was drawn from all parts of the country, in a determined fight against Zclayaism in 1909 and I9Io.

Blueficlds, once the centre of this successful insurrection, is now settling down to take advantage of the new era, which, if appearances be correct, should prove a prosperous one.

This Bluefields, typical Central American town, built mostly of wood, is one of the most healthy places on the Atlantic seaboard of the isthmus, and its shipping trade is far larger than that of any other Nicaraguan port on this coast. The chief imports are salt meats, rice, machinery, clothes, and hardware, whilst the exports consist mainly of fruit, rubber (wild) and gold. The usual weekly shipment of bananas amounts to nearly twenty thousand bunches, a figure that will be greatly exceeded when the country bordering the Escondido river has been properly opened up. The bulk of the fruit shipped from this port goes to the United States.

The establishment in Nicaragua of the gold standard was commenced in 1912. The new units are: the gold cordoba, divided into Ioo equal parts; the silver cordoba, and various silver and nickel coins of small value. 


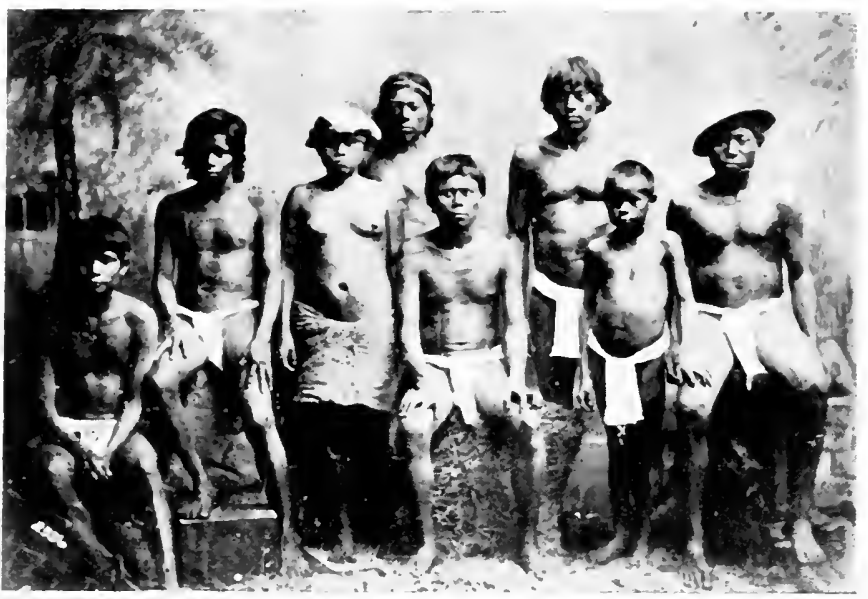

A Group of Indians, Central Costa Rica

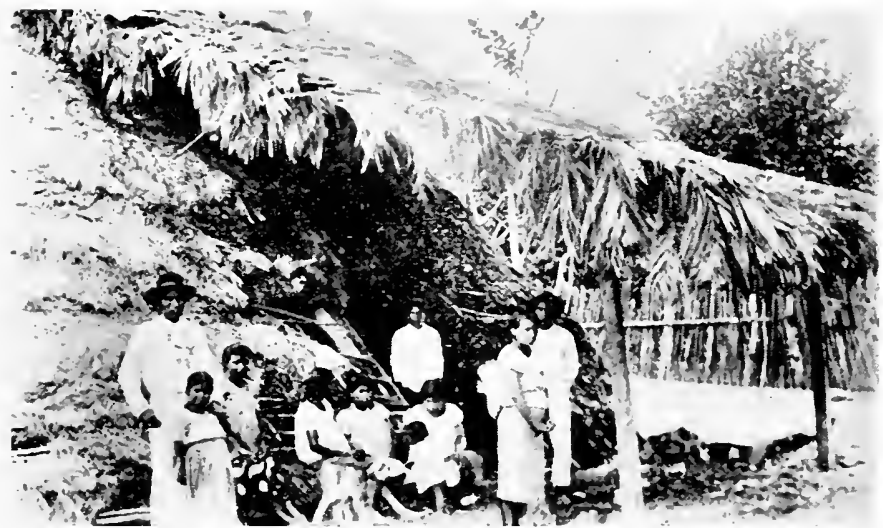

An Indian King and his Family, Costa Rica

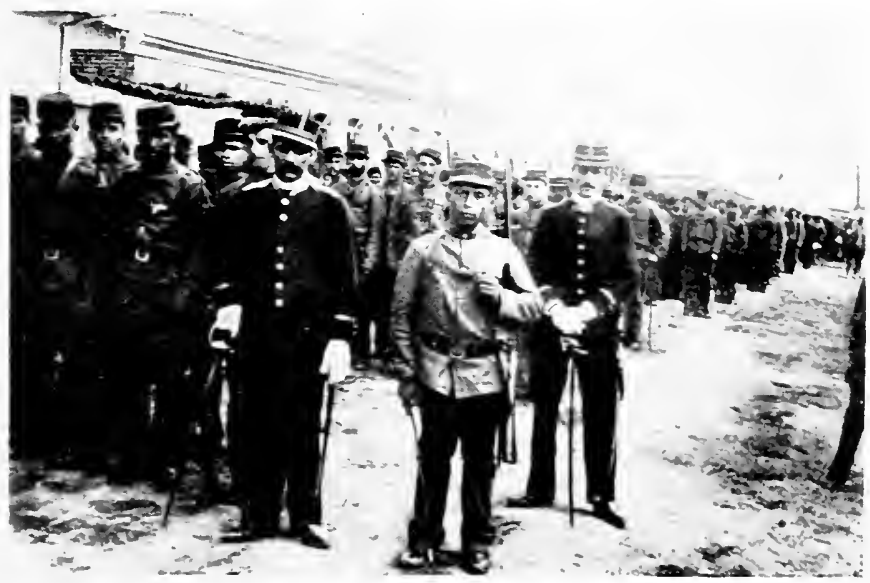

Costa lican Infantry 


$$
\text { . }
$$




\section{CHAPTER IV}

\section{SOME CHARACTERISTIC FEATURES}

In this chapter, which threatens to prove somewhat discursive, I propose to touch upon a few distinctive features of Nicaragua, from its villages and volcanoes to its women and wild beasts, all of which are, in their several kinds, characteristic.

Some of the villages of Nicaragua are of extraordinary beauty; none more so than Nindiri, whose musical name (Nienda, water, and Diria, mountain) tells us, in an ancient, almost forgotten tongue, that she still slumbers between the lake and the hill, beneath the evergreen waving domes of her tropical forests. This little Indian village may be said truly to surpass, in scenes of quiet loveliness, anything that has ever been fashioned by a traveller's fancy. Oranges, plantains, and tall palms, with their many-coloured fruits gleaming gold and brown between the leaves, calabash-trees with green globes strung on every limb, embower the cane huts of the natives. Beneath the trees Indian women, naked to the waist, are spinning snow-white cotton, while, between the branches, rays of sunlight dance and quiver upon the smoothly beaten ground, whereon a dozen naked urchins are rolling in play. How much better to live in semi-idle luxury - for Nature is here a bounteous mother-in this dreamy Arcadia; this ancient home of the caciques and their barbaric courts, than to fester away one's life in the reeking, disease-stricken slums of a great English town.

Mr Boyle, who had a strong strain of poctry in his 
composition, was inspired by Nindiri to the following rhapsody :-

"One cannot inventory Paradise. In my memory stand groups of dusky deep-shadowed huts, pierced with red gleams of firelight, and overhung with shcets of blossom. Even yet our hearts can fecl the softness of that enchanted foliage, and the thick perfume of its flowers. Tall palms stand out keen and black against a pale blue sky, bearing aloft their polished crowns which glitter like a range of frozen fountains. Ay de mi! Where can I find words? As we look, a vision forms before us of what life might be in that unearthly village, and then - and then a pig runs across the moonlit road to remind us of what it is. Yet I keep my faith in Nindiri, for I had not conceived, in the whole world together, such fairy loveliness as she displays."

Not far from Nindiri is the great volcano of Maraya, situate in the mal pais, the bad country, an immense field of lava which has flowed down from the mountain, for nearly twenty miles, towards the great lakes of Nicaragua and Managua. It has the appearance of a vast plain of cast iron, newly cooled, black and forbidding, or of an ocean of ink, suddenly frozen during a storm. Early chronicles give some good accounts of this "Inferno de Maraya," or hell of Maraya, as it is called. Orviedo, who visited it in I529, says :

"It seems to me that none of these volcanoes (Vesuvius, Etna, etc.) are to be compared with that of Maraya, which, as I have said, I have seen and examined myself." After describing his ascent, and the crater, he continues: "I beheld at the bottom of the second crater a fire, which was as liquid as water, and of the colour of brass. This fire appeared to me more violent than any I had ever seen before, and entirely covered the bottom of the crater. From time to time this matter rose into the air with great force, hurling large masses to a height of many feet, as it appeared to me. Sometimes these 


\section{SOME CHARACTERISTIC FEATURES 227}

masses were arrested on the sides of the crater, and remained there, before becoming extinguished, time enough to repeat the credo six times, and then looked like the scoriæ of a forge. I cannot believe that a Christian could behold this spectacle unmindful of hell and unrepentant of his sins; particularly while comparing this vein of sulphur with the eternal grandeur of everlasting fire which awaits those who are ungrateful to God!

"Towards the middle of the first crater, a large number of parroqueets might be seen, circling round, of that species having the long tails, and called jigaves. I could only see their backs, for I stood much higher than they. They make their nests among the rocks, above the spectator. . . . Some persons have asserted that when the parroqueets are fluttering among these places, and one looks fixedly, he seems not to see fire but sulphur.... On the top of the volcano, on the eastern part, an elevation rises up, in which is an opening like to the crater but deeper. A smoke ascends through which it cannot be seen during the daytime, but which projects into the darkness a great light, uniting itself to that proceeding from the larger opening. . . .

"I have heard the cazique of Tendire (Nindiri) say that he has often gone, in company with other caziques, to the edge of the crater; and that an old woman, entirely naked, has come forth from it, with whom they held a monexico, or secret council. They consulted her in order to know if they should make war, or decline or grant a truce to their enemies. They did nothing without first consulting her ; for she told them whether they were to conquer or be conquered; she told them also, if it was about to rain; if the harvest of maize would be abundant; and, in fine, all future events. And everything always came to pass just as she had predicted it would. On such occasions, a man or two, some women, and children of both sexes were sacrificed 
to her; the victims offering themselves voluntarily. $\mathrm{He}$ added that since the Christians came into the country, the old woman had appeared only at long intervals; that she had told them the Christians were wicked ; and that she did not wish to have any communications with the Indians until they had driven the Christians from their country. I asked him how they got below. He answered that formerly there was a road; but that the cavity had been enlarged by the caving in of the land around it, and then the path had been destroyed. I asked him what they did after their council with the old woman, and what was her appearance. He replied that she was old and wrinkled; that her hair was thin and erect; that her teeth were long and sharp as a dog's; her skin of a darker colour than Indians ordinarily have; eyes fiery and sunken; in short, he described her as like the devil, which she must have been ! . . "

Orviedo, who was evidently much interested in this mal pais, continues:

" The Indians often converse about this superstition, and many others; and in their books they represent the devil with as much leanness and quite as many queues as we are in the habit of painting him at the feet of the archangel Michael, or the apostle St Barthelemy. I am of the opinion therefore that they have seen him, that he has shown himself to them ; since they place his image in their temples, where they perform their diabolical idolatries. On the side of the crater of Maraya, there is a large heap of cups, plates, and basins, of excellent crockery, made in this country. Some had been broken, others were entire. The Indians had brought them there filled with all kinds of meat, and left them, saying they were for the old woman to eat, in order to please or appease her when an earthquake or violent tempest takes place ; for they attribute to her all the good and evil that happens to them." 



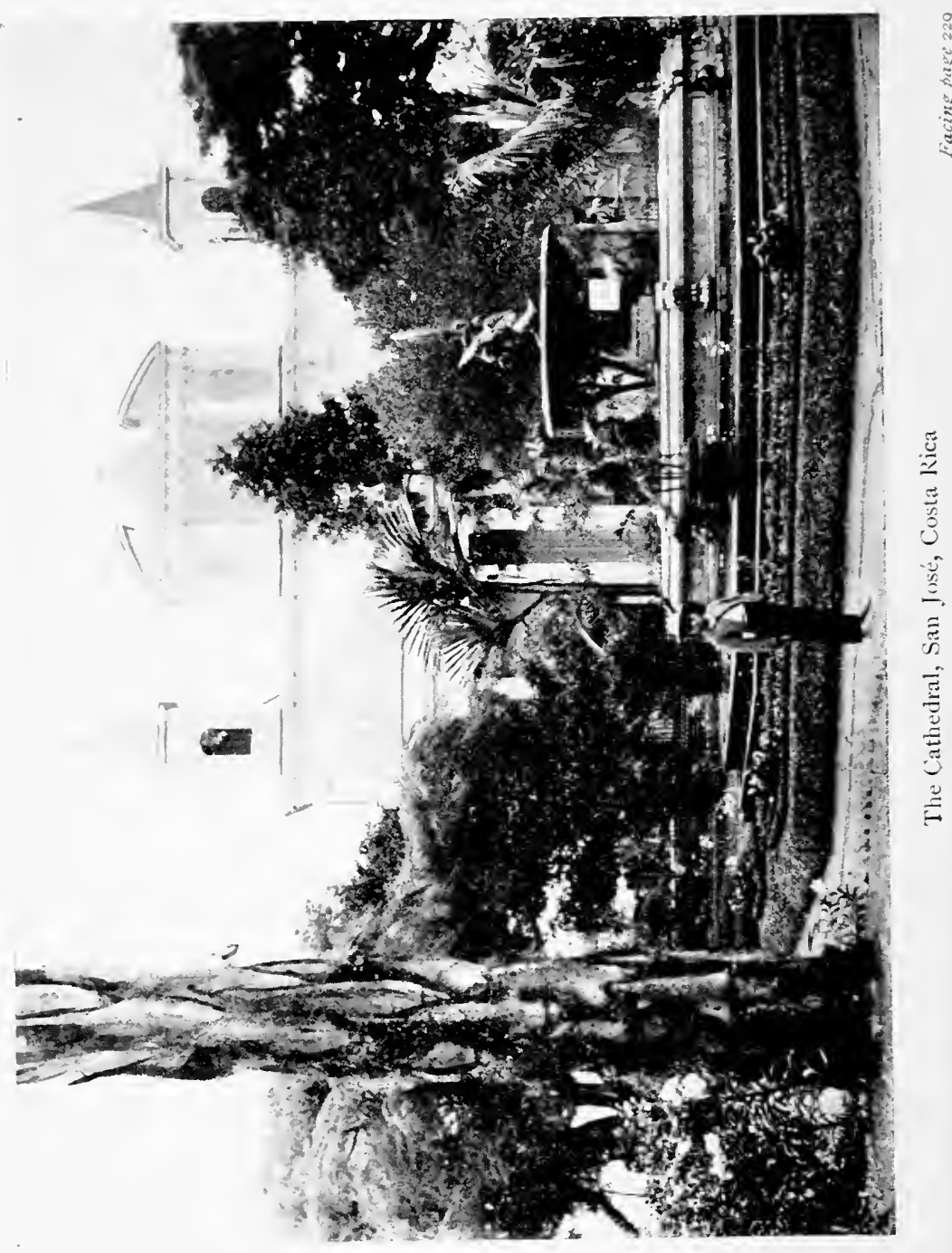




\section{SOME CHARACTERISTIC FEATURES 229}

In the volcanic area is the crater-lake Nihapa, which lies south-west from Managua City. For hundreds of years past it has been a centre of native worship and superstition. Even to-day here and there upon the tortured rocks that border it, and upon the vertical face of the cliff, you may see remnants of the piedras pintadas, native paintings, showing, frescoed in red and other colours, figures, and some of the symbols that from time immemorial, natives all the world over have chosen to represent human life, and the primitive human conception of its origin. Here you may see, for example, that most natural of all symbols, the coiled, plumed, and feathered serpent, called by the Indians "El Sol," the sun. The serpent has a dual significance, therefore; he represents the sun, the life and light bringer, and also sexual passion. $\mathrm{He}$ is the life-giver, too, symbolised in early Babylonian myth, and in the garden of Eden story of the Hebrew scriptures. Another symbol visible on these mysterious works is the Red Hand, emblem of the divinity Ka-bul, the Author of life and God of the Working Hand. Hundreds of other figures there are, including human forms, hieroglyphics, and representations of the sun and moon.

No wonder that such mysterious waters, held in the giant's cup whence once spouted fire, smoke, and molten lava, were of old highly venerated by the Indians, and even now are looked upon with awe and veneration. They will tell you that there are alligators in this lake, they will tell you, too, of demons, dwelling within its depths, who drag down to death swimmers who rashly venture upon its waters. These demons, no doubt, are the descendants of those foul spirits who of old provided for the fires of the living volcano, spirits in whose honour many a human victim has been laid hereabouts upon the sacrificial stone, and has felt the priest's knife cutting into his breast. Terrible were the gods of ancient America, especially in this land, where the 
natural forces vented themselves in the fearful cataclysms of cruption and earthquake.

Now that we have caught a glimpse of one, at least, of the ancient superstitions of Nicaragua, the reader may like to have a little more information concerning the Indians and their work.

One of their principal crafts is that of weaving.

The Indians are adepts at making very durable and charming cotton fabrics of various colours, of which the choicest is probably the Tyrian purple obtained from the murex shellfish found upon the Pacific coast of Nicaragua. The whole process is very interesting, as illustrating the extraordinary patience of many native races all the world over. A number of shells are collected on the seashore, and dried there; each shell is then taken up singly, and a few drops of the colouring fluid forced from it by gentle pressure. Into this each thread is dipped singly, and drawn out when it has soaked up enough of the liquid. The purple tint, which can be produced of any depth or tone, does not appear until the thread has been exposed to the air for some time. When its supply of colouring-matter is exhausted, the fish, little the worse for his adventure, is put back into the sea to recuperate. He will live to dye again.

The ancient Indians have left in Nicaragua, as elsewhere in Central America, many mysterious and deeply fascinating monuments of their civilisation, if that term be allowed.

The sculptured figures of the ancient Indian civilisation, or " painted monkeys," as the Nicaraguan Indians call them, may be divided, generally speaking, into those of amiable and those of horrible expression of countenance. The former are found upon the great cairns beneath which the dead lie buried, and are probably images of the dead. The second, often discovered in the neighbourhood of, but never upon, the 


\section{SOME CHARACTERISTIC FEATURES 231}

graves, probably represent supernatural beings, the deities of that natural, primitive rcligion of awe and terror, in which aboriginal man personifies the forces that from heaven alternately shine and thunder upon his devoted head. With their closed eyes, their distortions, their expressions of intense ferocity, they convey a profound impression of native skill in rendering still horror or terrific energy. Magnificently awful must the spectacle have been, when the midnight wind moaned among these temples, and the multitudes of their statues gleamed under the ivory moonbeams, or when the dawn played upon the painted banners, and the silence of the morning was broken by the wail of the pipes, the chanting of the priests, and the clang of the deer-hide cymbals.

You may stretch yourself almost unconsciously upon one of these fallen stones, and find your limbs falling into place, your head fallen back, your breast raised. Then you may realise with a shock, as others have done before you, that you are lying on a stone of sacrifice!

At Pentacole are some idols that Squier has well described :

"I succeeded in raising from its bed of centuries another idol of massive proportions, but differing entirely from the others, and possessing an extraordinary and forbidding aspect - the eyes were large, round and staring ; the ears broad and long, and from the widely distended mouth, the lower jaw of which was forced down by the hands of the figure, projected a tongue which reached to the breast, giving to the whole an unnatural and horrible expression. My men stood back, and more than one crossed himself as he muttered to his neighbour, 'Es el diablo,' 'It is the devil.' Upon that lapping tongue had been laid the palpitating hearts of how many hundred victims."

At Ixkeen there is a mound that has disclosed the remains of a house or temple, and several carved 
monoliths which formerly stood in front of the buildings, but are now, for the most part, decayed and overturned. One of these stones, magnificently carved, shows two Maya priests or chieftains wearing ornaments and elaborate head-dresses, facing one another, and holding ornamented staves in their hands. In the lower panels are crouching two prisoners bound with ropes, evidently captives of the gentlemen represented above. This monument probably cclebrated the conquest of the aboriginal inhabitants of the country, or, perhaps, a defeat of the northern invaders, who, as some believe, may have eventually overthrown the Maya civilisation.

The pottery of ancient Nicaragua- " as far superior to the modern production as is a Wedgwood vase to a flower-pot "-is especially curious and interesting. It was rarely worked on a wheel. The clay is brown and very tough, and the most usual diameter ten inches, with a height of four inches and a quarter. The patterns and ornaments are of an endless variety of odd markings in red and brownish-black, on a thick, yellowish glaze. All these markings no doubt had a significance which has not yet been discovered. The bottom is often decorated with a circulating ornament, and the interior painted in rings.

Whoso, after crossing Nicaragua, remains silent upon the topic that I now broach, shall not be forgiven. One word upon feminine Nicaragua.

The women of the pure Spanish stock are very fair, and inclined to embonpoint. Their dress, except in cases where they have adopted the stiff costume of their own country, is loose and flowing, leaving the neck and arms exposed. The dress is often white, with a skirt of flowered stuff, satin slippers, a red or purple sash wound loosely round the waist. A rosary with a little golden cross is often worn, and the toilet is completed by a narrow golden band, or a string of 
pearls round the forchead, sometimes binding the hair that falls luxuriantly upon the shoulders. And, indeed, the picture is worthy of so fair a setting. Oval face, regular features, large and lustrous black eyes, small mouth, pearly white teeth, tiny hands and feet, and a low, clear voice-such is the Nicaraguan lady-one might say, the Central American lady of pure stock. That the pure stock is rare, is a fact not wholly to be regretted by lovers of beauty ; for though, with intermixture of alien blood, the señora loses that transparent whiteness of skin, that indolent languor marking the lady of birth, she gains, with the tinge of alien brown, a peachlike bloom of complexion, an animation, a lightness and suppleness of figure that, if less dignified, and of lower caste, is to many more natural, and therefore more attractive than the pure type.

But, when thinking of the women, do not forget the Indian girl. Look at her there, coming towards usa full, lithe figure, walking erect as a grenadier beneath her heavy water jar. The long, glossy hair quivers to her tread; the alert, bright eyes sparkle as with impudent, musical voice she greets you: "Adios, cabelleros!" 1 You will be worse than a boor if you do not answer, with a smile: "Adios, mi alma!" 2 Go, lie in a hammock, sleep, and dream of her eyes.

In a hammock! There are some writers who would have us believe that the hammock is the country's curse, that it is responsible for the present comparative stagnation of the old active spirit of Spain; that the national ensign of Nicaragua should be a hammock. Another writer's description is not wholly untrue to-day :

"You enter a house-there is the owner swinging in his hammock, undressed, unwashed, not reading, not working, not thinking. There he lies, with his children beside him, backwards and forwards gently swaying in

1 "Greeting, gentlemen!". 2 "Greeting, my dear !" 
a half-doze . . in his head there is not an idea, whether of virtue or vice. As you enter the open doorway he looks up languidly, motions you to a parallel hammock, offers you a light for your own cigarette. . . It is not necessary to make a remark during your visit, you are at liberty to do so, but the answer is so drowsy, so softly impregnated with hammock, that conversation is not encouraged. Nicaragua lies in its hammock all day, and sleeps therein at night. When the general should be at the head of his troops, he is dozing in a gorgeous hammock of dyed grass ; when the army should answer the call of the general, the army is swinging softly in its ragged hammock of twine. The merchant has a hammock in his counting-house, and in the absence of customers he lies therein. The priest performs his parish duties suspended, like Mahomet, between heaven and earth. . . . To the hammock flies the lover or his lass in search of consolation; the disappointed candidate, the hen-pecked husband, the ruined storekeeper; all find their solace in the tender swing."

I had almost overlooked the animals, until the roar of one recalled them to me.

Have you ever heard the congo? Should you have on your conscience a crime unexpiated, or should you be merely unaccustomed to that beast, his voice is one of the severest nerve trials imaginable. You are standing at dusk in a still forest, whose thousand autumns have strewn the ground with a sound-deadening carpet of decay, so efficient that the sharp crackle of a stick scarcely breaks the silence. Suddenly the dark air quivers with a hoarse thunder that rumbles echoing from tree to tree. Louder it rolls, till all the air is rent with ferocious threatenings. Surely this is the roar of some awful monster about to fall upon its prey. Not so. It is the cry of a dingy and quite harmless baboon. ${ }^{1}$

${ }^{1}$ The congo, as a traveller has observed, is not uncommon in Europe. Only there he frequents the cities, not the woods. 
At the other extreme from harmlessness comes the tiger.

The tiger of Central America is, of course, no tiger at all, but the jaguar; while the beast known as the lion is the puma. The jaguar, a beautiful animal, grows to a length of four or five feet, and has strength and activity superior to that of any feline of equal size. He will attack without hesitation any defenceless animal, but, unless hard pressed by hunger or by hunters, will not always approach a man, though it is not fear that restrains him. When attacking a herd, however, there is one beast of which the tiger has to beware-and that is the guardian bull, some of which have emerged triumphant from many such battles; but, indeed, the tiger is generally too cunning to get in among the herd, which is always a danger to him; he prefers the safer method of taking the cattle singly. In some districts the native will himself go forth to battle against the tiger, armed only with a lance, on which the beast impales himself when he springs.

That, at least, is the theory, and generally it happens so; but sometimes the tiger forgets to spring with his paws wide apart, and crosses them, with the result that, instead of being impaled, he snaps the spear and bowls over the hunter. In that case the reserve man, armed with a sword or machete, engages the beast in battle over the prostrate form of his friend. If he wins, well and good. If he loses, or if he fails to face the beast, the friend's prostrate form will rise from the earth no more.

The puma, though "hyght" lion, is unworthy of his royal name. He is a sneak and a coward; though sometimes dangerous-as even cowards may be-and valiant when brought to bay. But he never seeks a battle. The danger of him is this, that, like Destiny, silent, unseen, unrelenting, he will follow a traveller's tracks, follow, follow, follow, with stealthy steps, 
waiting for the cover of night, and a slecping victim. That victim may wake to see two green, fiery eyes looking down into his-and then ... That is one of the horrors of a Nicaraguan forest.

One of the most impressive nature-sights to be scen in Nicaragua is that of an alligator seeking water, when the drying-up of his favourite pool has forced him to migrate. Rolling his great body caked with dry mud, silently waving his crested tail, the monstrous reptile, grey and colourless, wriggles on, rolling from side to side his hideous head. His path down the bed of the mountain stream, now long since dried up, is a winding garden of grasses and lilies, of young bamboo and feathery ferns, through whose tender webs he bursts, crushing down with awful strength the fairy palaces that deck his way. Now a rock bars his path. He goes straight at it. His tail rattles sharply on the stones, his iron chin rests a moment upon a ledge ; then a mighty claw spreads out; the fearful, stilly eyes peer up above the stone; the jagged ridge of the back arches itself above the shoulders. Death goes on his deadly way.

One word concerning that necessary beast, the horse. Horses and mules are still much used for travelling in the country, and great care is necessary in breaking them in, since their value depends more upon their training than upon their appearance. They are taught a rapid but exceedingly easy step, between a walk and a trot, called the paso-trote, which a well-trained horse will fall into at once and keep at from morning till night. Many a horseman has ridden them thus for thirty miles at a stretch, without a break, at a speed, on a level road, of about seven miles an hour. There are other gaits, such as the paso-llano, which is rapid, yet so easy and gentle that the rider may carry a cup of water in his hand, without spilling a drop, though moving at six miles an hour.

The saddle is usually of the Mexican type, with high 


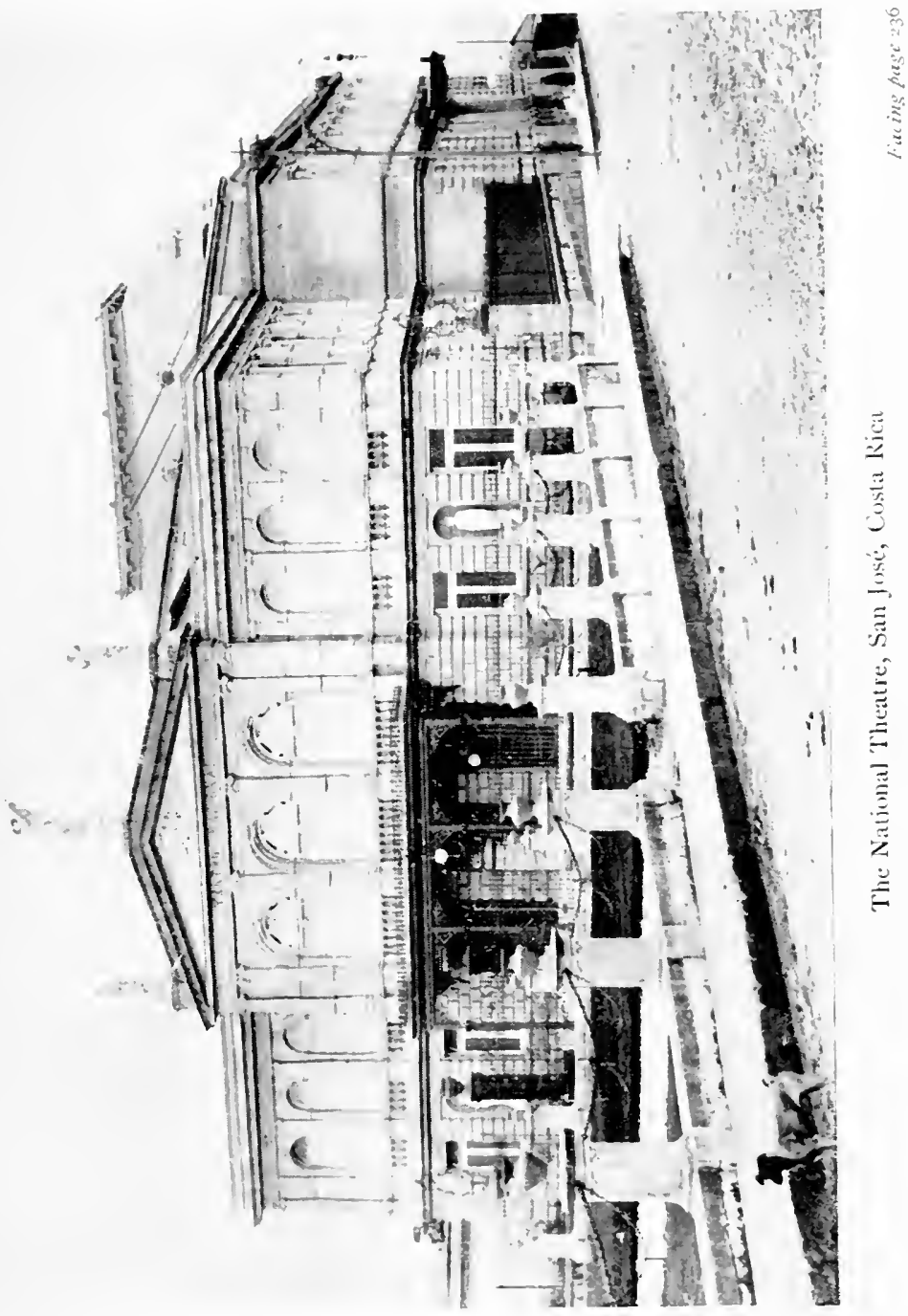



peak, over which the gaudily coloured sheep-skin (pillon) is thrown. Thus mounted, on a spirited horse, a pistol at his belt, his feet thrust into huge spurs, his sombrero cocked on the side of his head, your Nicaraguan "caballero" clattering through the streets, is prepared, one way or another, to conquer any man or any señora in all the land.

We will conclude this chapter with a reminder of the smaller scourges of Nicaragua-small only in size, but great in numbers and in power to annoy.

The American scorpion, a beast of a deep, dull, green colour, relieved with purple, is neither so large nor so dangerous as the Asiatic or African variety. That he can be unpleasant the following incident shows:-

"While standing in the doorway of a store, talking with the landlord, to us came limping $\mathrm{Mr} \mathrm{A}-$, a sixfoot-two American, belonging to the transit, who had slept in the hotel the previous night. When within hearing, 'Thunder,' cried he, 'you keep all the luxuries of this polished country constant on top, you do! Cast a tender glance at that !' He drew off his boot and shook a scorpion out of it. 'Kind o' rough that, ain't it now? That scorpion has been stinging me for the last two hours, as venomous as an old maid at a wedding breakfast. Nor he ain't got his coffin measure yet, though I've stamped him as flat as a skating floor!'

But the greatest curse of the country, the one horror inseparable from travel through Nicaraguan forests, and from night halts in remote inns, is the insect life. On halting for the night you may find yourself covered with agarrapatas or wood-ticks, which, lurking under every leaf, during the dry season, infest the forest in countless swarms. These pests bury themselves by their heads in the skin, and, kicking out their hind legs in a manner awful to behold, cause a maddening irritation, which is not relieved by pulling off the bodies, since the buried head only flourishes the more exceedingly, 
and if left in the skin causes an unpleasant sore. The smaller ones, hardly visible to the naked eye, are as bad as the larger; and there are few effective ways of removing either; the rubbing of a small ball of wax over the body, or the application of a few drops of oil, or of the end of a cigar, being the best. A similar insect frequently attacks the feet, making walking very unpleasant until a cure has been effected. This is best done by the help of an Indian boy, many of whom are excecdingly adept at "spotting" and removing the insects, even before the European is aware of their presence. Wood-ticks and fleas are the curse of the country; compared with these, the snakes and scorpions are no more than a minor inconvenience. 


\section{CHAPTER V}

\section{RAILWAYS, MINING, AND AGRICULTURE}

THE railway lines at present in operation in Nicaragua have a total length of only two hundred miles; but several additional lines and branches are projected, one or two of which will doubtless be commenced when the new foreign loan has been satisfactorily arranged.

The first railway in Nicaragua was commenced in I884, and nearly all the present lines were constructed between that year and 1898 , with the exception of a small gap in the line from Leon to the capital, which was filled during Zelaya's administration.

The lines at present working run from Corinto, the Pacific port, to Leon via Chinandega, whence a small branch-line runs out to El Viejo, and from Leon to Managua, the capital of the state, then on to Granada, with the branch from Masaya to "Los Pueblos"- -a collection of small towns in a rich coffee district, and one of the most beautiful parts of Nicaragua.

These lines, or rather main lines (from Corinto to Granada) with branches, are confined to the Pacific coast; the only means of communication with the interior or with the Atlantic seaboard is by horse or mule back, although stage-coaches maintain a kind of service between a few of the principal towns of the back lands.

The line from Corinto to Granada, like so many railways in the tropics, offers an almost endless panorama of beautiful scenery, although, in the dry season, the 
dust often obscures the vicw, and even finds its way into the carriages. Volcanoes, of which there are quite a number in Nicaragua and all the other states of Central America, appear in the distance, blue and hazy in outline, with flickering plains and green plantations stretching between them.

At many of the stations native women enter the carriages with baskets of choice fruit, home-made cakes, and tobacco. The speed of these trains leaves much to be desired, but the road bed and rolling stock are equal to those of any of the other Central American railroads.

For some hours before entering Managua, the line skirts the shore of the lake, and pretty views of blue, sparkling water, mirroring a million leaves, with encircling hills and tropic foliage, may be enjoyed at the open carriage window, through which a cool breeze blows from the vast expanse of water.

Farther up the line towards Granada, and on the branch to "Los Pueblos" the green of coffee fincas, tree-decked hills and gorges, and a multitude of wild flowers mingle in a panorama of Arcadian beauty.

When the last European loan was obtained by Zelaya, it was generally believed that the funds were to be devoted to the construction of a railway from San Miguelito, on the south-west shore of Lake Nicaragua, to Monkey Point on the Atlantic coast, but this line was never completed, nor really undertaken in earnest, as only a few miles of road bed was made before the work ceased. The new project for linking the Atlantic coast with the Pacific, by a system of continuous land and water communication, is, to run a line from San Ubaldo, on the west side of Lake Nicaragua, to the town of Rama, on the Escondido river, which is navigated by steamers to its mouth at Bluefields. The construction of this much-needed line would open up large tracts of country in Central Nicaragua.

The railway project of premier importance, however, 



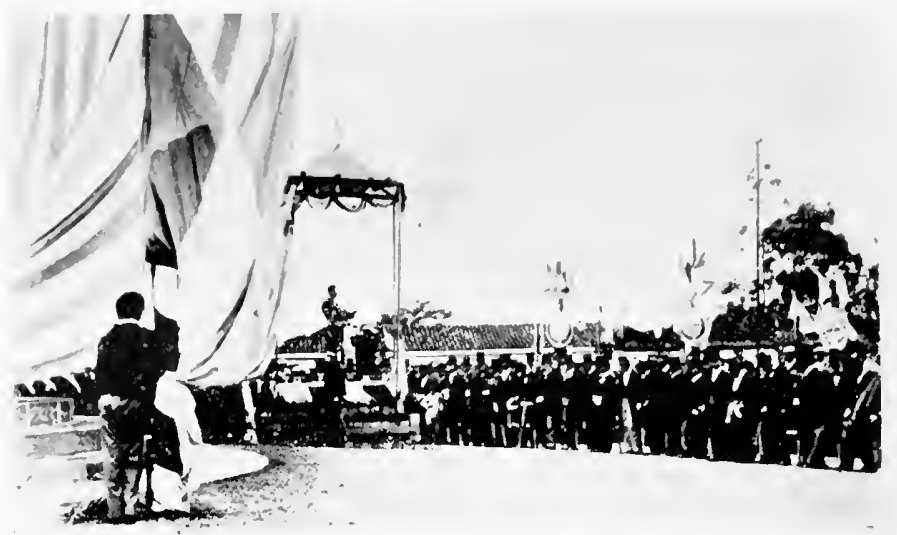

A Public Ceremony in Costa Rica

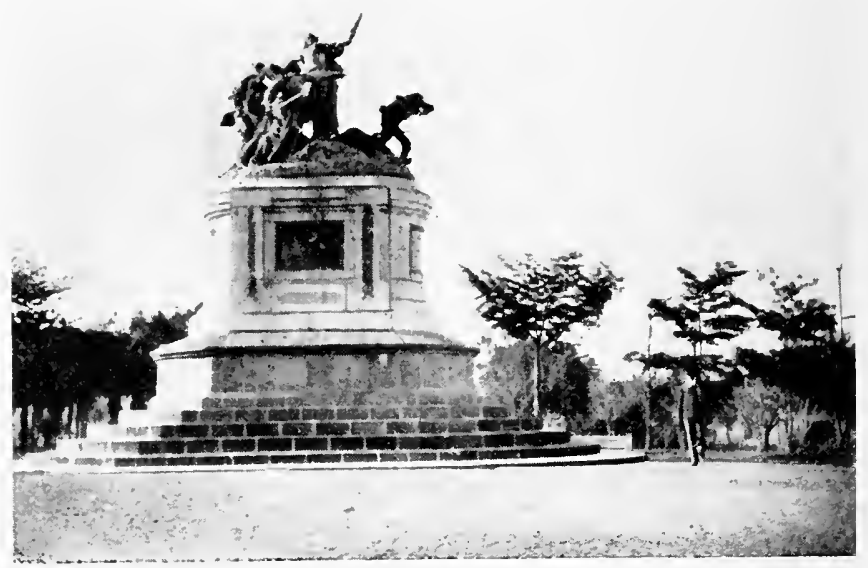

National Monument, San José, Costa Rica

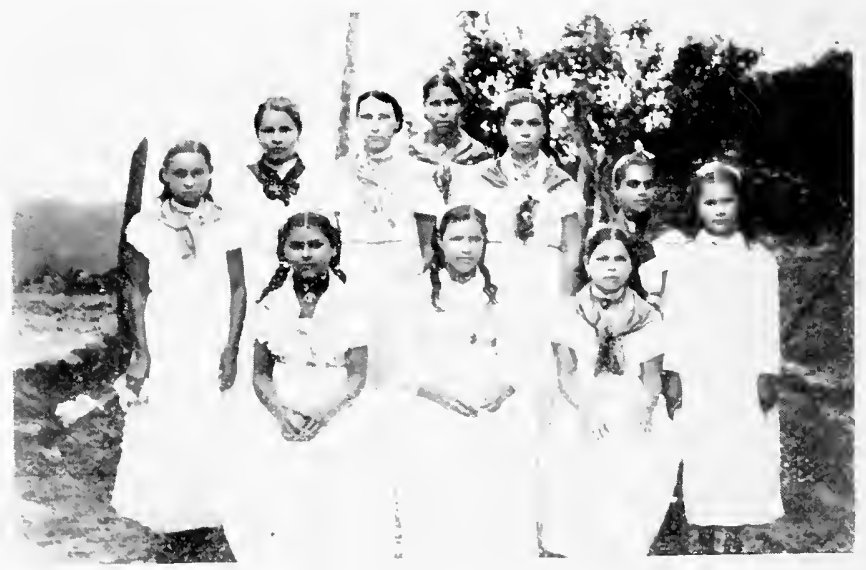




\section{RAILWAYS, MINING, AGRICULTURE 241}

appears to be the construction of a line from Managua to Matagalpa, the most prosperous and most modern city in the country, traversing en route regions in which there is already considerable activity in coffce-planting, mining, and cattle-breeding, with the two most important cities of the country as the termini.

Several other railway lines are projected in Nicaragua, but those just mentioned are the only ones of any importance, or with any immediate chance of materialisation.

Mining is one of the olders industries in Nicaragua. Long before the Spanish Conquest the natives worked the surface-vein and alluvial deposits with very primitive implements, and, if legend be correct, the product was considerable; for history speaks of massive gold and silver ornaments worn by the native belles, and of chains of precious metal by the " medicine men " and chiefs. In the Spanish days, the surface was but scratched, yet we hear of the Jesuit fathers sending a media of gold as a present to the King of Spain.

It was, however, not until the gold rush to California, in $1855-1860$, that mining in Nicaragua received its first impetus. Many miners, returning by way of Central America, " smelt gold," and commenced prospecting. Although rich pockets were seldom found, many considered it worth while to remain and open up several tolerably promising veins. A large number of these small mines died at an early age, but some of them exceeded first expectations, and are being successfully worked to this day.

In this category must be mentioned the Santa Francesca, situated about ten miles from Leon, the Leonesca in Matagalpa, and the Santa Rosa Mine.

About twenty years later gold was discovered in banket reef, on the Atlantic slope, and the placermining, which had been carried on there, in a crude form, for many years, gave place to vein working. 
In the north-east lies one of the richest mineral zones yet discovered in Nicaragua, Cape Gracias à Dios, near the Hondurean frontier, being the nearest point on the Atlantic coast. Here, in what is known as the Pispis region, is the Bonanza Mine, crushing about I 50 tons of quartz a day, the Mars Mine, milling 40 tons a day, and the Lone Star Mine.

These mines, which all belong to an American company, ${ }^{1}$ are equipped with modern machinery, the Huntington mills and cyanide process being operated entirely by electric power, generated by dynamos driven by the falls on the Pispis river.

The north-east, although not covered by any special monopoly, may be termed the American mining zone ; for although placer-mining by foreigners of many nationalities is carried on in many of the Atlantic rivers, notably in the Prinzapolka region, and in the Coco river, American companies own the principal mines. This, however, is not the case in Western Nicaragua, where there are an even larger number of rich mines, nearly all of which are owned by English companies. In the cordillera, on this side of the country, lie the San Lucas, San Cristobal, Ameya, and Quibali mines ; while the Santa Francisca mines, near Leon, have produced more gold than any other property in the country, and the output from the Leonesca mines in Matagalpa, where several hundred men are employed, is now very high.

There are several other valuable mines in Nicaragua, such as the Siempre Viva and El Paraiso, but prospecting has not been carried out on anything like the extensive scale that would otherwise lave been the case, owing to the uncertainty of obtaining concessions in good faith under Zelaya's rule. With the dawn of the new era there is, however, little doubt that the

${ }^{1}$ If they have changed hands recently the author is not aware of the fact. 


\section{RAILWAYS, MINING, AGRICULTURE 243}

mining industry will steadily increase rather than diminish.

Prospecting in Nicaragua is extremely difficult. The bush is thick, and the soil and wash covering the formations are very deep, making location difficult, except along the banks and in the beds of streams and rivers, and at the base of mountains. Transport, mostly accomplished by bullock waggon, is also arduous, on account of the thick forest growth, the absence of roads, and the extremely wet nature of the climate. In the Pispis mining region, the average annual rainfall is over Ioo inches. This, however, does not apply in the same degree to the Pacific slope, where there is a dry season of some duration, but more especially to the Atlantic coast, where the rainfall is abnormally heavy, even for the tropics. Water power is easily obtained in many parts of the country; and the laws governing the granting of mining concessions are exceptionally liberal, the annual tax per claim amounting to only five dollars Nicaraguan money per hectare (I4,I84 square yards), which must, however, be paid promptly, otherwise the claim is sold at auction. No difficulties are placed in the way of a discoverer of a new mineral zone (entitled to three claims), ${ }^{1}$ or of a prospector requiring a claim in a region already opened up, the judge of the district appointing a competent surveyor to measure up the claim and grant the title, the small fee charged being paid by the concessionaire.

There are approximately 500 gold mining claims registered, and silver, copper, lead, iron, and coal are also known to exist, but, up to the present, are not being worked. This is partly accounted for by the lack of transport facilities, and by the absence of any special impetus given, by startling finds, to mining in Nicaragua, although it is certainly to be marvelled at that the undoubted richness of the silver, lead, and copper veins

1 There are several ways of increasing the number of claims. 
have not attracted the capitalist and miner, notwithstanding the drawbacks and difficult prospecting, lack of transport, wet climate, and partial inaccessibility. The average annual exportation of ore from Nicaragua amounts to about $\$ 900,000$.

When all is said and done, the most important industry in every country of the American continent is agriculture, although in Nicaragua it has been much neglected, owing to the lack of labourers during revolutionary times. This, no doubt, partly accounts for the enormous tracts of fertile land still lying unexploited; but, with the complete settlement of the country, and the extension of transport facilities, as the first item in the new programme, it is scarcely likely that these naturally rich lands will long remain unpeopled and uncared for. It is, however, the pioneer who pushes his way where others fear to tread, that, getting land at a very low rate, makes the dollars, when the railway comes, and with it the rush of less far-sighted capitalists.

When considering Nicaragua's present agricultural activity, the cultivation of coffee and fruit must receive first attention. The home of the coffee bush is on the breezy yet sunny slopes of the highlands around Matagalpa, in the "Los Pueblos " district, and, in fact, along the whole Pacific slope. The average annual production of coffee amounts to about I4,000,000 lbs. The decline in this crop during the past few years has been due to lack of labour during the revolution, but now that this period of unrest is passed, and there is a sufficient number of willing labourers at cheap rates, the production of this commodity should considerably increase. It may be of interest to note here that the price of land suitable for the cultivation of coffee ranges from about ten shillings to one pound per acre, while Atlantic lands, available for fruit cultivation, may be purchased at a much cheaper rate. 


\section{RAILWAYS, MINING, AGRICULTURE 245}

The United States take most of the fruit grown in Nicaragua, much of which comes from the Escondido river region; there are, however, a large number of plantations on the Pacific coast.

Although the banana is the chief fruit exported in large quantities, Nicaragua is famous for its limes, oranges, pineapples, mangos, melons, grapes, guavas, and grenadillas, while temperate fruits and vegetables grow well in the highlands.

Cocoa, which is largely exported, is grown in all parts of the country, but does especially well on the warm and moist coast-lands.

Another important product of Nicaragua is sugar, cultivated on the Pacific coast, where the temperature varies but little, and has an average of about $80^{\circ}$. At San Antonio, near Chichigalpa, on the main line from Corinto, is situated the finest and most prosperous sugar estate in the country ; it is owned by an English company having a capital of about $£ \mathrm{I} 20,000$. The area of this fine property is about II,O00 acres, of which some 2000 acres are now planted with cane. The average production amounts, approximately, to about $8,000,000$ lbs a year. The milling plant and other machinery on this estate is of the most modern description; and the company also owns a distillery at Chichigalpa, which produces about 2000 litres of aguadiente (made from sugar) a day.

The total production of sugar in this state, including spirit, has an annual average value of about $£$ I, I00,000.

The vast forests form one of the chief assets of Nicaragua, as it is from these that much of the rubber, fibre, balsam, and dye-woods are obtained. The cultivation of rubber-trees is quite a modern industry, all the rubber produced having been collected, until recently, from the wild trees in the forests bordering the rivers on the Atlantic coast ; and, even now, but little effort is being made to reduce the labour entailed in the 
collection of wild rubber, by clearing the forest growth between these trees, and planting young saplings, as is being done so extensively in parts of South America and in Malaya. Most of the rubber at present $\mathrm{cx}$ ported from Nicaragua comes from the wild trees on the Atlantic slope.

These forests teem with valuable hard woods, such as mahogany, logwood, and cedar, while birds of exquisite plumage, valuable orchids, and numberless other flowers add the necessary touch of brightness to the sombre forest glades.

All over Central America oxen may be seen dragging carts, ploughs, and waggons, these being the animals chiefly used for transport purposes. It is therefore not surprising to find that Nicaragua is the country in which large numbers of these animals are reared, for here they have a double value, being used for transport as well as for food. For centuries this country has been famous for its cattle. The buccaneers, when they desired to replenish their food-supply, made cattle raids up the rivers, and the Mosquito Indians of the coast used to take the warpath in force, to drive off herds from the uplands of the interior.

It has been estimated that there are nearly I0,000,000 head of cattle in Nicaragua, and this can scarcely be an exaggeration, as the average rate of export is 27,000 beasts a year, many of which are sent to Costa Rica for transport purposes.

In the Chontales district are situated some of the largest cattle ranches in Central America, and around Matagalpa, and elsewhere, there are plains which vibrate to the beat of thousands of hoofs. Cattle-breeding on a larger scale forms one of the most profitable industries in this country, and is one of the principal sources of revenue. The annual value of the hides exported alone averages \$I86,ooo United States currency. 


\section{CHAPTER VI}

\section{FINANCE AND COMMERCE}

HaviNG now concluded my description of Nicaragua's rich and beautiful domain, of her people, industries, and commerce ; and having given a brief account of the part she played in the history of Central America, there remains merely to add a few particulars concerning finance and foreign commerce, and briefly to sum up her present position among the five states of Central America. ${ }^{1}$

There are two distinct monetary systems in Nicaragua. On the Mosquito coast, the sol is the unit of value, and money is worth much more than it is in Nicaragua proper, where there is practically no gold nor silver in circulation, the only coins worth mentioning being nickel pieces of the value of one and five centavos. Higher values representing Nicaragua's nominal unit of value - the silver peso, Ioo centavos-take the form of paper bills of from I to Ioo pesos, which are only negotiable in Nicaragua. The rate of exchange is approximately Io-I2 to I-that is, I2 Nicaragua paper pesos equal I United States dollar.

Nineteen years ago, when Zelaya took up the reins of government, Nicaragua was considered by the commercial world to be practically solvent, the rate of exchange being 2 to $I$, instead of I2 to $I$, as it is at the time of writing; but, during the last ten years of his rule, he caused the issue of an enormous amount of paper money, creating such a depression in value as to raise

${ }^{1}$ The army of Nicaragua is but small and ill equipped compared with that of Guatemala: The marine consists of ten small steamboats, many of which are on the lakes. 
the premium on actual coinage to a prohibitive extent, and matters have not yet had time materially to improve since Zelaya's overthrow. At the same time, the country was saddled with an external and internal debt of approximatcly $\$ 25,200,000$ gold.

This is the financial state of Nicaragua at the moment; but the present Government is about to undertake the systematic revision and improvement of the monetary system. Considering the natural richness of the country, and its now bright political prospect, coupled with the slowly rising foreign trade, this should not prove a very difficult matter; nor should the momentary financial position be taken too seriously, for it must be remembered that Nicaragua has only just emerged from a long period of misrule and civil war, and has not yet properly awakened to her great possibilities. The foreign commerce, based on only very indifferent estimates, is approximatcly: exports $\$ 4,000,000$ (dollars gold), and imports $\$ 3,400,000$.

Much of Nicaragua's 49,500 square miles of territory is as yet quite unexploited, and the mineral resources of the country are by no means exhausted, nor even known. The fact that the population has not increased to any appreciable extent during recent years is by no means significant, for large numbers have been killed in the almost ceaseless civil warfare, and others, realising the uselessness of industry and thrift, while the revolutionary period lasted, migrated across the frontier into the surrounding states, while foreign capitalists fought shy of the country, owing, not so much to the danger to life and property, which was always comparatively small, but to the impossibility of obtaining labour, and the difficulties of transport. Now, however, Nicaragua shows every sign of settling down to develop her truly wonderful resources, which, it is no exaggeration to say, should place her in years to come among the foremost countries of Central America. 


\section{PART III}

\section{COSTA RICA}





\section{COSTA RICA}

\section{CHAPTER I}

\section{THE HISTORY AND THE COUNTRY}

That portion of Central America which is contained in the republic of Costa Rica is a region of unusual interest and variety, more on account of its beauty, climate, and fertility, than its historical associations, for during the Spanish dominion it was left almost uncared for, and it now possesses scarcely a single relic or local tradition of those days, so stirring and full of adventure in other portions of the isthmus. The one exception is its discovery by Columbus himself, whose opinion of its charm and value is shown by the name he gave itCosta Rica (rich coast).

When the Spaniards arrived, early in the sixteenth century, the Indians were numerous, and were divided into various tribes, many of which had attained a certain degree of civilisation. They wove by hand coarse fabrics; built strongholds; fashioned crude pottery, considerably more curious than artistic; and carved altars and idols of stone and gold, as well as ornaments, which were used as symbols of personal distinction. They lacked, however, the organisation and cohesion so necessary for the survival of a race, and success in war ; with the result that they offered but a short, though stubborn, resistance to the Spanish invaders.

With the exception of the province of Talamanca, the subjugation of which dates from the beginning of the 
seventeenth century, Costa Rica definitely became a dependency of Spain during the government of Juan Vasquez de Coronado, in 1565 ; henceforth the natives began to decline at a rate more rapid even than was the case in any of the states, and to-day the mixed Spanish population is numerically superior to the native, which is not the case in any of the other states.

Costa Rica, under the Spanish colonial government, formed a portion of the Kingdom of Guatemala, the story of the rise and fall of which has been given in previous chapters. This kingdom included not only the other four states of Central America-viz. Guatemala, Nicaragua, Salvador and Honduras--but also the province of Chiapas, and Soconusco, to-day a part of the Mexican republic. After the Proclamation of Independence in I82I, these states became the federal republic of Central America, dissolving partnership, however, in the year I840. From then until now Costa Rica has been an independent republic, and one in which civil war has been of much less frequent occurrence than in Nicaragua, its northern neighbour, although a revolution occurred some years ago, which was headed by the cowboy, Tomás Guardia, who was quite illiterate. Needless to say, he proved quite incapable of ruling; plunging the country heavily into debt, for a badly planned and only half-finished railway system.

Having already told, in the "Story of the Walker Raid," and elsewhere, the part played by Costa Rica during the various phases of modern history, it is quite unnecessary to dwell further upon these events, the object before us being rather to traverse this territory and examine its economic conditions. Let us begin by a brief study of its geographical position and topography; for thoroughly to understand this country, it is necessary to pay due regard to its physical configuration.

Costa Rica is situated in the south-eastern extremity of Central America. On the north lies Nicaragua, and 


\section{THE HISTORY AND THE COUNTRY 253}

on the south Panama, while its two coasts are washed by the Atlantic and Pacific oceans. It has an area of about 23,000 square miles, and a population of about 400,000 . It is divided into five provinces and two comarcas. ${ }^{1}$ The former are San José, Alajuela, Cartago, Guanacaste, and Heredia ; and the two territories Limon on the Atlantic coast, and Puntarenas on the Pacific coast.

The centre of the country is generally healthy, but the hot coast-lands are undoubtedly malarious. The seasons are fairly well defined: on the Pacific side the rains usually commence about May and continue intermittently until November, while the reverse is, as a rule, the case on the Atlantic side.

A chain of lofty mountains forms the physical backbone of the country, with spurs, like ribs, between which are high plateaus, deep valleys, and extensive coast slopes, giving such a variety of climate and soil as to make nearly all known growths possible.

The central range rises, in certain peaks, to an altitude of nearly I2,000 feet. From the summit of the exvolcano, Irazú, a gorgeous panorama of beautiful scenery is obtained, with a distant glimpse through the azure haze of both oceans-gleaming lines fading into the sky's limpid blue.

From Cartago City the clamber up the sides of this mountain, on the back of a stretching, agile mule, takes but a few hours; but, in this short space of time, the temperature falls from tropic heat to freezing-point.

Climatically the country is divided into three distinct zones, known as the tierras calientes (hot lands), tierras templados (temperate lands), and tierras frias (cold lands). The low coast plains on both oceans, which in Costa Rica are much narrower than in the more expansive states to the north, form the tierras calientes, where the temperature varies from $72^{\circ}$ to $90^{\circ}$ in the

${ }^{1}$ Territories. 
shade. The Pacific side is hotter and drier than the Atlantic, but the forest growth is not so prolific. The coast plains, or, more correctly speaking, slopes, extend from the seashore inland until an altitude of about 3000 feet is reached at the foot of the central range. The temperate zones, on both sides of the divide, include the plateaux, and slopes up to an altitude of about 8000 feet, and from these points to the summit of the mountains lies the almost barren tierra fria.

On the sub-Andian heights of the Sierra, amid the lower oaks or higher myrtles, the variation in temperature between day and night is keenly felt by travellers from the lowlands. It is no unusual event to wake up, after a night's sound sleep in the clear mountain air, just as the sun is gilding the peaks, to find the sleeping bags, and all around, covered with white frost. As the day wears on, however, the heat steadily increases, until one is bathed in perspiration with the efforts of the climb.

The tierras templadas, which comprise the most populated portions of the state, possess a remarkably salubrious climate, are well watered, and extremely fertile. Topographically, these lands are composed of valleys and gently sloping hills, with occasional patches of broken country and a few small plains. The hills are clothed to their summits with the green of coffee bushes and sugar plantations, which are especially numerous in the provinces of San José and Cartago. ${ }^{1}$

Beautiful, indeed, is the landscape in this portion of the country. Piquant little villages, white and gleaming in the clear sunlight, nestle in the midst of tumultuous green foliage. On almost every hill the bungalow-like residence of a coffee planter stands out clear against the serried ranks of bushes, while in the distant valley

${ }^{1}$ To ensure adequate medical attendance the whole country has been divided into twenty-six districts with supervising doctors paid by the State. 


\section{THE HISTORY AND THE COUNTRY 255}

lies San José, the picturesque, neat little capital of this interesting state.

If the vegetation is exuberant in the temperate zones, it is, as a natural corollary, even more prolific on the hot and damp coast-lands. Virgin forests, in which the flora of the tropics shows itself in all its splendours, are here the predominating feature. Palms of kinds innumerable mingle with arborescent ferns, vanillas, cedars, cocobolas, quayacans, and moras. Everywhere there is an underbrush so thick as to be almost impenetrable, while swinging from the branches of the forest giants are the long, flexible strings or stems of a variety of plants known by the generic name of bindweed. The fronds of palms, and ferns of purple and green rise up high over the head of man, while the trunks of the trees are covered with silver lichens and bromeliaceæ, with its thick leaves marbled with curious spots ; orchids of the richest hues, and spatha of deep purple and white, lighten the sombre green and demi-obscurity of the Costa Rican forest. 


\section{CHAPTER II}

\section{THE PEOPLE, THE CITIES, AND RAILWAYS}

LYING between the northern chain of mountains and the southern, which is known as the Montaña Dota, are the broad plateaux of San José and Cartago, having the same name as the two chief towns of the country. These tablelands, which correspond to those in Nicaragua and Guatemala, have an elevation of from 3000 to 4000 feet, and form the live heart of Costa Rica. They are flanked, on the Pacific side, by the Cerro de Aguacati and Cerro de Candelaria, and, on the Atlantic, by the Cerro Mateo. These uplands are the most populated and only properly exploited region in the state.

On the Atlantic slopes, which descend gradually to the low coast plains, the heavy annual rainfall, which averages over Ioo inches, combined with the heat of the sun, produces a remarkably rich forest vegetation, comprising many valuable woods and plants; while large portions of the steeper Pacific slopes are formed of grassy savannas available for the breeding of large herds of cattle. Some parts of the San José and Cartago uplands are suitable for the cultivation of wheat, oats, and barley; but by far the largest portion of these rich volcanic lands are, par excellence, the home of the coffee bush, and the fruit trees of the sub-tropics.

The population of Costa Rica, which has been rapidly on the increase for many years, now numbers about 400,000. Although Spanish blood predominates, there is a very large population of ladinos or mestizos (halfcastes), sprung from the intermarriage of Spaniards with 


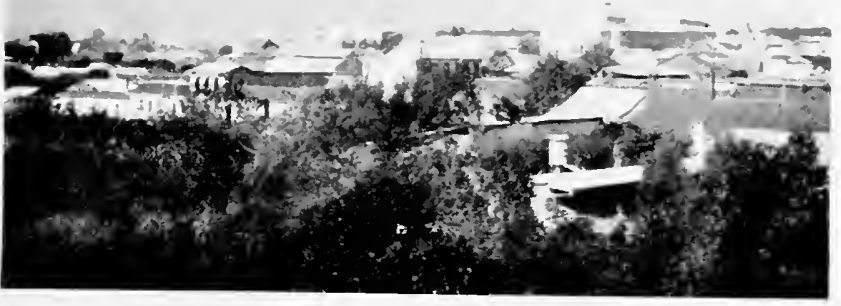

San José, Costa Kica

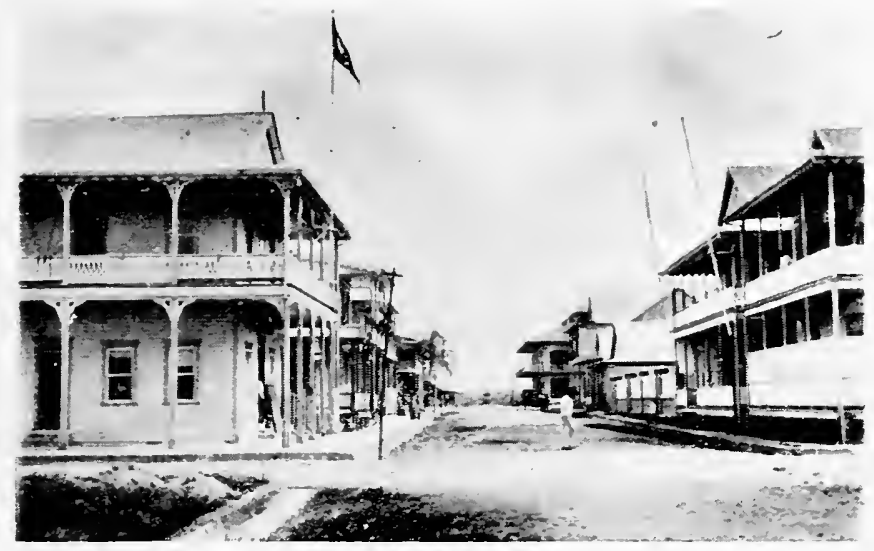

A Street in I'ort Limon, Costa Kica

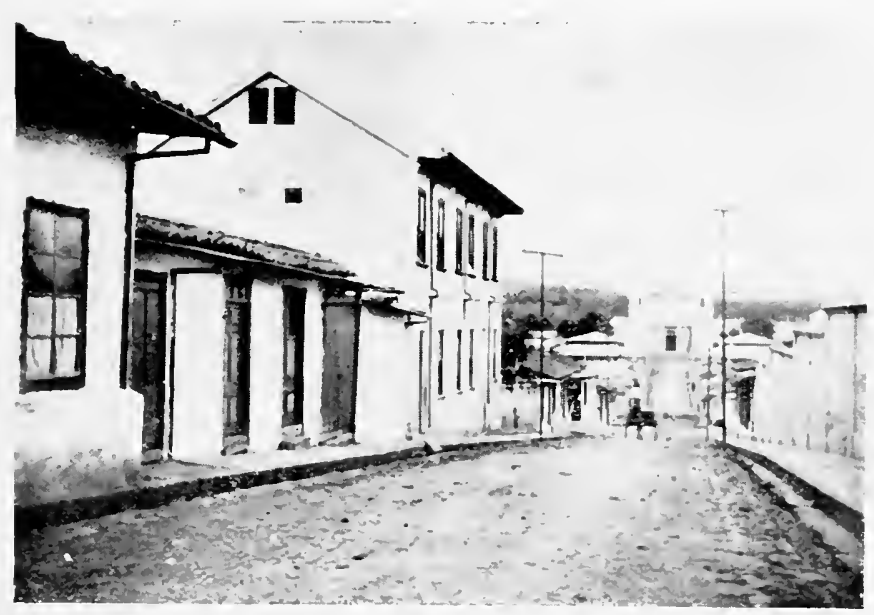

A Street in San José, Costa Rica 



\section{PEOPLE, CITIES, AND RAILWAYS 257}

native Indians. The foreign colony numbers only about 7000, consisting principally of Spaniards, Italians, Germans, North Americans, and Britishers.

The two former nationalities are mostly engaged on the land, with the exception of a few Spanish doctors, engineers and merchants; the Germans are chiefly interested in coffee cultivation, and in the import and export trade ; the Americans in the banana plantations, and mining; while the Britishers are chiefly engaged in finance, shipping and general commerce.

Nearly all the foreigners in Costa Rica reside in the cities of San José and Cartago, or on the plateau, with the exception of a few isolated planters and miners, and a small colony in the two chief ports, Limon and Puntarenas.

In many parts of the country, notably in the Talamanca territory, and along the Nicaraguan frontier, there is but a sparse population of native Indians, known as Prazos, who now number scarcely 5000. In the more remote parts, although quiet and peaceful, they are quite uncivilised, living in stockaded villages, and preserving their old customs and language; but those on the plateau and in the cities have become civilised, and are hard-working, sober, and comparatively honest.

It is a curious fact that Costa Ricans, and Central Americans generally, unlike the people of the South American states, have a somewhat dejected appearance, although there is certainly no cause for this, as they are by no means oppressed or overworked - in fact they are exceptionally prone to "lying under the mañana-tree."

In fairness, it must, however, be stated here that Costa Ricans and Salvadorians may be numbered among the steadiest and most enterprising of the peoples of Central America. ${ }^{1} \quad$ The former are less affected by the

"The term "peoples" is here used in its political sense only, as, correctly speaking, the population of all these states, although of a very mixed character, is cast in one mould. 
waves of tense political feeling which, in the past, have so frequently swept over these countries, carrying civil war and stagnation in their rear-owing partly to a very large class of small, though fairly prosperous, peasant proprietors-while the latter, which, by the way, is the smallest of all these states, were the first to raise the standard of revolt against the dominion of Spain, and to free themselves from the lethargic influence of the temporal power of the Roman Church.

Since the development of Costa Rica as a bananagrowing state, the American planters have brought over a number of negroes from Jamaica. As you journey to San José to-day, you may see these blacks standing beside the line before their huts that tropical fecundity has already embowered in tall grasses and feathery palms. As the train passes the great black men salute it with roars of laughter, as childishly happy as the shouts of the little naked children, who, sticking out their tongues, greet the traveller with a shower of banana skins.

San José, the capital, which lies in a beautiful, green valley, elevated some 3 Soo feet above sealevel, on the central plateau, received the title of city from the Spanish Court in $\mathrm{I} 8 \mathrm{I} 3$, although Cartago, which lies about thirteen miles distant to the eastwards, was the capital during the Spanish dominion.

San José is a quiet and uniform little town, well paved and lighted. Its houses, although only one storey high, as a precaution against earthquakes, are mostly built of red brick, which gives it a more prosperous appearance than many of the other towns of Central America, where the inevitable adobe ${ }^{1}$ and

${ }^{1}$ Adobes were formerly much used in the construction of second-rate houses in Nicaragua. They are big bricks of mud and clay, about two feet in length by eighteen inches in breadth, and one foot in thickness; they are dirty in appearance, and 


\section{PEOPLE, CITIES, AND RAILWAYS 259}

stucco, so white and pleasing from a distance, speaks no less eloquently of the poverty of the people.

When viewed from one of the encircling coffeebush-covered hills, San José creates a by no means pleasing impression, owing to its closely built, unpicturesque regularity. Few trees intersect the mass of low, tiled houses, and there is a notable absence of really large buildings, which-in contrast to the many fine cities of South America-is the case in all these states.

At first sight you may think the capital of Costa Rica something of a fraud, especially if you have been told, as M. de Waleffe was told, that the houses were buried in roses, whereas the truth is exactly the reverse. San José is not more than a glorified village of 25,000 inhabitants, who live in low, uniform, and quite uninteresting houses. The hotel, named grandiloquently the "Palace Hotel," is an inn of an entirely inferior order, badly kept; but its reign is at an end, for already there is rising, or there is about to rise, a magnificent new hotel run on American lines, so that the globe-trotter, even, will soon find himself at home in San José de Costa Rica. Another source of pride to the town is, and will be, the theatre, a fine building on which has been lavished Carrara marble, choice woods, velvets and gildings without end. The one thing it lacks is sufficiency of players; for, indeed, San José is hardly upon the main route of strolling companies!

This disappointing impression on entering the town is, indeed, soon dispelled, and in its place comes a feeling of admiration for the Costa Ricans, who keep this city in such a condition of comparative excellence; for its streets are macadamised, and abundantly are rather readily chosen as homes by snakes and vermin: The word is the Egyptian "! adaub,"' and was carried by the Saracens into Spain, whence it crossed to America. 
supplied with pure water, well policed, and flanked by many quite decent stores and shops. There are two public gardens, the largest of which, the Morazan Park, is well laid out with trees, flowers, and shrubs, forming a fine exhibition of Costa Rican flora. A military band plays frequently, and in the cool sliade of its beautiful trees many pleasant hours may be spent basking in the sunny smiles of the San José scñoritas.

Among the principal, and, at the same time, most interesting buildings, is the cathedral, facing a small park shaded by giant fig-trees. It was built early in the eighteenth century, but restored in I870. Among other buildings are the bishop's palace-for San José is an Episcopal see-the offices of the Government, and the Presidential Palace, the Hospital of San Juan de Dios, and the schools of law, medicine, and physical geography; the national bank; the barracks, and the library, which is exceedingly well arranged, and contains a very large number of volumes, including many standard works in English and French. ${ }^{\mathbf{1}}$

The suburbs of San José are more picturesque than the city itself. Low hills, covered to their summits with coffee bushes, are the predominating feature; a multitude of native huts closely encircle the modern town, while the surrounding hills are dotted with the bungalows of the planters, which, even in the far distance, stand out white against a veritable sea of green.

The staple trade of the capital, also of the chief towns of the province, is in the high-grade coffee for which Costa Rica is famous the world over.

In talking of the capital, we must not pass over one of its principal charms-its women. The Costa Rican maid is an attractive personage. Even though she were not so by nature, which she is, the push of necessity would make her so, for in San José there are

${ }^{1}$ San José now possesses an electric tramway system five and a half miles in length. 
- 


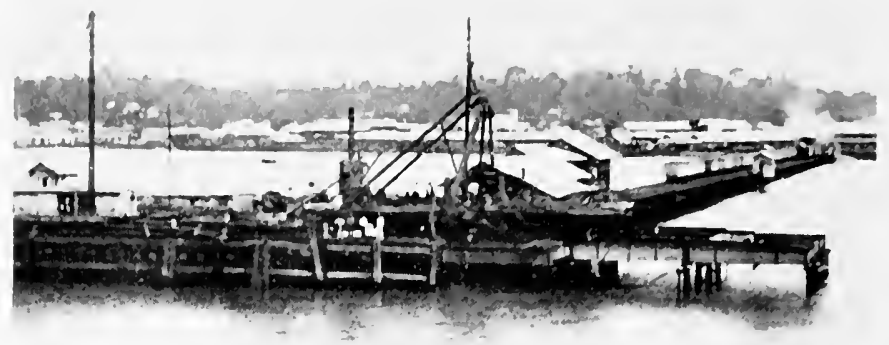

Wharves, Port I imon, Costa Rica

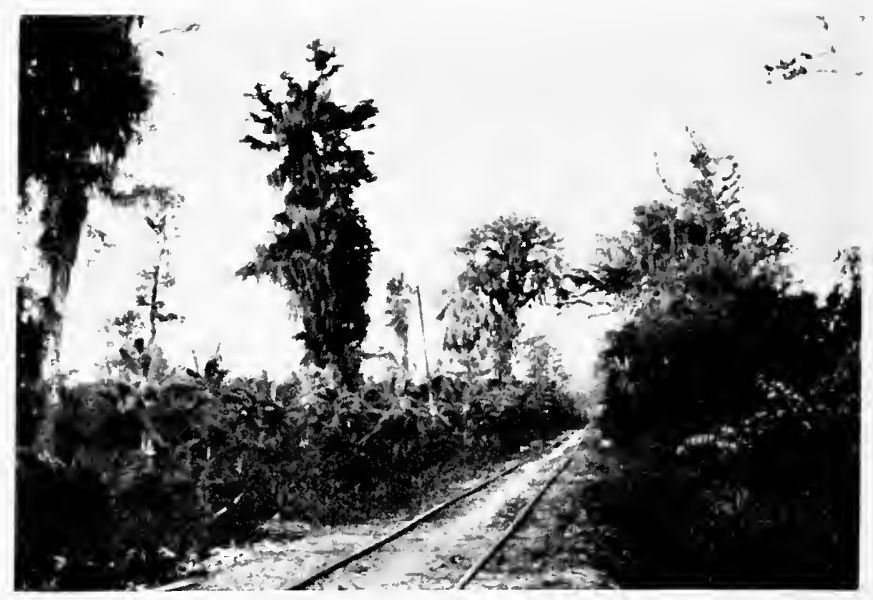

A typical Country Scene on the Costa kican kailway

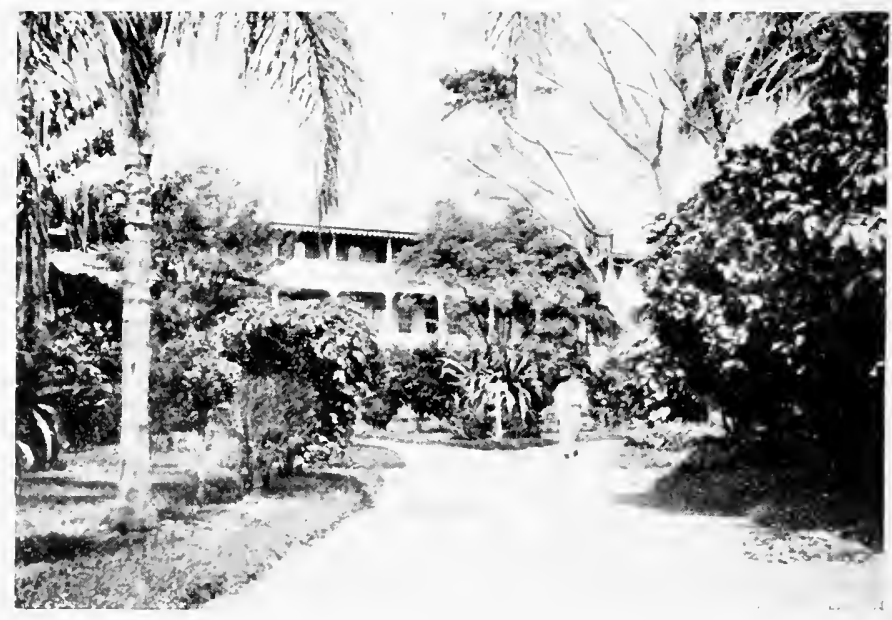




\section{PEOPLE, CITIES, AND RAILWAYS 261}

four maids to every boy. That in part is why, even early on a rainy morning, she conveys the impression that she is about to start for a ball. Before you is a vision of satin slippers and white muslin, beneath a rosy shawl; of thick tresses of black hair set off by a bright scarlet flower; of bright eyes shining out from a face not wholly innocent of the little artifices of a lady's toilet-table.

In such a country as this, all love affairs are apt, according to our notions, to be somewhat volcanic. The Spaniard, in general, is often more gallant as a lover than constant as a husband. Not long ago a French traveller," visiting an old Hidalgo in his finca, congratulated him on the vigour with which he carried his years.

"Yes," he replied, taking his wife by the arm, "I have had thirty-four children by this spouse, and more than forty elsewhere."

By which you will perceive that life in this republic is still somewhat primitive. Talking of republics, if you were asked to place the republic of birds, that Aristophanes, not to mention M. Edmond Rostand, and others have familiarised us with, there could be no hesitation. Your choice must fall on Costa Rica. There are 700 different varieties of feathered creatures, from the humming-bird, no bigger than a butterfly's wing, to the great white eagle, which-if you don't chance to spot him in his native wilds-you can see, in still life, in the museum of the capital.

The Transcontinental Railway, which completely crosses Costa Rica (making the second interoceanic line traversing Central America, exclusive of the

${ }^{1}$ The Garden of Eden is here, says M. de Waleffe, only Adam and Eve are missing. The witty Frenchman hints, that when the Catholic Church has got four-square with modern science, which he thinks it will do soon, in spite of Pius X., then the weapon of the guardian angel will be known no longer as a flaming sword, but as a million of fever-bearing mosquitoes. 
Panama lines) connects San José with the ports of Limon on the Atlantic and Puntarenas on the Pacific. Some thirteen miles eastwards on this line from the capital stands Cartago, the second most important city in this state. It is situated on the plateau, at an elevation of about 4900 feet, and has a population of just under 5000 .

Cartago stands at the base of the volcano Irazh, which, although $I I, 200$ feet high, is comparatively easily ascended, owing to its gentle gradient. From the summit of this giant, on a clear day, nearly the whole of Costa Rica is spread out like a map beneath, and it is one of the long points in Central America where a glimpse of both oceans can be obtained simultaneously.

Irazá is one of the trump cards of the Central American divide, the northernmost spur of the great Andes. On this lofty summit the air is cold and clear, the temperature seldom rising above freezing-point, even at midday. On either hand debris-strewn slopes and austere boulder crests rise and fall, a tempestuous sea of volcanic rock; while stretching away, in front and rear, hills covered with trees and bushes roll on, until merged in virgin forests over which float the filmy mists of tropical jungles. Towns and villages, seen from the distance, lose their size and importance, and flowering plants their colour ; all is a hazy expanse of palest green, closed by the thin, far-off lines of sparkling ocean.

All is, however, not couleur de rose in Costa Rica ; for in the virgin forests lurk malaria and ague, as well as venomous snakes and reptiles; and occasionally the stock farmers in the south-east are compelled to beat a hasty retreat, with their herds, before thousands of migratory vampires, which come up on the wings of the wind in clouds, and in one night will suck the lifeblood from the strongest animal. In the cities, and in 


\section{PEOPLE, CITIES, AND RAILWAYS 263}

all parts of the highlands, earth rumblings are by no means uncommon; and if all becomes suddenly quiet for an undue period, the people become apprehensive, and glance half expectantly at even the quiescent peaks.

Cartago is generally believed to have been founded by Coronado, in 1563 ; and although, in later years, it was sacked on several occasions by buccaneers, it prospered exceedingly, until the transfer of the seat of government to San José after the Proclamation of Independence. From that time, its prosperity rapidly declined, until the coming of the railway line, in I87I, when it slowly began to regain a part of its once famous commerce.

Cartago, however, has suffered, not only from buccaneers and the loss of its political prestige as la capital, but also from volcanic disturbances, as many of its old and interesting churches and other buildings testify to this day. In I723, it was nearly destroyed by the bursting of the flooded crater of Irazk. The torrent rushed down the sides of the mountain, gaining force in the descent, and carrying death and destruction on to the town below. Again, as recently as I84I, the whole town was shattered by a violent earthquake, while minor shocks are of frequent occurrence. Yet all is quiet and peaceful in Cartago's quaint old streets; the climate is healthy, and the death-rate low. One quickly forgets the earth's fires are perhaps smouldering beneath, and there is nothing to remind the nervous of past or possible future calamities, except a few damaged old walls, and the wisely built, single-storey buildings, which would reduce the loss of life to a minimum, even should an earthquake of unusual severity ever occur again.

It is as well to observe here, that, in almost every portion of the Central American highlands, earthquakes and volcanic disturbances are always within the 
range of possibility, and that it is the volcanic soil which makes these uplands so wonderfully fertile.

The only other towns of any importance in Costa Rica arc tlic provincial capitals of Alajucla, population 488o; Heredia, 7200; and Liberia (or Guanacaste), 2900 ; and the two ports of Limon, 3200 ; and Puntarenas, 3600. About these towns it is quite unnecessary to say much here, for they are famous neither for their antiquity, architectural beauty, nor their commerce. An exception to this rule, however, is found in the two ports of Limon and Puntarenas, which form the termini, at the foot of both oceans, of the Transcontinental Railways.

Puntarenas, the Pacific port, on the Gulf of Nicoya, was, before the construction of the railway, the chief custom port of the state, both for importation and exportation, and it still enjoys a very considerable commerce. It has a salubrious climate, and serves as a pleasure resort for the wealthy residents of the interior. Limon, on the Atlantic coast, is no more healthy than any of the other ports on this coast of the American continent, from the mouth of the Plata to that of the Mississippi; but it enjoys a steadily increasing population and commerce. Limon could be made a really first-rate port, by the construction of several small harbour works and breakwaters.

The Transcontinental is the only important railway system in Costa Rica. It was commenced in I87I, and now has a main line from Limon to Puntarenas via Cartago, San José, and Heredia ; and branches are being extended into other portions of the country. The main line runs from the port of Limon along the Atlantic coast, past the small port of Matina, then turns inland and traverses the malarious swamps of the Limon territory, to the foothills at Reventazon, where the lines separate, one branch crossing the mountains north of Irazu to Carillo, and the other line traversing 


\section{PEOPLE, CITIES, AND RAILWAYS 265}

the Ochomogo Pass to Cartago. Both these lines reunite at San José, and the main line continues, branching to Alajuela and the small Pacific port of Tivives, on to Puntarenas. The total length of the railway system is about 460 miles.

This system, which is being extended, is owned partly by the Costa Rica Railway Company, and partly by the Government. ${ }^{1}$ The loss of life entailed in the construction of that section of the line which runs through the feverish territory of Limon was very heavy, apparently even greater than it was in Eastern Guatemala, Panama, or on the Madeira-Marmoré Railway on the Brazilian-Bolivian frontier ; but many years have now elapsed since this line was built, and much experience has been gained of railroad construction in the unhealthy swamps and jungles of the tropics; enabling the loss of life in the carrying-out of these undertakings to be reduced by nearly seventy per cent.

${ }^{1}$ More than one company may own sections of this line. 


\section{CHAPTER III}

\section{AGRICULTURE, MINING, AND COMMERCE}

THE staple agricultural products of Costa Rica may be reduced in number to four, although, naturally, there are many others raised for local consumption only. Of these coffee is the principal ; it undoubtedly forms the chief source of wealth, and the principal article of export.

The cultivation of this commodity in Central America dates from a little over a century ago. The seeds were first introduced from Havana, and planted in Cartago, where to-day may be seen the originals whence have sprung the millions of coffee bushes now flourishing in all parts of Central America. To Costa Rica belongs the honour of having first introduced the cultivation of coffee, now the most valuable production of all these states.

Although coffee was beginning to be cultivated in Costa Rica over a century ago, it was not until I850 that plantations became numerous. The Government of those days foresaw the coming increase in the demand for this product, and wisely took the somewhat unusual step of offering state lands for sale at a reduced price, on the express condition that they should be planted with coffee, in order to produce a new staple industry of immense advantage to the country.

The success of these praiseworthy endeavours is to-day apparent; for the coffee of Costa Rica commands a high price in the markets of Europe and North America, and is famous the world over. 


\section{AGRICULTURE, MINING, COMMERCE 267}

In order to appreciate the extent of coffee cultivation in this state, it is only necessary to remember that nearly $40,000,000$ pounds ${ }^{1}$ of the product are annually exported, and that there are considerably more than 8000 plantations spread over the central plateau. Coffee bushes, however, seldom grow at an altitude higher than 4000 to 5000 feet.

Bananas figure largely in the export, and the cultivation of this fruit comes next in importance to that of coffee. The first shipment to the United States, which consisted of only 360 bunches, was made in I880; since then, the exportation of bananas has gone up by leaps and bounds, until, at the present time, the average annual export amounts to considerably over $2,800,000$ bunches, valued approximately at about $£ 871,000$.

Banana culture, although very frequently carried on, in conjunction with coffee, on the central plateau, is the staple industry of the swampy Atlantic coast plains. In Northern Limon, on the Llanos de St Clara, across which runs the Carrillo branch of the railway, this fruit is very largely grown. Immense plantations border the line for many miles; but, unfortunately, these plains, although eminently suitable for the cultivation of tropical fruit, are decidedly unhealthy. The mortality on the plantations is considerable, except where negroes are employed, as is now mostly the case, owing to the ability of the West Indian and African native to resist the feverish and enervating effects of these damp, hot, and swampy plains.

Sugar-cane is largely grown in many parts of the republic; but the export of the refined commodity is not large, owing to the many uses to which it is put for home consumption. Like coffee, sugar-cane does not grow in Costa Rica at a higher altitude than about 
4000 feet; hence its culture is confined almost to the lower slopes of the cordillera, and to the warm coastlands, where the climate and soil are eminently suitable, and the production is, in consequence, very considerable.

Owing to the many purposes for which sugar-cane is employed, it is difficult to estimate the average production; but, roughly speaking, it amounts to about I 8,000,00o Spanish pounds of fine and ordinary sugar a year. In addition to this, rum, and the brandy of the country-known as aguadiente, a Government monopoly, as is also tobacco-are manufactured from dulce, which is nothing more than the juice of the cane, thickened and defecated. These dirty-looking dulcecakes are often preferred to the refined sugar, by many of the country people. Sugar-cane, cut into short lengths, is also extensively used to feed the cattle and draught oxen.

Among the less-important agricultural products of Costa Rica, cocoa, corn, and beans are the only ones of material value; but, owing to the increase in the cultivation of coffee, cocoa has lost much of the importance it once had.

In 1737 there were more than 273,000 trees in bearing at Matina, in North Limon, which is still the centre of this industry; but, notwithstanding the premiums offered from time to time by the Government, little is now exported, although it is still fairly largely grown on the plains of San Carlos, around Matina, and on the Atlantic and Pacific coasts.

Corn, which is grown in nearly all parts of the republic, flourishes on the central plateau, up to an altitude of about 6000 feet. It is one of the chief foods of the Costa Ricans, who prepare it by first boiling the grains in a solution of lime, then grinding them between stones, and making the paste into thin, round cakes, which they quickly cook on a wood fire. 


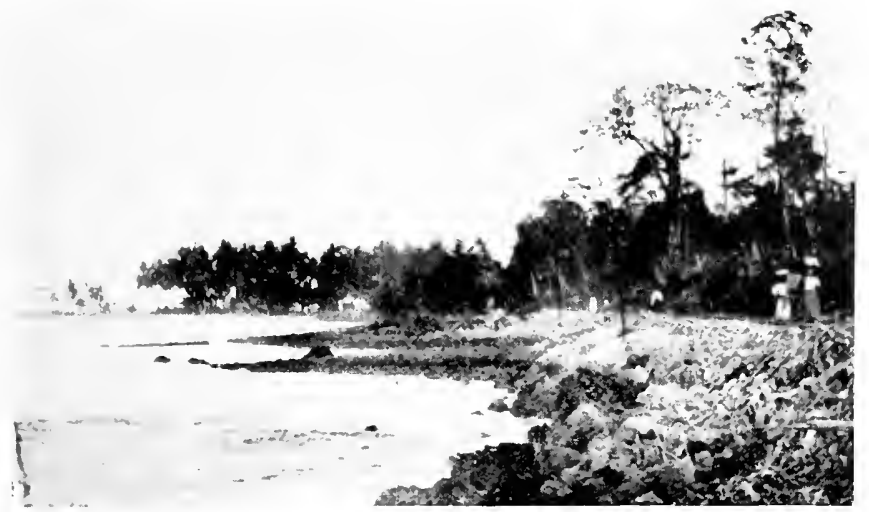

A typical Coast Scene on the Costa Kican kailway

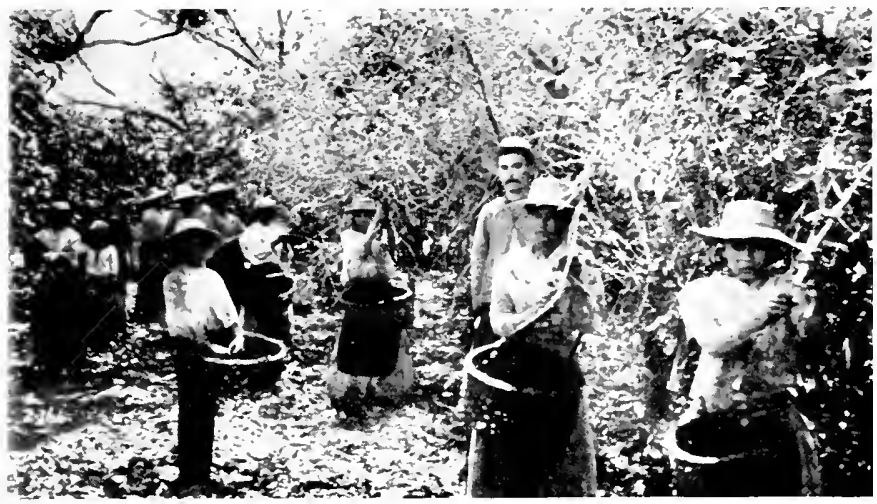

Picking Coffee on a Custa Rican Estate

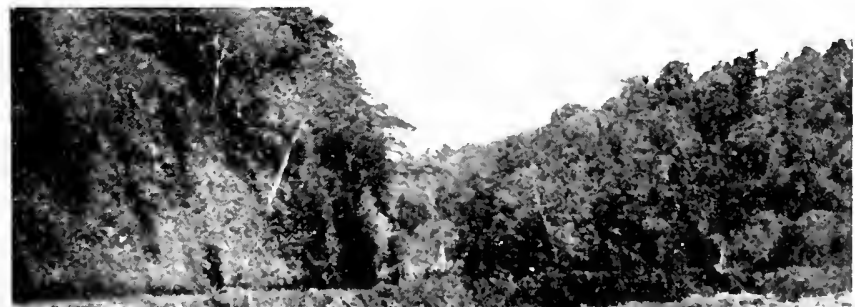

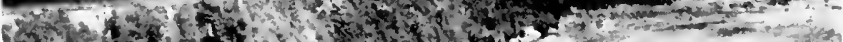

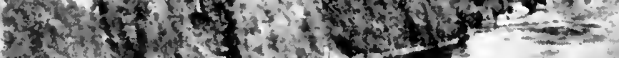

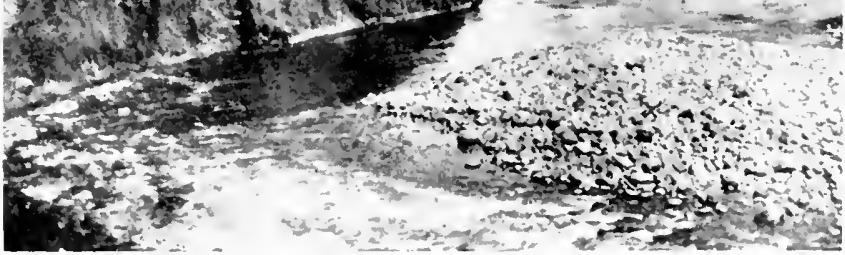

Reventazon River (showing Railway Embankment), Costa Rica 



\section{AGRICULTURE, MINING, COMMERCE 269}

This is the famous tortilla, the bread of the rural population of Central America.

The little black beans, called frigoles, which are grown so extensively in all parts of the country, form, with the tortilla, the main food of the people. Every labourer owns liis patch of frigoles, consequently their unsystematic culture, by all and sundry, makes anything like a reliable estimate of annual production quite impossible.

In the interior, maize, potatoes, and wheat are also grown ; while cotton and indigo are produced, in small quantities, on the Pacific coast. In the forests, vanilla, rubber, medicinal plants, essences, and dyes, as well as textile plants, are collected for industrial purposes.

Costa Rica, notwithstanding its immense area of pasture-lands, so well adapted for the breeding of large herds of cattle, does not raise nearly sufficient beasts for transport purposes, and for home consumption; for although there are about 400,000 head of horned cattle in the country, large numbers are imported monthly, especially from Nicaragua. Of sheep there are only a few thousands, but horse-ranching is slowly increasing, and there are, approximately, about 80,000 of these wiry, sure-footed, lean animals in the state, besides a larger number of mules. The thick mud, during the invierno, temporarily prevents the use of horses as draught animals, yet even in the mountains they are almost as widely used as mules, for " packing" purposes and for the saddle.

The mineral wcalth of Costa Rica is undoubtedly considerable; but, owing to the scarcity of labourers, the absence of adequate capital, insufficient prospecting and mining, with up-to-date machinery, little is being done to develop the deposits, although gold is now being very profitably worked, especially in the Aguacate Mountains.

The total production of gold from the Monte del 
Aguacate mines was estimated, at the close of the nineteenth century, to have exceeded $\$ 7,000,000$ in value.

For many years, silver and copper were also extensively worked, but these mines were abandoned in the eighteenth century, and although numerous other discoveries of rich silver and copper deposits have been made at various times, little more than nothing has been done to exploit them. Iron, zinc, and marble are also known to exist in considerable quantities.

The mining regulations of Costa Rica are, perhaps, better calculated than those of any other Central American state to induce the development of the mineral resources of the country. No charges are levied on mining enterprises, nor are duties imposed on the exportation of the products, while all machinery necessary for the extraction of the ores is allowed to enter the country free of import duty; and public land for the erection of buildings, with the use of water and forest trees, is also granted free by the Government ! Such generous treatment should surely bring about the desired results, for there is undoubtedly much scope for mining enterprise in nearly all the states of Central America.

With regard to finance and commerce, a few statistics, in tabular form, will convey more real information than many pages of descriptive matter.

\section{Finance}

Revenue and Expenditure during past threc years ${ }^{1}$

\begin{tabular}{cccc} 
Year & Revenue & Expenditure & \multicolumn{1}{c}{ Surplus } \\
\hline 1908-9 & $£ 701,173$ & $£ 683,420$ & $£^{17,753}$ \\
1909-10 & $£ 765,986$ & $£ 693,830$ & $£ 72,156$ \\
1910-1 I & $£ 694,833$ & $£ 674,739$ & $£ 20,094$ \\
I912 & $£ 851,670$ & $£ 849,250$ & $£ 2,420$
\end{tabular}

The chicf sources of revenue are: customs, liquor and tobacco monopolies, railways, posts and telegraphs.

${ }^{1}$ Reckoning the "gold colon"" as being worth $22 \frac{1}{3} \mathrm{~d}$. 


\section{AGRICULTURE, MINING, COMMERCE 271}

The principal items of expenditure are, financial obligations, public instruction and development!

\section{INDEBTEDNESS}

Foreign Debt, r9ro

Arrears of Interest on Foreign Debt

Internal Debt

$£ 2,000,000 \quad £$ I, I 50,000 £II 879,44 I (Colones)

The principal expenditure of money obtained has been on railway construction. The total length of line is approximately 400 miles, portions of which are owned by foreign companies.

\section{Foreign Cominere}

Value of Exports and Imports during past three years

\begin{tabular}{|c|c|c|}
\hline Year & Exports & Imports \\
\hline 1908 & $£ I, 582,506$ & $£ 1,182,568$ \\
\hline 1909 & $£ I, 582,500$ & $£_{1}, 182,560$ \\
\hline 1910 & $\ell_{1}, 723,380$ & $£ 1,625,299$ \\
\hline I9I I & $t^{I}, 836,540$ & $£_{1}, 825,830$ \\
\hline
\end{tabular}

The chief articles of export are coffee, bananas, gold and silver, hides, rubber, and cocoa. The principal imports are cotton goods, flour, machinery, and railway materials.

\section{Precedence in Foreign Commerce}

Imports into Costa Rica

Exports from Costa Rica

The United States

The United Kingdom

Germany

France

The Spanish American States
The United States

The United Kingdom

Germany

France

Rcmarks.-The United States are well ahead of Great Britain in both the import and export trade of Costa Rica (bananas). Great Britain imports more 
goods from Costa Rica than she exports to that country, the difference being about $£ 200,000$. Germany, although well belind both of the two former countries, exports to Costa Rica goods of nearly double the value of those she imports from that country. France is considerably belind Germany.

\section{SHIPPING}

The average tonnage entering Costa Rican ports is $I, 200,000$. Of the seven steamship companies regularly visiting the Atlantic port of Limon, two are British, one American, one German, one Spanish, one French, and one Italian. Two American lines call at Puntarenas, the Pacific port. Several British "tramps" and sailing ships call annually at Costa Rican ports.

In conclusion, it may be said, with regard to public services, that the telegraphic system is fairly extensive, though interruption of communication is not infrequent, and only the most populated portions of the country are connected. The postal service, although fairly reliable and regular, is naturally somewhat restricted in area; while the public roads, which make such a brave show in the close vicinity of towns, degenerate into mere beaten tracks in the country districts, and finally become lost in the chaos of mountains, estates, plains, plantations, and jungles of this picturesque little state, which may be most fittingly described as the home of a nation on a mountain plateau. They are safe from invasion, comparatively free from political agitation, and fairly rich in agricultural lands and minerals ; but they are somewhat heavily in debt, for railway construction, and surrounded by vast, unexploited tracts of low-lying, hot, and damp forests and coast plains, less unhealthy on the steeper Pacific slopes than on the more gradual declivity to the Atlantic. Costa Rica, like all the states of Central 


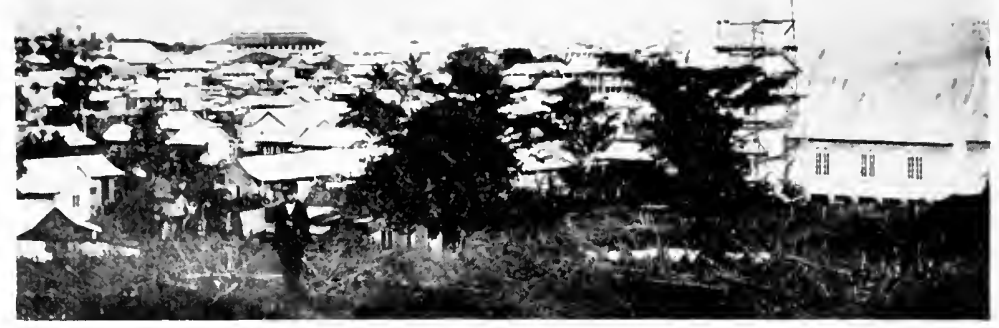

I'ort Limon, Costa Rica

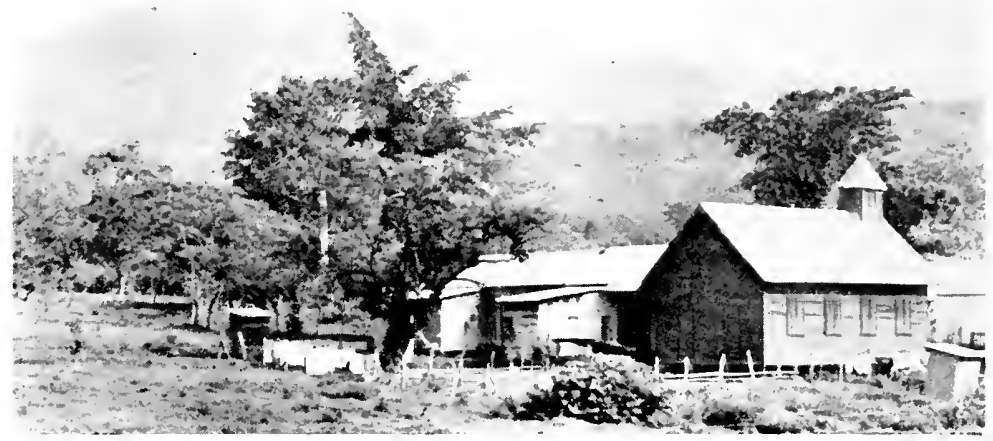

The Turialba Volcano, Costa Rica

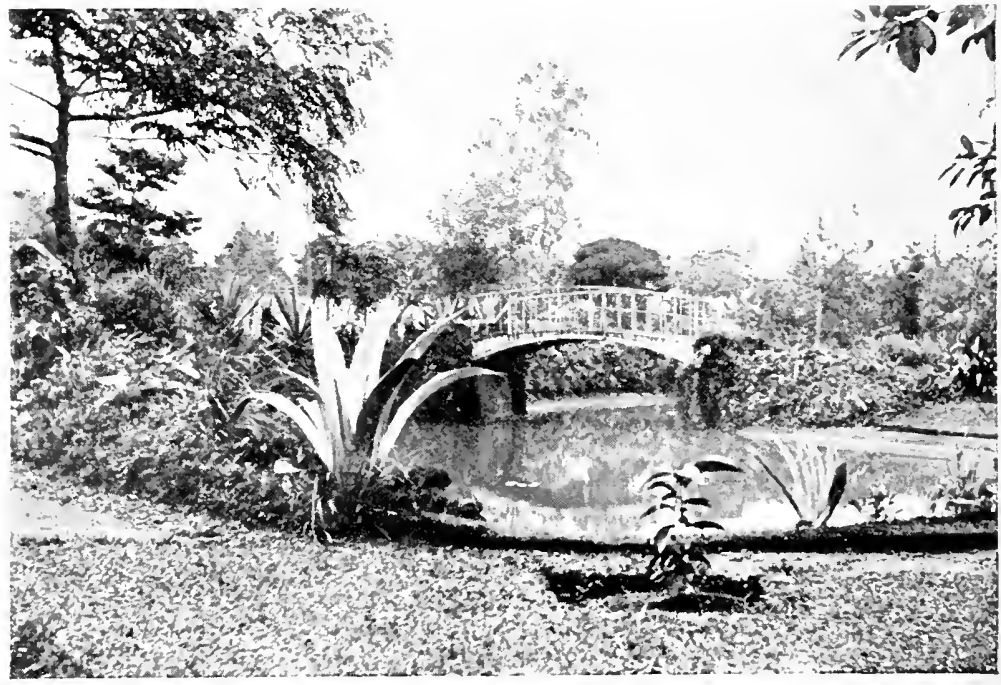




\section{AGRICULTURE, MINING, COMMERCE 273}

America, will benefit greatly from the opening of the Panama Canal.

M. de Waleffe ${ }^{1}$ believes that the United States, not by force of arms merely, but by a gradually acquired commercial ascendancy, will ultimately acquire the whole of Latin America. He freely developed that opinion before Señor Don Gonsalez Viquez, the President of the Republic of Costa Rica. "Take Costa Rica!" replied the President. "Take Central America! But it is impossible! Europe would interpose! Europe would stop it." "How?" retorted the Frenchman.

Her first step towards that end-namely, the control of the Panama Canal, already an accomplished factwill, no doubt, soon be followed by others. Every day her influence in these countries is vastly increasing; already those who formerly would have sent their daughters to complete their education in Paris, or in London, are sending them to New York. All the states, including Mexico, and those of Central America, are doubtless aware of the way in which things are tending ; hence the attempts that are being made to federate Guatemala, Honduras, Nicaragua, Costa Rica, and San Salvador into one republic; but it is a question whether the limited financial resources and energies of these tropical countries will be able to hold out against the pushful determination and the limitless resources of modern finance. The question is one of intense interest to Europe in general, and to England in particular; for, as M. de Waleffe has pointed out, ${ }^{2}$ as surely as Europe discovered America in the sixteenth century, so surely in the twentieth century we may lose it again, not by the old process of having our merchant vessels or our navy sunk, but by the new and not less effective process of American-built tariff walls against all European trade.

1 "Les Paradis de l'Amérique Centrale,"? MI. de Waleffe.

2 Ibid. 



\section{PART IV}

SALVADOR AND HONDURAS 



\section{SALVADOR AND HONDURAS}

\section{CHAPTER I \\ THE MIDDLE STATES IN HISTORY}

SALVADOR and Honduras are the middle states of the isthmus, the former being the smallest, yet most densely populated, of the five republics, having an area of only 7225 square miles, with a population of about $1,200,000$, while the latter is a vast and almost unexploited land, probably comprising the richest mineral zone in Central America.

Through good and evil times, these two states have conscientiously supported each other. From the dawn of their histories, with but few breaks, to the present day, they have acted in unison, both in council chamber, and on field of battle. Victory and defeat they have enjoyed and suffered ; but always maintaining the balance of power in Central America, although more than once they have striven with might and main, first to restore and then to dissolve the federal unity of Central America.

As a land of startling phenomena, Salvador is almost unrivalled in the world; but such miraculous happenings have been more physical than political, although this tiny state, which received its name from the great conquistador, Pedro de Alvarado, took a foremost part in the pronunciamento of independence and the subsequent struggle for partial religious freedom. 


\section{SALVADOR AND HONDURAS}

Recapitulating the events which followed on the Declaration of Independence throughout Central America in $182 \mathrm{I}$, these five states were nominally incorporated, for a few months, in the Mexican Empire, but gained their freedom almost immediately, on the declaration of a Mexican republic in the following year, and formed themselves into the "United States of Central America." They remained, nominally at least, in this state of federation, until the rising in Guatemala, in I837-I839, headed by General Rafael Carrera, who opposed the Federationists under Francisco Morazan of Honduras. Desultory fighting ensued for several years, which resulted, in I842, in the overthrow of Morazan, who was captured and shot, as the reader will already have learned from the chapters on Guatemala.

Then came the period of complete freedom for Salvador, and the combining with Honduras and Nicaragua, in $185^{\circ}$, to restore the federal unity by the force of allied arms. Seldom, indeed, are allied armies relatively as strong as those of a powerful enemy, and they were utterly defeated by the Guatemalans under Carrera.

Next we find Salvador and Honduras opposed to a union by force of arms, fearing, no doubt, a dictatorship by the Guatemalan president, Rufino Barrios, who took up arms in the cause of Federation in 1885 ; but this time the allies were victorious, Juste Rufino Barrios was defeated, and fell a victim on the field of Chalchuapa on 2nd April I885.

Unstable as a barometer in a cyclone, yet with a crude policy, akin to the balance of power directed against Guatemalan dominion, some ten years later we find Salvador, ever the ally of Honduras, combining with Nicaragua to form themselves into the "Greater Republic of Central America," and framing a constitution providing for the admittance in the federation 
of Guatemala and Costa Rica. The latter state, when not holding aloof from these nation-making schemes, has, in the past, shown a marked friendship for its neighbour, Nicaragua---thus making three political groups in Central America--viz. Guatemala standing alone, Salvador and Honduras lying like a barrier across the middle of the isthmus, and Nicaragua with Costa Rica forming the southern extremity.

Little Salvador quickly began to find herself playing but a small part in the federal government, as all states must in a federal entity, and the Greater Republic of Central America fell to pieces, owing to Salvador's dissensions, in I898.

These breezes, warm and cold, were unavoidable concomitants of such a great political change as the federation of Central America, peopled, as it was then, by a totally uneducated and mostly half-breed population. By these gradual, yet oft-times stormy, processes, the now more enlightened populace, with inter-commercial relations far in excess of what they have ever been before, with a community of interests inestimably stronger and more complicated, with natural ties of language and blood more homogeneous through the years of contact, with a generally prevailing spirit of union among the more substantial business men and landowners in all the states, has been slowly educated to the advantages, and disadvantages, of a lasting and powerful union.

Salvador, at the beginning of her career, which really did not commence until the break-up of the first union in $185^{\circ}$, passed through the usual revolutionary period, during which time unprincipled firebrands, with all to win, and naught to lose, or discontented plantation labourers, "native, and to the manner born," donned the multifarious uniforms of gucrrilla chiefs, and were manufactured for political purposes, by those who preferred the less risky, though infinitely more 


\section{SALVADOR AND HONDURAS}

despicable and profitable, rôle of conspirators, in obscurity, into Gilbertian officers of the armies of liberty!

The only discordant note in these romances was the fact that both sides, although with aims diametrically opposed to each other, always fought under the banner of the most delusive goddess in mythology.

In July I906 war broke out between Salvador, Honduras, and Guatemala; but the United States of America intervened, and, through that mediation, a volume of differences were amicably settled within a month. Peace was of short duration; for, in I907, Salvador again lent her aid to Honduras in the shortlived campaign against Nicaragua. The organisation of the allied armies was, however, exceptionally bad, and defeat was the result, but its effect on the steadily rising commerce was by no means disastrous, or even alarming.

Recent years have seen a drastic change in the political conditions of Salvador. Under the Spanish regime it formed a part of the viceroyalty of Guatemala, and in less than a century this tiny country has been first a province in the erstwhile Mexican Empire, then a state in the thrice-formed and thrice-destroyed federation, and is now a separate republic, divided into fourteen administrative departments grouped into three divisions. Its people are more energetic and enterprising than those of several of the other states, although, in this respect, appearances are somewhat deceptive, for it must be taken into consideration that Salvador, with less than a quarter of the area of any of the other Central American states, has nearly double their population; hence its more industrious and exploited appearance is not prima-facie evidence of the superior abilities and morals of its people over their neighbours frequently allowed; but, nevertheless, there is less " mañana," and more true American enter- 


\section{THE MIDDLE STATES IN HISTORY 281}

prise and ambition in Salvador than there is in several of the other states of the isthmus. ${ }^{1}$

Salvador took part in the Washington conference in I907 (sce Guatemalan section) and in the inauguration of the Central American International Bureau in Guatemala City in the following year. ${ }^{2}$

The first president of this bureau, the objects of which I have given in extenso elsewhere, is Señor Echeverria, the delegate of Costa Rica.

No more fitting conclusion can be given to this story of federation attempted, achieved, defeated, and again attempted, than is contained in an extract from the speech of Mr Root, American Secretary of State, when bringing to a close the Washington Conference in I907.

"May the poor labourer, who cultivates the fields in your five Republics, the miner who wears out his laborious life in the working of your mines, the mothers who to-day are nursing the children who will be in the future the men of the Central American nations; the millions of beings whose prosperity and happiness you have endeavoured to ensure here; the future generations of your beloved lands-may all these look back with pride upon this day and bless you for the selfsacrificing devotion and prudence with which you have worked to serve their interests, ensuring for them peace and prosperity."

1 The "Most Favoured Nation Treaty" with Great Britain was signed in 1860 .

2 The assassination of President Aranjo--deeply regretted in Europe and America-is the most recent event in Salvadorian history. 


\section{CHAPTER II}

\section{SALVADOR TO-DAY}

SALVADOR is, perhaps, the most curious country on the American continent. Its size is infinitesimal, yet its population is relatively large; its topography and climate present two marked extremes; for the very narrow strip of low-lying, alluvial coast-land is hot and malarious, while the largest portion of the interior of the country, which is long and narrow, is formed by a healthy mountainous plateau about 2000 feet above sea-level, on which stand numerous groups of volcanic cones.

Volcanoes rise precipitously from the ground, the earth trembles frequently, lakes rise and fall, and rivers which have flowed peaceably for many years suddenly become rushing torrents, bursting their banks and scooping a channel for themselves in the loose volcanic soil and rock. Yet, withal, the death-rate is exceedingly low, the births exceeding the deaths by an ever-increasing number. Seven times has San Salvador, the capital, been all but destroyed, yet eacls time it has been rebuilt, and to-day, housing over 60,000 people, stands as a monument to the fearless perseverance of the Salvadorians.

One of the chief products of the country is " Peruvian Balsam," which has never been grown in Peru, but owes its name to the simple fact that many years ago it was first shipped from this coast to the Peruviar port $_{\text {of }}$ Callao, and from there transhipped to Europe.

These few curious facts could be multiplied almost 
indefinitely, but sufficient has been said, for the present, to show the remarkable character of the country itself. Even the population, which is stated to be about I,200,000, formed principally of ladinos (whites and half-breeds), sixty per cent., and Indians forty per cent., presents a curious contrast with the people of the neighbouring state of Honduras. The Salvadorian labourer will labour, if the task is reasonable, and his treatment considerate, while the Honduras prototype (of the interior) will only work when compelled, and even then with a very bad grace.

Perhaps the only conditions more regular in Salvador than in the other Central American states are the climate and seasons. The very narrow coast-for Salvador has no Atlantic seaboard, being washed only by the Pacific Ocean-is low-lying and feverish, though the rainfall is not excessive; but on the plateau and among the mountains of the interior-if the highlands 'way back from the actual sea-coast can so be called in this narrow maritime state-the climate is comparatively cool and healthy. This may to a certain extent account for the more energetic temperament of the people, for in many of the other states there are vast tracts of low-lying, malarious and enervating jungles. There are two decided seasons in Salvador; the wet period begins in May, and lasts till October ; during the last two months the rainfall is almost continuous, although, curiously, by no means torrential. This season is called winter, although the atmosphere is warm, and with the exception of the months of September and October, many hours of sunshine are enjoyed. The dry season sets in about November, and lasts until the beginning of May. During these months rain seldom falls, and hot, sunny days, with a sky of limpid blue, are followed in regular succession by nights of Arabian splendour with a starry vault of deepest indigo above, and silvery moonlit plains and mountains below, with the fiery glow of a 


\section{SALVADOR AND HONDURAS}

crater casting its lurid gleams into the dark sky, and showing far out on the broad Pacific, lighting on their way up the Salvadorian coast " ships that pass in the night."

Agriculture is far and away the most important industry of Salvador, although mining is carried on in many parts of the country. Coffee is the chief product, as it is now in all the states of Central America. The export of this article alone accounts for about $£ 800,000$ of the $£ I, 300,000$ which forms the average total value of the annual exports of the state. Sugar, which is fairly largely grown on the hot, damp coast ; indigo, the cultivation of which is decreasing in favour of cotton ; and the famous balsam, collected near Cape Remedios, known as the "Balsam Coast," are the only other products of any importance.

The Salvadorian cordillera is, undoubtedly, rich in various minerals, such as copper, iron, and lead ; but, at present, gold and silver are the only ores being worked. In the extreme west of the country iron, in considerable quantities, has been discovered, and coal is known to exist in the valley of the Rio Lempa, which is the largest river in the country and has several important tributaries. Rising on the Guatemalan frontier, it crosses a corner of Honduras, and, after traversing a fertile valley running through the cordillera, empties itself into the Pacific. The Rio Lempa is navigable for shallow draught steamers for a considerable portion of its total length.

The department of Morazan is the chief gold-mining region of the state. Here there are many British and American, as well as national, companies working the deposits. The average annual output of gold and silver from all the mines in Salvador, however, does not exceed in value a quarter of a million sterling. ${ }^{1}$

There is in Salvador, as in so many of these states,

${ }^{1}$ During recent years the Government of Salvador has introduced a standard gold and silver coinage: 
ample scope for the prospector with the capitalist behind him, for the impecunious miner, used to the shallow alluvial workings in parts of Australia and at Klondyke, would stand but a poor chance in Central America.

The oversea commerce of Salvador is fairly large, considering the size of the country. It consists chiefly of the importation of cotton and woollen goods and machinery, and the exportation of coffee, gold, and balsam. The total value of the imports averages about $£ 805,000$ a year, and the exports approximately $£ \mathrm{I}, 300,000$.

As in all these states, the revenue is principally derived from the high import and export duties, although excise, licences, and postage, as well as other internal charges, account for a considerable portion. The revenue and expenditure during the last five years is shown in the following table, the value of the Salvadorian pesos being reckoned at the rate of twelve to $f^{\mathrm{I}}$ :-

Revenue and Expenditure of the Republic of Salvador, I907-I9II

\begin{tabular}{|c|c|c|c|}
\hline Year & Revenue & Expenditure & Surplus \\
\hline 1907 & $£^{691,453}$ & $E^{840,817}$ & $\ldots$ \\
\hline 1908 & $E_{1}, 010,82 \mathrm{I}$ & $£ 966,704$ & $£ 44,1 \perp 7$ \\
\hline 1909 & $£ 955,045$ & $£ 900,337$ & $£ 54,708$ \\
\hline 1910 & $£ I, 049,087$ & $£ 997,994$ & $£ 51,093$ \\
\hline I9I I & $t^{8} \mathrm{I} 6,983$ & $t^{821,106}$ & $\ldots$ \\
\hline I9I 2 & $\$$ I $3,129,750$ & $\$ \mathrm{I}_{3,2} 86,750$ & $\ldots$ \\
\hline
\end{tabular}

The foreign debt outstanding amounted, in IgII, to $f^{I}, 46 \mathrm{I}, 552$. The interest on the financial obligations having been duly met, and the foreign and internal trade being steadily on the increase, Salvador may be considered financially sound, and commerically prosperous, although here again the law of contrary is apparent, for there are more comparatively poor people in this country than there are in some 


\section{¿86 SALVADOR AND HONDURAS}

of the larger states. This is possibly accounted for by the wider area of agricultural land possessed by the larger states, with a relatively smaller population. If she is wise, Salvador will make herself the manufacturing nation of Central America, and, incidentally, one of the strongest military powers. Good material for both these essentials is at hand; and initiative and guidance are all that are needed. 


\section{CHAPTER III}

\section{THROUGH SALVADOR TO HONDURAS}

THE three chief ports of Salvador-which is the only one of these states without an Atlantic seaboardare: Acajutla, La Libertad, and La Union. Although situated on the narrow, stifling coast plain, these towns lie almost in the shadow of the cool, breezy uplands of the volcanic coast cordillera, which, in places, is rent asunder by broad and fertile river valleys, wherein are situate many of the finest plantations of the country.

The coast plain, hot, dusty, and by no means salubrious, is naturally the least populated and most uninteresting portion of the state, although choice of locality lies between these lowlands, the volcanic plateau, and the high mountain slopes in the far interior on the friontiers of Guatemala and Honduras, with the possible alternative of a few very fertile valleys, filled with rich plantations and watered by broad, shallow rivers. Yet the tropical Pacific coast, on which the cultivation of cotton is steadily increasing, owing to the wise inducements offered by the Government, cannot be passed over without reference, for it includes the ports-the outlets for the foreign commerce of the country-which, although at present little more than seaside villages with safe anchorages, are nevertheless commercially of ever-increasing moment.

Acajutla, connected by a railway line with Santa Ana and La Ceiba, and also with San Salvador, the capital, has been moved during recent years to a more sheltered spot, distant from the old port about one and 


\section{SALVADOR AND HONDURAS}

a half miles, where an iron pier, together with covered warehouses, a custom-house, and a number of unpretentious dwellings, have been erected. Its situation in the west of the state makes it a convenient port for the oversea commerce of the inland town of Sonsonate, and the fertile highlands around Santa Ana. This latter city, owing to the many disastrous earthquakes suffered by the capital, has become the busiest town in Salvador.

La Libertad, which will shortly be connected by a light railway with Nueva San Salvador, a small town on the main line close to the capital, is situated in the centre of the coast-line, in a position favourable for handling the foreign commerce of the capital and surrounding district, although as a landing-place it is by no means satisfactory; while La Union, the eastern port, and only other one in Salvador worthy of mention, lies in the well-sheltered Gulf of Fonseca. Although connected with it only by good roads, La Union derives much of its commerce from the neighbouring town of San Miguel, which has a population of nearly 25,000 .

The chief inland towns are: San Salvador, the capital, population about 59,600; Santa Ana, 48,200 ; San Miguel, 24,768; Nueva San Salvador, I8,700 ; San Vicente, I7,832, and Sonsonate, I7,000.

There are many other small and typical Central American townships scattered over the whole country, such as Ahuachapam, near the Guatemalan frontier, which is generally believed to be situated on the site of the old city of Paza; the neighbouring towns of Atizuisaya and Chalchuapa, near Santa Ana, which, although now surrounded by peaceful sugar and coffee plantations, were once the scene of battle in the wars between Salvador and Guatemala. At Chalchuapa, in I885, Rufino Barrios, the Guatemalan Federationist, was defeated and killed; while the small towns in the 


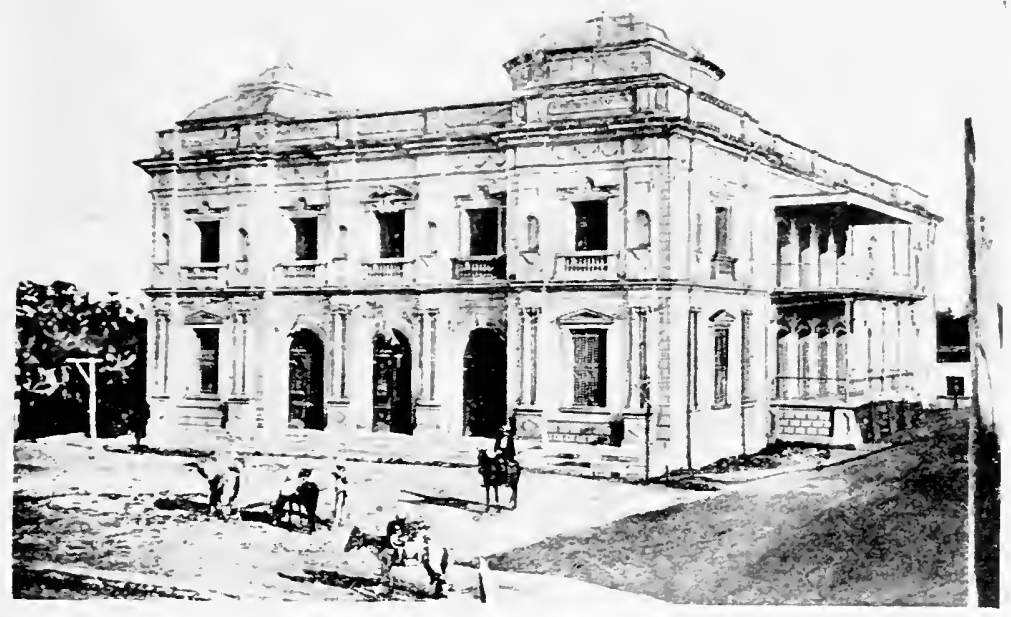

The Theatre, San VIiguel, Salvador

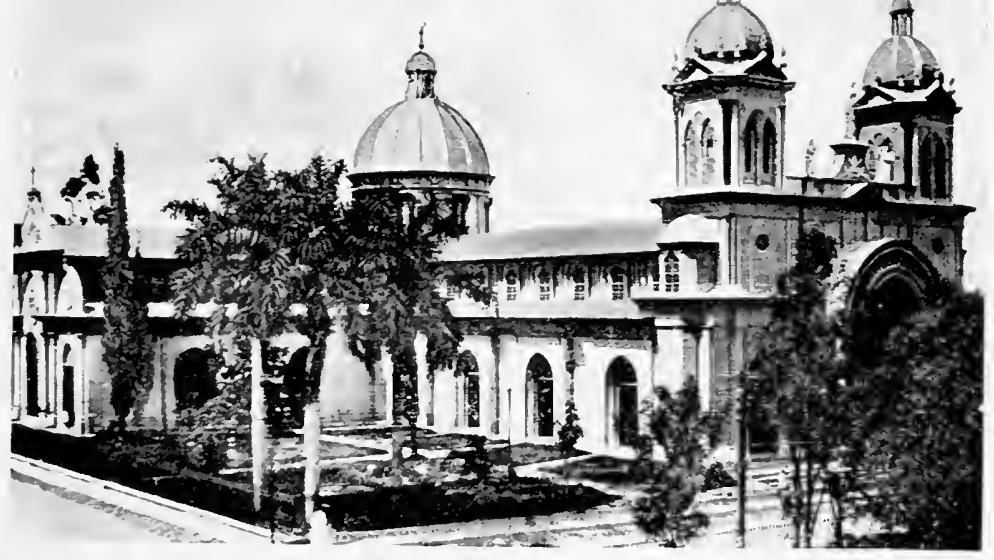

The Cathedral, San Salvador 



\section{THROUGH SALVADOR TO HONDURAS 289}

eastern portion of the state among the mountains on the Honduras frontier, although, perhaps, historically of less interest, are centres of considerable agricultural and mining activity.

In all the other Central American states there is a " dead land," where the natural resources are neglected, and the population is sparse ; but in Salvador, agricultural and industrial activity is manifest in all save the few arid patches of the country.

Sonsonate, revelling in the poetical title, "Four Hundred Springs," was at one time the most important town in West Salvador, but has since been eclipsed by Santa Ana, which, although by no means architecturally a beautiful city, or one of more than passing interest, is situated in a good agricultural district, and is in close proximity to the rich mineral region of Metapan, north of Lake Guija.

Sonsonate lies in a fertile and well-watered plain dominated by the volcano Izalco, known as the "Faro del Salvador" (Lighthouse of Salvador). This burning mountain, like the Jorullo of Mexico, is comparatively of modern birth, having made its appearance suddenly in I770. Previous to that, the district around Sonsonate was occupied by ausoles, similar to those near Ahuachapam, which have now been extinct for many years. ${ }^{1}$ On 23rd February I700 the earth suddenly opened, and streams of fiery lava and showers of hot ash were thrown out. The explosions were as regular as minute guns at sea, and in a very few weeks Izalco rose to a height of nearly 4000 feet ! Still the violent explosions continued, and for years this volcano continued to throw out volumes of flame, smoke, and ashes, which, at night, lit up with a lurid glow the plains of Sonsonate, and, showing far out to sea, earned for it the title of "Lighthouse of Salvador."

${ }^{1}$ Hence the title given to Sonsonate-viz. "! Four Hundred Springs." 


\section{SALVADOR AND HONDURAS}

Curious as these phenomena certainly were, they were eclipsed by the more recent happenings near the capital. Seven times has this city been all but shaken to the ground byviolent earthquakes, and, although it has been rebuilt after each disaster, the buildings are nearly all light, one-storey structures, pointing unmistakably to the inherent caution of the people, and to the precarious nature of house property in this little city, whose population, the year round, works and plays in the shadow of a dozen volcanic cones.

Some six miles eastward of the capital lies Lake Llopango, which was the scene of one of the most remarkable volcanic disturbances recorded in history. Llopango stands on the plateau some 1600 feet above sea-level, and has an area of about 25 square miles. It is surrounded by lofty mountains sloping precipitously down to its rocky shores, the only level ground being two small clefts in the rock, on which stand the villages of Apulo and Asino.

The first signs of this truly wonderful disturbance occurred in December I879, when the surface of the lake rose suddenly about five feet, causing the Rio Jiboa, which flows out at the south-east corner, to transform itself from a slowly moving, shallow stream into a foaming rapid some forty feet deep. This sudden egress of water, estimated at thousands of millions of cubic feet, caused a corresponding drop in the level of the lake, which subsided about thirty feet in less than the same number of days. This phenomenon was accompanicd by violent convulsions of the earth; and subterrancan explosions, which shook the capital and the whole centre of the country. Contemporaneously with the fall in the lake's surface, poisonous vapours were emitted from its centres; a volcanic cone, surrounded by numerous islets, rose about the seething cauldron, then came the fire, the lava, and the ashes, a conflagration that lit the mountains 


\section{THROUGH SALVADOR TO HONDURAS 291}

for miles around, and darkened the sky all over Salvador.

When all was over, an island of solid lava some I6o feet high remained in the centre of the lake; the waters resumed their normal level, but the shocks had destroyed nearly all the buildings in the city of San Salvador, six miles distant.

Although in the neighbourhood of the capital there are quite a number of craters, no eruption other than the one just described-in which the shocks and not the actual eruption were responsible for all damage doneis recorded in history. Earthquakes have been of more or less frequent occurrence, but, happily for the people of San Salvador, the volcanic cones surrounding them have been quiescent for centuries.

Groups of volcanoes are scattered over many parts of this small country, but most of them have shown no signs of activity for very many years ; there are, however, a few which darken the skies by day and light them with a dull red glare by night. Few scenes of more awe-inspiring grandeur can anywhere be witnessed than Izalco's glow or Miguel's smoke.

In the clear sunlight, a thin column of blue-grey smoke, growing broader and less defined as it curls upward into the cerulean sky, is all that shows of the earth's fires beneath. Afar and near, green-clad slopes, bare rocky summits, and tree-filled valleys, with broad plains covered with the inevitable coffee bush and sugar-cane, dappled here and there with a village, spread out in a panorama of warm, slumberous beauty. Deep in yonder valley lies the silvery streak of a river sparkling for a brief space, then lost amidst the maze of hazy green vegetation; but no filmy wreaths of aguish mists float between the trees on the plateau near by, as in the tropical forests of Central America's Atlantic coast. The atmospher is cool, and the energy, sapped so quickly from the human frame on the damp, malarious 


\section{SALVADOR AND HONDURAS}

lowlands in the Equatoria, returns on the wings of the light Pacific zephyrs tempered by the altitude of the Salvadorian heights.

When night falls-and it does so rapidly in Central America-the dark mountains are clear-cut against the luminous blueness of the sky. The volcanic beacons grow brighter as the darkness increases, until their fires show lurid and awe-inspiring above the black outlines of the craters. Lights twinkle in the valleys beneath, and 'way back on the plain the lights of a town intensify the darkness around. The song of a plantation labourer floats up from the valley with the tinkling of a guitar; then between the lighting of a cigar and the fall of the first ash, the moon rises, large, round, and mellow, above the lonely mountains of the Hondurean frontier. Higher as it mounts in the heavens, brighter it grows and more silvery, casting a wealth of warm, mystic light on all around. Mountains and trees are silhouetted against the brightening sky. A silence which can be felt settles over the earth, and only the howl of a beast and the night call of some frightened bird break the stillness of a Central American night.

If Salvador suffers more from earthquakes than some of the other states, and its cities lack the architectural grandeur of great capitals, she amply atones-at least, such is the opinion of the author-in the richness of her soil, the beauty of her scenery, and the courteous hospitality of her people. 



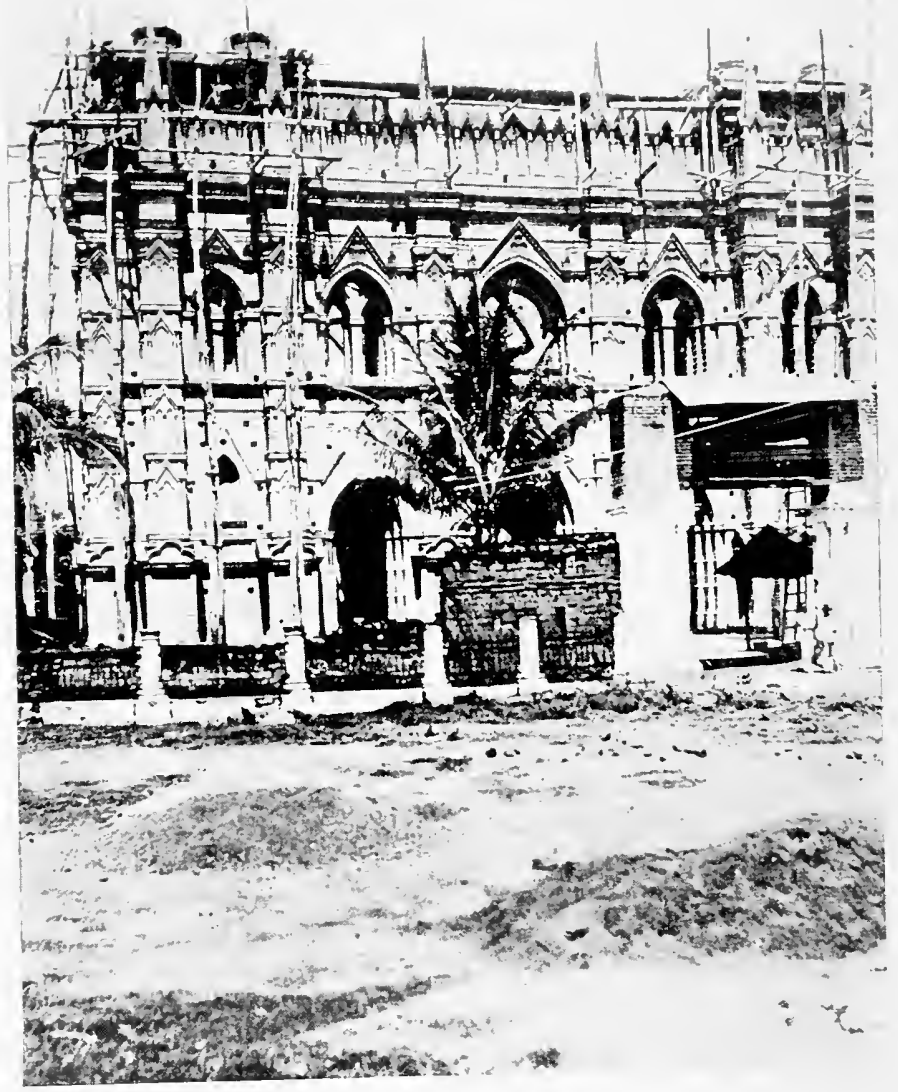

The I'arish Church, Santa Ana, Salvador 


\section{CHAPTER IV}

\section{HONDURAS}

Across the lone mountains forming the north-eastern frontier of Salvador lies Honduras, the least exploited of all the Central American states. Without even such pioneer undertakings as a complete, though indifferent, railway system - for there are barely sixty miles of track in operation-this country, comprising 46,250 square miles of undoubtedly rich territory, varying in topography, climate and resources from the tierras templadas of the interior to the fever-lands along the Atlantic coast -a series of gently sloping, broad plateaus, rugged and wild, broken by mountains and sluggish rivers, and covered in places with a density of forest growth unparalleled elsewhere in the isthmus-is a terra incognita even to the people who inhabit it !

Honduras is another of those Central American lands in which Nature is silently awaiting the coming of the rancher, the farmer, the fruit-grower, to whom she will return full measure for all their labour. No land on earth has more and greater natural advantages, no land on earth has utilised them so poorly.

Ask a prosperous merchant, in the cleanly painted stucco town of Tegucigalpa, what the country is like around the Caratasca Lagoon, or whether the way across country to San Jago is difficult, and, unless he has had special occasion to visit these wide-apart districts, he will in all probability be quite unable to give you any reliable information; and the same may be said, in an even greater degree, of the native who cultivates his 


\section{SALVADOR AND HONDURAS}

little patch of beans and maize, or wanders slowly through a banana plantation with an air of indolence and cnnui excusable only by reason of the moist, cnervating heat.

Yet Honduras has many beautiful and fertile regions, salubrious and full of promise ; many unquestionably rich mineral zones, perhaps of a wealth yet unknown in Central America; and offers many openings for the larger pioneer undertakings which have been only left for the present generation by the almost unexplored condition of this country, the undoubtedly lethargic disposition of the people-whose misplaced spurts of energy have, from time to time, been exhausted in unprofitable revolutions-by the sparseness of the population, which scarcely exceeds six persons to the square mile; for, as in all these states, the independence bought so cheaply at first cost has involved in the end a century of bankruptcy and stagnation.

When entering Honduras from the Pacific, there is no need to traverse Salvadorian territory, for Honduras possesses a small coast-line on this side of the continent. It half encircles the Fonseca Gulf ; and Amapala, the chosen headquarters of one of the ill-starred federation movements, is the chief port.

About Amapala, or, in fact, concerning this coast in general, little can be said of interest, for it is merely a wedge of broken country, with a very hot climate, thrust in between Salvador and Nicaragua; but it serves an important purpose, for it gives to Honduras an outlet on the American Pacific coast, up and down which floats much of the commerce of these states. Amapala is a quaint little town of some 3000 inhabitants, which makes up in surrounding scenery what it lacks in structural beauty. Its position on the shores of the well-sheltered Fonseca Gulf, which provides a safe anchorage for vessels of considerable size, and the merchandise which enters the country through this 
gateway were the causes of its existence, and its hope for a prosperous future.

Regular calls are made at Amapala by vessels of the Pacific Mail Steamship Company, and the Kosmos line, but the ocean cable, dircctly connecting so many of the west coast ports, does not touch Amapala. This portion of Honduras is broken by groups of volcanic cones, which gradually give place to lofty, well-timbered mountains with exuberant, growth-filled valleys, as the ranges back some miles from the coast are entered.

In these south-western highlands stands Tegucigalpa, the capital, situated in the centre of an amphitheatre of beautiful mountains, clothed far up their gently sloping sides with tangled growth, and in parts with the serried ranks of a coffee plantation. In the deep valleys, sugar-cane and cocoa are also largely grown, for this portion of the country, with the plateau farther inland, is the only populated region of the state, with the exception of a narrow strip on the Atlantic coast.

Tegucigalpa, famous not only as the capital of Honduras, but also as the birthplace of Morazan, who, like so many of the more enlightened Central Americans of his day, fell a victim in defence of the Union, has a population of about 35,000. It is a bizarre little town, composed of brightly painted bungalow-like houses, with but ill-paved streets, and few imposing buildings; but although grass grows in its less-frequented thoroughfares, and it has an indefinable atmosphere of quietude and contentment, it possesses a telephone system, a watersupply, and is about to have a cinematograph exhibition! There is neither a theatre nor a club, so that at present the cafés form the only social attraction. Its buildings, parks, and other attributes of a modern town are far behind those in the capitals of most of its neighbours. However, Tegucigalpa, the "City on the Silver Hill," is not to be despised, for it has historical tradition behind it, and, moreover, its people are ex- 


\section{SALVADOR AND HONDURAS}

ceptionally hospitable, and its mountainous surroundings are a pleasing combination of rocky grandeur and semi-tropical beauty.

"A clock on the cathedral tower marks the time, of which the inhabitants have a supply more than equal to the demand," as Mr Winter wittily puts it. In the small stream that divides the town women may be seen pounding all day at the dirty linen of Tegucigalpa.

The old capital of Honduras was Comayagua, a quaint little town situated on the central platcau, several leagues from Tegucigalpa. A fine old cathedral, battered and time-worn, and a statue of a Spanish king, are the only features of interest, except perhaps the inhabitants themselves, who are mostly half-breeds and Indians. The men have a sullen, indolent appearance, and are mostly to be seen lounging, while the women do the little work necessary to enable the family to live. The young girls, who are by no means repulsively ugly, have olive-tinted complexions, and black hair and eyes, which contrast picturesquely with the brightly embroidered shawls of native cloth, while the children are scarcely clothed at all. Some, perhaps, have a shirt, and others a pair of knickers, but few indeed possess a coat, or more than one garment to cover their little fat bodies; yet the nights are cool in these highlands, although the sun, during the day, blazes down with almost tropical fury.

Formerly the inhabitants of Comayagua numbered 30,000; but now only some 7000 live a life of dolce far niente among the sunlit orange groves. Its ancient churches, some of them mere roofless, ruined walls overgrown with moss and vines, remind us of the city's past; but the only interesting building is the fine old Spanish cathedral.

Off the Atlantic coast are a number of islands, known as the Bay Islands, one of which, Roatan, forty miles long by about three miles wide, with a population of 
3000 or 4000 , is a perfect Eden for the lazy man. The inhabitant of this terrestrial paradise has not even to climb a tree in search of the cocoanuts that grow there abundantly. In due course they fall at his feet, and to dress them the native has only to spike them on a sharpened stick. A piece of sugar-cane stuck in the ground will renew itself perennially, and it is " roses all the way," in this land whose eternal calm not even a revolution has disturbed.

Cassava bread, made from the tuberous root of the manioc; is one of the principal foods that support the native population of Caribs and mixed Indians and negroes called "Zambos," many of whom have now migrated to Nicaragua. The Caribs are considered the best sailors on the coast, and frequently venture out to sea on their dories; hewed from solid logs. They are an ingenious, friendly, and industrious race, much smarter in their dress, and with a higher opinion of themselves, than is the case with most natives. The life of the average native or half-breed on the higher lands is well summed up by Mr Winter:

"He lives from year to year in his thatched hut. He may look after a few cows and make cheese from their milk. He plants a small patch of maize each year and grows a few bananas and plantains for food. He is content to live on the plainest food and in the simplest way in order to live an indolent life. Thus he exists during his allotted years until he drops into his grave, and in a year or two there is not even a sign to show where he was laid."

The harbourof Puerto Cortez-formerly named Puerto Caballos, so called because Cortez lost so many horses there-is large, commodious, and safe. The blue waters of the bay, fringed with cocoanut-palms, and backed by great mountains, form a beautiful and typical Central American scene ; and if you are fort unate you may see there the navy of Honduras - originally a private yacht 


\section{SALVADOR AND HONDURAS}

-riding proudly at anchor, while her two guns, that might, or might not, be of service in war's alarms, point defiantly towards the open sea. Puerto Cortez is a small, undistinguished town of I200 or more inhabitants, somewhat subject to yellow fever, and for that reason often quarantined, sometimes for considerable periods. But the lowlands are being filled up, and the port, by the aid of steam dredgers and a good force of workmen, is being gradually converted into a good harbour. A system of modern sanitation, by depriving the yellow-fever mosquito of its breeding-places, would conduce largely towards the prosperity of the town.

Education, as might be expected, is in a very rudimentary condition throughout Honduras, and in the entire republic there are no more than about seven hundred schools for primary education. The wealthier families often send their boys to the university in Guatemala City, but the girls' schooling is not taken so seriously, and often they are left to shift for themselves. The principal amusement of the country is the amiable sport of cock-fighting, over which a considerable amount of money is yearly won and lost.

The climate and flora of Honduras vary in the same way as they do in all these states, although, perhaps, in an even more marked degree. Palms grow within a few leagues of wheatfields, and orange and lemon groves within sight of pineapples and bananas; while the bourgainvillæ, the hibiscus, the passion flower, the orchid, the wild rose, the ridge of pines, and the myrtle all flourish within the range of vision from one of the Io,000 feet-high mountains of the cordillera.

Honduras slopes gradually downwards, from the temperate, central plateau to the hot and damp bananalands and tropical forests of the Atlantic coast; but there are no mountains crowned with eternal snows, for the snow-line is high in Central America, and no 
peaks really touch it. On the lowlands there are swamps almost as pestiferous as those in the Lagos country.

To say that Honduras is a tropical country is to make an assertion which is easily questioned, for within its borders it is possible to live in almost any desired temperature; but, if the tierras tempiadas are chosen, the nights are cool, and the summer dust and winter mud are somewhat objectionabie, although the beautiful, warm, sunny days, during many months in the year, amply compensate for these disadvantages. But the tropical jungles of the moist, hot coast have all the fearsome creatures of their kind, including the fattest and most persistent mosquito to be found in the tropics. ${ }^{1}$ Here ague, malaria, and fevers are the drawbacks, and extreme fertility, gorgeous tropical growth, hot days, warm nights, and an aviary of birds of brilliant plumage are the atoning features. The upper slopes and lofty summits of the mountains are the health resorts of the country.

The tropical forests of Honduras are not less wonderful than those of other states of Central America. A journey among the manacca-palms, for example, the palm whose branches rise directly from the earth, and not from the top of a trunk, is an experience not to be forgotten. You pass beneath the natural archway of branches, sixty feet high, that bend and sway, and interlace themselves one with another in most graceful confusion. Before you the great leaves, some of them six feet broad, hang like a curtain, behind which each rider in turn disappears. Not a sound is heard, save the rustle and murmur of the forest, whose centuries of dead leaves muffle even the tread of the animals' hoofs.

The trunks of many of the larger trees are heavily buttressed, as we have described in the chapter on Guatemala; and some of their trunks are covered with

1 The mosquitoes in parts of Northern Siberia and in Alaska and the Yukon are, however, even more voracious: 


\section{SALVADOR AND IIONDURAS}

parasitic growths that suggest myriads of snakes crawling over the white surface. Orchids cling to the branches, and white-faced monkeys swing from trees, bending down by their weight the lighter boughs, until, released, they spring up again with a pleasant swish and rustle of moving foliage.

Travelling and transport in Honduras are almost entirely accomplished by pack-mules and ox-carts. The only public railway line in the country runs from Puerto Cortez on the Atlantic coast to San Pedro Sula and La Pimienta, a distance of only about seventy miles. This line is slowly being extended towards the Pacific coast, and a private railway some sixty miles in length operates among the vast banana plantations around $\mathrm{La}$ Ceiba on the north-east.

The Honduras railway, running from Puerto Cortez to Pimienta, is, on the whole, a poor affair. The trains, made up of a few coaches, and some open freight cars for the transport of bananas, run, with consistent irregularity, upon a line that has not been any too well constructed. In fact, the Government muddled the whole business, and some of the bonds issucd in respect of it were long the subject of international dispute. San Pedro Sula, the principal town on the line, is situate about thirty-eight miles from Puerto Cortez after a beautiful journey-of some four hours, if all goes well - through tunnels of palms and banana fields that might be called banana forests, to such a height do the bushes grow. The town lies in the lovely plain of the Sula, one of the most fertile in the country, and, thanks to the healing winds, one of the healthiest. San Pedro has another advantage to Europeans; and that is two fairly good hotels run by American managers.

Here it is that the traveller making for the capital will do well to provide himself with mules and the other necessaries of a journey through the wilds, for the road to Tegucigalpa is nothing more than a path winding 


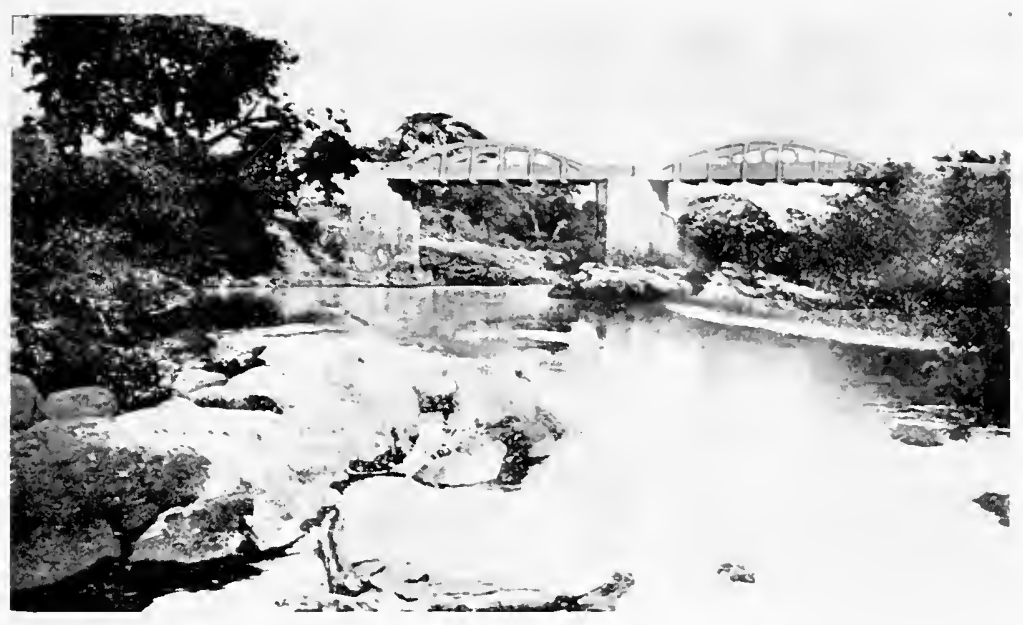

A River Scene in ". Sunny" Salvador

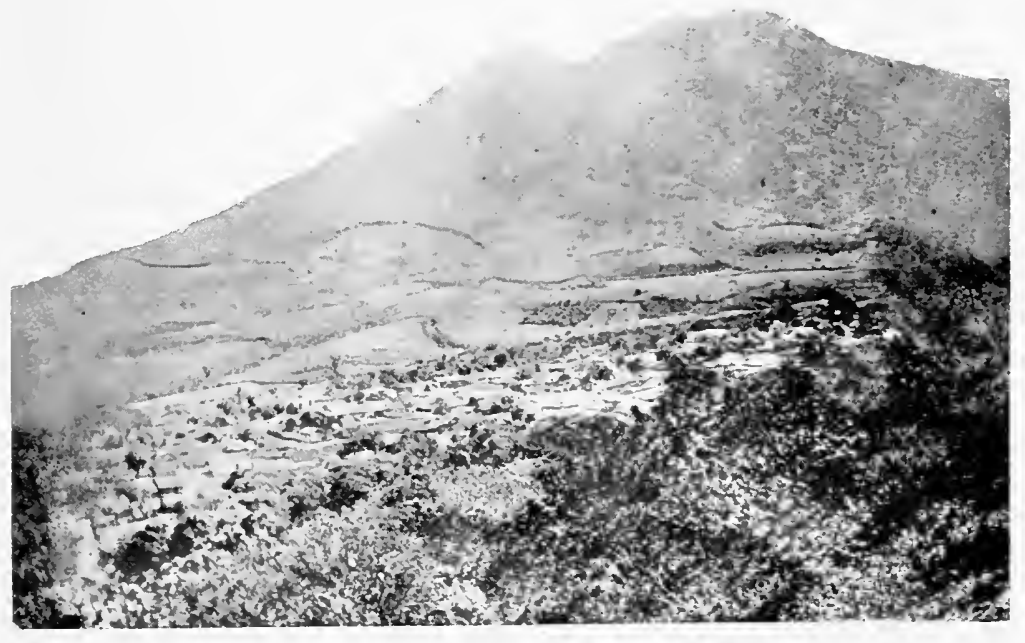

The Volcano of San Vicente y l'ueblo de Guadalupe, Salvador 



\section{HONDURAS}

through tropical forests, down the beds of streams, or along dizzy mountain ledges with the cliff above you and the gorge below. There are few inns, except the public cabildo, where the wayfarer can rest his weary bones; nor must he be surprised if he gains experiences such as this, described by Richard Harding Davis, in his "Three Gringoes in Venezuela " :

"I took an account of the stock before I turned in, and found there were three dogs, eleven cats, seven children, five men, not including five of us, three women and a dozen chickens, all sleeping, or trying to sleep, in the same room and under the one roof. And when I gave up attempting to sleep, and wandered out into the night, I stepped on the pigs, and startled three or four calves that had been sleeping under the porch, and that lunged up out of the darkness."

Other than the capital, there are few towns in Honduras worthy of the name, unless the titles of city and town are accepted in the Spanish-American sense, which, although yearly becoming less appropriate in such states as Argentina, Brazil, Chile, Peru, and Uruguay, must still be applied to all except a very few of the populous centres of Central America. The principal inland towns of Honduras are: Juticalpa, population about I8,000 ; Nacaome, I2,000 ; La Esperanza, II,453; Santa Rosa, Io,900; Choluteca, Io,800, and San Pedro Sula, 8000 .

There is, however, another, Copan-a city of the dead - which lies near the Guatemala frontier in the midst of hills covered to their summits with a luxuriance of gorgeous tropical vegetation and forest. This once great Indian city, of an age far back in history, and a primitive civilisation so unlike that which once appertained in Europe, or even in the marvellous East, is now a mass of wide terraces, broad stone steps, and massive, carved monuments on which, in bold relief, can still be deciphered the hieroglyphics of a bygone 


\section{SALVADOR AND HONDURAS}

time and people, and the scowling features of figures apparently representing high priests, so well calculated are they to infuse the terror of the unknown which formed the foundation of many of the early religions. Stone columns, half buried in tangled growth, fragments of sculptured stone, weed-choked terraces, and still perfect, massive stone steps, all are there, but time-worn, and hidden deep in the chaotic growth of the tropics.

Weirdly impressive and mysterious are these carved monuments in the plaza, amidst their setting of undergrowth, and of hills sparsely clothed with pine-trees. Around them rise great mounds, ${ }^{1}$ and stone staircases, hoary and moss-grown, twisted and broken by great roots of trees, old almost as they. Here, in huge square masses, stand the stones deeply carved with profusion of ornament, with human figures, with grotesque animals, with diabolic imps, with scrollwork and feather-work, so skilfully done that one marvels that no implements more elaborate than stone axes have ever been found among the ruins.

Stephens' description of Copan may well find a place here :

"Of the moral effects of the monuments themselves, standing as they do in the depths of a tropical forest, silent and solemn, strange in design, excellent in sculpture, rich in ornament, different from the works of any other people, their uses and purposes, their whole history so entirely unknown, with hieroglyphics explaining all, but perfectly unintelligible, I shall not pretend to convey any idea. Often the imagination was pained in gazing at them. The tone which pervades the ruins is that of deep solemnity. An imaginative mind might be infected with superstitious feelings. From constantly calling them by that name in our

${ }^{1}$ The mounds are bases for the temples that have been erected on them, at various dates: 
intercourse with the Indians, we regarded these solemn memorials as 'idols'-deified kings and heroesobjects of adoration and ceremonial worship. We did not find on either of the monuments or sculptured fragments any delineations of human or, in fact, of any other kind of sacrifice, but had no doubt that the large sculptured stone invariably found before each 'idol' was employed as a sacrificial altar. The form of sculpture most frequently met with was a death's head, sometimes the principal ornament and sometimes only accessory; whole rows of them on the outer wall adding gloom to the mystery of the place, keeping before the eyes of the living, death and the grave, presenting the idea of a holy city-the Mecca or Jerusalem of an unknown people."

To determine the exact age of these silent monuments of a dead race is beyond the power of all but a student of ancient archæology. Like the Incas' ruins at Cuzco, on the Transandean tableland in Peru; the great mountain road in the almost inaccessible sierra of Columbia, Bolivia, and Peru; the remains on the island-birthplace of Capac on far-off Lake Titicaca; the fourteen-feet-high stone figures on remote Easter Isle, far out on the bosom of the Pacific; the remains in Nicaragua and those in Guatemala and Mexico-from which might be deduced, if all were studied together, a fairly accurate story of the early empires of South and Central America, of which we at present know so little-they still remain, notwithstanding the recent praiscworthy and valuable efforts which have been made to pierce the veil, one of the great mysteries of the past.

The Atlantic slope of Honduras differs little from the mosquito coast of Nicaragua, with the exception that it is fringed by numerous tropical islands in the shallow bay of Honduras, and from its beginning at Cape Gracias à Dios, throughout its entire length 


\section{SALVADOR AND HONDURAS}

to the Guatemalan frontier, it faces north towards Cuba.

It is par cxcellence a land for the cultivation of bananas and other tropical fruits, and shows unmistakable signs of mineral wealth, but like all mosquititia-of which it is merely an extension-it suffers from a humid and feverish climate.

The republic of Honduras must, however, in no way be confused with British Honduras, to which it is not even joined, the latter Crown colony being situated higher up the isthmus, bordering Guatemala and Mexico.

The Atlantic ports of Honduras may be summed up in a few words, for they are little more than anchorages. The chief is Puerto Cortez, a small town of bungalow-like appearance with about 2500 inhabitants, which is the rendezvous of Mexican cattleboats; Omoa, the tiny port of the inland town of San Jago and the sparsely populated north-west district, has only Iooo inhabitants; Truxillo, at one time the principal port on this coast, and the one on which William Walker made his famous last raid, has a population of less than 300o, but exports large numbers of cattle, to Havana and other ports in Cuba; while from Roatan fruit is extensively exported during certain months in the year.

Agriculture and cattle-breeding form the two most important industries in Honduras, although there are various local crafts, such as the weaving of Indian cloth, the plaiting of straw hats, and the fashioning of crude pottery, while the native women are clever at embroidering. But this state, as a whole, is sorely behind times with modern manufactures, even of the simplest necessities of civilised life; and the mineral resources, great as they undoubtedly are, have been but little exploited since the Spanish colonial days.

The cultivation of bananas and cocoanuts on the 
Atlantic coast has assumed such giant proportions, during quite recent years, that these fruits now form the chief export of the country, the average annual shipment amounting in value to about $£ 200,000$. Coffee is still largely grown in the highlands and on the plateau, but the difficulty experienced by the planters in obtaining sufficient labour during the picking seasons, and the enormous output from the state of Sao Paulo, Brazil-the great rival of all coffee-growing countriesappears to be checking the further cultivation of this crop. Yet the export is fairly large, amounting in value to nearly $£$ Ir,ooo per annum.

The production of rubber is rapidly on the increase. The vast forests in this state literally teem in places with these trees, which, until recently, have been left quite uncared for. The value of the annual export of rubber now averages about $£ 7000$. Sugar is also largely grown in Honduras, but the output supplies only the home demand, and that required for the extensive manufacture of rum, very little indeed being exported.

Oranges and lemons are grown in appreciable quantities, and find their way principally to the United States; while indigo, rice, tobacco, wheat, maize, and beans are also grown in small quantities, principally for home consumption. Only a tithe of the fertile land available in this large state has ever been broken for agricultural purposes. Thousands of acres are still available for the planter with a moderate capital.

About 200,000 acres of land in Honduras are used for grazing purposes. There are, in this state, nearly 300,000 head of cattle; 64,200 horses; 13,500 mules ; 13,000 pigs, and 24,000 sheep. ${ }^{1}$ The export of cattle to Mexico, Cuba, and the surrounding states is undoubtedly fairly large, but no exact statistics are available.

${ }^{1}$ Reasonable additions and deductions have been made to bring official statistics issued in I909 up to date. 


\section{SALVADOR AND HONDURAS}

The vast cedar and mahogany forests are being scientifically worked, and the export of these woods is very considerable, but the mineral resources hereabouts appear to go begging. Platinum, gold, silver, copper, lead, zinc, iron, and nickel are all known to cxist ; but, with the solitary exception of an American silver mine, which is yearly increasing its output, little is being done, except by native syndicates with crude machinery, to locate or work these deposits. This, however, is partly accounted for by the absence of roads and the almost total lack of means of transport in the intcrior, the want of capital and skill, and the unhealthy elimate of large tracts of country in the lowlands.

Although Honduras is six times as large as Salvador, and has a fertility of soil and richness of mineral deposits apparently far superior to those of its tiny neighbour, the value of its foreign commerce, owing almost entirely to the sparseness of the population, is much less, as will be seen from the following table :-

Foreign Commerce of the Republic of Honduras

\begin{tabular}{ccc} 
Year & Imports & Exports \\
\hline 1908-I909 & $£ 5$ I 6,5 I I & $£ 405,776$ \\
I909-I910 & $£ 53$ I,750 & $£ 494,592$
\end{tabular}

The chief imports are cotton goods and provisions, and the exports, bananas, cattle and hides, coffee, rubber, gold and bar-silver. The bulk of the trade is with the United States.

Until I908-I909, the revenue of Honduras was for several years less than the expenditure, notwithstanding the fact that the country was heavily in debt, both at home and abroad, and that no interest had been paid on the foreign loans for nearly forty years.

The financial position of this state is best shown in 
tabular form. The Hondurean silver peso is reckoned at the rate of thirteen to the pound sterling.

\section{Revenue and Expenditure}

\begin{tabular}{cccc} 
Year & Revenue & Expenditure & $\begin{array}{c}\text { Excess of Expenditure } \\
\text { over Revenue }\end{array}$ \\
\hline I906-I907 & $£ 244,142$ & $£ 357,903$ & $£$ I I 3,76 I \\
I907-I908 & $£ 299,945$ & $£ 323,538$ & $£ 23,593$ \\
I908-I909 & $£ 269,478$ & $£ 269,478$ & $\ldots$ \\
I909-I910 & $£ 362,620$ & $£ 362,620$ & $\ldots$ \\
I910-I9I I & $£ 362,620$ & $£ 362,620$ & $\ldots$
\end{tabular}

These figures are certainly curious, as not only does the revenue and expenditure during the last three years balance exactly, but also the receipts in Igog-I9ro and I9IO-rgII.

However, these figures, incredible as they certainly are, must be assumed to be correct, for lack of evidence to the contrary.

As in nearly all these states, the revenue is principally derived from customs and monopolies (spirits, tobacco, and powder), while a considerable portion of the expenditure is for administration and internal developments. In I9II a treaty was entered into with the United States, whereby that country became more or less concerned in the financial reorganisation of Honduras. This was, doubtless, primarily brought about by the deplorable economic position of the country, and the repeated failure to pay the interest on the foreign loans.

The external debt of Honduras in rgro amounted to $£ 5,398,570$, with interest in arrears amounting to the enormous sum of $£ \mathrm{r} 7,07 \mathrm{I}, 940$. The foreign loans are four in number, all contracted during those ten years of civil warfare and stagnation between I860 and I870, while the interest which became due was paid for only two years. Since $I \delta 72$ no interest had been paid on the foreign loans of Honduras. 


\section{CONCLUSION}

ACRoss the impressions, facts, and figures accumulated in this book, the five states of Central America will be seen as young countries just awakening from their long sleep. A brightening dawn is rising from the east, only, however, to disclose the spectres of the past menacing the future.

Many and dark have been the years of revolution, adventure, and happy-go-luckydom. Sanguinary nation makers and breakers have been the order rather than the exception, and cunning statesmen, who fought for power, that in the brief space of its enjoyment they might fill their coffers, and retire gracefully over the frontier, have often been the leaders of these peoples, and the cause of their financial degradation. Well may these nations cry: "Oh, Liberty! Liberty! how many crimes are committed in thy name!" 1

Although the dawn has broken at last, all is not yet well in Central America-how could it be otherwise after a century of strife? But in the rapidly strengthening light of day these nations are rising with an eagerness which compels attention, and a proper appreciation of their possibilities and responsibilities; yet, being but half educated, they imagine themselves wise; they will accept but little guidance; and, when forced, take refuge in " mañana-land."

The past is often the enemy of the future. Now, when close on a hundred years have clapsed since they proclaimed their freedom, the people of this portion of

1 Madame Roland, on the scaffold. 
the continent are beginning to tread warily in the footsteps of the rising nations of South America, who in their day followed the empires of the North; only, however, to find themsclves confronted with three stern foes : a scanty, apathetic populace; a reputation, in the world's financial and commercial circles, for revolutions and instability; and climate and conditions generally unsuitable for immigrant labour from North Europe.

But the time has come when the two former enemies no longer count. No more can ignorance foster erroneous conceptions, for railways are being pushed across the isthmus in all directions; a canal, which will become one of the most important, and most frequented, waterways in the world, is cutting the continent in two on the borders of these states; the natural ties of language, custom, and mutual benefit, although delayed again and again, and probably only now on the brink of fulfilment, are slowly welding them into a union, the affixing of political seals to which is but a matter of time and circumstance.

The rising home and foreign commerce and trade are good and sound omens of the future, and the hope expressed on all sides, in some of these states, that, in the near future, they may be able to set their financial house completely in order, is a sign of the changing times.

Yet much remains to be done before the states of Central America can take their proper place among the nations of the world. Of these future labours nothing can be here said, for they are the hundred and one things so vitally necessary in the making or regeneration of nations.

Will Great and Greater Britain realise the future possibilities of Central America before it is too late, or will she leave these lands to the United States and Germany, who have now a footing far stronger here 
than they ever had in South America during the period of transition?

Many excuses may be put forward for this lack of enterprise; but the fact remains that, in Central America, the Empire is throwing away a market, a field for investment, a zone of increasing political importance, because of the refusal of her people to believe that past conditions in these countries are fast passing away, that property, personal rights, and commerce are as safe there as in South America, or elsewhere in the world; that these lands, which go uncared for, are as rich as those which are scrambled for elsewhere; and lastly, but in excelsis, that the unrest and corruption which made progress impossible in the past are no longer a menace to the future.

Tempori parendum. 


\section{Works by the Same Author}

\section{THE UNITED STATES OF BRAZIL}

With a Chapter on Uruguay

Profusely Illustrated. Demy 8vo. r2s. 6d. net

\section{PRESS OPINIONS}

"In 'The United States of Brazil' Mr Domville-Fife has produced a book which should appeal to those interested in the country he describes. ... All the States and all the chief cities are faithfully described, together with their industries and customs; and the problems which the country has to solve are set forth temperately and clearly."-The Times.

"Mr Domville-Fife's descriptions of people and scenery are often excellent."-Westminster Gazette.

"Though the author in his preface speaks very modestly of his qualifications for his self-imposed task any apology is unnecessary, for in the brief compass of $25^{\circ}$ pages he has managed to give his readers a comprehensive account of the history, position and prospects of what is potentially the most important country of South America."-Morning Post.

"Having previously written to good purpose on 'The Great States of South America,' Mr Domville-Fife had ample credentials to warrant such a large enterprise as that which is involved in an exhaustive discussion of the Brazils."-Glasgow Herald. 


\section{SUBMARINES OF THE WORLD NAVIES}

Illustrated with 100 Photographs showing Submarines in Peace and War

\section{PRESS OPINIONS}

"Mr Domville-Fife may be congratulated on the successful compilation of a most useful addition to the list of practical works on Naval Engineering, Strategy and Sea Power."-The Outlook.

"This is perhaps the most complete work upon this branch of Naval Science that has yet been published."-Times.

"It cannot help but interest any reader who follows naval affairs."-Daily Nezes.

"Submersible vessels of war are little understood by the general public, and the present work by an authority of the standing of Mr Charles Domville-Fife should do much to dispel the growing suspicion of the value as compared with the dangers of this class of warship."-Liverpool Daily Post.

"To write a book on Submarines in view of the secrecy with which all nations guard the construction and internal working of such craft is no easy matter if the book has to be more than a mere theoretical discussion of their value in warfare. To illustrate it in anything like a full manner is still more difficult. Yet in the present volume we find both these objects fully and ably accomplished. It is obvious that the author knows his subject; at times we can almost feel certain that he has had access to a considerable amount of inside and exclusive information."-The Engineer.

"To the student of naval affairs and also to the general public who takes an interest in such matters, we can cordially recommend this book."-Pall Mall Gazette. 


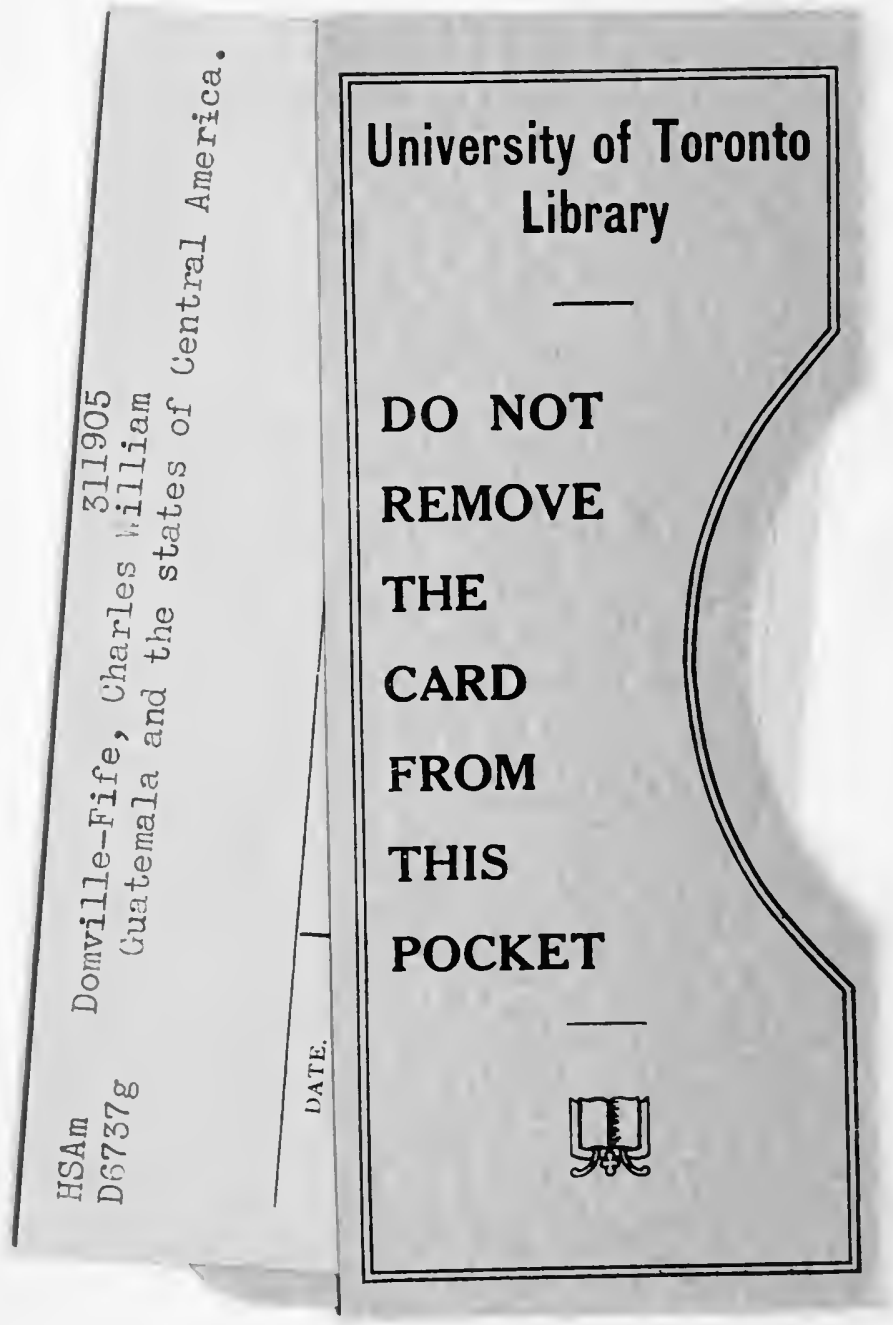




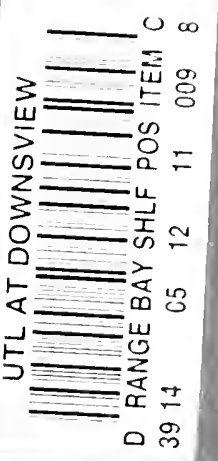

